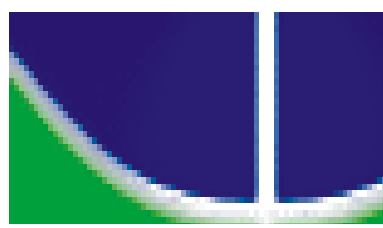

UNIVERSIDADE DE BRASÍLIA

INSTITUTO DE GEOCIÊNCIAS

A QUALIDADE DOS RECURSOS HÍDRICOS SUPERFICIAIS NO ALTO CURSO DA BACIA HIDROGRÁFICA DO CÓRREGO CAMPO ALEGRE - GOIÁS

\author{
JÉSSICA DE SÁ GUIMARÃES PEIXOTO
}

Dissertação de Mestrado $\mathbf{n}^{0} 073$ 


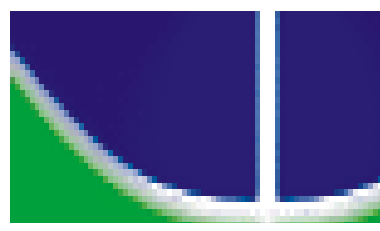

UNIVERSIDADE DE BRASÍLIA INSTITUTO DE GEOCIÊNCIAS

\title{
A QUALIDADE DOS RECURSOS HÍDRICOS SUPERFICIAIS NO ALTO CURSO DA BACIA HIDROGRÁFICA DO CÓRREGO CAMPO ALEGRE - GOIÁS
}

\author{
JÉSSICA DE SÁ GUIMARÃES PEIXOTO
}

Dissertação de Mestrado $\mathbf{n}^{0} 73$

Orientador:

Prof. Dr. Luciano Soares da Cunha- IG/UnB

Examinadores:

Prof. Dr. Jérémie Garnier - IGD/UnB Examinador Interno

Prof. Dr. Rogério Elias Soares Uagoda - GEA/UnB Examinador Externo 


\section{DEDICATÓRIA}




\section{AGRADECIMENTOS}

Em primeiro lugar agradeço a Deus, por me conceder saúde e capacidade de aprendizado permitindo-me concluir mais essa importante etapa de minha vida;

Ao professor Dr. Luciano Soares da Cunha, pelo crescimento intelectual, senso prático e aprendizado durante a execução da pesquisa;

Em especialmente ao prof. Dr. José Elói que desde o início se mostrou prestativo, prudente e competente como professor e coordenador, sendo indispensável no êxito deste trabalho;

Aos demais professores do IG, por meio de ensinamentos foram capazes de enriquecer e amadurecer meus conhecimentos.

Aos técnicos do Laboratório de Geoquímica da UnB, Myller e Fernando pelo auxílio nas análises geoquímicas das amostras e esclarecimento de dúvidas;

A Capes e ao Instituto de Geociências pelos auxílios financeiros essenciais à execução e divulgação deste projeto.

A minha mãe meu maior exemplo, pelo amor, paciência e incentivo ao concluir este trabalho, pelo irmão amado pela franqueza e motivação durante as dificuldades e ao meu namorado Alexandre por sempre acreditar no meu potencial, pela atenção, carinho e respeito na concretização dos meus sonhos.

Aos membros da banca examinadora, pela presença, disponibilização de tempo e, especialmente pelas imprescindíveis contribuições.

A minha amiga Cristiane que esteve comigo nessa jornada me oferecendo força, companheirismo, conselhos e contribuição nesse trabalho, a Vanessa, Érica, Leila, Guilherme, Alice, Eudes e a todas as pessoas e instituições que, de alguma forma, contribuíram para o aprimoramento e finalização desta Dissertação.

A todos, muito obrigado! 


\section{RESUMO}

Neste trabalho foi realizado o estudo geoquímico da bacia hidrográfica localizada no alto curso do córrego Campo Alegre. Teve como objetivo analisar a qualidade da água superficial do Córrego Campo Alegre, utilizada para abastecimento público, a partir de parâmetros químicos e concentração de metais nos sedimentos para identificação das principais fontes dos elementos, distinguindo-os em geogênico, pedogênico e antropogênico. A bacia do Córrego Campo Alegre localiza-se no município de Campo Alegre de Goiás, na bacia hidrográfica do Rio Veríssimo, na sub-bacia do sul do Rio Paranaíba. O contexto geológico da região é constituído pelos grupos Ibiá, e Araxá, e a Sequência vulcano-sedimentar do Rio Veríssimo, todos recobertos por latossolos ricos em laterita. Para a determinação das amostras de água foi utilizado técnicas de espectrometria de emissão ótica com plasma indutivamente acoplado (ICP/OES), espectrometria de Absorção Atômica (AAS), cromatografia iônica (IC) com condutividade suprimida e métodos volumétricos. A abertura das amostras de sedimento (fração $<63 \mu \mathrm{m}$ ) foi realizada por meio de fusão para elementos maiores e ataque ácido para traços. A determinação dos elementos utilizou técnicas de ICP/OES e a determinação dos minerais utilizou DRX. A interpretação dos resultados utilizou análises estatísticas multivariadas como: análise de principais componentes, agrupamento hierárquico e índice de geoacumulação. Os parâmetros físico-químicos da água e, também, os elementos químicos analisados em água e sedimentos, apresentaram valores dentro da normalidade segundo CONAMA 357/05 para rios de classe II. Para os valores de metais em água, não houve valores expressivos de alteração da qualidade da água nos períodos sazonais. As maiores contribuições foram oriundas de detergentes e sabão em usos domésticos $(\mathrm{NaCl})$, principalmente em pontos dentro do perímetro urbano e a utilização de fertilizantes na agricultura.Com o emprego das técnicas estatísticas aplicadas foi possível identificar os principais processos de modificação da qualidade da água do Córrego Campo Alegre, possibilitando identificar a origem em pedogênico e antropogênico dos parâmetros analisados. Notou-se que no período seco os parâmetros são menos abundantes que amostras da estação chuvosa, comportamento ocasionado pelo escoamento superficial que carreiam metais e partículas de diversas interferências antrópicas para o ambiente aquático. Com a análise mineralógica e o índice de geo-acumulação, permitiu distinguir, de forma multi-elementar, as diferentes influências ocasionadas pelos depósitos minerais no acúmulo de metais nos sedimentos do córrego. As características mineralógicas foram apresentadas, através das análises no Raio-X, identificando o quartzo, como componente principal e a caulinita, 
goethita, gibsita, rutilo. E os índices de geoacumulação apresentaram valores baixos, classificados os sedimentos da região em sua maioria, como não poluídos a moderadamente poluídos. Foram estabelecidos valores de referência, com o intuito de acompanhar as transformações ocorridas no interior desta bacia. Apesar de indícios de interferência da agricultura o Córrego Campo Alegre ainda apresenta um sistema em equilíbrio. 


\begin{abstract}
This paper represents the geochemical study of the basin located in the upper reaches of Campo Alegre stream. It aimed at analyzing the quality of the surface water of Campo Alegre stream used for public supply from chemical parameters and concentration of metals in sediments for identifying the major sources of the elements, distinguishing them in geogenic, pedogenic and anthropogenic features. The basin of Campo Alegre stream is located in Campo Alegre de Goiás, in the basin of Veríssimo River, in the sub-basin south of Parnaíba River, consisting of Ibiá, Araxá, Canastra groups and the volcano-sedimentary sequence of Veríssimo River, covered with red soils rich in laterite. The determination of water samples used optical emission spectrometry techniques with inductively coupled plasma (ICP/OES), Atomic Absorption spectrometry (AAS), ion chromatography (IC) with suppressed conductivity and volumetric methods. The opening of a sediment sample (fraction $<63 \mu \mathrm{m}$ ) was performed by fusion for larger elements and for etched features. ICP/OES was used for element determination and XRD, for mineral determination. Multivariate statistical analyzes such as principal component analysis, hierarchical clustering and geoaccumulation index were used for interpretation of the results. The physical and chemical parameters of the water and the chemicals analyzed in water and sediment had values within normalcy according to CONAMA 357/05 for class II. In the amounts of water on metals, no significant amounts of change in water quality in the seasonal periods The largest contributions were coming from detergents and soap in domestic uses $(\mathrm{NaCl})$, especially at points within city limits, and the use of fertilizers in agriculture .With the use of the applied statistics techniques, it was possible to identify the main processes for modifying the water quality of Campo Alegre stream, making it possible to identify the origin as pedogenic and anthropogenic of the parameters analyzed. One noted that in the dry season the parameters are less abundant than samples of the rainy season, behavior caused by runoff that carries metals and particles of various anthropogenic interference to the aquatic environment. With the mineralogical analysis and the geo-accumulation index, it allowed distinguishing, in a multi-elemental form, the different influences caused by mineral deposits in the accumulation of metals in stream sediments. The mineralogical characteristics were presented throughout the analysis in X-ray, identifying the quartz as a main component and kaolinite, goethite, gibbsite, rutile. And geoaccumulation indices showed low values, being the sediments of the region ranked mostly as unpolluted to moderately polluted. Reference values were established in order to monitor
\end{abstract}


changes within this basin. Although there are indications of agriculture interference, Campo Alegre stream still has a system in equilibrium. 


\section{SÚMARIO}

RESUMO

ABSTRACT

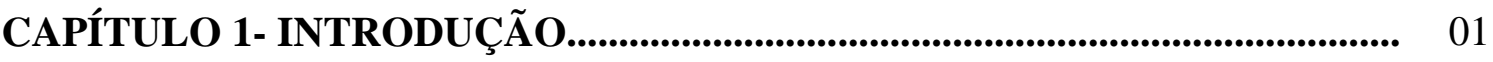

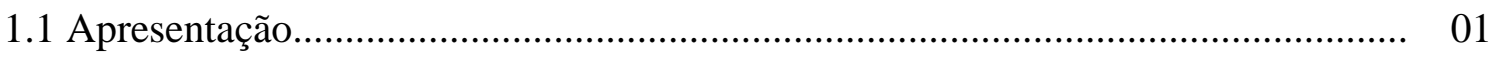

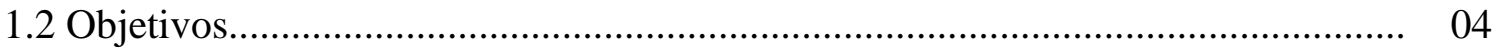

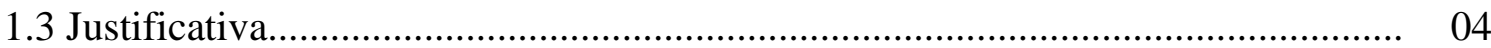

CAPÍTULO 2-ASPECTOS FISIOGRÁFICOS.................................................... 06

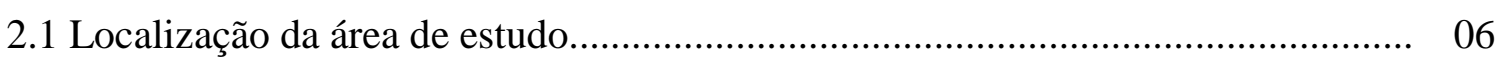

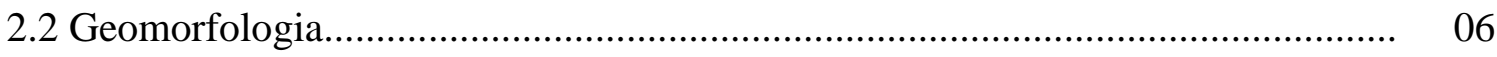

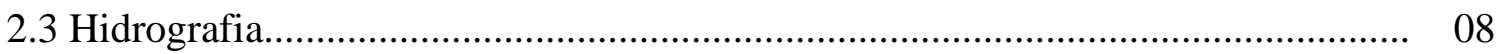

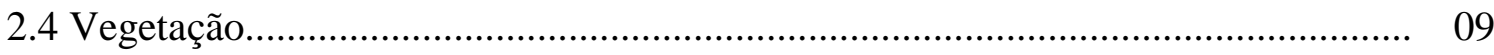

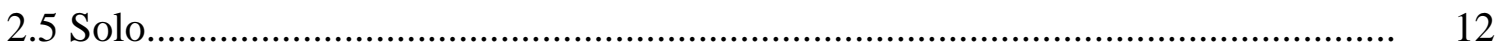

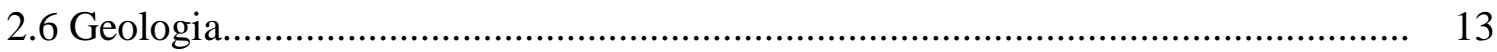

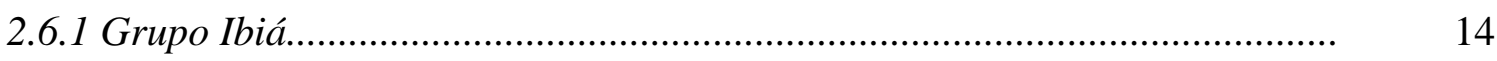

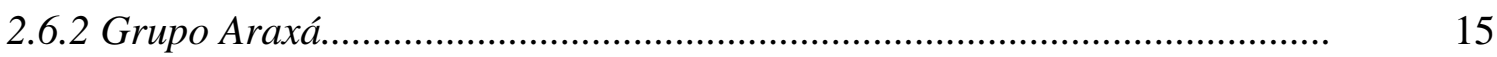

CAPÍTULO 3- BASES CONCEITUAIS ...................................................... 17

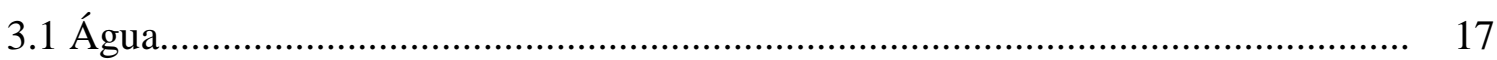

3.2 Bacia Hidrográfica e Microbacias....................................................................... 19

3.3 Índices Geoquímicos.................................................................................. 22

3.4 Fontes dos Elementos Químicos....................................................................... 24

3.5 Elementos-Traço no Meio Ambiente.................................................................... 26

3.6 Influência das Atividades Antrópicas sobre a Qualidade de Água....................... 27

3.7 Intemperismo

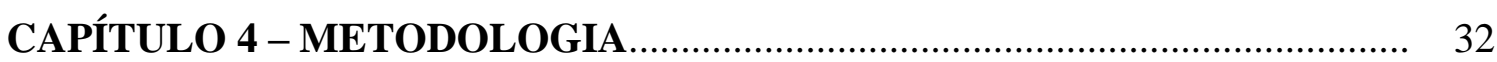

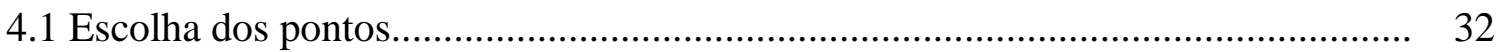

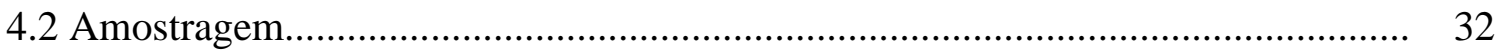

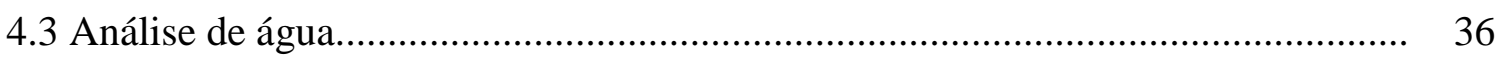

4.3.1 Determinação de parâmetros físico-químicos................................................... 36

4.3.2 Determinação dos ânions............................................................................... 36 
4.3.3 Determinação dos metais em água................................................................. 37

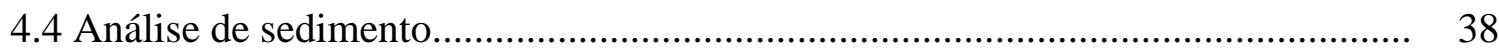

4.4.1 Decomposição das amostras......................................................................... 38

4.4.2 Determinação dos metais em sedimento......................................................... 39

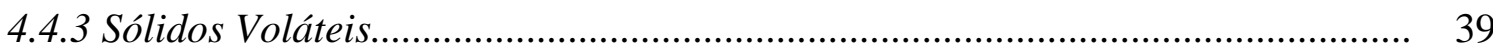

4.4.4 Análise mineralógica por Difratometria de raio-X.......................................... 39

4.5 Controle Analítico dos dados........................................................................... 40

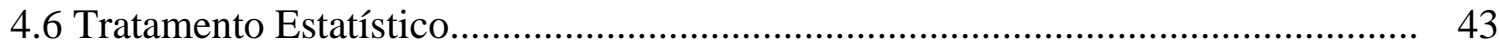

4.6.1 Análise de Componentes Principais................................................................ 44

4.6.2 Análise de Grupos (Cluster Analysis)........................................................... 45

4.6.3 Índice de geoacumulação ................................................................................ 45

CAPÍTULO 5- RESULTADOS E DISCUSSÃO ............................................... 47

5.1 Análise das amostras de água........................................................................ 47

5.1.1 Potencial Hidrogeniônico, Alcalinidade e $\mathrm{CO}_{2}$........................................ 47

5.1.2 Condutividade Elétrica, Total de Sólidos Dissolvidos, $\mathrm{Ca}, \mathrm{Mg}, \mathrm{Na}, \mathrm{K}, \mathrm{Cl}^{-}$e $\mathrm{NO}_{3}^{-}$

5.1.3 Cátions e Ânions............................................................................... 50

5.2 Classificação das águas.............................................................................. 56

5.3 Análise Multivariada dos dados geoquímicos..................................................... 59

5.4 Resultados Sedimentos.............................................................................. 62

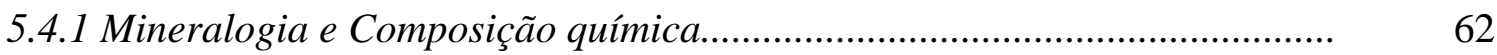

5.4.2 Matriz de Correlação................................................................................. 67

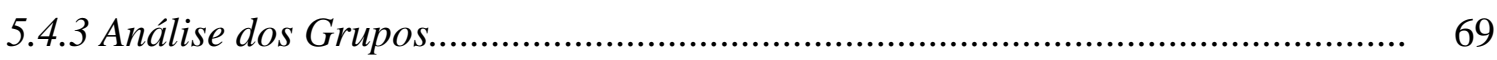

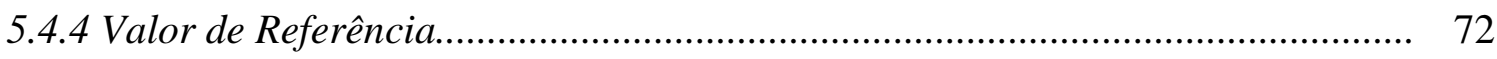

5.4.5 Índice de Geoacumulação............................................................................... 73

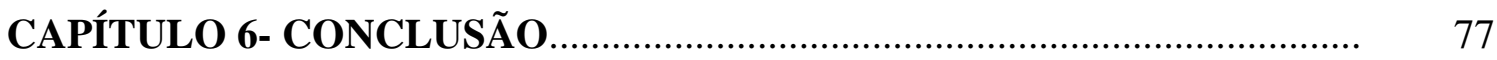

CAPÍTULO 7- REFERÊNCIAS BIBLIOGRÁFICAS........................................ 79

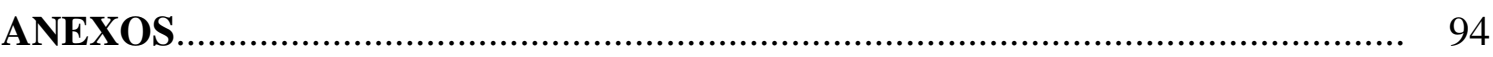

Anexo 1- Resultados dos parâmetros físico-químicos nas amostras de água do

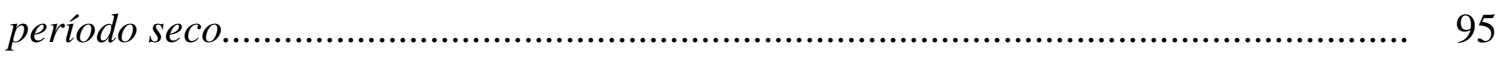


Anexo 2- Resultados dos parâmetros físico-químicos nas amostras de água do período chuvoso.

Anexo 3-Resultados da Análise de Sedimento de Fundo (óxidos) e Sólidos Voláteis (\%).

Anexo 4- Resultados da Análise de Sedimento de Fundo dos Elementos- Traço $(m g / L)$. 96

Anexo 5: $I_{\text {geo }}$ Calculado para Óxidos $(m g / L)$ 97

Anexo 6: I Igeo Calculado para Elementos- Traço $(\mathrm{mg} / \mathrm{L})$.......................................... 97

Anexo 7: Difratogramas obtidos nas análises mineralógica.................................... 98

Anexo 8: Análise Principais Componentes- Água-Estação Seca............................... 105

Anexo 9: Análise Principais Componentes- Água- Estação Chuvosa......................... 105

Anexo 10: Análise Principais Componentes- Sedimento- Estação Seca..................... 106

Anexo 11: Balanço iônico- Água- Estação Chuvosa................................................... 107

Anexo 12: Balanço iônico- Água- Estação Seca....................................................... 108 


\section{LISTA DE FIGURAS}

FIGURA 2.1 Mapa de localização da área de estudo.

FIGURA 2.2 Mapa Geomorfológico e Hidrogeológico da área de estudo.

FIGURA 2.3 Mapa de uso do solo e coberta vegetal da área de estudo.................. 11

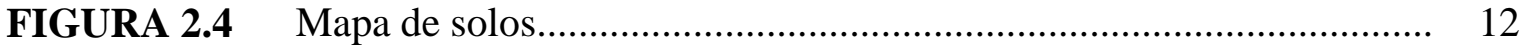

FIGURA 2.5 Mapa Geológico da área de estudo..................................................... 16

FIGURA 4.1 Mapa de pontos de coleta de água e sedimento................................ 33

FIGURA 4.2 Diferentes aspectos dos locais de coleta........................................... 35

FIGURA 4.3 Espectrômetro de Emissão Atômica com Plasma Indutivamente Acoplado (ICP/AES) ............................................................... 37

FIGURA 4.4 Procedimento para abertura ácida das amostras de sedimento............ 38

FIGURA 4.5 Etapas realizadas de fusão de amostras de sedimento......................... 39

FIGURA 5.1 Valores de $\mathrm{pH}$ das águas do córrego Campo Alegre nas estações seca e chuvosa, de montante para jusante.

FIGURA 5.2 Concentração da alcalinidade total nas águas durante os períodos da seca e da chuva, de montante para jusante do córrego Campo 48 Alegre.

FIGURA 5.3 Valores de condutividade elétrica $(\mu \mathrm{S} / \mathrm{cm})$ das águas do córrego Campo Alegre nas estações chuvosa e seca.....

FIGURA 5.4 Bloxplot dos cátions e ânions para todos os pontos na estação seca...

FIGURA 5.5 Bloxplot dos cátions e ânions para todos os pontos na estação chuvosa.

FIGURA 5.6 Matriz Scatterplots entre os parâmetros em amostras de água do Córrego Campo Alegre na estação seca.

FIGURA 5.7 Matriz Scatterplots entre os parâmetros em amostras de água do Córrego Campo Alegre na estação chuvosa

FIGURA 5.8 Diagrama de piper para amostras de água do Córrego Campo Alegre referente ao período seco

FIGURA 5.9 Diagrama de piper para amostras de água do Córrego Campo Alegre referente ao período chuvoso.

FIGURA 5.10 Agrupamento dos parâmetros na APC (PC1 x PC2) na estação 
seca

FIGURA 5.11 Agrupamento dos parâmetros na APC (PC1 x PC2) na estação

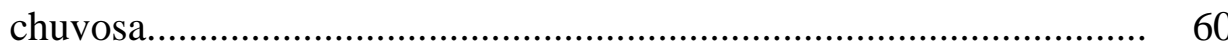

FIGURA 5.12 Difratograma dos minerais mais comuns na área de estudo (Ponto1). 62

FIGURA 5.13 Agrupamento dos elementos de sedimento de fundo utilizando Análise de Componentes Principais.................................................. 69

FIGURA 5.14 Dendograma dos resultados de amostras de sedimento de fundo........ 72 


\section{LISTA DE TABELAS}

TABELA 4.1 Pontos de amostragem no córrego Campo Alegre............................. 34

TABELA 4.2 Resultados obtidos para o padrão ION915........................................ 41

TABELA 4.3 Resultados obtidos para o padrão PERADE....................................... 41

TABELA 4.4 Controle de qualidade do padrão C - basalto..................................... 42

TABELA 4.5 Resultados estatísticos relevantes e figuras de mérito obtidas pela análise de 5 curvas de calibração independentes lidas em 3 dias diferentes

TABELA 4.6 Classes do Indice de geo - acumulação.............................................. 46

TABELA 5.1 Resultados dos elementos químicos na água do Córrego Campo Alegre.

TABELA 5.2 Resultados dos elementos maiores e sólidos voláteis nos sedimentos de fundo do córrego Campo Alegre

TABELA 5.3 Correlação de Pearson para os sedimentos de fundo da área em estudo.

TABELA 5.4 Valores de background estabelecidos em diferentes estudos.......... 73

TABELA 5.5 Classificação do Índice de Geo - acumulação................................... 74

TABELA 5.6 Referência geoquímica para as concentrações de sedimentos no córrego Campo Alegre 


\section{LISTA DE SIGLAS}

$\begin{array}{ll}\text { ANA } & \text { Agência Nacional das Águas } \\ \text { APHA } & \text { American Public Health Association } \\ \text { APC } & \text { Análise de Componentes Principais } \\ \text { APP } & \text { Áreas de Preservação Permanentes } \\ \text { CE } & \text { Condutividade Elétrica } \\ \text { CETESB } & \text { Companhia Estadual de Tecnologia e Saneamento Básico } \\ \text { DRX } & \text { Difratometria de Raio-X } \\ \text { EAA } & \text { Espectrofometria de Absorção Atômica } \\ \text { EMBRAPA } & \text { Empresa Brasileira de Pesquisa Agropecuária } \\ \text { FA } & \text { Fator de Acumulação } \\ \text { FC } & \text { Fator de Contaminação } \\ \text { IBGE } & \text { Instituto Brasileiro de Pesquisa Estatística } \\ \text { IC } & \text { Cromatógrafo Iônico } \\ \text { ICP- OES } & \text { Espectrometria de emissão óptica por plasma acoplado indutivamente } \\ \text { Igeo } & \text { Índice de Geoacumulação } \\ \text { LAGEQ } & \text { Laboratório de Geoquímica } \\ \text { LD } & \text { Limite de Deteçãa } \\ \text { LQ } & \text { Limite de Quantificação } \\ \text { NIST } & \text { National Institute of Standards and Technology } \\ \text { NWRI } & \text { National Water Research Institute } \\ \text { pH } & \text { Potencial Hidrogeniônico } \\ \text { SANEAGO } & \text { Saneamento de Goiás } \\ \text { SIEG } & \text { Sistema de Informação Geográfica do Estado de Goiás } \\ \text { TDS } & \text { Total de Sólidos Dissolvidos }\end{array}$




\section{CAPÍTULO 1}

INTRODUÇÃO

\subsection{Apresentação}

A água é um componente natural indispensável à vida e ao desempenho de diversas atividades econômicas e industriais. Embora seja um recurso renovável, é finito e sua qualidade vem sendo danificada. O planeta Terra possui quase dois terços de sua superfície coberta por água, dos quais menos de $1 \%$ representa água doce contida em lagos, rios, no solo e subterrâneo (ESTEVES, 1998). Os rios são recursos de água doce essencial ao homem, sendo que no passado, o desenvolvimento social, econômico e político foram fortemente influenciados pela disponibilidade e distribuição da água contida nos sistemas fluviais (MEYBECK et al., 1992).

Nos moldes do desenvolvimento econômico atual, grande parte da água ainda é utilizada de forma irracional e não sustentável. Este fato agrava-se ao passo que ocorre a distribuição heterogênea dos recursos hídricos. Consequentemente, constata-se que a água não se encontra a disposição e com qualidade para atender a todas as necessidades humanas (BERNARDI et al., 2013). O uso de pesquisas, planejamento e políticas, envolvendo o uso e a disponibilidade de recursos hídricos, é uma forma de promover a gestão das águas de rios e lagos (BRAGA et al., 2005). Esse procedimento pode ser realizado tendo como base o gerenciamento de bacias hidrográficas. Isso porque, esta é uma área onde se pode observar com facilidade a variação do volume hídrico e a intensidade das precipitações pluviais. Com isso, a hidrodinâmica pode ser então melhor administrada, dependendo apenas da escala de análise da bacia hidrográfica em questão (LIMA, 2010).

A bacia hidrográfica é uma área da superfície terrestre que drena água, sedimentos e materiais dissolvidos para uma saída comum, num determinado ponto de um canal fluvial. $\mathrm{O}$ limite de uma bacia de drenagem ou divisor de águas (COELHO NETO, 2003). Essa interação é denominada rede de drenagem, a qual é composta de, no mínimo, um rio principal e seus afluentes, que distribuem a água por toda a bacia (TUCCI, 1993).

Nesse sentido, a bacia hidrográfica é um dos meios mais eficazes de gestão dos recursos hídricos, foco de pesquisa por tratar de uma estreita inter-relação entre a ação das águas e o ambiente com os vários elementos da paisagem: material parental, geomorfologia, topografia, vegetação e tipologia climática. Nesse sentido, de acordo com Botelho (1999) acredita-se que, 
o estudo das inter-relações existentes nos processos que atuam na sua formação e dos elementos de paisagem, esteja conectado à possibilidade de alagamento e assoreamento da área da bacia, mediante processos erosivos e carregamento de material particulado por drenagens. Bacia é uma unidade de planejamento física bem caracterizada, especialmente pela composição química e funcionalidade dos elementos que dela participam, como os rios, a vegetação e o solo. A água apresenta algumas características peculiares dadas pela geologia e influenciadas pelo tipo de solo, as condições climáticas, a formação e o tamanho das bacias de drenagem (DONNADIO et al., 2005).

Diante da importância das bacias hidrográficas, torna-se necessário abordar a complexidade de suas características. Uma vez que, por menores que sejam, sofrem interferências de diversos fatores, sejam naturais, antrópicos ou de processos que determinam, ou alteram suas características e interferem na disponibilidade dos elementos químicos no ambiente (ARVOCA et al., 1998; STRANDBERG, 1971). Entre as atividades que afetam a qualidade das bacias hidrográficas, destaca-se a presença de compostos orgânicos, a industrialização, a urbanização, e o uso de agrotóxicos e os fertilizantes na agricultura. Essas atividades poluidoras podem ser pontuais quando se referem aos poluentes disseminados em pontos específicos dos corpos d'água como, por exemplo, no tratamento de esgotos e indústrias. E também podem ser classificadas como difusa quando os poluentes atingem o corpo hídrico de modo aleatório, exemplificado pelo escoamento de água da chuva (PENIDO, 2010).

As análises da água e sedimento são de grande relevância na avaliação dos impactos ambientais, pois fornecem a assinatura geoquímica da área em que será estudada, caracterizando a evolução do impacto sofrido pelo ecossistema, permitindo com isso aferir a degradação ambiental e buscar informações consistentes para gestão de áreas impactadas (LIMA, 2008). Para isso, torna-se necessário o delineamento de indicadores capazes de indicar desequilíbrios causados por fatores como intemperismo, erosão e sedimentação em diversos ambientes aquáticos, caracterizar suas fontes contaminantes e suporte de ecossistemas naturais, capazes de fornecer confiáveis implantações de atividades antrópicas (LACERDA, 2006).

Dentro desse contexto, o Estado de Goiás vivencia uma intensa ocupação territorial e excessiva utilização dos recursos ambientais, reduzindo na década de 1960 suas formações florestais nativas a 34\%, concentrados principalmente no nordeste goiano (SEPLAN, 2011). 
Uma das principais causas foi à intensa expansão de suas fronteiras agropecuárias, que refletiu nos recursos hídricos, devido à cobertura vegetal exercer uma íntima ligação com a qualidade de água, por desempenhar um papel de proteção e retenção de impurezas e esse uso excessivo agrícola e urbano acarretou diminuição de sua qualidade (BONNET et al.,2008). Estudos realizados por Oliveira et al.,(2001), relatam problemas associados à contaminação em bacias hidrográficas no Estado de Goiás em decorrência da forte atividade agropecuária. Como exemplo, ele cita as cidades de Anápolis, Cristalina, Crixás, Cidade de Goiás, Mairipotaba, Porangatú, Piracanjuba, Catalão, Bela Vista, Caldazinha, entre outros, que sofrem com as condições agravantes como desmatamentos indiscriminados, compactação e erosão dos solos, utilização de produtos químicos como agrotóxicos e fertilizantes e a retirada das Áreas de Preservação Permanentes (APP) que traz danos na qualidade e quantidade de água que chegam aos mananciais utilizados no abastecimento público. Assim, é necessário um planejamento adequado, correlacionado a medidas mitigadoras, de modo a alcançar-se um desenvolvimento sustentável sob a ótica tanto econômica, quanto ambiental.

Desta forma, fica demonstrada a necessidade de uma avaliação das condições ambientais observadas na coluna dos corpos hídricos, a fim de conhecer suas distribuições no ecossistema, e seu perfil em função do tempo (TERNUS, 2007). Assim, o estudo geoquímico da água e sedimento fornecerá uma compreensão da dinâmica e avaliação do grau de impactos das atividades antrópicas.

O Estado de Goiás representa no cenário nacional, uma área de 340.086,698 km², Goiás é o sétimo estado do país em extensão territorial, sendo contemplado com três regiões hisrográficas: Região Hidrográfica São Francisco, Região Hidrográfica Tocantins e Região Hidrográfica Paranaíba (MACHADO, 2006). A localização e a quantidade de bacias hidrográficas proporcionam ao Estado de Goiás uma vazão total média de, aproximadamente, $4.762 \mathrm{~m}^{3} \mathrm{~s}^{-1}$ e uma vazão média específica de $14 \mathrm{~m}^{3} \mathrm{~s}^{-1}$ com uma disponibilidade hídrica per capita de $28 \mathrm{~m}^{3} /$ hab./ano (SEMARH, 1999). O córrego Campo Alegre, na cidade de Campo Alegre/GO, pertence à bacia do rio Veríssimo, sub-bacia do Rio Paranaíba que possivelmente sofre ao longo dos anos diversos impactos decorrentes da ação antrópica.

De acordo com Matos et al., (2012) o município de Campo Alegre de Goiás é formado por áreas de chapada, que são propícias à agricultura, o que levou a um crescimento econômico na região ocasionando um adensamento populacional devido principalmente ao aumento de mão de obra, havendo com isso uma expansão gradativa da zona urbana, 
acarretada pela busca da melhoria da qualidade de vida da população como educação, moradias, saúde, entre outros.

Todos esses fatores favorecem o comprometimento dos recursos hídricos, sendo o principal impacto identificado associado ao uso inadequado de agrotóxicos nas atividades agrícolas que podem comprometer a qualidade de águas superficiais e desta forma gerar problemas à população local, bem como à fauna e flora existentes. Outros fatores não menos importantes que interferem na qualidade dos recursos hídricos são as atividades domésticas e comerciais como descargas de domicílios, lava-jatos, postos de gasolina, fossas sépticas, chorume de antigos lixões e cemitérios, áreas de garimpos ilegais e extração de areia.

\subsection{Objetivos}

O objetivo geral dessa pesquisa é avaliar a qualidade da água na bacia do Córrego Campo Alegre, determinando as possíveis fontes de alteração e diferenciando os impactos relacionados à interferência humana dos processos naturais controlados pela geologia regional e pedologia local.

Como metas propõem-se:

- Analisar a qualidade da água superficial do Córrego Campo Alegre utilizada para abastecimento público a partir de parâmetros químicos $(\mathrm{pH}$, condutividade, total de sólidos dissolvidos, metais e elementos traços);

-Identificar possíveis fontes dos compostos de contaminação, determinando como os diferentes controles - geogênico, pedogênico e antropogênico;

-Determinar os valores de referência local (background) e as intervenções antrópicas na nascente e no trecho urbano do córrego Campo Alegre com base nas concentrações de elementos maiores e de elementos-traços;

-Analisar a concentração de metais nos sedimentos para identificação de possíveis fontes de contribuição naturais e antrópicas.

\subsection{Justificativa}

Apesar da pesquisa proposta ser baseada na aplicação de técnicas tradicionais e difundidas na literatura, o trabalho é de extrema importância, uma vez que trata de uma iniciativa inédita e pioneira, visto que este tipo de avaliação da qualidade ambiental nunca foi realizada no alto curso da bacia do córrego Campo Alegre. 
Apenas Oliveira (2001) realizou uma análise química da qualidade da água na área de estudo, no entanto, nenhum trabalho determinou a composição da água e do sedimento com as possíveis fontes de alteração e diferenciação de interferência humana dos processos naturais influenciados pela geologia local que será tratado na pesquisa em questão. A partir do exposto é que se justificam os estudos dos constituintes maiores e traços na água e no sedimento do referido córrego a fim de determinar valores de referência geoquímica regional, por meio da determinação de áreas de background e comparação com áreas providas de possíveis interferências antrópicas, para assim criar um referencial para identificar as fontes dos elementos no ambiente. Essas análises proporcionarão o melhor entendimento dos processos e influência dos fatores naturais e antrópicos, reconhecendo, assim, seus mecanismos e consequências com base em uma avaliação geoquímica. 


\section{CAPÍTULO 2}

\section{ASPECTOS FISIOGRÁFICOS E GEOLÓGICOS DA ÁREA}

\subsection{Localização e Acesso da área de estudo}

A área de estudo situa-se no município de Campo Alegre de Goiás no planalto Brasil Central, Sudeste do Estado de Goiás, com a latitude 17³8'20' Sul e uma longitude 47²6'55', Oeste em UTM (UTM N: 804.759 e UTM E: 204.807), a 760m acima do nível do mar (OLIVEIRA, 2001).

O município de Campo Alegre de Goiás possui uma área total de 2.463,014 km² (IBGE, 2013), com uma população de 6.060 habitantes. O acesso ao município a partir de Brasília se faz pela BR -050 direção Catalão/São Paulo.

A área em estudo está localizada no Córrego Campo Alegre na bacia hidrográfica do Rio Veríssimo, na sub-bacia do sul do Rio Paranaíba e abarca os municípios Campo Alegre de Goiás, Corumbaíba, Anhanguera, Cumari, Catalão, Ipameri, entre outras (Figura 2.1).

\subsection{Geomorfologia}

A área apresenta um relevo plano, constituída por superfícies tabulares e aplainada referente ao embasamento cristalino, além de superfícies planálticas e serras com níveis altimétricos variando entre 700 a 1000 metros. O relevo é dissecado com declividade inferior a 3\%, com rampa bem ampla e sem erosão aparente sendo classificado como dissecação homogênea tabular. A sua topografia é classificada como $60 \%$ ondulada, $30 \%$ plana e $10 \%$ montanhosa, além das regiões várzeas (AGET, 2004).

A região é recoberta por um solo detrítico laterítico de idade Cenozóica, com características de latossolo vermelho-amarronzado, constituindo perfis maturos e imaturos, além de níveis de cascalhos. Encontra-se também na área sedimento aluvial ou coluvial representado por conglomerado oligomítico com clastos de quartzito e laterito autóctone com carapaças ferruginosas (AGET, 2004, Figura 2.2). 


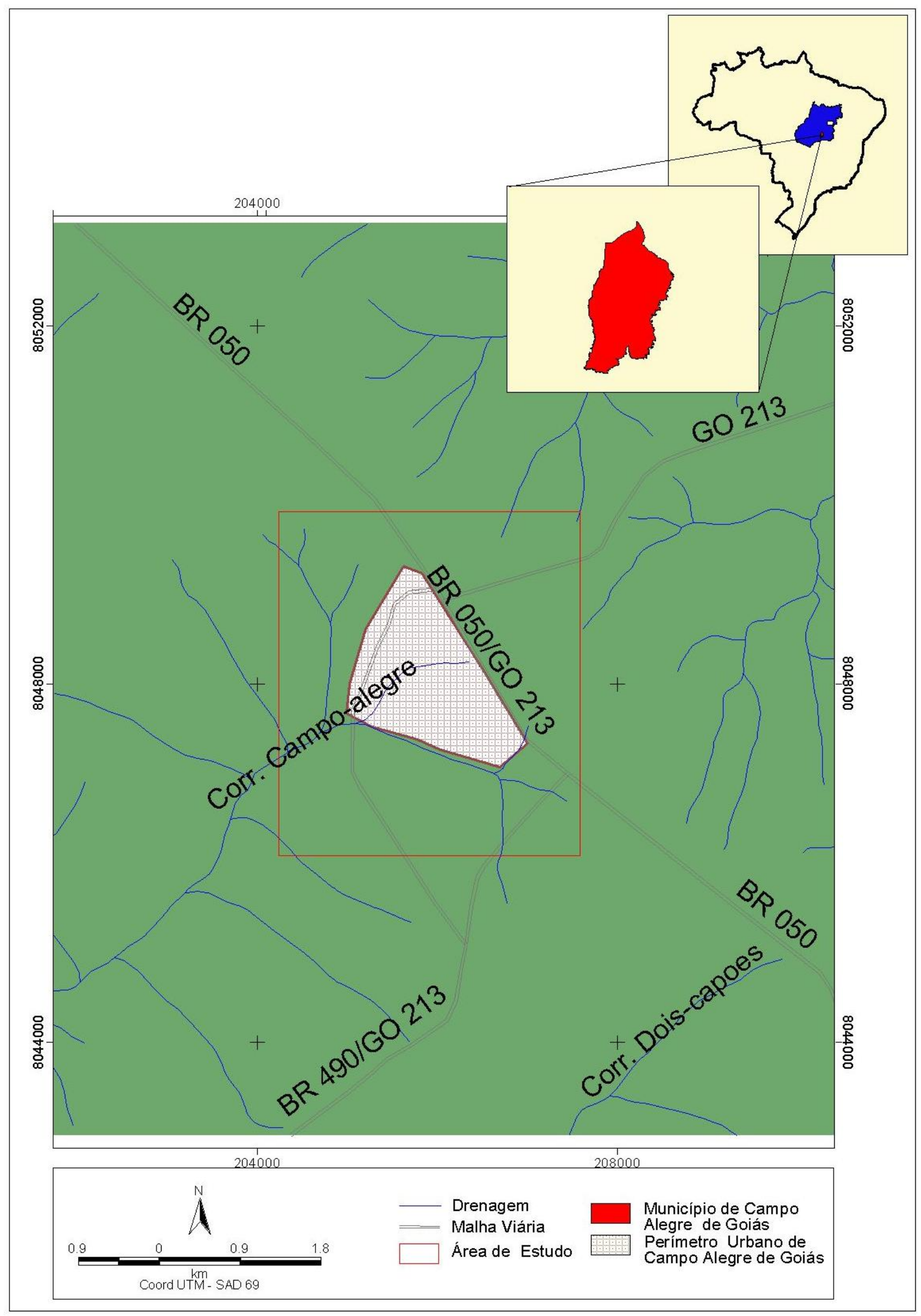

Figura 2.1 - Mapa de localização e acesso da área em estudo (SIEG, 2013). 


\subsection{Hidrografia}

O sistema de drenagem compreende o conjunto hidrográfico das bacias do Rio Veríssimo, São Marcos e Rio Corumbá que são afluentes do Rio Paranaíba, com padrão de drenagem misto dentrítico-paralelo, sendo assim essas características são atribuídas ao córrego Campo Alegre que se encontra na bacia do Rio Veríssimo (Figura 2.2).

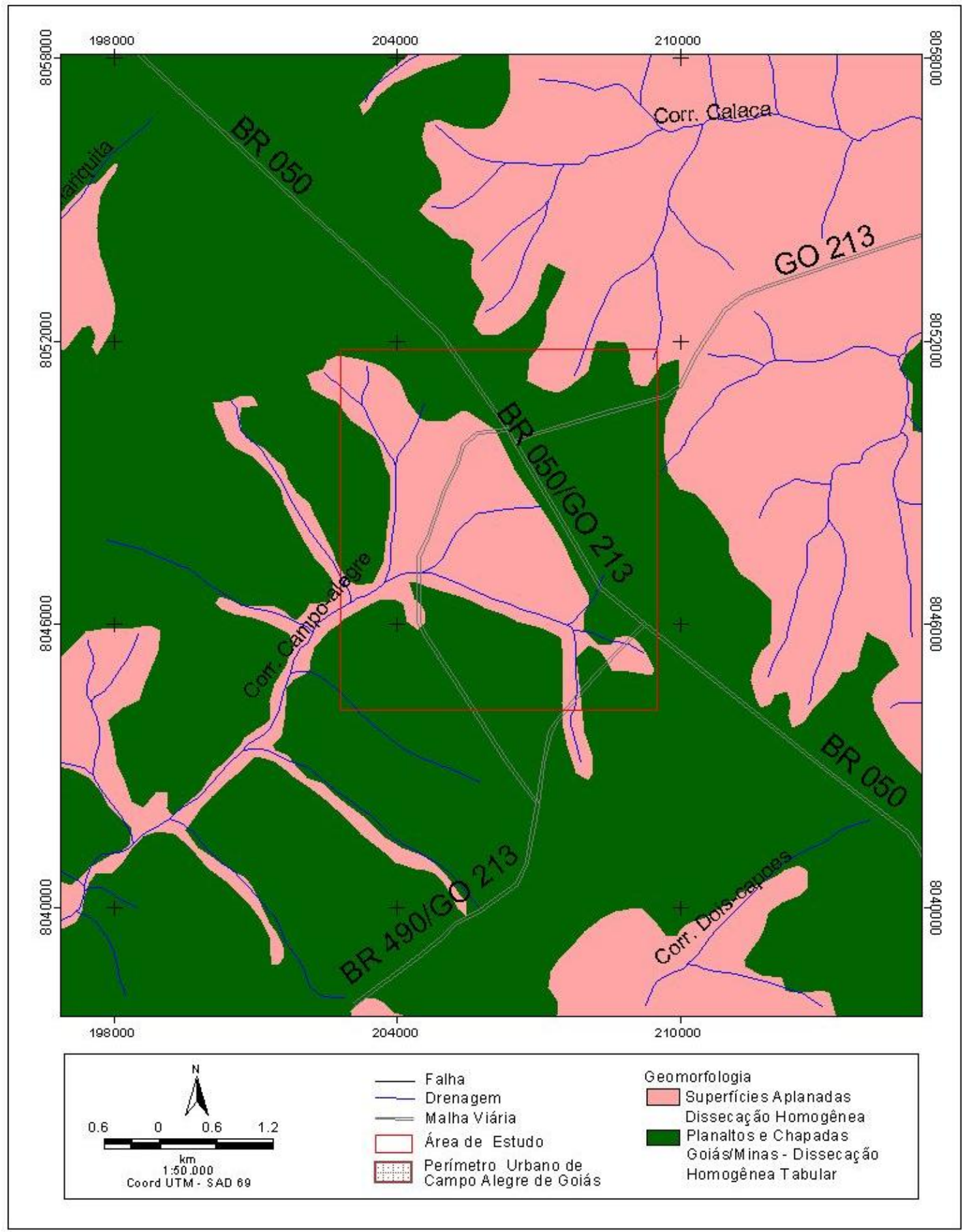

Figura 2.2 - Mapa Geomorfológico e Hidrográfico da área de estudo (SIEG, 2013). 
Os tributários apresentam seus cursos escoando praticamente paralelos entre si, sendo que os mais significativos são o córrego Campo Alegre e Córrego Mariquita (OLIVEIRA, 2001).

O município se encontra no alto da chapada, na cabeceira de drenagem do córrego Campo Alegre, ou seja, toda possível poluição atingirá a bacia. Portanto, é relevante saber qual proporção de contaminação advinda da cidade e do uso do solo pela agricultura.

A Bacia do córrego Campo Alegre, possui a cota mais alta entre $980 \mathrm{~m}$ em seu divisor e cota mais baixa na foz da bacia do Rio Veríssimo com $715 \mathrm{~m}$. A cidade se encontra entre 950 e $880 \mathrm{~m}$ em seu divisor Nordeste. A área da bacia corresponde a 145, $3 \mathrm{~km}^{2}$ e a área da cidade 2, $42 \mathrm{~km}^{2}$. Existe amplitude (diferença de nível entre mais alto e mais baixo) 2,65 km e o gradiente (inclinação) corresponde a 14\%, com a linha da foz até o divisor mais alto de 18,6 km (SIEG, 2013).

A vazão do Córrego Campo Alegre possui as seguintes série mensais, em período de 1971 a 2004, q média: 15, $81 \mathrm{~L} / \mathrm{s}$. $\mathrm{Km}^{2}$, q mínimo: 1, $67 \mathrm{~L} / \mathrm{s} . \mathrm{Km}^{2}$ As precipitações anuais médias são de $1500 \mathrm{~mm}$, com as ocorrências representativas de maio a setembro, e as precipitações médias não ultrapassam $100 \mathrm{~mm}$ no período de maio e agosto. Os meses de julho a setembro identificam-se por um período intenso de estiagem, acompanhada dos maiores índices de insolação, marcado por grande índice de evapotranspiração das plantas e aumento de irrigação (FLORÊNCIO et al., 2002).

As condições climáticas da bacia são marcadas por características do relevo com chapada e chapadões, clima quente e úmido, chuvas de verão, com médias térmicas variando de $19^{\circ} \mathrm{C}$ a $28^{\circ} \mathrm{C}$. O clima da área obedece à dinâmica da savana Cerrada, com duas estações bem definidas uma seca, que inicia no mês de maio ao fim de setembro e outra chuvosa, que vai de outubro a abril, com temperaturas médias anuais entre $22^{\circ} \mathrm{C}$ e $27^{\circ} \mathrm{C}$ com precipitação média anual de $600 \mathrm{~mm}$ a $2000 \mathrm{~mm}$ (MACHADO, 2009).

\subsection{Vegetação}

De acordo com Oliveira et al., (2001), a vegetação apresenta diferenciadas denominações florestais formada por Cerradão (Savana Arbórea Densa), Cerrado (Savana Densa), o Campo Cerrado (Savana Arbórea Aberta), Campo Limpo de Cerrado (Savana Arbórea Aberta), Campo Sujo de Cerrado (Savana Parque) e Formação Campestre (Savana Parque). As formações florestais do Cerrado são constituídas por Mata de Galeria, Mata 
Ciliar, Mata Seca e Cerradão. A Mata Ciliar e Mata de Galeria são formações ribeirinhas. A vegetação mais representativa é o Campo Cerrado, porém sua maior parte é substituída pela agricultura como pode ser observada na Figura 2.3. Normalmente ocupa superfícies altas e planas, com aspectos diversos representando os denominados campos sujos e limpos. Os Campos sujos são predominantes, com árvores mais baixas e afastadas entre si. Estão relacionados a solos rasos e pedregosos, pouco permeáveis, enquanto que as gramíneas são mais baixas do que no estrato rasteiro dos cerrados. A formação florestal é esparsa e com fortes intervenções antrópicas, atingindo também as matas ciliares, que na maior parte das vezes ocorre devido à substituição de parte da floresta por pastagens e atividades agrícolas (Figura 2.3, MACHADO et al., 2009).

Nesta região, também apresenta grandes extensões de áreas desmatadas. Ao longo da microbacia em estudo, tem-se ainda a presença de matas ciliares que em sua maior parte encontra-se modificado pela ação antrópica (OLIVEIRA, 2001).

O solo, o clima e a intensidade das chuvas contribuem para a variedade da vegetação do município de Campo Alegre, que é constituído principalmente por pequizeiros, lobeiras, mangabeiras, pau-de-óleo, barbatimão, entre outros, que tem sido substituído por pastagens e plantações de soja, milho, algodão, entre outros. O município possui pequenas matas denominadas Capões onde se encontram madeiras de grande valor comercial, além de florestas de eucalipto.

Dados obtidos por Matos et al., (2012), evidenciam que parte do uso de terra de Campo Alegre de Goiás é a agricultura, principalmente nas áreas de chapada, com número considerado de pivôs, ou seja, agricultura irrigada (Figura 2.3). Essas áreas se configuram em "ilhas de modernidade" em decorrência às densidades técnicas no processo produtivo, tornando-se assim território de reprodução do capital devido a economia agrícola tomar dimensões mundiais na região consequência disso crescendo gradativamente trazendo modificações no uso do solo com o tempo, onde a área que anteriormente era usada também para pecuária, atualmente se restringe a basicamente agricultura causando com isso a destruição do Cerrado em relação às outras áreas do município (OLIVEIRA, 2001). 


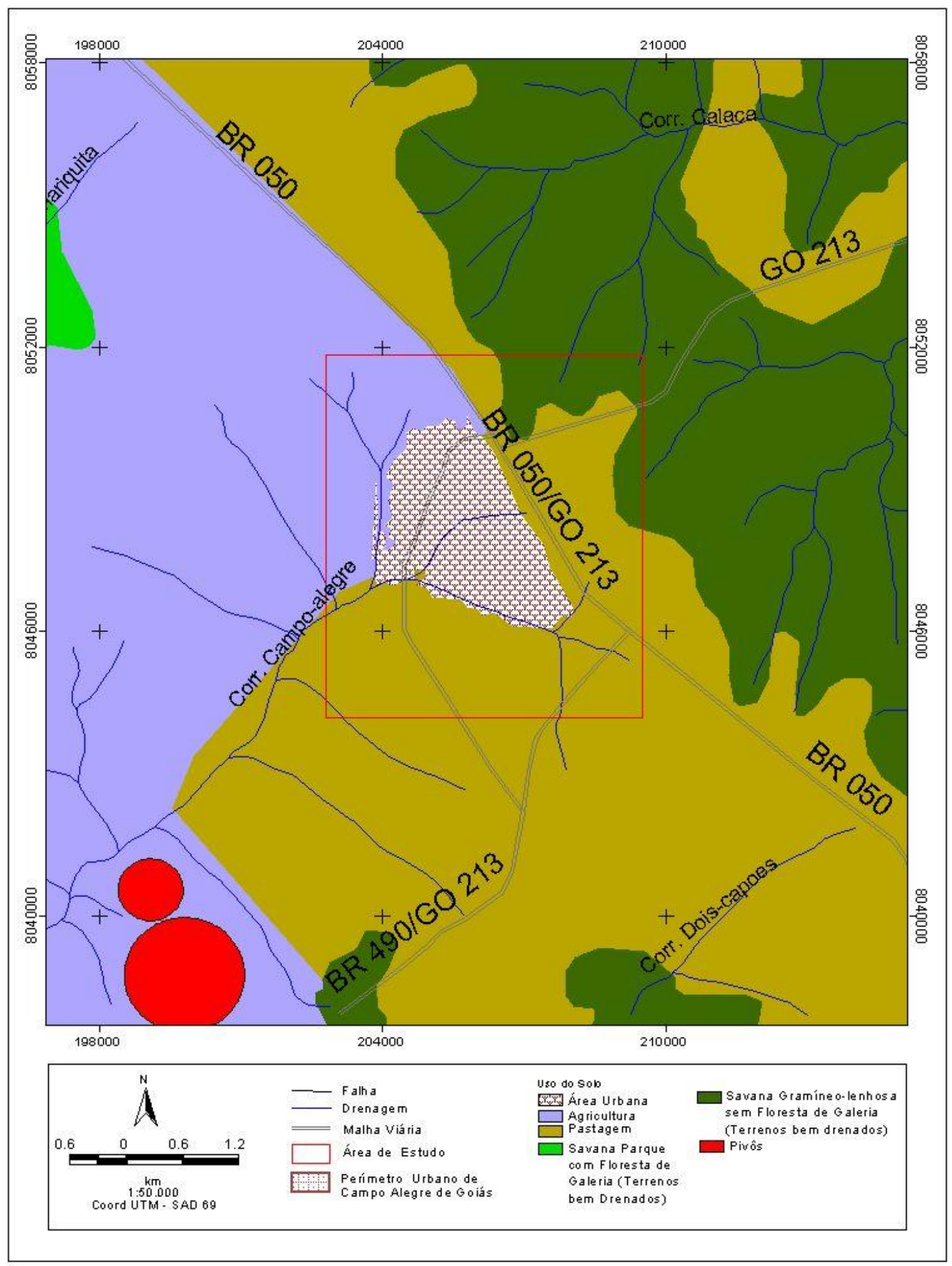

Figura 2.3 Mapa de uso do solo e coberta vegetal da área de estudo (SIEG, 2013). 


\subsection{Solo}

O latossolo no Cerrado corresponde a $43 \%$ da área da bacia do córrego Campo Alegre total com baixo teor de nutrientes químicos, porém com alto grau de acidez. São considerados solos minerais, acentualmente drenados, muito porosos, com horizontes espessos e de pouca diferenciação entre si (CARNEIRO et al., 2009; Figura 2.4).

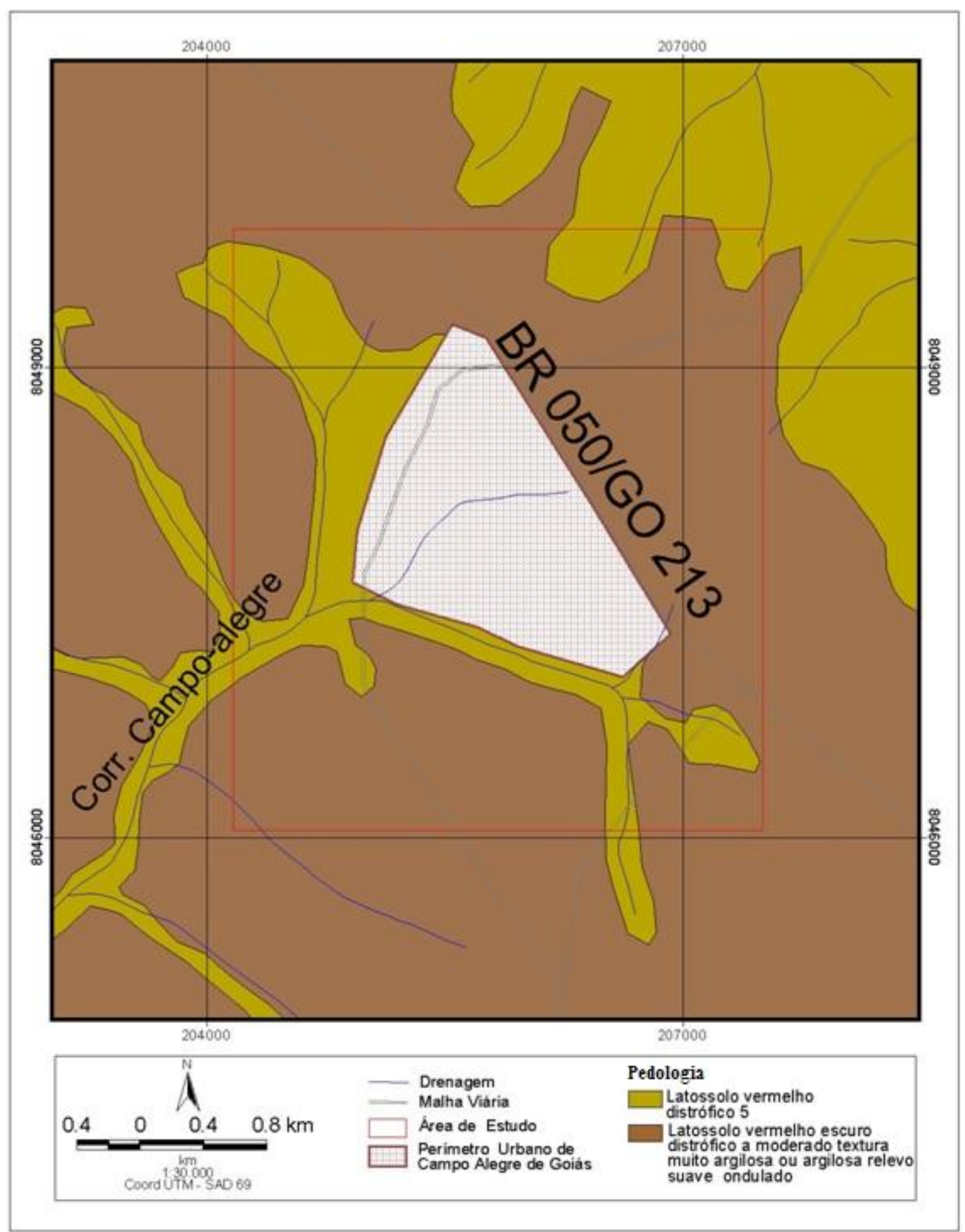

Figura 2.4 Mapa de solos (SIEG, 2013). 
O solo do Cerrado origina-se de rochas antigas, com idades que variam de 570MA a 4,7GA. A formação do tipo de solo latossolo é devido à laterização de rochas Pré-Cambrianas durante o período Terciário, ajustando-o ao tipo de clima da região. Os latossolos são ricos em argila e óxido de ferro que dão as características avermelhadas, textura argilosa e profunda, porosa e permeável. Caracterizam-se também pela boa drenagem, são friáveis, com baixa fertilidade natural, sendo aproximadamente $90 \%$ ácidos devido a alta concentração de ferro e alumínio (RODRIGUES, 1996).

A baixa fertilidade deste solo é agravada pelas chuvas fortes e concentradas, que carreiam nutrientes como ferro e alumínio para as profundidades do solo provocado pelo escoamento superficial, aumentando sua deficiência. Tal deficiência em solos ácidos pode limitar o crescimento de plantas, devido à alta concentração de alumínio, inibindo a absorção de nutrientes pelas raízes, ou mesmo causando toxidez às plantas. No cerrado o alumínio combina com o fósforo formando uma substância chamada fosfato de alumínio. Este se precipita no solo e não pode ser absorvido pelas raízes, fazendo com que a concentração de fósforo seja diminuída, exigindo a correção da acidez, o que geralmente é feito com calcário (RODRIGUES, 1996).

\subsection{Geologia}

O município de Campo Alegre de Goiás se encontra localizado na parte sudeste do Estado de Goiás, inserido na folha SE. 23-V-C-IV (1: 50.000), constituída pelos grupos Ibiá, Araxá, Canastra e a Sequência vulcano-sedimentar do Rio Veríssimo, recoberto por solos vermelhos ricos em laterita (CPRM, 2013, Figura 2.5).

As unidades aqui apresentadas são referidas na literatura geológica em diferentes níveis de hierarquia e posicionamento lito-estratigráficos. De acordo com dados apresentados em normatização dada pelo Código Brasileiro de Nomenclatura Estratigráfica.

O Grupo Araxá fica posicionado sobre a Formação Canastra, em decorrência de uma discordância do tipo "não conformidade"materializada, sobretudo por uma diferença de grau metamórfico".

As rochas que constituem a "Formação Ibiá", foram descritas pela primeira vez tendo como seção-tipo a pedreira da cidade de Ibiá, no alto Rio Quebra Anzol, MG. A princípio, posicionaram a unidade constituída por calcixistos na base do Grupo Canastra, considerando os xistos do Grupo Araxá sempre cavalgantes sobre ela. Os dois litotipos Ibiá apresentam 
características petrográficas e sedimentológicas distintas, espessuras de centenas de metros e continuidade lateral de quase uma centena de quilômetros, podendo ser definidos como formações. Dessa forma, a unidade Ibiá alcança a categoria hierárquica de Grupo Ibiá, tendo duas formações: Formação Cubatão e Formação Rio Verde.

\subsubsection{Grupo Ibiá}

O Grupo Ibiá está posicionado acima do Grupo Canastra e representa um conjunto de metamorfitos originalmente descritos próximo à cidade de Ibiá, Minas Gerais. Compreende um conjunto de metassedimentos detríticos metamorfisados por xisto verde, constituído por filitos, calcixistos, calcifilitos verdes ricos em biotita, clorita xistos, sericita xistos, metadiamictitos e quartzitos subordinados. É uma unidade geológica de mais baixo metamorfismo na sinforma de Araxá, alcançando no máximo, a zona da clorita da fácies xisto verde (PEREIRA, 1992; Figura 2.5).

Desse modo, a unidade Ibiá, é dividida em duas formações por Pereira (1992): Formação Cubatão, conglomerática, na base e Formação Rio Verde, filítica, no topo. As melhores exposições do Grupo Ibiá, localizam-se nos vales do Rio Verde e dos seus afluentes.

A Formação Cubatão localiza-se diretamente sobreposto aos ritmitos de filitos e quartizitos do grupo Canastra, com marcada discordância erosiva, repousam os paraconglomerados da base do Grupo Ibiá, englobados na Formação Cubatão.

As melhores exposições estão na parte norte, enquanto a sul estas se apresentam bastante intemperizadas e com espessura reduzida. Trata-se de uma rocha com abundante matriz de composição metapelito-carbonata, na qual flutuam fragmentos de diferentes tamanhos, formas e litologias. Não se observa estratificação bem definida, no entanto, pode-se definir bandas métricas com maior ou menor concentração de seixos e uma redução no tamanho destes, contato entre bandas. A matriz da rocha é constituída por clorita, sericita, muscovita, carbonato e quartzo de granulometria fina (PEREIRA, 1992).

A Formação Rio Verde localiza-se sobre o meta-paraconglomerado repousa extenso e monótono pacote de calcifilitos, formado por bandas centtimétricas e rítmicas, quartzosas e micáceas, que constituem a Formação Rio Verde. O contato basal do calcifilito com o metaparaconglomerado da Formação Cubatão é gradacional. Em lâmina delgada é nítida esta gradação, pois os filitos, na zona de contato, exibem fenoclastos que se tornam mais raros ao se afastar dela,passando ao calcifilito típico, finamente bandado (KLEIN,2008). 
Mineralogicamente, o calcifilito mostra-se semelhante à matriz do metaparaconglomerado, sendo constituído, nas bandas micáceas, por clorita e sericita/ muscovita e nas bandas quartzosas, por quartzo fino e fenoclastos de quartzo, feldspato potássico, plagioclásio e calcita (PEREIRA, 1992).

Grande porção na área de estudo é formada sobre o conglomerado matriz-suportado basal repousa extenso e monótono pacote de calcifilitos verdes ricos em biotita, formado por clorita, muscovita, quartzo, com lentes de quartzitos brancos, veios de quartzo recristalizados e intercalações de mármores resultantes de metamorfismo na fácies xisto verde baixo, zona da clorita (KLEIN, 2008).

\subsubsection{Grupo Araxá}

O Grupo caracteriza-se como um complexo metamórfico pré-cambriano, constituído por xistos verdes, micaxistos e migmatitos e é subdividido em duas unidades A e B: a primeira é representada por quartzitos, micaxistos e rochas feldspáticas, e a segunda por lentes de calcários micáceos marmorizados com intercalações de quartzitos, considerados uma das sequencias mais antigas (KLEIN, 2008).

A Sequência vulcano-sedimentar do Rio Veríssimo foi definida por Dardenne et al. (1994). Ela se encontra entre as cidades de Campo Alegre e Ipameri, nas mediações do povoado de Sesmaria. É composta por um conjunto de rochas vulcano-sedimentares, disposta em faixas alongadas e estreitas, de direção N-S, individualizadas com pertencentes à base do Grupo Araxá, em contato tectônico com o Grupo Ibiá e cortadas pelos granitos Sesmaria, Embu e Encruzilhada. Essa sequência é formada por clorita xistos, alguns porfiroblastos sub centimétricos de granada, sobrepostos por sericita filitos com lentes de quartzito e filito carbonoso (Figura 2.5). 


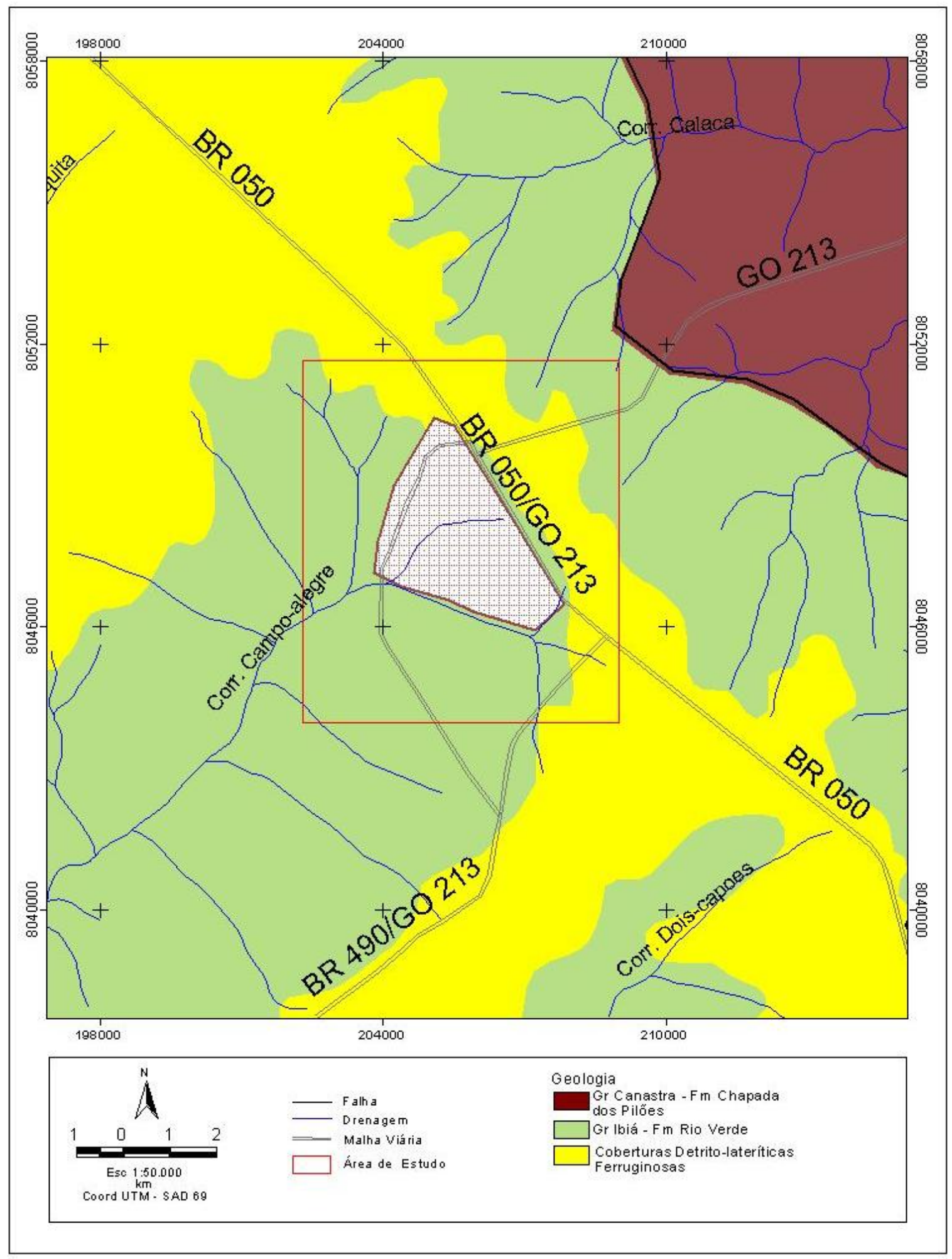

Figura 2.5 - Mapa Geológico da área de estudo (SIEG, 2013). 


\section{CAPÍTULO 3}

BASES CONCEITUAIS

\section{1 Água}

A água é constituída por dois átomos de hidrogênio e um de oxigênio. No estado líquido, suas moléculas se encontram unidas por ligações de hidrogênio-denominadas pontes de hidrogênio. Podem conter também sais, como nitratos, cloretos e carbonatos; além de elementos sólidos, poeira e areia que podem ser carreados em suspensão. Outras substâncias químicas podem dar cor e gosto à água, além de alguns íons causarem reações químicas alcalinas ou ácidas. As temperaturas também podem apresentar variações de acordo com a profundidade e o local onde a água é encontrada, constituindo-se assim, em fatores que influenciam em seu comportamento químico (ANA, 2013). Ela também é caracterizada como um solvente quimicamente ativo capaz de reagir com o meio percolado, incorporando substâncias orgânicas e inorgânicas (FAUST, 1981), onde quase todas as substâncias podem ser dissolvidas pela água devido as suas características físico-químicas que lhe conferem alta solubilidade, assumindo um papel relevante no ecossistema (ECHEVERRIA, 2006). Segundo esse autor, a água é um recurso natural renovável de origem mineral importante para a vida no planeta, por ser um dos componentes fundamentais para a existência do ser humano e desenvolvimento econômico.

Os principais constituintes presentes na água originam-se de processos físicos e químicos de intemperismo de rochas. O intemperismo físico associa-se com a fragmentação de rochas e o químico a processos que modificam o mineral por reação de hidratação/hidrólise, dissolução e precipitação, desse modo, forma os minerais secundários que são liberados e incorporados ao meio aquático. Além do intemperismo, a composição da água depende do tipo de solo, das variações de relevo, da temperatura, da precipitação, da cobertura de vegetação e da presença de organismos. Porém essa composição natural pode ser alterada por interferências antrópicas em função do uso e ocupação do meio. As principais fontes de poluição dos recursos hídricos se dão pela disposição inadequada de resíduos domésticos, industriais, de mineração e fertilizantes agrícolas, podendo interferir na adequabilidade das águas (FAUST, 1981).

Os ecossistemas são moldados de acordo a sua disponibilidade de água, onde essa disponibilidade de água não se relaciona somente na quantidade, mas também na qualidade adequada para suprir as necessidades vitais. Durante muitos anos esse recurso natural foi 
considerado um bem infinito, capaz de se autodepurar, mas sua veloz degradação propiciou uma preocupação quanto à qualidade de água para consumo humano (SILVEIRA, 2007). De acordo com alguns especialistas $95,5 \%$ da água do planeta é salgada e imprópria para o consumo humano, 4,7\% estão em geleiras ou regiões com acesso restrito e apenas $0,147 \%$ aptos para o consumo e encontra-se em lagos, nascentes e lençóis freáticos (GIRARDI, 2012).

No âmbito mundial, há um acentuado desequilíbrio na disponibilidade e qualidade da água. As principais causas são o aumento da população e sua concentração em núcleos urbanos, elevado grau de desmatamento, deterioração de bosques resultando em um menor aproveitamento das precipitações, exploração excessiva de aquíferos, o crescente dano por contaminação da qualidade das águas superficiais, entre outros. Essas causas consideradas agravantes não devem ser tratadas de modo isolado e dissociado das questões globais do meio ambiente. São necessárias integrá-las com as políticas ambientais que tratam dos demais recursos ambientais (ALMEIDA, 2010).

O Brasil possui um potencial hídrico de aproximadamente $36.000 \mathrm{~m}^{3}$ de água por habitante. Entretanto, $80 \%$ se localizam na região amazônica onde residem $5 \%$ da população brasileira. Por outro lado, a região nordeste que responde por $13 \%$ da população brasileira possui apenas 3,3\% da disponibilidade hídrica (TUCCI et al., 2002).

As principais atenções referentes aos recursos hídricos no país, diz respeito à demanda demográfica e à consequente poluição dos corpos d'água, afirmando que a água vem se tornando um bem escasso. Como modo de solucionar, é necessário que a gestão dos recursos hídricos proporcione o uso múltiplo das águas (CONAMA, 2005).

O gerenciamento dos sistemas aquáticos é considerado o instrumento que monitora os recursos naturais, econômicos e sociais, instruindo o poder público e a sociedade da situação ambiental de modo a promover o desenvolvimento sustentável. Para isso, é essencial determinar o estado atual do ambiente, identificar as fontes poluidoras, estabelecer limites mínimos de aceitação para que possam ser detectados e prognosticados os danos prováveis (FERRIER et al., 2001).

Diversos pesquisadores como Carvalho (2009), Toledo (2002) e Freitas (2001) direcionam cada vez mais a atenção à disponibilidade natural de água, devido a recorrentes problemas de escassez, poluição, distribuição e transformação antrópica da paisagem, onde o principal desencadeador dessas transformações é a elevação do índice de consumo de água no Brasil, principalmente em áreas de grande densidade demográfica, uma vez que o crescimento 
populacional eleva o consumo de água, principalmente pela demanda em maiores quantidades de alimentos e manufaturados, aumentando com isso a produções agrícola e industrial, maior geração de esgotos, ocasionando desfalque na distribuição de água (RANZINI et al., 2004).

Segundo Lima (2000), 91\% da população urbana e 9\% da rural no Brasil utilizam a água canalizada, e o restante precisam recorrer a métodos para a captação, como poços artesianos. A coleta de esgoto se resume a metade do que é gerado e apenas 1/3 do esgoto coletado é efetivamente tratado. A falta de saneamento básico é responsável por doenças como disenteria, diarreia, cólera e esquistossomose, além de grande parte de internações hospitalares e a mortalidade infantil.

A poluição causada aos corpos d'água conduz à necessidade de planos de prevenção e recuperação ambiental, a fim de garantir condições de usos atuais e futuros, para diversos fins. Esses planos, além de medidas de acompanhamento de suas metas através de fiscalização, requerem para a sua proposição e efetiva implementação, com dados que indiquem o estado do ambiente aquático. Para este fim são estabelecidos os programas de monitoramento da qualidade da água (SILVA, 2010).

\subsection{Bacia Hidrográfica e Microbacias}

Por elementos de uma bacia hidrográfica compreendem-se os componentes de toda a sua estrutura, o rio, o solo e a vegetação. A definição de bacia hidrográfica varia de autor para autor, a mais comum é a delimitação de um espaço topográfico da área de escoamento da chuva por um sistema interligado de corpos hídricos que convergem para uma única saída (CASSILHA; CASSILHA, 2009).

Schiavetti e Camargo (2002) definem bacia hidrográfica como um conjunto que envolve terras drenadas por um corpo d'água principal e seus afluentes representando a unidade mais apropriada para o estudo qualitativo e quantitativo do recurso água. Dill (2007) diz que ela é uma unidade física, caracterizada como uma área de terra drenada por um determinado curso d'água e limitada, perifericamente, pelo chamado divisor de águas. Independente de sua definição, o importante é que a maioria concorda que a bacia hidrográfica é um ambiente propício ao estudo das alterações ambientais.

Essa área é limitada por um divisor de águas que a separa das bacias adjacentes e que pode ser determinado nas cartas topográficas. As águas superficiais, originárias de qualquer 
ponto da área delimitada pelo divisor, saem da bacia passando pela seção definida e a água que precipita fora da área da bacia não contribui para o escoamento na seção considerada. Assim, "o conceito de bacia hidrográfica pode ser entendido através de dois aspectos: rede hidrográfica e relevo" (DILL, 2007).

As bacias também são classificadas em microbacias, sub-bacias ou pequenas bacias. As microbacias são definidas como aquelas áreas de drenagem tão pequenas que mesmo com a sensibilidade à chuva de alta intensidade e às diferenças de uso do solo podem ser determinadas as características da rede de drenagem (LIMA, 2000). São avaliadas por estudos sistemáticos que possibilitam conhecer somente as relações e funções internas dos ecossistemas e permitem o estabelecimento de um planejamento adequado de uso de terra (RANZINO, et al., 2004, CARNEIRO, 2002). Esses estudos afirmam que as principais produtoras de oxigênio das microbacias são a fotossíntese e a reaeração e os principais meios de consumo são oxidação e a nitrificação. Os efeitos maléficos da matéria orgânica em corpos hídricos e a redução dos níveis de oxigênio dissolvido se deram em decorrência ao consumo pelos decompositores.

Todos os componentes das bacias hidrográficas encontram-se interligados e os rios são veículos dessa integração. Devido à interligação natural, as bacias são excelentes unidades de planejamento e gerenciamento (SOUZA, 2005).

O processo de degradação das bacias hidrográficas, impactando os recursos hídricos, a biodiversidade (especialmente a ictiofauna), as populações residentes nessas bacias e, consequentemente, o próprio potencial de atratividade econômica, tem agravado a situação da escassez de água em todos os níveis: mundial, nacional e regional (BORGES, 2005). Para avaliar o possível efeito de qualquer perturbação numa bacia hidrográfica, é necessário conhecer as características e condições naturais de equilíbrio, e assim estabelecer comparações entre as condições hidrológicas e de qualidade da água no ecossistema natural e nos ecossistemas que ocorrem ações antrópicas (SANTOS et al., 2007). Estudos realizados por Moraes (2001), Toledo (2002) e Veiga (2006) mostraram que as implicações ambientais, como a ocorrência de toxidez e os efeitos adversos causados por produtos químicos nas bacias necessitam de um planejamento e monitoramento adequados para resguardar a qualidade ambiental dessas áreas. Souza (2005) acredita que qualquer ação sofrida em determinado ponto numa bacia hidrográfica, pode repercutir por longas distâncias, e enfatiza ainda que a qualidade final da 
água no rio ou córrego reflete necessariamente as atividades desenvolvidas em toda a bacia e que cada um de seus espaços físicos produzirão efeitos específicos e característicos.

Diversos pesquisadores têm realizado estudos em várias áreas nas bacias hidrográficas brasileiras, com o fim de conhecer suas características, desenvolvimento e meios para suas preservações.

Soares et al.,(2004), realizaram estudos geoquímicos de sedimentos de fundo na bacia do Arroio do Salso em Porto Alegre. Esses autores acreditam que para avaliar o grau de impacto antropogênico ou natural é necessário se obter o máximo de informações sobre a origem, características mineralógicas, físico-químicas e fatores naturais para obter resultados completos. Confirmaram ainda que a composição química do sedimento tem grande influência na mineralogia, e que os cálculos realizados apresentaram intensidade acentuada de contaminação e que os sedimentos foram classificados como pouco poluídos. Para esses autores, somente o $\mathrm{Cu}$, o Ni e o Zn indicaram alta contaminação, no curso médio do Arroio do Salso, principalmente em regiões de lançamento direto de efluentes domésticos.

Levantamentos realizados no ano de 2000 pelo Comitê de Bacias de Captação do Córrego Campo Alegre identificaram ocorrências de áreas impactadas, devido a desmatamentos nas cabeceiras das nascentes, topografia acentuada do terreno e o uso do solo pela agricultura com aplicação indiscriminada de agrotóxicos. As ações executadas a partir desses levantamentos visando à reversão ou minimização dessas constantes agressões foram programas integrados entre diversos órgãos para assegurarem a proteção e a preservação do recurso da água. Para isso, foram construídas Bacias de Captação de Murundus e recursos de reflorestamentos (SANEAGO, 2008).

Avaliações de impactos ambientais realizados através de estudos geoquímicos nos sedimentos do Ribeirão Piancó, em Anápolis, quantificando os elementos $\mathrm{Cu}, \mathrm{Cr}, \mathrm{Ni}, \mathrm{Zn}$, utilizando fatores de contaminação e índices de geoacumulação, constataram a ocorrência de interferências antrópicas como agrodefensivos e fertilizantes (BORGES, 2009).

Com o objetivo de evitar o aumento da deterioração da qualidade da água dos rios devido à produção industrial e a concentração urbana, é necessária uma política governamental, tanto no âmbito nacional quanto regional, para isso, são necessários estudos relacionados com a dinâmica fluvial e suas características, modelos hidrológicos, planejamentos e gestões de bacias hidrográficas que visem identificar impactos no equilíbrio do meio e através dele buscar alternativas de controle (SANTOS et al., 2007). 
Para Bruijnzeel (1997), esses modelos hidrológicos devem auxiliar no manejo de bacias hidrográficas, tanto para seu planejamento quanto para a avaliação do impacto de mudanças no uso da terra, para isso, é essencial descrever os processos aplicados em que os solos e a vegetação variem, e assim, auxiliem na determinação de qual uso da terra é possível.

O Estado de Goiás com sua localização privilegiada, compondo várias bacias hidrográficas, condições climáticas e topográficas, constitui um rico patrimônio ambiental. Por outro lado, essas características favorecem a implantação de grandes projetos agroindustriais e agropecuários, bem como a instalação de indústrias, hidrelétricas e mineração, resultando em um aumento considerável do consumo de água. Contudo, o cenário de tendências do estado goiano envolvendo ambiente, dinâmica demográfica, saúde, economia e investimentos apontam para a necessidade de um direcionamento voltado para ações que consolidem o desenvolvimento sustentável na região (GOIÁS, 2005).

\section{3 Índices Geoquímicos}

Considera-se a geoquímica o ramo que objetiva analisar e entender as relações entre os elementos químicos que compõem a litosfera. Capaz de refletir a influência de atividades humanas, exemplo disso são os recursos hídricos, que configuram como um ambiente propício a problemas ambientais (HERNÁNDEZ, 2008).

O estudo direcionado aos recursos hídricos tem como fundamento condicionar a qualidade ambiental e os indicadores geoquímicos como um meio de avaliações dessa qualidade. Pois se tratando de meio ambiente é indispensável realizar uma avaliação objetiva, com dados que comprovem os problemas de poluição, que estejam dentro de limites aceitáveis. Elementos químicos encontrados em uma determinada região podem ser considerados como normais para muitos ambientes, já em outros locais com os mesmos teores podem ser considerados altos, ou seja, sofre interferência da geologia local. O estudo que explica essas variações é denominado background geoquímico (GUEDES, 2012).

De acordo com Rodrigues et al.,(2009), o background químico é uma medida relativa usada para distinguir concentrações naturais de um dado elemento e a influência das atividades antrópicas nessas concentrações torna-se uma ferramenta essencial para avaliação por indicadores. Os métodos utilizados na determinação de seus valores são direto e indireto e os mais empregados são os diretos também chamados métodos geoquímicos, baseiam-se na análise de amostras consideradas naturais, ou seja, sem alterações e interferências antrópicas. 
Os métodos indiretos são reconhecidos também como método estatístico, que usa amostras estatísticas finitas para análises de diferentes elementos para verificar a interferência humana na área, a partir do todo ou parte do que foi mostrado.

Dentre os índices geoquímicos, os relevantes para a pesquisa são: Fator de contaminação e índice de geoacumulação. Esses índices são usados na análise de sedimento, empregando como valores de background a média da área de estudo. Para a análise de qualidade de água são usadas as técnicas multivariadas e análise fatorial. A análise fatorial é a correlação entre um conjunto inicial de variáveis e um conjunto menor de fatores comuns, que fundamentam nas inter-relações exibidas pelos dados originais, resultando em variáveis hipotéticas chamadas de índices de qualidade de água que esclarece a variância do conjunto original, que é dada pelo grau de correlação (BOLLMAN, 2003).

O Fator de acumulação (FA) verifica contaminações por deposição ou acúmulo de material na superfície do solo e independente da interferência antrópica ou natural. Em áreas com valores menores que um para o fator de acumulação $(F A<1,0)$, com concentrações maiores que o valor referencial mostra que a área encontra-se alterada com alguma atividade humana (JÚNIOR et al.,2008).

O Fator de contaminação (FC) dos sedimentos é calculado por meio da razão entre a concentração do elemento no sedimento e em background, possibilitando estabelecer o nível de enriquecimento ou empobrecimento do elemento no sedimento (HAKANSON, 1980; SOARES et al.,2004). O fator de acumulação foi proposto por Forstner (1983) que representa a relação entre a concentração do metal no sedimento, e sua concentração natural "background", segundo a equação:

$\mathrm{FC}=\mathrm{Cn} / \mathrm{Cbn}$

Fc: Fator de contaminação,

$\mathrm{Cn}$ : Concentração do metal " $\mathrm{n}$ ";

Cbn: Concentração de metal "n" do background.

O índice de geoacumulação proposto por Muller (1979) avalia a intensidade de contaminação dos sedimentos. Este índice fornece a relação entre teores de metas encontrados na região em análise e um valor referencial equivalente à média mundial para metais associados às argilas. $\mathrm{O}$ valor obtido permite classificar os níveis de enriquecimento dos metais, com intensidades de contaminação. Este índice é calculado por meio da fórmula:

$\mathrm{IGEO}=\log _{2}[(\mathrm{Cn} / 1,5 \mathrm{x} \mathrm{Cbn})]$ 
$\mathrm{Cn}$ : Concentração do elemento $\mathrm{n}$ na fração de argila $(<0,002 \mathrm{~mm})$ do sedimento a ser classificado; Cbn: Concentração média de "background" para argilas na crosta terrestre; 1,5: fator de correção para possíveis variações do “background"causado por diferenças litológicas.

\subsection{Fonte dos Elementos Químicos}

$\mathrm{O}$ cálcio $\left(\mathrm{Ca}^{2+}\right)$ é considerado o quinto elemento mais abundante com uma concentração média de 3,5\%. É o constituinte de minerais formados por rochas, como carbonatos, aluminossilicatos, sulfatos (WEDEPHOL, 1978). Tem importante função no solo: contribui para a formação da fertilidade, melhorando e capacitando a retenção de água no solo, estimula o desenvolvimento das raízes e contribui na fixação simbiótica de nitrogênio (LOPES, 1984, SERRAT, et al.,2002).

O magnésio $\left(\mathrm{Mg}^{2+}\right)$ é um elemento com número atômico 12. Constitui $2 \%$ da crosta terrestre e possui maiores concentrações em rochas máficas e ultramáficas do que em solos, podendo ser encontrado em vários minerais como Magnesita $\left(\mathrm{MgCO}_{3}\right)$, dolomita $\left(\mathrm{MgCO}_{3}\right)$ e carnalita $\left(\mathrm{MgCl}_{2}\right)$ (WEDEPOHL, 1978).

O alumínio $(\mathrm{Al})$ é um elemento metálico, número atômico 13, presente em grande quantidade na crosta terrestre, encontrado principalmente em silicatos, argilominerais, óxidos e hidróxidos. Durante o intemperismo favorece a incorporação de argilominerais e hidróxidos, porque possui baixa solubilidade (SANTOS, 1997, WEDEPHOL, 1978). Quando puro é mole e dúctil. O Al é muito utilizado no tratamento de esgotos e matérias de construção.

O ferro (Fe) é um metal de transição, número atômico 26, e suas principais fontes são os minérios hematita $\left(\mathrm{Fe}_{2} \mathrm{O}_{3}\right)$, magnetita $\left(\mathrm{Fe}_{3} \mathrm{O}_{4}\right)$, limonita $\left(\mathrm{FeO}(\mathrm{OH}) \mathrm{nH}_{2} \mathrm{O}\right)$, ilmennita $\left(\mathrm{FeTiO}_{3}\right)$, siderita $\left(\mathrm{FeCO}_{3}\right)$ e pirita $\left(\mathrm{FeS}_{2}\right)(\mathrm{MAIA}, 2003)$. É encontrado em rochas ultramáficas, argilitos marinhos e folhetos e o seu comportamento geoquímico relaciona-se com o oxigênio, enxofre e carbono (WEDEPOHL, 1948).

O silício ( $\mathrm{Si}$ ), número atômico 14 é um dos elementos mais abundantes na crosta terrestre, pertence ao grupo dos não metais, e ocorre em várias formas de óxido de silício e nos silicatos minerais. Sempre se associa com outros elementos, principalmente minerais como os argilominerais, que geralmente estão em suspensão na água.

O potássio $\left(\mathrm{K}^{+}\right)$é um elemento encontrado na crosta em concentrações variadas. Os granitos representam umas das principais fontes naturais de $\mathrm{K}$, através dos minerais feldspatos potássicos, micas e biotita. Ele é praticamente indisponível em águas naturais e sua 
capacidade de retenção em argilas contribui para o armazenamento desse nutriente tornando-o acessível ao consumo dos vegetais e colaborando no desenvolvimento da biota aquática.

$\mathrm{O}$ sódio $\left(\mathrm{Na}^{+}\right)$é um elemento químico metálico, reativo, com número atômico 11. Ele oxida no ar e reage bastante com a água, sendo encontrados em efluentes domésticos, produtos agrícolas e industriais.

$\mathrm{O}$ nitrato $\left(\mathrm{NO}_{3}^{-}\right)$é a principal forma de ocorrência de nitrogênio $(\mathrm{N})$ na água e associase à contaminação da água pelas atividades agropecuárias. Devido o ânion nitrato ser fracamente retido nas cargas positivas dos coloides, ele tende a permanecer nas camadas superficiais do solo, com o processo de lixiviação, atingindo os lençóis freáticos. O excesso de nitrato nos ambientes aquáticos ocasiona eutrofização favorecendo a proliferação exagerada de algas e plantas aquáticas (RESENDE, 2002).

A amônia $\left(\mathrm{NH}_{3}\right)$ é um composto químico relativamente abundante, tanto no ambiente terrestre, quanto em ambiente aquático. Em condições ambientais pode ser encontrada em estado gasoso, como resultado da decomposição aeróbia e anaeróbia da matéria orgânica. Esteves (1998) explica que a amônia no meio aquático especialmente quando o pH é ácido ou neutro, instável, sendo convertida por hidratação a íon amônio $\left(\mathrm{NH}_{4}{ }^{+}\right)$. Em meio alcalino favorece a ocorrência do aumento da concentração da forma não ionizada $\left(\mathrm{NH}_{3}\right)$. Assim o crescimento dos valores de $\mathrm{pH}$ e temperatura reduzem a toxicidade da amônia não-ionizada, principalmente os efeitos tóxicos da amônia total (REIS et al., 1997). Ocorre naturalmente como consequência da degradação de compostos orgânicos e inorgânicos presentes no solo e na água, excreção da biota, entre outros. A amônia é considerada um constituinte comum dos esgotos municipais como resultados de descarga de efluentes industriais e domésticos (UNESCO, 1992).

$\mathrm{O}$ sulfato $\left(\mathrm{SO}_{4}{ }^{2-}\right)$ é um dos íons mais abundantes na natureza. A origem dele se dá pela oxidação da pirita e a lixiviação de compostos sulfatados (evaporitos) como gipsita $\left(\mathrm{CaSO}_{4} \mathrm{H}_{2} \mathrm{O}\right)$ e a anidrita $\left(\mathrm{CaSO}_{4}\right)$. Surge nas águas subterrâneas por meio da dissolução de solos e rochas. Nas águas superficiais, ocorrem através das descargas de esgotos domésticos, efluentes industriais e da precipitação atmosférica decorrente de sais cíclicos e poeiras (GURGEL, 2007).

$\mathrm{O}$ cádmio $(\mathrm{Cd})$ é um metal de transição, sendo que os minerais típicos dele são greenockite $(\mathrm{CdS})$, octavite $\left(\mathrm{CdCO}_{3}\right)$. As associações naturais do cádmio são com o zinco, em 
todos os tipos de ocorrências, pode substituir o $\mathrm{Ca}^{2+}$ e o $\mathrm{Mn}^{2+}$ (REIMANN \& CARITAT, 1998).

O cobre é um elemento vestigial da crosta terrestre. É metal maleável, dúctil e muito resistente à corrosão, considerado o segundo metal com mais alta condutividade elétrica. Os minerais típicos do cobre são a calcopirite $\left(\mathrm{CuFeS}_{2}\right)$, a malaquite $\left(\mathrm{Cu}_{2} \mathrm{CO}_{3}(\mathrm{OH})_{2}\right)$, entre outros.Os principais usos são na indústria elétrica, bactericidas, fungicidas, corantes, entre outros (REIMANN \& CARITAT, 1998).

$\mathrm{O}$ zinco $(\mathrm{Zn})$ existe no estado de oxidação +2 , possui mobilidade elevada sob condições em meio ácido e muito baixa. As principais barreiras geoquímicas deste elemento são o $\mathrm{pH}$ e a adsorção pelas argilas, pelos óxidos de Fe-Mn e pela matéria orgânica. Os principais usos são na indústria da borracha, tinta, fungicidas, fertilizantes, construção civil (REIMANN \& CARITAT, 1998).

\subsection{Elementos Traço no Meio Ambiente}

Os metais são um dos principais poluentes encontrados, devido tanto à ação natural quanto ação antrópica. A ocorrência natural depende do tipo de rocha de origem do solo e a antropogênica depende das atividades urbanas, rurais e industriais realizadas sobre o solo.

Os elementos traços estão presentes naturalmente nos solos e sistemas aquáticos, agregando-se a associações químicas e físicas no ambiente natural. Sendo que o aparecimento natural do elemento traço no sistema aquático se da pelo intemperismo de rochas e a lixiviação no solo, enquanto as fontes antrópicas se dão por resíduos domésticos, atividades de mineração, industriais e despejos agrícolas. Estas interferências antrópicas excessivas ocasionam o aumento em sua composição, se tornando mais susceptíveis de ser assimilado pelos organismos (POMPÊO et al., 2013).

Elementos traço são elementos químicos que ocorrem no ambiente em pequenas concentrações e, distribuem-se nos sistemas aquáticos em forma de solução, acumulando-se diretamente nos sedimentos de fundo onde ocorre a união de partículas inorgânicas e orgânicas ou assimilação pelos micro-organismos. Apesar de alguns elementos serem essenciais aos seres vivos, em altas concentrações podem ser tóxicos. Isso ocorre devido ao acúmulo e transporte de elementos químicos que interagem com os demais elementos presentes no solo, gerando efeitos tóxicos que atingem os corpos hídricos e causam malefícios para os seres vivos (SILVA, 2006). A toxicidade dos elementos depende da sua 
disponibilidade, sendo determinada por sua forma de ligação específica (elementos presentes nas frações trocáveis, associada a carbonatos, matéria orgânica, dentre outros) (DOURADO, 2013).

Os elementos traço são divididos em macronutrientes $(\mathrm{Ca}, \mathrm{Cl}, \mathrm{Mg}, \mathrm{P}, \mathrm{K}, \mathrm{Na}, \mathrm{S})$ e micronutrientes $(\mathrm{Cr}, \mathrm{Cu}, \mathrm{F}, \mathrm{Mn})$. Normalmente se associam a silicatos e a minerais primários, apresentando baixa mobilidade, já aqueles incorporados por atividades antrópicas apresentam maior mobilidade e estão vinculados a carbonatos, óxidos e sulfetos. Os processos responsáveis pelo transporte destes elementos são adsorção, dessorção e precipitação que determinam o comportamento desses ambientes (PEREIRA et al., 2007).

A mobilidade destes elementos é definida pela facilidade que eles possuem para se mover em um determinado ambiente. É controlada por processos químicos e bioquímicos. As características físico-químicas das soluções como $\mathrm{pH}$, Eh (potencial redox), capacidade de troca catiônica (CTC), tamanho das partículas, matéria orgânica e argilas, influenciam a disponibilidade dos metais nos sedimentos. $\mathrm{O}$ pH se destaca como o mais importante, uma vez que interfere direta ou indiretamente em todos os fatores citados. De maneira geral, o aumento do $\mathrm{pH}$ reduz a disponibilidade desses constituintes para o curso d'água (CARVALHO, 1995).

Portanto, é importante monitorar os teores de metais nos compartimentos ambientais, uma vez que não são degradáveis e podem sofrer enriquecimento por bioacumulação na cadeia alimentar, desde plantas aquáticas e invertebrados até níveis tróficos mais elevados, podendo apresentar manifestações tóxicas. Exemplos disso são os elementos $\mathrm{Hg}$ e $\mathrm{Cd}$ que são sempre tóxicos independentes da sua quantidade, mas outros como $\mathrm{Fe}$ e $\mathrm{Zn}$, que são essenciais, mas em elevadas concentrações apresentam efeitos prejudiciais à saúde (ESTEVES, 1998).

\subsection{Influência das Atividades Antrópicas sobre a Qualidade de Água}

O ambiente físico representa a interação dos componentes físicos da natureza, como clima. topografia, rochas, águas, vegetação e solos. É um sistema natural, com dinâmica e mecanismos próprios. Mas o ser humano é parte integrante da natureza, de sua evolução e transformação (BORSATO et al.,2004). Porém a ação antrópica pode afetar seu equilíbrio e sua dinâmica através de intervenções e alterações sucessivas, as quais desencadeiam impactos, principalmente em decorrência do aumento populacional. 
As atividades do homem, visando atender as exigências crescentes de demanda demográfica, necessitam de uma maior produtividade agrícola, sendo responsável por impactos geoquímicos no ambiente. Isso ocorre pela adição de fertilizantes para suprimento de carências específicas em micro e macronutrientes, pelo uso de calcário que visa a neutralização do pH e imobilização do Alumínio (Al), e pelo uso de agrotóxicos clorados, fosforados, mercuriais e entre outros, para o controle e eliminação de pragas, que visam acelerar a colheita e preservação dos produtos armazenados (LICHT, 2001).

De acordo com Allan (1995), qualquer ação antrópica nas bacias promove variáveis que a geologia dos rios não consegue controlar. Tucci et al., (2002) reforçam que as ações antrópicas além de comprometer determinadas áreas afetadas, tem impactos significativos sobre o escoamento, ocasionados pelo desmatamento através da extração de madeira.

Silva et al. (2010) verificaram em seu estudo as principais intervenções antrópicas que influenciem parâmetros $(\mathrm{pH}$, condutividade, total de sólidos dissolvidos, metais e elementos traços), a fim de avaliar a qualidade de água na bacia do Rio São Francisco. Eles constataram que as atividades antrópicas tem influenciado na menor qualidade de algumas áreas do rio São Francisco.

Os efeitos das atividades antrópicas se diferem para cada local, pois depende de uma série de fatores biogeoquímicos. As formas mais comuns de uso e contaminação dos recursos hídricos baseiam-se em abastecimento público, agricultura e pecuária, entre outros.

Holt (2000) e Tucci et al., (1997) salientam que se por um lado com o desenvolvimento urbano e rural favorecem à industrialização e a urbanização, porém resultam no aumento da demanda da água e dos índices de contaminantes nos corpos d'água, atingindo os mananciais. Essa contaminação ocorre principalmente por fatores como esgotos domésticos e industriais, uso de fossa séptica que contamina o lençol freático, perfuração de poços sem cuidados específicos para evitar a ligação entre camadas do subsolo, uso de fertilizantes e agrotóxicos na agricultura, localização de depósito de lixo, despejos e descargas industriais próximos a efluentes, entre outros.

De acordo Bolmann et al., (2003) uma importante fonte de poluição do meio aquático são as águas pluviais, pois durante esse período chuvoso a quantidade de poluentes atingem níveis altos, pois o escoamento da água durante a chuva carrega materiais orgânicos e inorgânicos aos mananciais destacando o esgoto doméstico. Esse fator é desencadeado pela má distribuição espacial, falta de limpeza urbana e intensidade de precipitação. Vale ressaltar 
que o escoamento superficial, em bacias com topografia acentuada, exploradas por agricultura intensiva apresenta grande gasto de energia para desintegrar o solo e assoreá-los aos corpos hídricos (TOLEDO e FERREIRA, 2000).

Os processos de degradação ambiental tem se acentuado, em consequência do crescimento das cidades e práticas inadequadas de uso do solo, e que, de certo modo, refletem a forma como a sociedade se apropria da natureza e da água como recurso natural. Além desses fatores, as variações climáticas tem contribuído para a aceleração desse processo, o que tem levado muitos estudiosos a especular sobre uma possível escassez hídrica em curto período de tempo.

Entretanto, as alterações espaciais e ambientais causadas pela ocupação urbana devem levar o homem a compreender o meio em que vive e como ele é transformado, interpretando assim os processos que o deflagram e os impactos produzidos, a fim de conduzir suas ações a uma gestão que considere o cenário atual e futuro dos recursos naturais (VALETIM, 2010).

A pecuária é muito importante para economia brasileira, mas causa impactos ao meio ambiente, tais como degradação do solo, poluição dos recursos hídricos e destruição dos ecossistemas ambientais (HOLANDA et al.,2009). As principais causas de contaminação ocorrem devido a dejetos de animais que contêm minerais e matéria orgânica, essas excreções podem ainda ter organismos patogênicos que atingem rios ou mananciais de água podendo causar doenças na população (SEGRANFREDO et al., 2003).

Exemplo dessa contaminação foi salientado por SEGRANFREDO et al., (2003) como os dejeitos suínos despejados em cursos d'água, acarretando poluição no corpo hídrico.

Diversas causas podem comprometer o meio ambiente, contudo a introdução de gado nos lotes reduz a porosidade da superfície e aumenta a densidade diminuindo a capacidade de infiltração e aumentando os volumes de escoamento superficial. No escoamento superficial os principais nutrientes encontrados são $\mathrm{K}, \mathrm{N}, \mathrm{P}, \mathrm{Na}$ e $\mathrm{Si}$ são encontrados no escoamento subsuperficial. A avicultura também apresenta suma importância na poluição, pois a água é usada como meio de introduzir vacinas e medicação para as aves podendo desencadear alterações na composição da água (MOREIRA et al., 2003).

De acordo com Carmo (2005), as práticas agrícolas comprometem a qualidade da água de bacias hidrográficas, principalmente aquelas destinadas ao abastecimento público, sendo que as principais causas são o uso indiscriminado de fertilizantes e agrotóxicos em áreas de atividades agrícolas e o despejo de efluentes domésticos. Destacam-se os elementos Mn, Zn e 
$\mathrm{Cu}$ provenientes de fertilizantes utilizados na agricultura em Campo Alegre de Goiás. Sendo assim, esses passam a ser parâmetros importantes para verificação do comprometimento da qualidade de água que abastece a cidade.

Rangel (2008); Ramalho et al., (2000); Ferreira et al., (2006) demonstram que o uso de agrotóxico representa um risco para a qualidade da água principalmente aquelas próximas à regiões agrícolas. Então, esse recurso hídrico contaminado, quando utilizado para consumo humano, torna-se importante objeto de estudo da pesquisa científica pelos seus efeitos nocivos à saúde humana e à qualidade de vida ambiental (VEIGA et al., 2006). A cinética dos agrotóxicos permite visualizar o dinamismo do transporte e a disponibilidade de elementos químicos no ambiente. No entanto, depende não só das suas concentrações, mas de suas associações químicas e físicas nos sistemas naturais, influenciados pelas condições ambientais, intemperismo natural e ou antrópicas (CARVALHO, 2009).

\subsection{Intemperismo}

O intemperismo é o resultado dos diversos elementos na atmosfera, especificamente, da água, do oxigênio, do gás carbônico e da temperatura sobre as rochas. É considerado também um processo que permite o desenvolvimento de novos minerais a partir daqueles alterados (SARDINHA, 2011). Os processos de intemperismo consistem em modificações físicas (desagregação) e químicas (decomposição) dos minerais, das rochas em si na superfície terrestre em resposta as condições oferecidas pelo ambiente, podendo ser causado por processos físicos, químicos e biológicos. Quando as rochas são expostas a determinadas condições perdem o equilíbrio, surgindo no ambiente superficial uma resposta para novamente estabilizá-la (MICHELON, 2006).

A disponibilidade e distribuição dos elementos químicos não dependem somente de suas concentrações, mas de relações químicas e físicas nos ambientes naturais e/ou ações antrópicas. Assim, é essencial conhecer as condições naturais e a ação no intemperismo para correlacionar com as atividades humanas (ECHEVERRIA, 2006). O intemperismo são todos os processos de destruição e reconstrução que ocorrem na superfície da Terra. Podem ser distinguidos três tipos: físico, químico e biológico.

Os processos físicos são aqueles que causam apenas a fragmentação sem que ocorram modificações químicas e mineralógicas no material original. A desintegração aumenta a superfície reativa, facilita a decomposição das rochas por meio de reações químicas com a 
água, com o oxigênio livre e dióxido de carbono. Todos estes contribuem para a deterioração de materiais geológicos (MORTATTI, 2003).

O intemperismo químico ocorre quando o equilíbrio do conjunto de átomos, que constitui os minerais é rompido e reações químicas que conduzem o mineral a um arranjo estável, transformam os minerais primários em minerais secundários. Esse processo depende da presença de água, de sólidos e gases dissolvidos esses relacionam com o transporte de material dissolvido pelos corpos hídricos, tendendo a um aprofundamento do perfil de alteração do solo (SARDINHA, 2011). O principal agente do intemperismo químico é a água que, absorvendo o $\mathrm{CO} 2$ da atmosfera, adquire características ácidas. Os principais tipos de reações químicas associadas ao intemperismo são: hidratação, hidrólise, oxidação e dissolução.

A hidratação implica na adsorção de água na estrutura cristalina do mineral, podendo alterá-lo. Como exemplo tem-se: $\mathrm{Fe}_{2} \mathrm{O}_{3}$ (hematita) que com adição de $2 \mathrm{FeO}(\mathrm{OH})$ transformase em goethita. Na hidrólise ocorre decomposição de um mineral por meio da presença de uma solução aquosa levemente ácida, ou seja, é uma reação química entre íons de $\mathrm{H}^{+}$ (ionização da $\mathrm{H}_{2} \mathrm{O}$ ) e cátions do Mineral (ph entre 5 a 9). $\mathrm{O} \mathrm{H}^{+}$entra nas estruturas dos minerais deslocando cátions (solução), combinando com alcalinos fazendo com que sua estrutura se rompa, assim faz com que haja uma maior percolação de $\mathrm{H}_{2} \mathrm{O}$ (BONOTTO, 2011).

A dissolução ocorre em solubilização de alguns minerais por ácidos. O cátion de hidrogênio é o principal fator responsável pela dissolução dos minerais, pois rompe a estrutura cristalina do mineral e substitui o cátion antes presente no mineral. Como por exemplo, tem-se a dissolução da calcita $\left(\mathrm{CaCO}_{3}\right)$ na reação: $\mathrm{CaCO}_{3}+\mathrm{HCO}_{3}=\mathrm{Ca}^{2}+2 \mathrm{HCO}_{3}$

As reações de oxidação ocorrem em ambientes aerados da zona de intemperismo pela ação dos agentes de oxidação. Os minerais formados em ambientes deficientes em oxigênio são convertidos em compostos de valência mais elevada. Muitos minerais contêm ferro na sua constituição que reage com o oxigênio, ou seja, ele é facilmente oxidado passando de ferroso a férrico (MULHOLLAND, 2009). O intemperismo biológico ocorre através dos seres vivos, onde estes desempenham de forma direta ou indireta o intemperismo nas rochas. É produzido pelas bactérias, produzindo a decomposição biótica de materiais orgânicos. Este tipo de intemperismo produz solos férteis (BONOTTO, 2011). 


\section{CAPÍTULO 4}

METODOLOGIA

\subsection{Escolha dos pontos}

As amostras de água e sedimentos utilizados nesse trabalho foram coletadas no córrego Campo Alegre. A definição da localização dos pontos das amostragens na Bacia do Córrego Campo Alegre foi através de visualizações de imagens de satélite do software Google Earth Professional. A interpretação das imagens seguiram padrões de cores, textura e formatos, que indicaram ocupações e usos da área. A localização desses pontos em campo foi realizada com um GPS modelo Garmin 45XL. A área escolhida como controle ambiental foi o ponto 1, (Figura 4.1e Tabela 4.1) área da nascente do Córrego Campo Alegre, que supostamente está isenta de contaminações provenientes de atividades antrópicas devido à sua localização, sendo assim considerada Background em valores referência para o trabalho.

\subsection{Amostragem}

As coletas para análises químicas foram realizadas durante estação seca (agosto de 2013) e estação chuvosa (março de 2014) em pontos definidos, levando em consideração a localização do córrego, de jusante a montante. Foram selecionados 17 pontos de coleta de amostra de água e 14 pontos de coleta de sedimento em pontos estratégicos na bacia do córrego Campo Alegre (Figura 4.2). Para os pontos 15 e 16 foram coletados somente dados de água por estar dentro da estação de tratamento, (ponto do tanque e da torneira), isentos de sedimentos. Após a coleta, as amostras foram analisadas no Laboratório de geoquímica do Instituto de Geociências da Universidade de Brasília (LAGEO/UnB). 


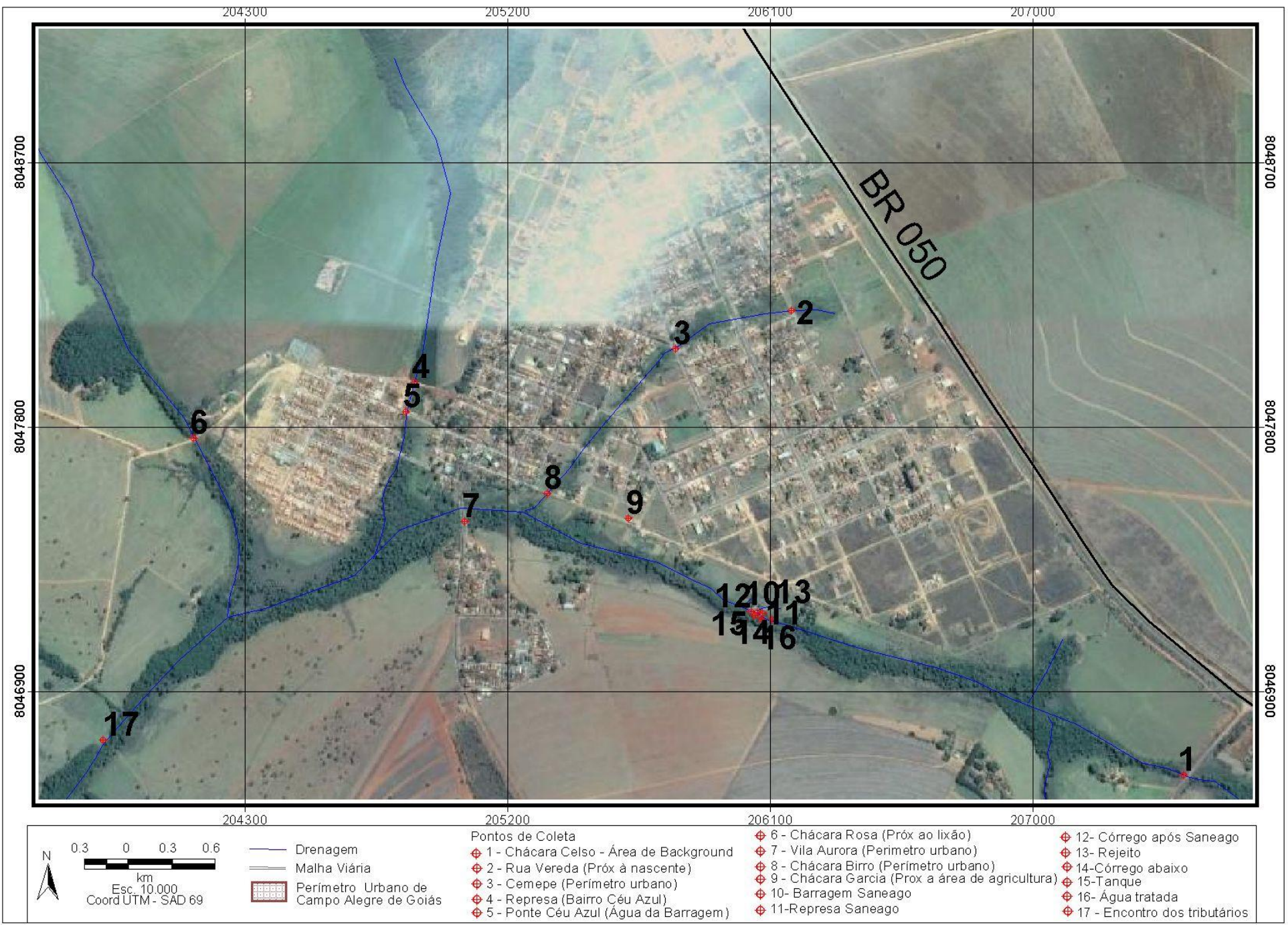

Figura 4.1 - Mapa de pontos de coleta de água e sedimento. 
Tabela 4.1 - Pontos de amostragem usados neste trabalho.

\begin{tabular}{|c|c|c|}
\hline Pontos de coleta & Descrição & Coordernadas UTM \\
\hline P1 - Chácara Celso & $\begin{array}{l}\text { Local de área preservada, } \\
\text { nascente do córrego Campo } \\
\text { Alegre. (Background) }\end{array}$ & 0207015 E / $8046706 \mathrm{~S}$ \\
\hline P2 - Rua Vereda & $\begin{array}{l}\text { Próximo a nascente, vegetação, } \\
\text { presença de peixes. }\end{array}$ & $0205880 \mathrm{E} / 8048120 \mathrm{~S}$ \\
\hline P3 - Cemepe & $\begin{array}{l}\text { Área de perímetro urbano, } \\
\text { utilizada para consumo de } \\
\text { ribeirinhos. }\end{array}$ & $0205511 \mathrm{E} / 8047985 \mathrm{~S}$ \\
\hline P4 - Represa & $\begin{array}{l}\text { Bairro Céu Azul. Diferentes } \\
\text { tributários se juntam. }\end{array}$ & 0204703 E / 8047858S \\
\hline P5 - Ponte & $\begin{array}{l}\text { Barragem da represa, perímetro } \\
\text { urbano, pouca vegetação e área } \\
\text { de lazer da população. }\end{array}$ & 0204676 E / 8047765 S \\
\hline P6 - Chácara Rosa & $\begin{array}{l}\text { Próximo ao Lixão, área próxima } \\
\text { a agricultura. Provável } \\
\text { contaminação }\end{array}$ & 0204004 E / 8047676 S \\
\hline P7 - Vila Aurora & $\begin{array}{l}\text { Perímetro Urbano, área próxima } \\
\text { a agricultura, água turva }\end{array}$ & $0204877 \mathrm{E} / 8047398 \mathrm{~S}$ \\
\hline P8 - Chácara Birro & $\begin{array}{l}\text { Perímetro Urbano, presença de } \\
\text { resíduos domésticos, restos } \\
\text { mortais de animais. }\end{array}$ & $0205126 \mathrm{E} / 8047520 \mathrm{~S}$ \\
\hline P9 - Chácara Garcia & $\begin{array}{l}\text { Beira do Córrego. Abaixo da } \\
\text { SANEAGO, área próxima a } \\
\text { agricultura. }\end{array}$ & $0205254 \mathrm{E} / 8047324 \mathrm{~S}$ \\
\hline P10- Barragem SANEAGO & $\begin{array}{l}\text { Água utilizada para tratamento, } \\
\text { SANEAGO }\end{array}$ & 0205855E / 8047143S \\
\hline P11-Represa SANEAGO & $\begin{array}{l}\text { Água utilizada para tratamento, } \\
\text { SANEAGO }\end{array}$ & $0205872 \mathrm{E} / 8047122 \mathrm{~S}$ \\
\hline P12- Córrego após SANEAGO & $\begin{array}{l}\text { Córrego que deságua da } \\
\text { barragem, percurso comum do } \\
\text { córrego }\end{array}$ & 0205773 E / $8047144 \mathrm{~S}$ \\
\hline P13- Rejeito & $\begin{array}{l}\text { Local de despejo de água } \\
\text { utilizada para lavagem do } \\
\text { Tanque de tratamento. }\end{array}$ & $0205750 \mathrm{E} / 8047161 \mathrm{~S}$ \\
\hline P14-Córrego abaixo & $\begin{array}{lcrr}\text { Córrego } & \text { após } & & \text { represa } \\
\text { SANEAGO. } & \text { Ainda } & \text { se } & \text { encontra }\end{array}$ & 0205728 E / $8047166 \mathrm{~S}$ \\
\hline
\end{tabular}




\begin{tabular}{lll}
\hline \multicolumn{1}{c}{ Pontos de coleta } & \multicolumn{1}{c}{ Descrição } & \multicolumn{1}{c}{ Coordernadas UTM } \\
\hline & nas instalações da empresa. & \\
P15-Tanque & $\begin{array}{l}\text { Água em tratamento } \\
\text { Água para consumo, após }\end{array}$ & $0205759 \mathrm{E} / 8047190 \mathrm{~S}$ \\
P16- Água tratada & $\begin{array}{l}\text { tratamento } \\
\text { Local de encontro de todos os } \\
\text { tributários }\end{array}$ & $0203828 \mathrm{E} / 8046770 \mathrm{~S}$ \\
P17 Final &
\end{tabular}
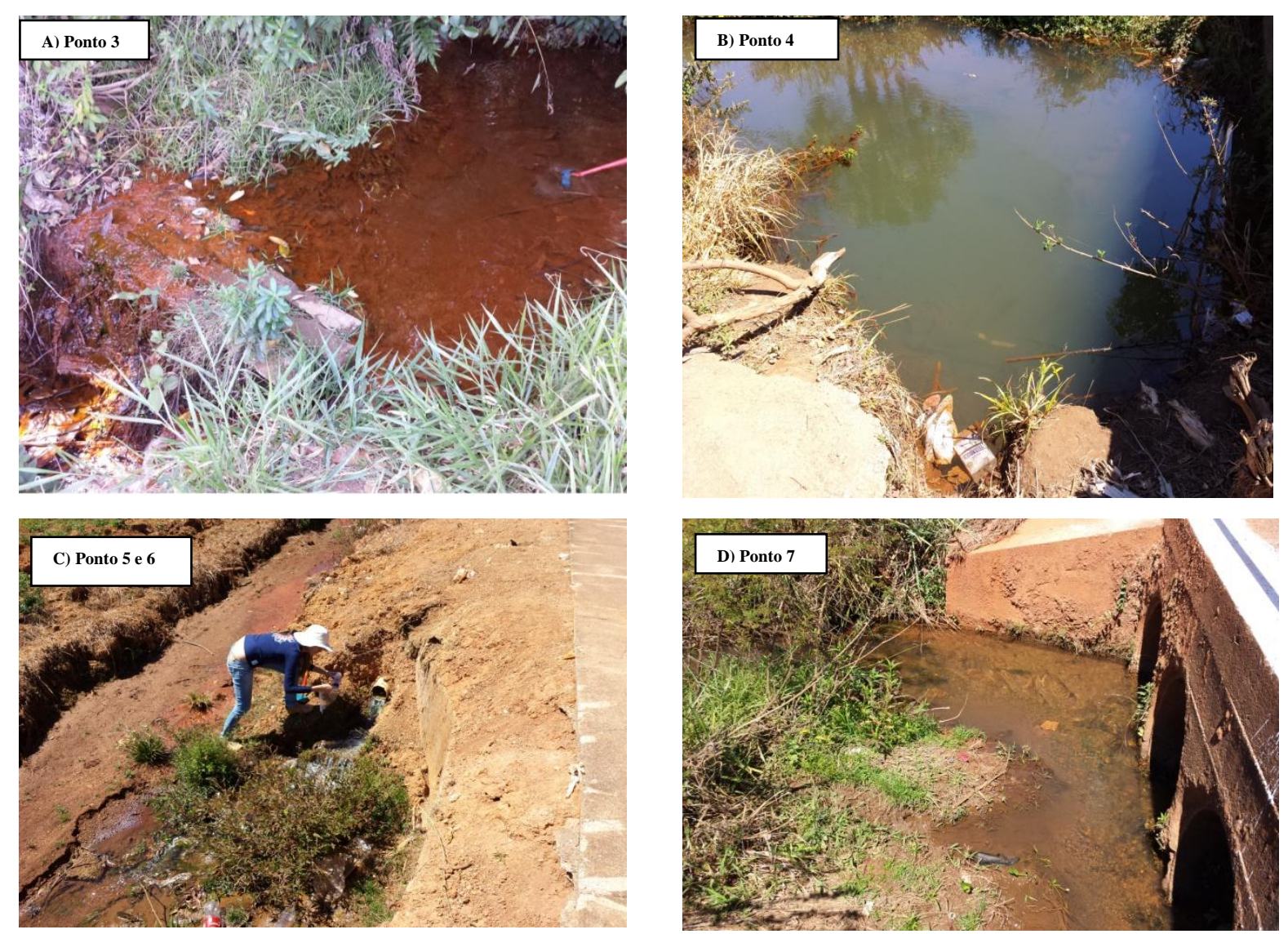

Figura 4.2 - Imagens dos diferentes aspectos dos locais de coleta. Em A) tem-se o Ponto 3-ponto zona rural com presença de restos de animais e fezes dos mesmos. Em B) foi feita a coleta do Ponto 4, água com aspecto turvo dentro do perímetro urbano com grande presença de lixo nas encostas. Em C) coletou-se o Ponto 5 e 6 , ponto de encontro entre duas nascentes, que é uma área com presença de resíduos domésticos situação no Bairro Céu Azul e em D) Ponto 7 ponto no Bairro Vila Aurora, com presença de mata ciliar e lixos

Para a coleta das amostras de água foram utilizados frascos de polietileno de $1 \mathrm{~L}$ previamente identificados, lavados com ácido nítrico $10 \%$ e com água obtida por sistema de purificação MilliQ (resistividade de $18,2 \mathrm{M} \Omega \mathrm{cm}^{-1}$ a $25^{\circ} \mathrm{C}$ ). No momento da coleta, os frascos foram ambientados com a mesma água da amostra coletada e depois foram acondicionadas sobrefrigeração em caixas térmicas e enviadas ao laboratório. Duas frações de $50 \mathrm{~mL}$ das amostras foram filtradas e acondicionadas em dois frascos de centrífuga de $50 \mathrm{~mL}$ utilizando membranas em ésteres de celulose com poro de 0,45 $\mu \mathrm{m}$ Milipore. Uma das frações foi acidificada com 
ácido nítrico suprapur ${ }^{\circledR}$ Merck com $\mathrm{pH}<2$ para análise de metais. A outra fração foi reservada para análise dos ânions e ambas foram refrigeradas a $4{ }^{\circ} \mathrm{C}$.

As amostras de sedimento foram coletadas com o auxílio de uma pá de PVC recolhendose aproximadamente $500 \mathrm{~g}$ de cada, em locais respectivos às coletas de água, onde o sedimento se encontrava ativo no leito do rio. Em seguida foram acondicionadas em sacos de polietileno e identificadas com local e coordenadas geográficas

\section{3 - Análise de água}

\subsubsection{Determinação de parâmetros físico- químicos}

$\mathrm{O} \mathrm{pH}$, a condutividade elétrica e o TDS foram determinados no campo utilizando um multiparâmetro portátil da Hach, série Sension, previamente calibrados com as respectivas soluções padrões.

A determinação do $\mathrm{CO}_{2}$ livre se deu por meio de titulação com $\mathrm{Na}_{2} \mathrm{CO}_{3} 0,04 \mathrm{~N}$ até pH 8,3 e indicador fenolftaleína, empregando o seguinte cálculo:

$$
\mathrm{CO}_{2}\left(\mathrm{mg} \mathrm{L}^{-1}\right)=\mathrm{V}_{\text {titulado }} \times 0,04 \times 22000 \times \mathrm{V}_{\text {amostra }}{ }^{-1} \text {. }
$$

\subsubsection{Determinação dos ânions}

Foram determinados os ânions fluoreto, cloreto, nitrato, fosfato e sulfato utilizando um aparelho de cromatografia iônica (IC) da marca Dionex modelo ICS90. Características do sistema utilizado: fluxo isocrático de eluente $\mathrm{Na}_{2} \mathrm{CO}_{3}: \mathrm{NaHCO}_{3} 3,5: 1 \mathrm{mM}$ a $1,2 \mathrm{~mL} \mathrm{~min}{ }^{-1}$ e pressão aproximada de 1500 psi; volume de injeção de $25 \mu \mathrm{L}$ definido por alça de amostragem; detector de condutividade suprimida modelo CS5; coluna e pré-coluna do tipo troca iônica com superfície funcionalizada de alquil amônio quaternário, modelos AS14A e AG14A, respectivamente; supressor de condutividade modelo AMMS-300 regenerado com $\mathrm{H}_{2} \mathrm{SO}_{4} 50$ $\mathrm{mM}$.

A alcalinidade foi determinada por método titulométrico de análise com $\mathrm{H}_{2} \mathrm{SO}_{4} \quad 0,02 \mathrm{~N}$ padronizado previamente com $\mathrm{NaOH} 0,05 \mathrm{~N}$, utilizando um titulador automático da marca Schott, modelo Titroline easy. A partir do cálculo: $\mathrm{HCO}_{3}^{-}\left(\mathrm{mg} \mathrm{L}^{-1}\right)=\mathrm{V}_{\text {ácido }} \mathrm{X} \mathrm{M}_{\text {ácido }} \mathrm{x} 61000$ $\mathrm{xV}_{\text {amostra }^{-1}}$

$\mathrm{O}$ íon amônio $\left(\mathrm{NH}_{4}{ }^{+}\right)$foi medido pelo método colorimétrico com leitura direta no 
aparelho Hach modelo DR2000 a 425 nm, utilizando kits de reação para amônia (Mineral Stabilizer, Alcool polivinílico e reagente de Nessler).

\subsubsection{Determinação dos metais em água}

Determinou-se o elemento $\mathrm{Na}(589,00 \mathrm{~nm})$ e K $(766,49 \mathrm{~nm})$ em sedimento de fundo por Espectrofometria de Absorção Atômica (EAA) em espectrofotômetro, marca Perkin Elmer, modelo Analyst 200 e fonte de excitação chama de ar- acetileno na proporção de 10: 2,5 L min ${ }^{1}$. A fenda utilizada foi de $1,8 \mathrm{~mm}$ de altura x $0,6 \mathrm{~mm}$ de largura (slit $\left.=600 \mu \mathrm{m}\right)$.

As análises dos elementos maiores e traços foram realizadas no Espectrômetro de Emissão Atômica com Plasma indutivamente acoplado (ICP/OES), marca Perkin Elmer e modelo Spectroflame-Fvmo3 com nebulizador Meinhard (Figura 4.3). O plasma foi mantido pelo gás argônio qualidade industrial a um fluxo principal de $1 \mathrm{~L} \mathrm{~min}^{-1}$, fluxo auxiliar de $0,6 \mathrm{~L}$ $\min ^{-1}$ e fluxo para resfriamento de $13 \mathrm{~L} \mathrm{~min}^{-1}$, (Tabela 4.2).

Foram usadas as seguintes linhas espectrais: $\mathrm{Ca}(317,93 \mathrm{~nm}), \mathrm{Mg}(279,88 \mathrm{~nm}), \mathrm{Fe}(259,95$ $\mathrm{nm}), \mathrm{Si}(251,61 \mathrm{~nm}), \mathrm{Al}(308,21 \mathrm{~nm}), \mathrm{Be}(313,04 \mathrm{~nm}), \mathrm{Sr}(407,77 \mathrm{~nm})$, Mo $(281,61 \mathrm{~nm}), \mathrm{Cd}$ (228,80 nm), Ti (334,94 nm), V (311,07 nm), Ni (231,60 nm), Zr (339,20 nm), Cu (324,75 nm), Cr (267,72 nm), Mn (257,61 nm), Ba (233,53 nm), Co (228,62 nm) e Zn (213,86 nm).

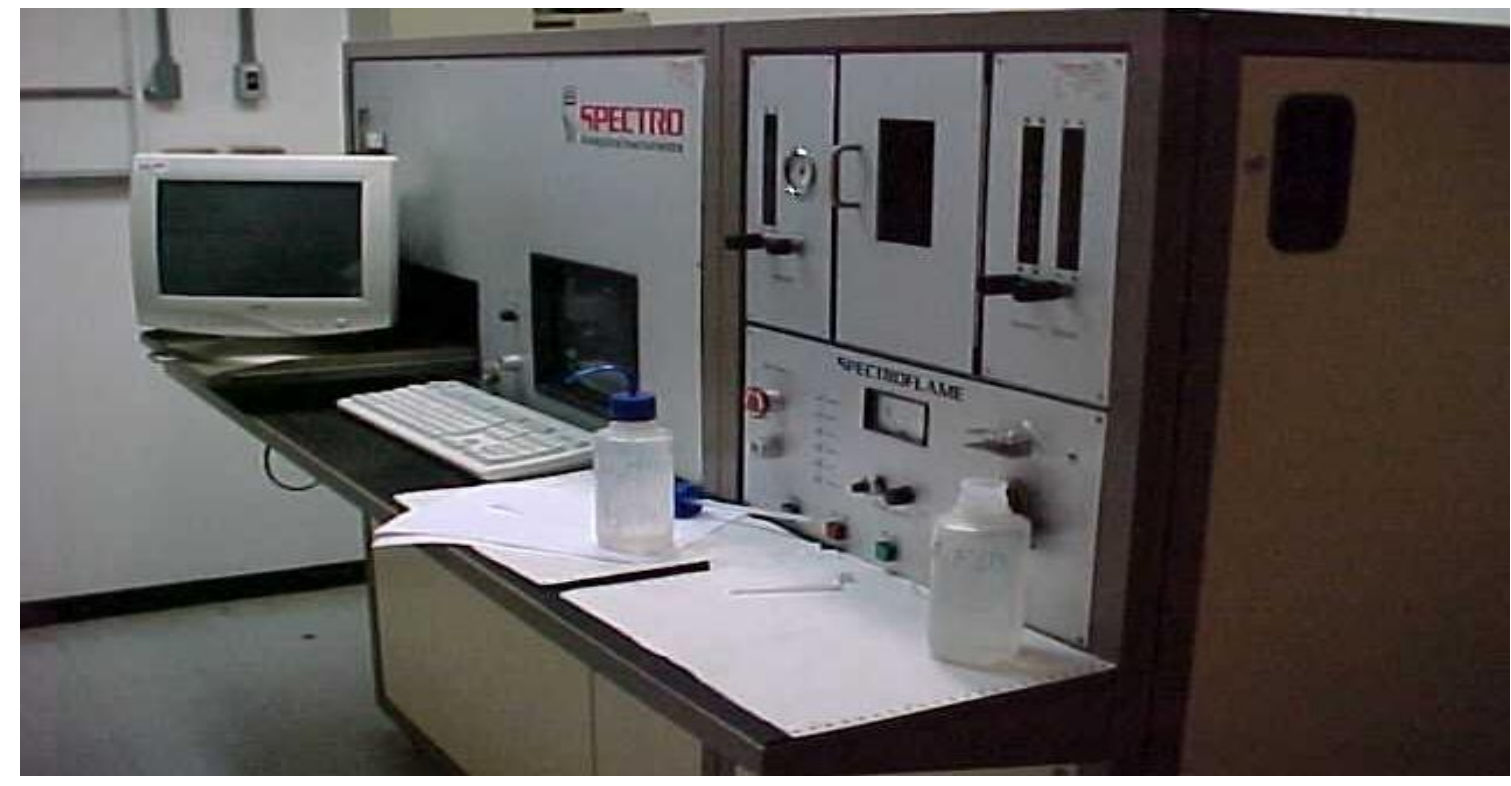

Figura 4.3 - Espectrômetro de Emissão Atômica com Plasma Indutivamente Acoplado (ICP/OES, IG/UnB). 


\subsection{Análise de Sedimento}

\subsubsection{Decomposição das amostras de sedimentos}

A coleta de cada ponto foi próximo à margem do tributário (cerca de 500g) utilizando pá de PVC. Em seguida, os sedimentos foram acondicionados em sacos plásticos e transportados para o laboratório. As amostras foram colocadas em bandeja de polietileno coberta com papel e submetida à secagem, em temperatura ambiente, até que toda água fosse evaporada (ECHEVERRIA 2007). Após a secagem, as amostras foram desagregadas e peneiradas. A parte peneirada foi utilizada para análises químicas e avaliação mineralógica.

A fração para retirar pedregulhos, plantas e determinar os elementos químicos e sólidos voláteis foi menor que $63 \mu \mathrm{m}$. De acordo Boaventura (1991) para determinar os elementos traços, as amostras devem ser submetidas a uma digestão ácida que permite liberar átomos da matéria orgânica, que consiste em uma "abertura" com $\mathrm{HF} / \mathrm{HNO}_{3} / \mathrm{HClO}_{4} / \mathrm{HCl}$ usando-se um fator de diluição de 50x, (Figura 4.4). Para os elementos maiores (Al, Fe, Si, Ca, Mg, Ti) foi utilizada a fusão com metaborato de lítio (Figura 4.5)

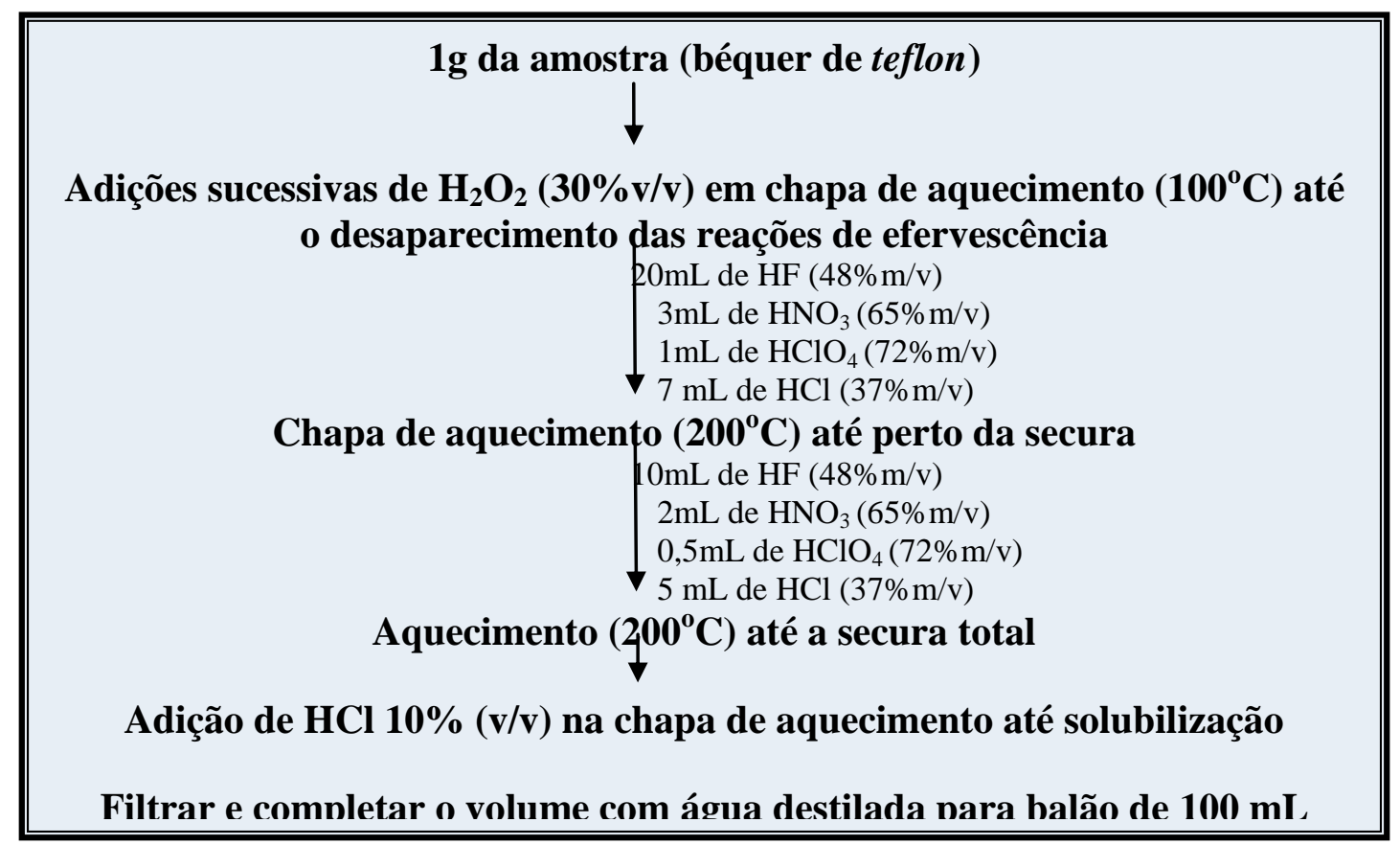

Figura 4.4 - Procedimento para abertura ácida das amostras de sedimento. 
Pesar $0,05 \mathrm{~g}$ de amostra $+\mathbf{0 , 1 7} \mathrm{g}$ de metaborato de lítio no cadinho de platina

Homogeneizar a mistura usando umarespátula e levar ao forno Mufla a 950

${ }^{\circ} \mathrm{C}$ por 30 min

Desligar o forno após 15 min e retirar os cadinhos para uma placa de
porcelana

Dissolver em béquer (250 mL) 200 de $\mathrm{HCl} 10 \%$ com suave aquecimento $\left(50^{\circ} \mathrm{C}\right)$

Transferir para um balão de $500 \mathrm{~m}$ L com água destilada e completar o volume

Homogeneizar a solução e transferír para um frasco plástico $(250 \mathrm{~mL})$

Figura 4.5 - Etapas realizadas para fusão de amostras de sedimento.

\subsubsection{Determinação dos Metais em Sedimento}

Para verificação da metodologia aplicada à análise dos sedimentos de fundo, verificar o item 4.3.3, uma vez que foram utilizados os mesmos métodos.

\subsubsection{Sólidos Voláteis em sedimento}

A determinação do teor de sólidos voláteis ocorreu por gravimetria. As alíquotas de $1 \mathrm{~g}$ das amostras foram pesadas na balança Meltler modelo AE 163. Para tanto, foram utilizados cadinhos de porcelana com massa conhecida. Em seguida, foram levadas ao forno mufla a uma temperatura de $500{ }^{\circ} \mathrm{C}$ e depois elevada para $1000{ }^{\circ} \mathrm{C}$ por $1 \mathrm{~h}$. Após isso os cadinhos foram resfriados no dessecador e pesados. Os valores de sólidos voláteis foram obtidos em função da perda de massa e, para isso, o procedimento foi repetido até que a diferença dos dois últimos pesos fosse menor que 0,001 g (APHA, 2008).

\subsubsection{Análise mineralógica por Difratometria de raios $-X$}

As determinações de raios- $\mathrm{X}$ foram executadas no laboratório de difratometria em raios- 
$\mathrm{X}$, para análises mineralógicas das frações $<0,045 \mathrm{~mm}$.

As amostras foram prensadas na lâmina e encaminhadas à leitura. A análise consistiu em duas varreduras distintas: uma amostra total (AT) e uma da fração argila orientada e seca ao ar (FF), aparelho utilizado foram Rigaku (modelo Ultima IV), operando com tubo de cobre com $35 \mathrm{kV}$ e $15 \mathrm{~mA}$, com velocidade de varredura $2^{\circ}$ /minuto. $\mathrm{O}$ intervalo de medida $0.05^{\circ} \mathrm{e}$ intervalo de varredura de 2 a $35^{\circ}$. As interpretações dos difratogramas e identificações dos minerais ocorreram no mesmo laboratório e para isso, utilizou-se o software JADE 3.0 para Windows, XRD Pattern Processing for the PC, 1991-1995 Materials Data, Inc.

\subsection{Controle analítico dos dados}

As metodologias utilizadas nas análises químicas foram baseadas no Standard Methods forthe Examination of Water and Wastewater; $20^{\mathrm{a}}$ edição da American Public Health Association (APHA),da American Water Works Association (AWWA), e da Water Pollution Control Federation (WPCF).

As curvas de calibração do EAA, ICP e IC foram preparadas com soluções padrões de 1000 ppm da marca Vetec e diluídas para cada elemento. O controle analítico dos resultados foi validado por amostras de padrão internacional de concentração conhecida. Para água, foram utilizados os padrões da marca Canadá NWRI (National WaterResearch Institute) ION915 e PERADE, lotes 0310 e 1109, respectivamente (Tabela 4.2 e 4.3). Também foram usados como parâmetro a água destilada e os dados obtidos da água da torneira, cujo acompanhamento é feito pelo Laboratório de Geoquímica da Universidade de Brasília desde 2008. Para análise de sedimentos, foi usado o padrão da NIST (National Institute for Standards and Technology - USA) SEM 2709a San Joaquin Soil. Para aferição da metodologia de digestão e análise, foi utilizado um padrão C de rocha basalto (Tabela 4.4). Os parâmetros de validação: limite de detecção (LD), limite de quantificação (LQ), coeficiente de regressão e faixa linear de trabalho foram calculados a partir de cinco leituras das curvas de calibração respectivas (Tabela 4.5). O limite de quantificação (LQ) considerado foi 10x o limite de detecção (LD). 
Tabela 4.2- Resultados obtidos para o padrão ION915.

\begin{tabular}{|c|c|c|c|}
\hline & \multicolumn{3}{|c|}{ PARÂMETROS } \\
\hline & Valor Esperado & $\begin{array}{l}\text { Resultado Obtido } \\
\left(\text { média } \pm t_{a / 2} * d^{*} n^{-1 / 2}\right)\end{array}$ & $\mathrm{CV}^{-\mathrm{c}}(\%)$ \\
\hline $\mathrm{Ca}\left(\mathrm{mg} / \mathrm{L}^{-1}\right)$ & 13,40 & $13,20 \pm 0,70$ & 1 \\
\hline $\operatorname{Mg}\left(\mathrm{mg} / \mathrm{L}^{-1}\right)$ & 2,80 & $2,7 \pm 0,20$ & 4 \\
\hline $\mathrm{Na}\left(\mathrm{mg} / \mathrm{L}^{-1}\right)$ & 1,35 & $1,42 \pm 0,20$ & 5 \\
\hline $\mathrm{K}\left(\mathrm{mg} / \mathrm{L}^{-1}\right)$ & 0,49 & $0,55 \pm 0,20$ & 12 \\
\hline $\mathrm{F}^{-}\left(\mathrm{mg} / \mathrm{L}^{-1}\right)$ & $0,05^{\mathrm{b}}$ & $0,02^{\mathrm{b}} \pm 0,03$ & $57^{\mathrm{b}}$ \\
\hline $\mathrm{Cl}\left(\mathrm{mg} / \mathrm{L}^{-1}\right)$ & 1,39 & $1,53 \pm 0,08$ & 10 \\
\hline $\mathrm{NO}_{3}^{-}\left(\mathrm{mg} / \mathrm{L}^{-1}\right)$ & 1,52 & $1,45 \pm 0,30$ & 5 \\
\hline $\mathrm{SO}_{4}^{2-}\left(\mathrm{mg} / \mathrm{L}^{-1}\right)$ & 3,40 & $3,56 \pm 0,17$ & 5 \\
\hline $\mathrm{HCO}_{3}^{-}\left(\mathrm{mg} / \mathrm{L}^{-1}\right)$ & 42,30 & $38,20 \pm 0,50$ & 10 \\
\hline
\end{tabular}

Tabela 4.3 - Resultados obtidos para o padrão PERADE.

\begin{tabular}{|c|c|c|c|}
\hline & \multicolumn{3}{|c|}{ PARÂMETROS } \\
\hline & Valor Esperado & 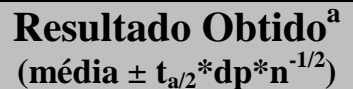 & $\mathrm{CV}^{-\mathrm{c}}(\%)$ \\
\hline $\mathrm{Ca}\left(\mathrm{mg} / \mathrm{L}^{-1}\right)$ & 3,4 & $3,22 \pm 0,25$ & 6 \\
\hline $\operatorname{Mg}\left(\mathrm{mg} / \mathrm{L}^{-1}\right)$ & 0,44 & $0,45 \pm 0,06$ & 1 \\
\hline $\mathrm{Na}\left(\mathrm{mg} / \mathrm{L}^{-1}\right)$ & 1,50 & $1,60 \pm 0,09$ & 5 \\
\hline $\mathrm{K}\left(\mathrm{mg} / \mathrm{L}^{-1}\right)$ & 0,36 & $0,37 \pm 0,06$ & 3 \\
\hline$F^{-}\left(\mathrm{mg} / \mathrm{L}^{-1}\right)$ & $0,04^{\mathrm{b}}$ & $0,04^{\mathrm{b}} \pm 0,01$ & $0^{\mathrm{b}}$ \\
\hline $\mathrm{Cl}\left(\mathrm{mg} / \mathrm{L}^{-1}\right)$ & 0,96 & $0,95 \pm 0,08$ & 1 \\
\hline $\mathrm{NO}_{3}^{-}\left(\mathrm{mg} / \mathrm{L}^{-1}\right)$ & 1,02 & $0,90 \pm 0,05$ & 11 \\
\hline $\mathrm{SO}_{4}^{2-}\left(\mathrm{mg} / \mathrm{L}^{-1}\right)$ & 3,26 & $3,35 \pm 0,09$ & 3 \\
\hline $\mathrm{HCO}_{3}^{-}\left(\mathrm{mg} / \mathrm{L}^{-1}\right)$ & 6,35 & $6,64 \pm 0,02$ & 5 \\
\hline
\end{tabular}


Tabela 4.4 - Controle de qualidade do padrão C - basalto.

\begin{tabular}{|c|c|c|c|}
\hline \multirow[b]{2}{*}{ MAIORES (\%) } & \multicolumn{3}{|c|}{ TIME } \\
\hline & Valor Esperado & $\begin{array}{l}\text { Resultado Obtido } \\
\left(\text { média } \pm t_{a / 2} * d p * n^{-1 / 2}\right)\end{array}$ & $\mathbf{C V}^{\mathbf{b}}(\%)$ \\
\hline $\mathrm{SiO}_{2}$ & 50,00 & 50,00 & 3 \\
\hline $\mathbf{A l}_{2} \mathbf{O}_{3}$ & 12,50 & 12,96 & 9 \\
\hline $\mathrm{Fe}_{2} \mathrm{O}_{3}$ & 15,80 & 14,78 & 6 \\
\hline $\mathrm{CaO}$ & 9,00 & 9,54 & 4 \\
\hline MgO & 5,20 & 5,00 & 3 \\
\hline $\mathrm{TiO}_{2}$ & 4,04 & 4,01 & 2 \\
\hline $\mathrm{Na}_{2} \mathrm{O}$ & 2,66 & 2,43 & 4 \\
\hline $\mathbf{K}_{2} \mathbf{O}$ & 0,75 & 0,64 & 10 \\
\hline $\mathrm{MnO}_{2}$ & 0,20 & 0,20 & 3 \\
\hline PF & - & 0,46 & 9 \\
\hline TOTAL & - & 99,99 & 3 \\
\hline \multirow[b]{2}{*}{ TRAÇOS (ppm) } & \multicolumn{3}{|c|}{ PARÂMETROS } \\
\hline & Valor Esperado & 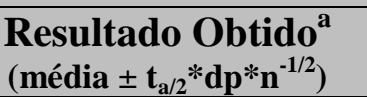 & $\mathbf{C V}^{\mathbf{b}}(\%)$ \\
\hline $\mathbf{N b}$ & 33,00 & 45,01 & 47 \\
\hline $\mathbf{C u}$ & 110,0 & 117,1 & 10 \\
\hline Zn & 93,00 & 128,6 & 7 \\
\hline $\mathbf{Z r}$ & 270,0 & 260,5 & 4 \\
\hline Be & 2,00 & 2,81 & 100 \\
\hline Co & 115,0 & 106,4 & 6 \\
\hline $\mathbf{B a}$ & 410,0 & 389,4 & 3 \\
\hline $\mathrm{Sr}$ & 498,0 & 490,1 & 1 \\
\hline $\mathbf{V}$ & 470,0 & 515,9 & 10 \\
\hline $\mathbf{N i}$ & 50,00 & 60,92 & 43 \\
\hline $\mathrm{Cr}$ & 51,00 & 70,42 & 13 \\
\hline
\end{tabular}


Tabela 4.5 - Resultados estatísticos relevantes e figuras de mérito obtidas pela análise de 5 curvas de calibração independentes lidas em 3 dias diferentes.

\begin{tabular}{|c|c|c|c|c|c|}
\hline Equipamento & Parâmetro & $\mathbf{L D}^{\mathrm{a}}\left(\mathrm{mg} \mathrm{L}^{-1}\right)$ & $\mathbf{L Q}^{\mathrm{b}}\left(\mathrm{mg} \mathrm{L}^{-1}\right)$ & $\operatorname{FLT}^{\mathrm{c}}\left(\mathrm{mg} \mathrm{L}^{-1}\right)$ & $\mathbf{R} 2^{\mathrm{d}}$ \\
\hline \multirow[b]{2}{*}{$\mathbf{A A}$} & $\mathrm{Na}$ & 0,02 & 0,09 & $0,5-5$ & 0,99 \\
\hline & $\mathbf{K}$ & 0,03 & 0,09 & $0,5-5$ & 0,99 \\
\hline \multirow{5}{*}{ IC } & $\mathbf{F}^{-}$ & 0,01 & 0,08 & $0,2-1$ & 0,99 \\
\hline & $\mathrm{Cl}^{-}$ & 0,05 & 0,18 & $0,5-10$ & 0,99 \\
\hline & $\mathrm{NO}_{3}^{-}$ & 0,02 & 0,08 & $0,2-10$ & 0,99 \\
\hline & $\mathrm{PO}_{4}{ }^{3-}$ & 0,01 & 0,02 & $0,2-5$ & 0,98 \\
\hline & $\mathrm{SO}_{4}{ }^{2-}$ & 0,05 & 0,20 & $0,7-15$ & 0,99 \\
\hline \multirow{15}{*}{ ICP/OES } & $\mathbf{S i}$ & 0,011 & 0,10 & $1,0-10$ & 0,99 \\
\hline & Al & 0,027 & 0,20 & $1,0-30$ & 0,98 \\
\hline & $\mathbf{F e}$ & 0,022 & 0,20 & $1,0-20$ & 0,99 \\
\hline & $\mathrm{Ca}$ & 0,066 & 0,60 & $0,8-40$ & 0,97 \\
\hline & Mg & 0,017 & 0,10 & $2,0-18$ & 0,99 \\
\hline & $\mathbf{T i}$ & 0,03 & 0,40 & $1,0-10$ & 0,99 \\
\hline & $\mathrm{Cu}$ & 0,20 & 2,00 & $2,0-4$ & 0,98 \\
\hline & $\mathbf{Z n}$ & 0,04 & 0,40 & $0,8-4$ & 0,99 \\
\hline & Co & 0,18 & 1,18 & $1,3-4$ & 0,99 \\
\hline & Ba & 0,30 & 3,00 & $4,0-20$ & 0,98 \\
\hline & $\mathbf{S r}$ & 0,30 & 3,00 & $3,5-20$ & 0,98 \\
\hline & Mn & 0,01 & 0,10 & $0,7-20$ & 0,99 \\
\hline & $\mathbf{V}$ & 0,20 & 2,00 & $2,0-20$ & 0,99 \\
\hline & $\mathbf{N i}$ & 0,15 & 1,50 & $1,7-20$ & 0,99 \\
\hline & $\mathrm{Cr}$ & 0,20 & 2,00 & $2,7-20$ & 0,99 \\
\hline
\end{tabular}

${ }^{a}$ Limite de detecção, calculado pelo aparelho em relação ao BEC ou ruído do aparelho; ${ }^{b}$ Limite de quantificação: para AA e IC foi calculado pela curva de calibração: $10 \mathrm{x} \mathrm{S}_{\mathrm{y} / \mathrm{x}} \mathrm{x} \mathrm{b}^{-1}\left(\mathrm{~S}_{\mathrm{y} / \mathrm{x}}=\right.$ desvio padrão da curva de resíduos para ao ajuste linear e $\mathrm{b}=$ coeficiente angular da curva de resíduos) ou; para ICP/OES foi igual a 10x o valor do LD; ${ }^{\mathrm{c}}$ Faixa linear de trabalho obtida pelo teste de homocedasticidade; ${ }^{\mathrm{d}}$ Coeficiente de correlação da curva de calibração.

\subsection{Tratamento Estatístico}

Os bancos de dados, tabelas, gráficos e cálculos estatísticos foram preparados com o auxílio do Programa Excel 2007, da Microsoft Corporation e o Programa SPSS 18 utilizado para o agrupamento dos principais elementos evidenciados. Para a caracterização hidroquímica foi utilizado o Diagrama de Piper, que reconhece o comportamento químico e classificam os tipos de água, o programa utilizado para este fim foi QUALIGRAF (FUNCEME). 


\subsubsection{Análise de Componentes Principais}

De acordo com Varella (2008) a análise de componentes principais é uma ferramenta estatística multivariada que transforma um conjunto de variáveis originais em outros conjuntos de variáveis de mesma dimensão denominadas de componentes principais. Os componentes principais são combinações lineares de todas as variáveis originais, independentes entre si e estimados com o propósito de reter, em ordem de estimação, o máximo de informação, em termos da variação total contida nos dados. $\mathrm{O}$ componente principal é importante porque avalia a proporção de variância total explicada pelo componente. Assim a variância associada à primeira componente será maior que aquela associada à segunda, e assim progressivamente. Os valores das componentes são expressos pelos escores que evidenciam a influencia da componente sobre a amostra de cada ponto (VARELLA, 2008).

A análise de componentes principais consiste essencialmente em reescrever as coordenadas das amostras em outro sistema de eixo mais conveniente para a análise dos dados. As variáveis originais geram por combinações lineares, $\mathrm{n}$ - componentes principais e os principais objetivos em utilizá-lo consistem na redução da dimensionalidade dos dados, obtenção de combinações interpretáveis e descrição e entendimento da estrutura de correlação (NETO et al.,1997).

Neste estudo, a ACP foi usada com objetivos de reduzir a extensão do conjunto dos dados geoquímicos e identificar os parâmetros mais significativos (variáveis com características semelhantes, o peso associado a cada uma delas) sem que as informações relevantes dos dados originais fossem perdidas. Foi utilizada a rotação varimax para calcular os coeficientes de correlação que resulta na maximização de variação dos pesos (KAISER, 1958). A partir dos dados obtidos, buscou-se ferramentas que possibilitaram gerar dados de avaliação ambiental, para isso foi escolhido procedimento estatístico SPSS 18.

Como os aparelhos espectrômetros de emissão atômica e de massa costumam ter limitações na detecção de determinados elementos, estes exibem valores nulos, o que significa que a concentração observada encontra-se abaixo da capacidade de percepção do aparelho. Para análise multivariada, os resultados mostraram que a substituição por LD/2 obteve melhor aproveitamento quando comparado com a substituição por zero.

Assim, só há desempenho quando a substituição dos valores não excederem $25 \%$ dos dados (FARNHAM et al., 2002). Sendo assim, os valores < LD foram substituídos por LD/2 e 
os parâmetros que constituíam valores acima de $75 \%$ dos valores $<\mathrm{LD}$ foram deixados de fora da compilação dos dados por APC (CHEN et al.,2007).

\subsubsection{Análise de Grupos (Cluster Analysis)}

A análise de agrupamento é uma variedade de técnicas de análise multivariada que tem como objetivo reunir as observações similares na mesma classe e as dissimilaridades em classes diferentes. O princípio da análise de agrupamento consiste em encontrar um melhor modo de descrever seus padrões de similaridade mútuos, evidenciando aspectos marcantes da amostra, por meio de uma dada amostra de $\mathbf{n}$, em que cada um deles medidos por $\mathbf{p}$ variáveis, a partir disso identificar um melhor esquema que agrupe as amostras (GIMENES et al.,1998).

Em termos gerais a classificação é dada em localizar e organizar amostras similares entre si em algum sentido pelas variáveis consideradas. Essa classe de amostras denomina-se agrupamentos. A suposição fundamental de sua interpretação é que quanto menor a distância dos pontos, maior a semelhança entre as amostras. De tal modo que o aspecto descritivo seja como resultado final um gráfico de esquemas hierárquico denominado dendograma.

\subsection{3 Índice de geoacumulação}

Para a avaliação de intensidade de contaminação do sedimento, foi empregada a análise de acumulação de metais, que foram associados aos valores background, podendo assim obter índices de geoacumulação mais confiáveis (MULHOLLAND, 2009). Este índice consiste em sete classes distintas que variam de 0 a 6 e estão relacionados com o grau crescente de contaminação (Tabela 4.6). O valor mais alto corresponde a um enriquecimento de aproximadamente 100 vezes em relação ao nível de background, o qual é calculado de acordo com fórmula do Igeo: $\log _{2}\left(\mathrm{C}_{\mathrm{N}} / 1,5 \mathrm{C}_{\mathrm{B}}\right)$.

$\mathrm{C}_{\mathrm{N}=}$ Concentração do elemento a ser classificado;

$\mathrm{C}_{\mathrm{B}=}$ Concentração média de background;

1,5= é o fator de correção para possíveis variações no background; 
Tabela 4.6 - Classes do Índice de geo-acumulação

\begin{tabular}{lll}
\hline Acumulação & Classe & Igeo \\
\hline Extrema & 6 & Igeo $>5$ \\
Forte a Extrema & 5 & $4<$ Igeo $<5$ \\
Forte & 4 & $3<$ Igeo $<4$ \\
Moderada a Forte & 3 & $2<$ Igeo $<3$ \\
Moderada & 2 & $1<$ Igeo $<2$ \\
Ausente à Moderada & 1 & $0<$ Igeo $<1$ \\
Ausente & 0 & Igeo $<0$ \\
\hline
\end{tabular}




\subsection{Análise das amostras de água}

\subsubsection{Potencial Hidrogeniônico (pH), Alcalinidade e $\mathrm{CO}_{2}$}

O córrego Campo Alegre apresentou valores de pH variando de 5,02 a 6,60 na estação seca e 5,63 a 6,63 na estação chuvosa, considerados levemente ácidos ( Figura 5.1).

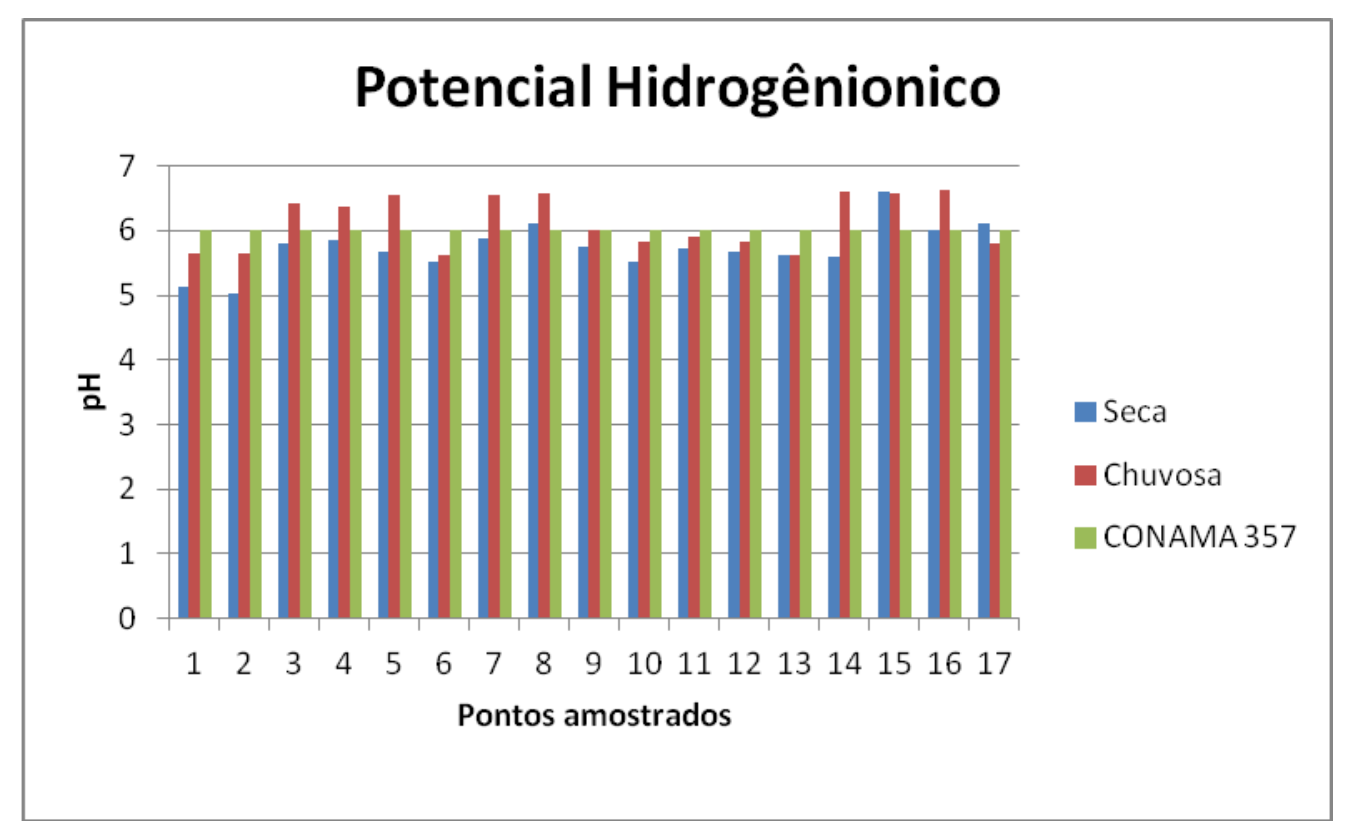

Figura 5.1- Concentração de pH no córrego Campo Alegre durante a estação seca e chuvosa comparada com a Resolução CONAMA 357.

Os resultados obtidos nas coletas realizadas encontram-se abaixo dos valores estabelecidos pela Resolução CONAMA 357/05 (6,0 a 9,0 para águas doces), contudo os mesmos não provocam modificações significativas no ambiente aquático. No período seco houve diminuição do $\mathrm{pH}$ associado à dissolução de substâncias húmicas e fúlvicas presentes no sedimento aluvionar gerados pela decomposição da matéria orgânica . Von Sperling ressalta que, as reações bioquímicas do metabolismo das raízes das plantas contribuem para a alta concentração de ácidos orgânicos armazenados e concentrados no período seco.

[...] a oxidação de matéria orgânica reduz o $\mathrm{pH}$, assim valores baixos de $\mathrm{pH}$ retrata elevadas concentrações de ácidos orgânicos dissolvidos de origem alóctone e autóctone, [...] para haver decomposição de materiais ocorre a produção de ácidos como o ácido húmico, dissolução de rochas e absorção de gases da atmosfera (VON SPERLING, 1996). 
Durante o período chuvoso, as elevações de $\mathrm{pH}$ podem ter origem natural da dissolução de rochas provenientes da formação geológica de solos lixiviados e pobres em bases, característicos da pedologia de Campo Alegre, absorção de gases da atmosfera e oxidação da matéria orgânica. Ao observar a descrição ocorrida no ponto 6, é identificado uma queda no $\mathrm{pH}$ que variou entre 5,52 a 5,63, provavelmente devido a interferência antrópica pontual (lixão) ocasionando aumento da matéria orgânica decomposta. Substâncias ácidas em grandes quantidades adicionadas à água, ao alterarem o pH, são neutralizadas por íons carbonatados que agem como uma espécie de tampão no sistema hídrico chamado de alcalinidade. $\mathrm{O}$ Córrego Campo Alegre apresentou alcalinidades mais elevadas no período chuvoso $(3,89$ a $14,88 \mathrm{mg} / \mathrm{L})$ do que em períodos $\operatorname{secos}(2,5$ a $10,5 \mathrm{mg} / \mathrm{L})$ devido ao acúmulo de materiais ácidos e orgânicos lançados no meio aquoso pelo escoamento superficial (Figura 5.2).

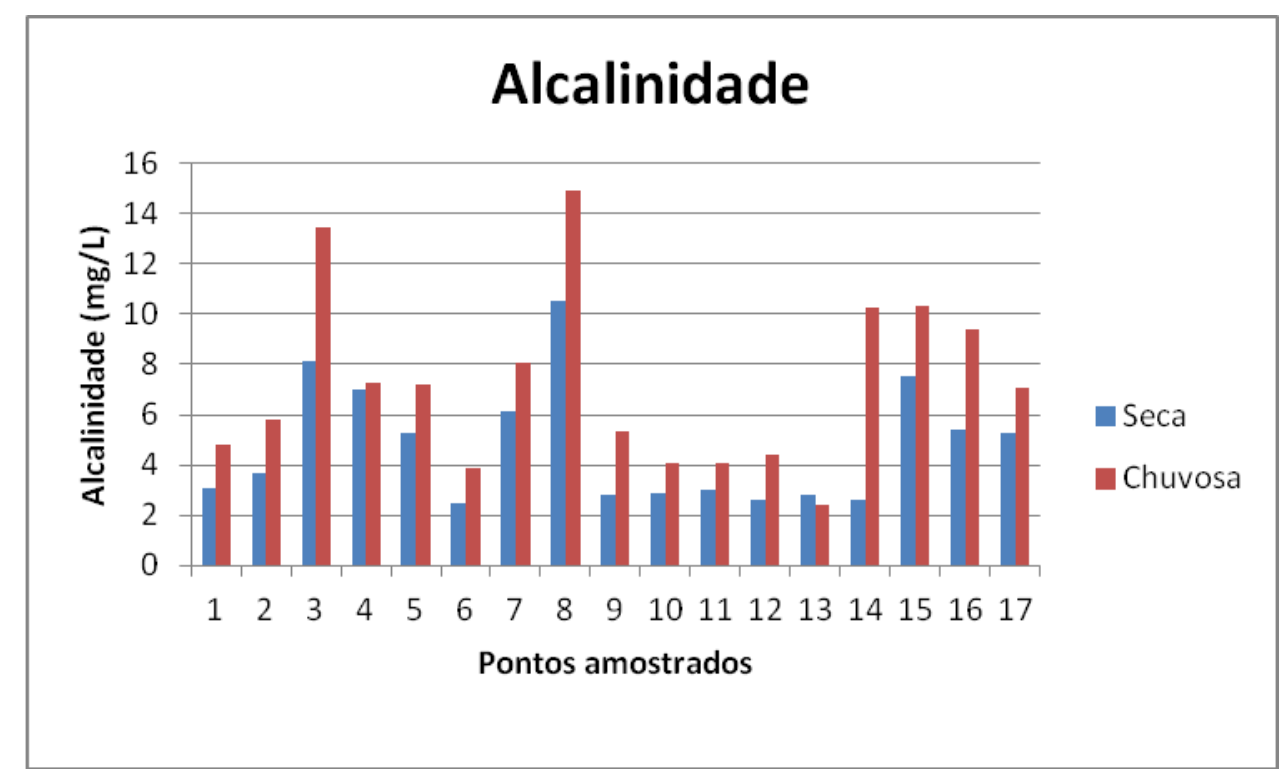

Figura 5.2 - Concentração da alcalinidade total nas águas durante os períodos da seca e da chuva, de montante para jusante do córrego Campo Alegre.

Os maiores valores de alcalinidade se encontram nos pontos P3 e P8 localizados no centro da cidade. Os pontos situados no perímetro urbano $(3,4,5,6,7$ e 8$)$ retratam o efeito das ações antrópicas e a diferença de estações (seca e chuvosa) na alteração da qualidade da água do córrego. Águas receptoras de efluentes e esgotos domésticos costumam apresentar alta alcalinidade devido aos compostos silicatados e fosfatados, indicando contaminação por efluentes industriais como os ocorridos nos pontos 14, 15 e 16. Outro parâmetro diretamente relacionado ao $\mathrm{pH}$ e aos carbonatos é o dióxido de carbono $\left(\mathrm{CO}_{2}\right)$ (PÁDUA, 2014). Esse 
parâmetro no córrego Campo Alegre variou de 2,82 mg/L para o período chuvoso e 6,33 para o período seco. $\mathrm{O}$ aumento do $\mathrm{CO}_{2}$ no período seco, proporcionou aos pontos amostrados na pesquisa valores menores de $\mathrm{pH}$. Na estação chuvosa, o ligeiro aumento de $\mathrm{CO}_{2}$ dissolvido na água precipitada capturado da atmosfera, ocasionou maior solubilização de carbonatos. Vale ressaltar que os parâmetros de dióxido de carbono e a alcalinidade não possuem referência dentro da resolução 357/05 do CONAMA.

\subsubsection{Condutividade Elétrica, Total de Sólidos Dissolvidos, $\mathrm{Ca}, \mathrm{Mg}, \mathrm{Na}, \mathrm{K}, \mathrm{Cl}^{-} \mathrm{e} \mathrm{O}_{3}{ }^{-}$}

A condutividade elétrica da água do córrego Campo Alegre variou de 5,20 a 56,40 entre as duas estações analisadas. De acordo com a CETESB (2013), níveis superiores a $100 \mu \mathrm{S}$ $\mathrm{cm}^{-1}$ indicam ambientes impactados, assim pode-se considerar que, na área não há grandes alterações no recurso hídrico pelas atividades humanas desenvolvidas, conforme indica a Figura 5.3. Porém, mesmo que os resultados obtidos reflitam valores abaixo de $100 \mu \mathrm{S} \mathrm{cm}^{-1}$, não se pode afirmar que o corpo hídrico esteja isento de contaminantes. Alguns locais amostrados, pontos 14, 15 e 16 encontram-se impactados por receberem efluentes da Estação de Tratamento de água enriquecidos de compostos químicos e pontos 3 e 8 , descargas de esgotos, resíduos domésticos e industriais. Todos esses fatores contribuem para a modificação da composição da água ao serem incorporados aos sistemas lóticos, favorecendo para o aumento da condutividade.

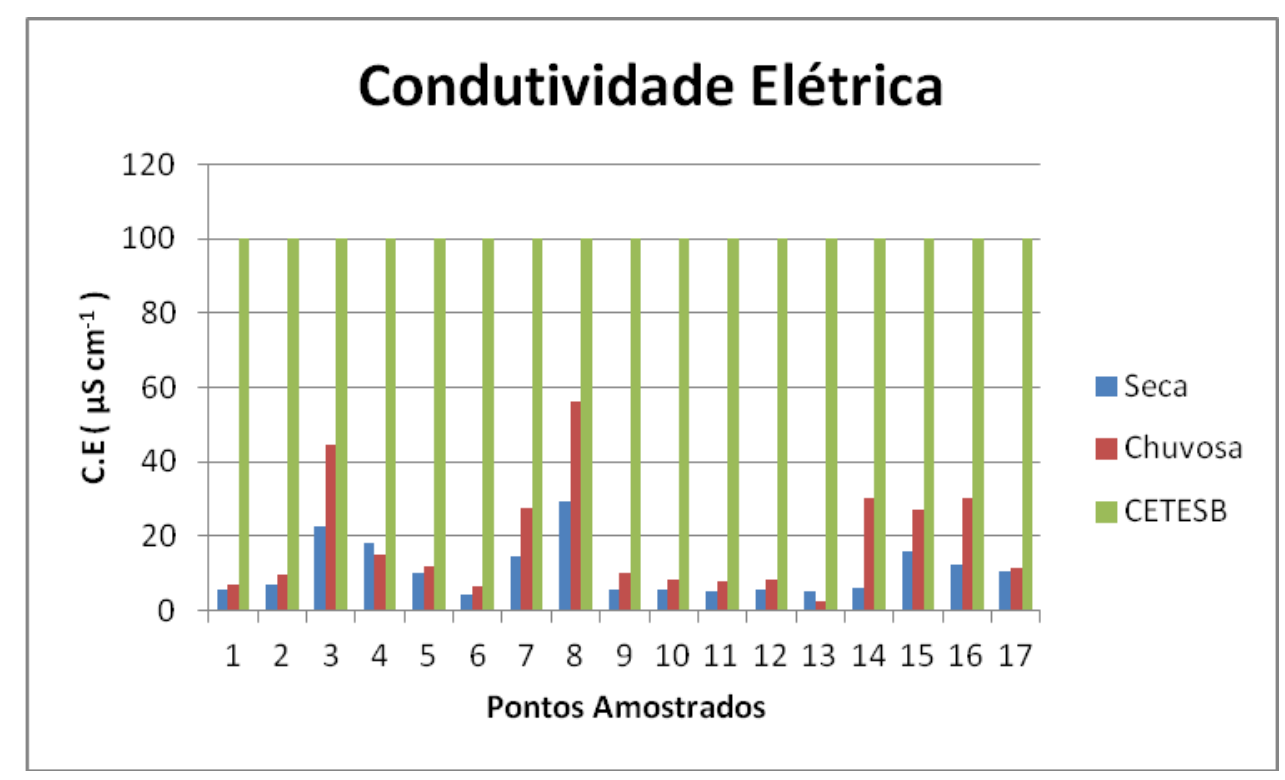

Figura 5.3 - Valores de condutividade elétrica $(\mu \mathrm{S} / \mathrm{cm})$ das águas do córrego Campo Alegre nas estações chuvosa e seca. 
Os parâmetros condutividade elétrica e total de sólidos dissolvidos tendem a aumentar no período chuvoso, uma vez que as águas de escoamento superficial carreiam grande volume de substâncias orgânicas e materiais em suspensão por simples ação mecânica ou pela dissolução de materiais solúveis (exemplo, fragmentos de rochas carbonáticas utilizados como agregados na massa asfáltica, PERES,et al., 2009). No período seco, como não há escoamento superficial, a condutividade elétrica relaciona-se apenas aos íons disponibilizados a partir dos solos, que no caso da bacia em estudo é baixa pois, os xistos presentes na região são subaflorantes pouco solúveis.

Também nos pontos 3 e 8 se encontram os maiores valores de $\mathrm{Ca}, \mathrm{Mg}, \mathrm{Na}, \mathrm{Ka}, \mathrm{Cl}^{-}$e $\mathrm{NO}_{3}{ }^{-}$(Tabela 5.1). Esses elementos são disponibilizados no sistema hídrico por escoamentos superficiais em terrenos agrícolas ou rejeitos industriais e esgotos. Grandes quantidades, principalmente de $\mathrm{Cl}^{-}$e $\mathrm{NO}_{3}{ }^{-}$em águas superficiais, indicam condições sanitárias inadequadas $\mathrm{o} \mathrm{NO}_{3}{ }^{-}$ainda favorece a proliferação de microrganismos.

Tabela 5.1 - Resultados dos elementos químicos na água do córrego Campo Alegre.

\begin{tabular}{|c|c|c|c|c|c|c|c|c|c|c|c|c|}
\hline & \multicolumn{2}{|c|}{$\mathbf{C a}$} & \multicolumn{2}{|c|}{ Mg } & \multicolumn{2}{|c|}{$\mathrm{Na}$} & \multicolumn{2}{|c|}{$\mathbf{K}$} & \multicolumn{2}{|c|}{$\mathrm{Cl}^{-}$} & \multicolumn{2}{|c|}{$\mathrm{NO}_{3}{ }^{-}$} \\
\hline & Seca & Chuva & Seca & $\begin{array}{l}\text { Chu } \\
\text { va }\end{array}$ & Seca & Chuva & Seca & Chuva & Seca & Chuva & Seca & Chuva \\
\hline P1 & 0,6 & 0,90 & 0,2 & $<\mathrm{LQ}$ & 0,2 & 0,4 & 0,1 & 0,12 & 0,3 & 0,23 & $<\mathrm{LQ}$ & 0,35 \\
\hline P2 & 0,5 & 1,30 & 0,2 & $<\mathrm{LQ}$ & 0,3 & 0,3 & 0,1 & 0,10 & 0,4 & 0,39 & $<\mathrm{LQ}$ & 0,33 \\
\hline P3 & 1,9 & 6,18 & 0,2 & $\mathbf{0 , 3 5}$ & 2,0 & 2,1 & 0,3 & 0,40 & 1,6 & 2,26 & 2,0 & 3,06 \\
\hline P4 & 1,7 & 1,16 & 0,2 & 0,24 & 1,2 & 1,3 & 0,7 & 0,80 & 1,5 & 0,39 & 0,6 & 0,56 \\
\hline P5 & 0,9 & 1,29 & 0,2 & 0,22 & 0,4 & 0,5 & 0,2 & 0,25 & 0,6 & 0,25 & $<\mathrm{LQ}$ & 0,34 \\
\hline P6 & 0,4 & 0,45 & $<\mathrm{LQ}$ & 0,13 & 0,3 & 0,6 & 0,1 & 0,10 & 0,3 & 0,38 & $<\mathrm{LQ}$ & 0,37 \\
\hline P7 & 1,0 & 1,76 & 0,2 & 0,29 & 1,4 & 3,5 & 0,3 & 0,30 & 1,2 & 1,15 & 0,9 & 2,68 \\
\hline P8 & 1,8 & 8,38 & 0,4 & 0,44 & 3,4 & 2,0 & 0,5 & $\mathbf{0 , 5 5}$ & 2,5 & 2,70 & 2,70 & 4,24 \\
\hline P9 & 0,4 & 1,05 & 0,2 & 0,21 & 0,4 & 0,6 & 0,1 & 0,10 & 0,3 & 0,51 & 0,4 & 0,55 \\
\hline P10 & 0,3 & 0,95 & $<\mathrm{LQ}$ & 0,14 & 0,4 & 0,5 & 0,1 & 0,10 & 0,4 & 0,41 & $<\mathrm{LQ}$ & 0,38 \\
\hline P11 & 0,4 & 0,70 & $<\mathrm{LQ}$ & 0,15 & 0,4 & 0,5 & 0,1 & 0,08 & 0,4 & 0,41 & $<\mathrm{LQ}$ & 0,31 \\
\hline P12 & 0,3 & 0,81 & 0,2 & 0,15 & 0,4 & 0,5 & $<\mathrm{LQ}$ & 0,06 & 0,4 & 0,35 & $<\mathrm{LQ}$ & 0,32 \\
\hline P13 & 0,4 & 0,13 & $<\mathrm{LQ}$ & 0,05 & 0,4 & 0,4 & 0,1 & 0,08 & 0,4 & $<\mathrm{LQ}$ & $<\mathrm{LQ}$ & 0,30 \\
\hline P14 & 0,5 & 4,75 & 0,2 & 0,15 & 0,4 & 1,1 & 0,1 & 0,08 & 0,4 & $<\mathrm{LQ}$ & $<\mathrm{LQ}$ & 0,36 \\
\hline P15 & 2,5 & 4,29 & 0,2 & 0,16 & 0,5 & 1,0 & 0,1 & 0,08 & 0,4 & 0,43 & $<\mathrm{LQ}$ & 0,33 \\
\hline P16 & 1,9 & 5,02 & 0,2 & 0,13 & 0,5 & 0,8 & 0,1 & 0,10 & 0,7 & 1,12 & 0,2 & 0,34 \\
\hline P17 & 1,7 & 1,72 & 0,1 & 0,29 & $<\mathrm{LD}$ & $<\mathrm{LD}$ & $<\mathrm{LD}$ & $<\mathrm{LQ}$ & 0,9 & 1,03 & $<\mathrm{LD}$ & 0,86 \\
\hline
\end{tabular}

LQ: Limite de Quantificação, LD: Limite de detecção.

\subsubsection{Cátions e Ânions}

As análises realizadas para os cátions e ânions nas duas estações (seca e chuvosa) mostraram que as maiores variabilidades ocorreram com $\mathrm{HCO}_{3}^{-}, \mathrm{Ca}^{+2} \mathrm{e} \mathrm{Na}^{+}$, dos quais obtiveram os maiores valores em suas concentrações. Em seguida se apresentam o $\mathrm{Cl}^{-}, \mathrm{Si}^{+} \mathrm{K}^{+}$

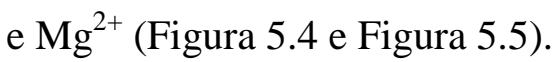




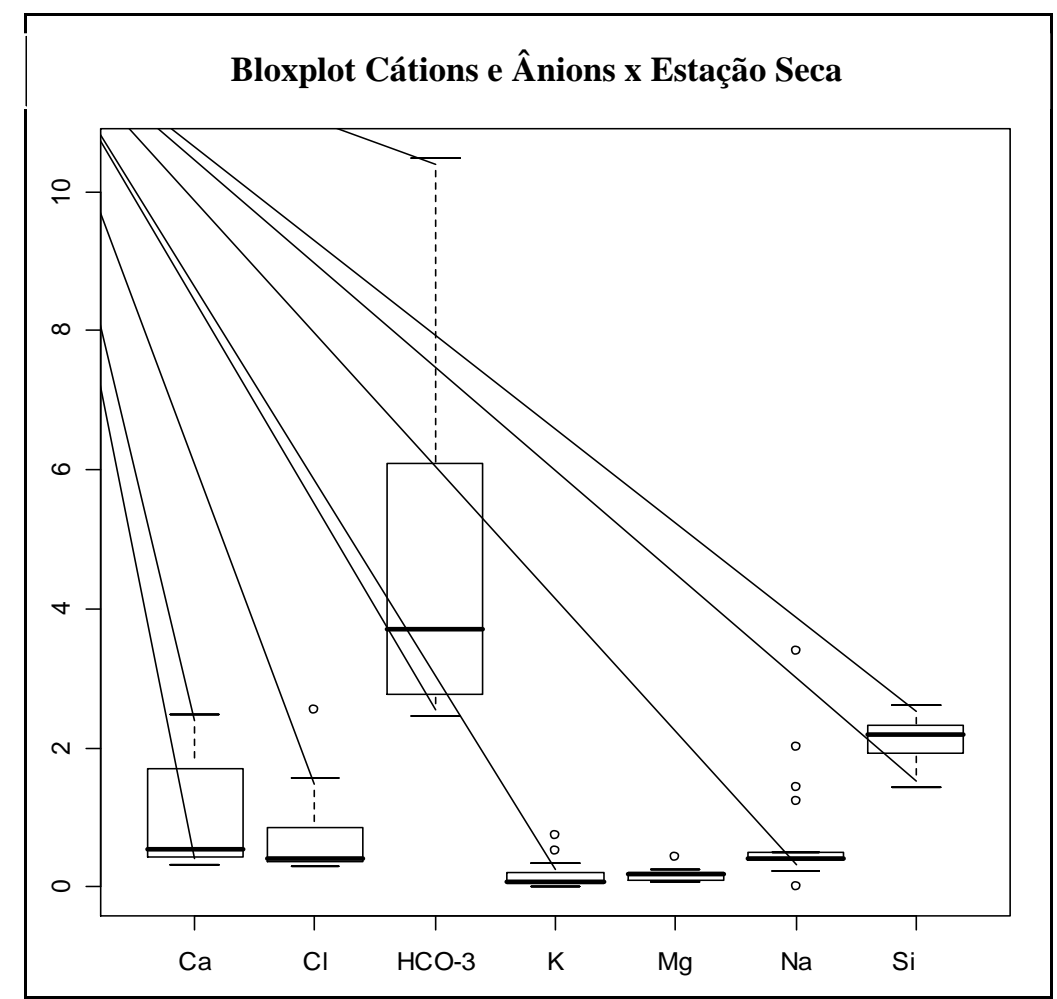

Figura 5.4 - Bloxplot dos cátions e ânions para todos os pontos na estação seca.

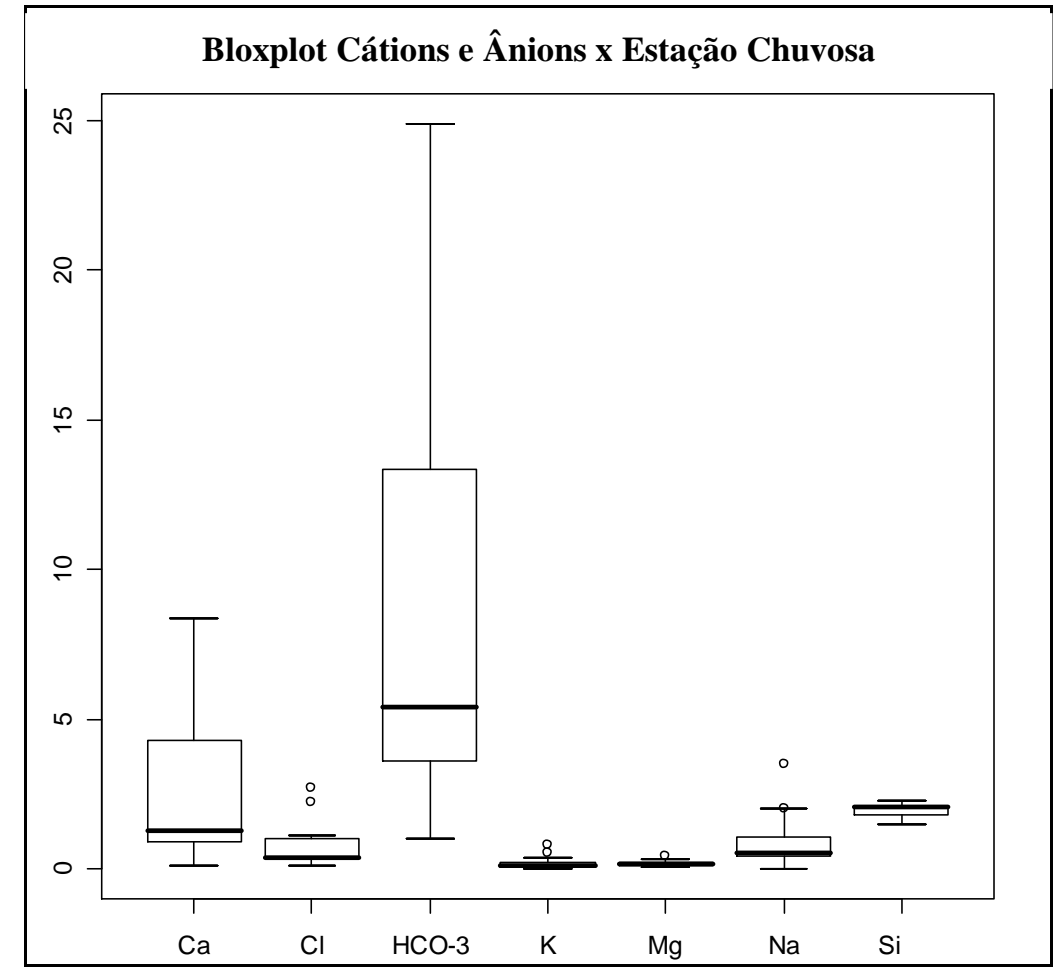

Figura 5.5 - Bloxplot dos cátions e ânions para todos os pontos na estação chuvosa. 
$\mathrm{O}$ bicarbonato $\left(\mathrm{HCO}_{3}^{-}\right)$e o cálcio $\left(\mathrm{Ca}^{2+}\right)$ foram os ânions com maior concentração em ambas as estações se destacando na estação chuvosa e contribuindo para o aumento da condutividade elétrica devido à concentração de íons dissolvidos. De acordo com Esteves (1998), os íons $\mathrm{Ca}^{2+}, \mathrm{Na}^{+}, \mathrm{Mg}^{+2}$ e $\mathrm{K}^{+}$são responsáveis pela elevação nos valores da condutividade.

O Sódio $\left(\mathrm{Na}^{+}\right)$foi o segundo cátion com maior concentração na estação chuvosa, variando de $1 \mathrm{mg} / \mathrm{L}$ a $10 \mathrm{mg} / \mathrm{L}$. Segundo a CETESB (2009), águas superficiais, incluindo aquelas que recebem efluentes, apresentam valores abaixo de $50 \mathrm{mg} / \mathrm{L}$. Os valores encontrados nas análises para esse cátion se enquadram dentro dos limites permitidos para potabilidade e as variações podem ser provenientes de sais utilizados na pecuária, excretados através da urina, bem como descargas de efluentes. Sabe-se também que as concentrações de $\mathrm{Na}^{+}$dependem das condições geológicas do local, porém as análises da mineralogia dos solos não mostram nenhum mineral em que este composto ocorra de forma expressiva.

$\mathrm{O} \mathrm{Mg}^{+2}$ é encontrado em águas naturais de $\mathrm{pH}$ alto em torno de $8 \mathrm{mg} / \mathrm{L}$ com ausência de oxigênio (MORUZII, 2012). Pode ser advindo de atividade agrícola, doméstica e indústrias químicas. Os dados desse trabalho mostram que em nenhum ponto os valores obtidos podem ser considerados anômalos. Durante as análises realizadas constatou-se baixa concentração de magnésio nas águas superficiais analisadas, o que foi detectado pode ser proveniente das atividades agrícolas realizadas na região, pois estas se encontram próximas aos pontos de coleta. A calagem dos solos que correspondem à adição de dolomita $\left(\mathrm{Ca} \cdot \mathrm{Mg}\left(\mathrm{CO}_{3}\right)_{2}\right)$, é responsável pelo conteúdo deste cátion nas águas.

O Silício ( $\mathrm{Si}$ ) encontra-se em quantidade maior na estação seca por ser oriundo do quartzo, mineral presente na composição geológica do solo. Já no período de chuva ele apresenta valores menores por ser considerado um mineral insolúvel se agregando aos sedimentos de fundo. Nos processos geológicos, o estado de equilíbrio-desequilíbrio do silício no sistema água-rocha-matéria orgânica direciona a formação diversificada dos tipos geoquímicos, hidroquímicos e de minerais secundários, depósitos de minérios e de intemperismo (LAZZERINI et al., 2014).

Os valores de cloreto $\left(\mathrm{Cl}^{-}\right)$estabelecidos pela Resolução CONAMA 357/ 2005 pode chegar a $250 \mathrm{mg} / \mathrm{L}$. Todos os valores encontrados para esse ânion na área de pesquisa estão conforme o estabelecido por essa resolução, entretanto sua presença em baixos teores no Córrego Campo Alegre pode associar-se à utilização de produtos a base de cloro no 
tratamento de água. No período seco, a correlação entre o $\mathrm{Na}^{+}$e o $\mathrm{Cl}^{-}$é positiva, ocorrendo de forma linear, já no período chuvoso ocorre de modo disperso. $\mathrm{O}^{-}$foi o único ânion detectável que manteve sua concentração constante nas duas estações.

Os ânions $\mathrm{F}^{-}, \mathrm{PO}^{3-}, \mathrm{SO}^{2-}$ e os cátions $\mathrm{Fe}^{2+}, \mathrm{Al}^{3+}$ (ficaram abaixo do limite de quantificação), enquanto que $\mathrm{o} \mathrm{NO}_{3}{ }^{-}$somente foi detectado em alguns pontos e de forma mais evidente na estação chuvosa. Os elementos Ti, La, V, Ni, Cu, Cr, Ba, Co, Ba. Zn, Mo e Cd encontraram-se abaixo do limite de detecção para a maioria dos pontos.

Avaliando a matriz scatterplots dos parâmetros de amostras de água do Córrego Campo Alegre nas estações (seca e chuvosa) (Figura 5.6 e 5.7) verificou-se comportamentos comuns entre as duas estações nas quais o $\mathrm{Cl}, \mathrm{Na}$ e $\mathrm{HCO}_{3}{ }^{-}$apresentaram as maiores correlações. Para uma correlação significativa considerou-se os valores acima de $70 \%$.

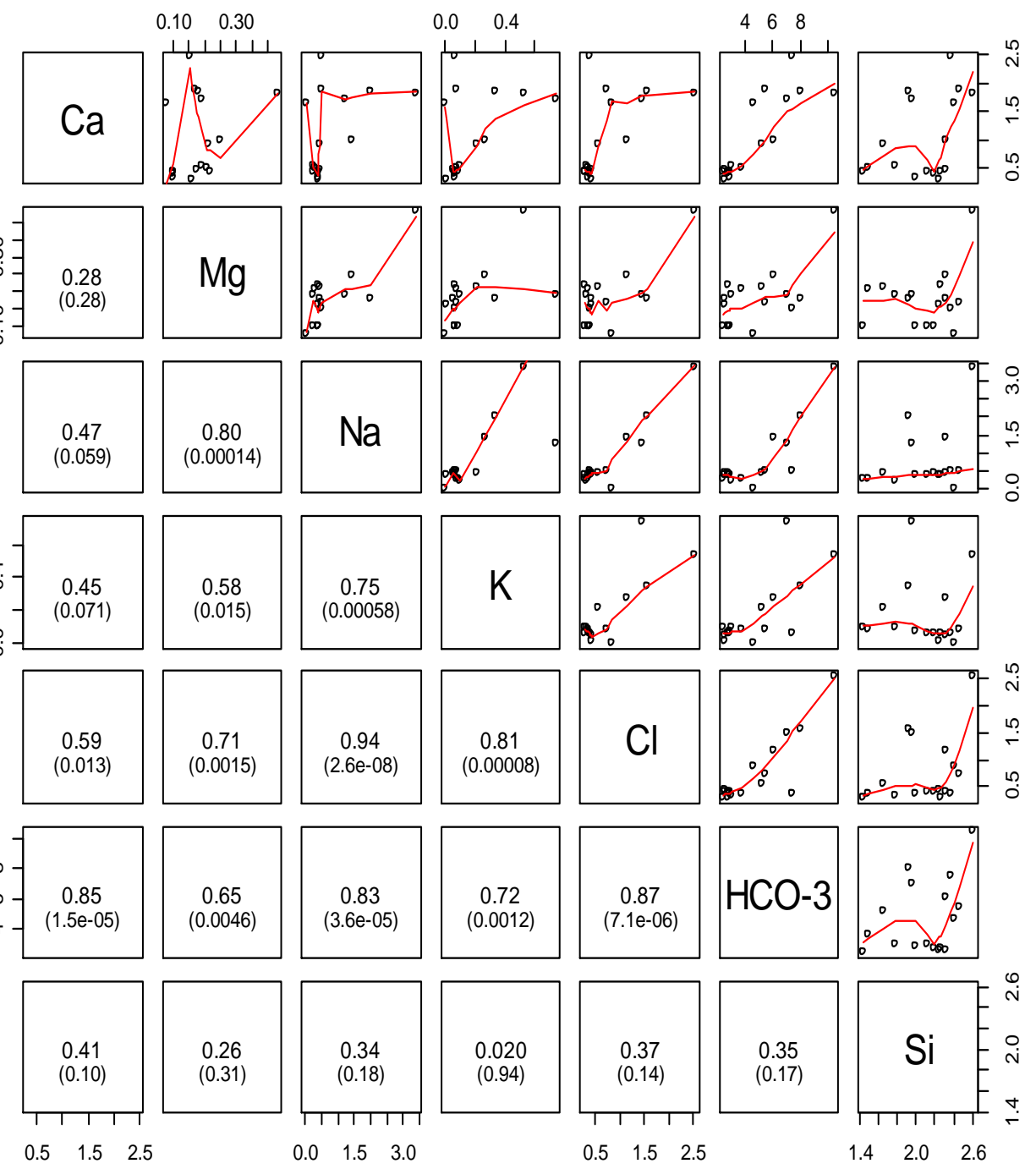

Figura 5.6 - Matriz Scatterplots entre os parâmetros em amostras de água do Córrego Campo Alegre na estação seca. 


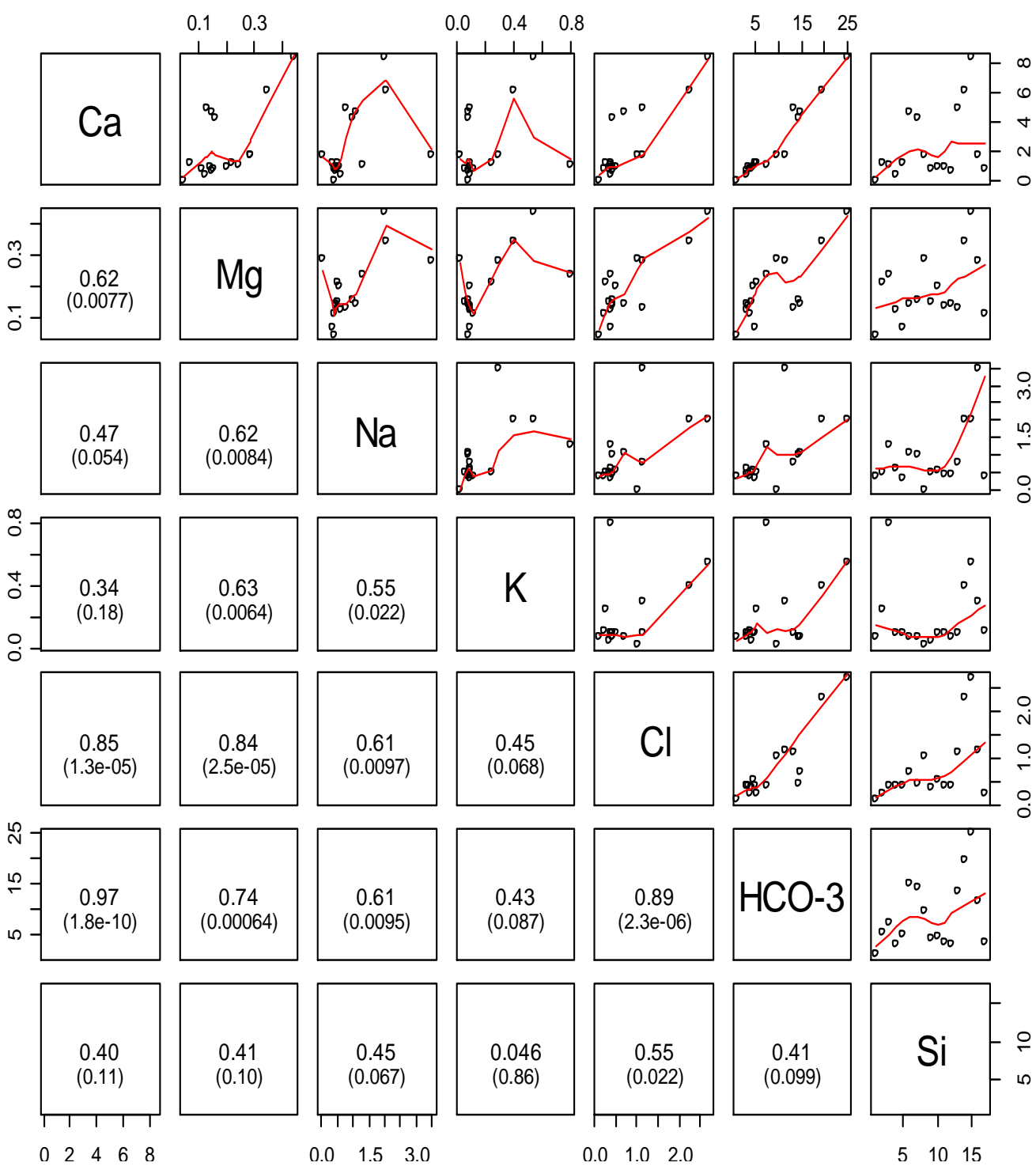

Figura 5.7 - Matriz Scatterplots entre os parâmetros em amostras de água do Córrego Campo Alegre na estação chuvosa.

$\mathrm{Na}$ estação seca, a maior parte dos elementos se correlacionou. O Ca e o Si tiveram baixa correlação com todos os elementos. O cloreto e o sódio apresentaram maior correlação chegando a 94\%, essa correlação é interpretada como compostos originados de resíduos domésticos devido ao uso abundante do $\mathrm{NaCl}^{-}$usado na alimentação humana e utilização do cloreto no tratamento de água para fins de abastecimento (FELTRE, 2004). O cloreto e o potássio também apresentaram forte correlação entre si $(81 \%)$, sendo associada ao uso de fertilizante solúvel que fornece potássio ao solo aumentando sua produtividade. Este fertilizante é principalmente aplicado na forma de cloreto e nitrato de potássio apresentando maior solubilidade (COELHO, 1994). 
O $\mathrm{Na}$ e o $\mathrm{Mg}$ apresentaram correlação de $80 \%$. Esta forte correlação é interpretada como proveniente do uso de defensivos agrícolas. O sódio em concentrações altas na água pode ser trocado pelo magnésio e cálcio adsorvidos nas argilas causando dispersão das partículas e formando estruturas granulares nos solos cultivados (CORDEIRO, 2001). O Na e o K têm correlação de $75 \%$. O potássio é utilizado na fertilização dos solos para agricultura, uma vez que este é um dos elementos mais deficitários em solos brasileiros. O sódio possui similaridade geoquímica com o potássio, devido a este fato pode ocorrer substituição entre estes íons ampliando a produção das culturas (ROMERO, 2008). A correlação entre cloreto e magnésio de $71 \%$ pode ser atribuída a um tipo de fertilizante solúvel comumente utilizado como fonte de magnésio $\left(\mathrm{MgCl}_{2}\right)$.

O bicarbonato teve boa correlação. Correlaciona-se $83 \%$ com o Na, $72 \%$ com o K e $87 \%$ com o $\mathrm{Cl}$. Essas correlações significam que o ânion $\mathrm{HCO}_{3}^{-}$indicam que essas concentrações podem ser decorrentes das precárias condições de infra-estrutura de saneamento básico dos aglomerados urbanos e de atividades agropecuárias.. As altas correlações registradas entre sódio, cálcio, potássio e o bicarbonato pode ser explicadas também, pela presença calcixistos, calcifilitos que são constituídos da geologia local que se relaciona com o processo natural de intemperismo. Devido as águas ácidas em decorrência do $\mathrm{CO}_{2}$ dissolvido em contato com rochas carbonatadas, principalmente calcário, dissolve o carbonato formando bicarbonato.

O Silício na estação seca não se correlacionou com nenhum dos elementos, possivelmente por ser um elemento insolúvel, e sua fonte é derivada de fonte natural pela mineralogia possuir minerais como quartzo, caolinita e ilita que possuem silício em sua composição.

$\mathrm{Na}$ estação chuvosa, a maioria dos elementos não se correlaciona entre si, o que é interpretado como decorrente de diluição que ocorre com o escoamento superficial. No período de estiagem há maior concentração e maior correlação dos elementos na água. Além disto, no período de chuvoso a adição de compostos agrícolas é drasticamente reduzida já que não é a época de plantio.

A correlação mais expressiva foi a do cálcio com bicarbonato com 97\% retratando a influência geogênica pelo grupo Ibiá que é composto de carbonatos. Sabe-se que a alcalinidade associa-se a dureza da água e os elementos cálcio e magnésio influenciam na determinação dela, porém na área de estudo a dureza é reduzida tendo uma probabilidade 
maior de acumular substâncias tóxicas na água. O bicarbonato correlaciona também com o cloro com $89 \%$ retratando possível relação com resíduos domésticos devido as maiores concentrações encontradas estarem dentro do perímetro urbano

O cloreto com o cálcio se correlacionaram com $85 \%$. Sabe-se que na região do Cerrado existe deficiência de cálcio que limita a produção agrícola, e uma importante fonte de cálcio é na forma de cloreto de cálcio que contribui para ampliar a fertilidade dos solos, com redução de $\mathrm{pH}$ e é essencial para que microrganismos transformem os restos das culturas em húmus e forneça nutrientes ao solo (NOVAIS et al., 2007).

A correlação entre cloreto e magnésio é de $84 \%$ e se mantém na comparação entre as estações seca e chuvosa. O magnésio é um nutriente indispensável ao crescimento das plantas, pois desempenha um papel essencial na constituição da clorofila, base da fotossíntese. Em solos lixiviados da região em função do baixo teor do magnésio é adicionado cloreto de magnésio que fornece uma relação de equilíbrio entre $\mathrm{Mg}^{2+}, \mathrm{Ca}^{2+}$ e $\mathrm{K}^{+}$na solução do solo. A manutenção da forte correlação entre estes íons é atribuída à menor estabilidade do sal aplicado na agricultura (VEIGA et al., 2005).

Sendo assim a fonte destes elementos é considerada como derivada de atividade agrícola e doméstica, apresentando caráter antropogênico na maior parte de suas correlações. As correlações são mais significativas no período seco por ser nessa época que ocorre a adição dos compostos agrícolas no solo, durante o preparo para o plantio. No período chuvoso a perda de correlação é decorrente de diluições, misturas e trocas devidas ao escoamento superficial das águas de chuva naturalmente com baixa mineralização total.

\subsection{Classificação das Águas}

O diagrama triangular de Piper tem sido o método mais eficiente para classificar quimicamente às águas subterrâneas, pois demonstram a abundância relativa dos elementos principais, além de avaliar a evolução química da água indicando diferenças e similaridades entre amostras (MESTRINHO, 2008) e é utilizado para classificar grupos de águas quanto aos íons dominantes. Ele consiste em dois triângulos, um para cátions e outro para ânions e um losango ao centro. Os três eixos triangulares de cátions são utilizados para concentrações de $\mathrm{Ca}^{+2}, \mathrm{Mg}^{+2}$ e a soma de $\mathrm{Na}^{+}+\mathrm{K}^{+}$. Já o triângulo de ânions é construído com os eixos íons $\mathrm{Cl}^{-}$, $\mathrm{SO}_{4}{ }^{-2}$ e a soma de $\mathrm{HCO}_{3}^{-}+\mathrm{CO}_{3}{ }^{2-}$. Assim, cada análise de água resulta em um ponto no triângulo de ânions e um ponto no triângulo de cátions. Estes pontos são projetados 
diagonalmente para cima e paralelamente nas diagonais do diagrama até o seu ponto de interseção no losango central (PIPER, 1944).

No diagrama Piper a classificação dos tipos de água é baseada na localização do ponto plotado no triângulo dos íons, determinando assim, as fácies químicas da água. Para esse trabalho, a classificação das águas visou complementar a interpretação dos resultados analíticos, determinando com isso a importância dos íons cálcio, magnésio e bicarbonato no sistema, uma vez que são os principais constituintes da matriz iônica das águas em estudo (MESTRINHO, 2008). Os dados hidrogeoquímicos da água foram submetidos a um balanço iônico e erro prático das análises.

Ao analisar os pontos plotados no diagrama, nota-se uma distribuição concentrada, retratando a especificidade da água. $\mathrm{O}$ cátion dominante nas águas é o $\mathrm{Ca}^{2+}$, seguido do $\mathrm{Na}^{+}$. $\mathrm{O}$ ânion presente é o $\mathrm{HCO}_{3}^{-}$. No triângulo de cátions, nenhuma amostra situou-se no campo de águas magnesianas, e no triângulo de ânions, nenhuma amostra situa-se dentro do teor de $\mathrm{Cl}^{-} \mathrm{e}$ $\mathrm{SO}_{4}{ }^{2-}$. Sendo assim, as águas superficiais do córrego Campo Alegre podem ser classificadas como Águas Bicarbonatadas Cálcicas e/ ou Sódicas. A divisão dos pontos plotados no diagrama de Piper do período seco e chuvoso (Figuras 5.8 e 5.9) foram agrupados do seguinte modo: pontos 1 e 2 cor preta, ponto 3 cor vermelha, ponto 4 ao 7 cor roxa, ponto 8 cor azul, ponto 9 ao 12 cor verde e ponto 13 ao 17 rosa. No período seco todos os pontos concentraram no campo ânions, águas bicarbonatadas. No campo cátion foram assim classificadas: pontos 1 e 2 águas cálcicas e mistas, ponto 3 águas mistas, pontos 4 ao 7 águas cálcicas e mistas, ponto 8 águas sódicas, pontos 9 ao 12 águas cálcicas e sódicas e pontos 13 ao 17 águas cálcicas. No período chuvoso permaneceram todos os pontos concentrados no campo ânions somente em águas bicarbonatadas. No campo dos cátions, os pontos 4 ao7 situaram-se em águas mistas e os demais pontos em águas bicarbonatadas cálcicas.

A classificação das águas quanto aos íons predominantes foi, de modo geral, bicarbonatadas cálcicas, em ambas as campanhas analisadas (período seco e chuvoso). No entanto, ao analisar a influência da seca observam-se algumas alterações (Figura 5.8), no ponto P8 elas são bicarbonatadas sódicas e nos pontos P9 ao P12 classificadas como mista para cátions. No período chuvoso, as águas dos pontos P8 ao P12 diferem das demais (bicarbonatadas cálcicas) sendo classificadas como bicarbonatadas sódicas.

A utilização do diagrama de piper na classificação da água superficial do Córrego Campo Alegre foi importante, pois foi capaz de verificar qual a relação entre o substrato e das 
águas subterrâneas e suas influências na determinação dos tipos de águas encontradas. E levanta oportunidade para estudos futuros de comparar esses dois tipos de água superficial e subterrânea para verificar as mudanças sofridas.

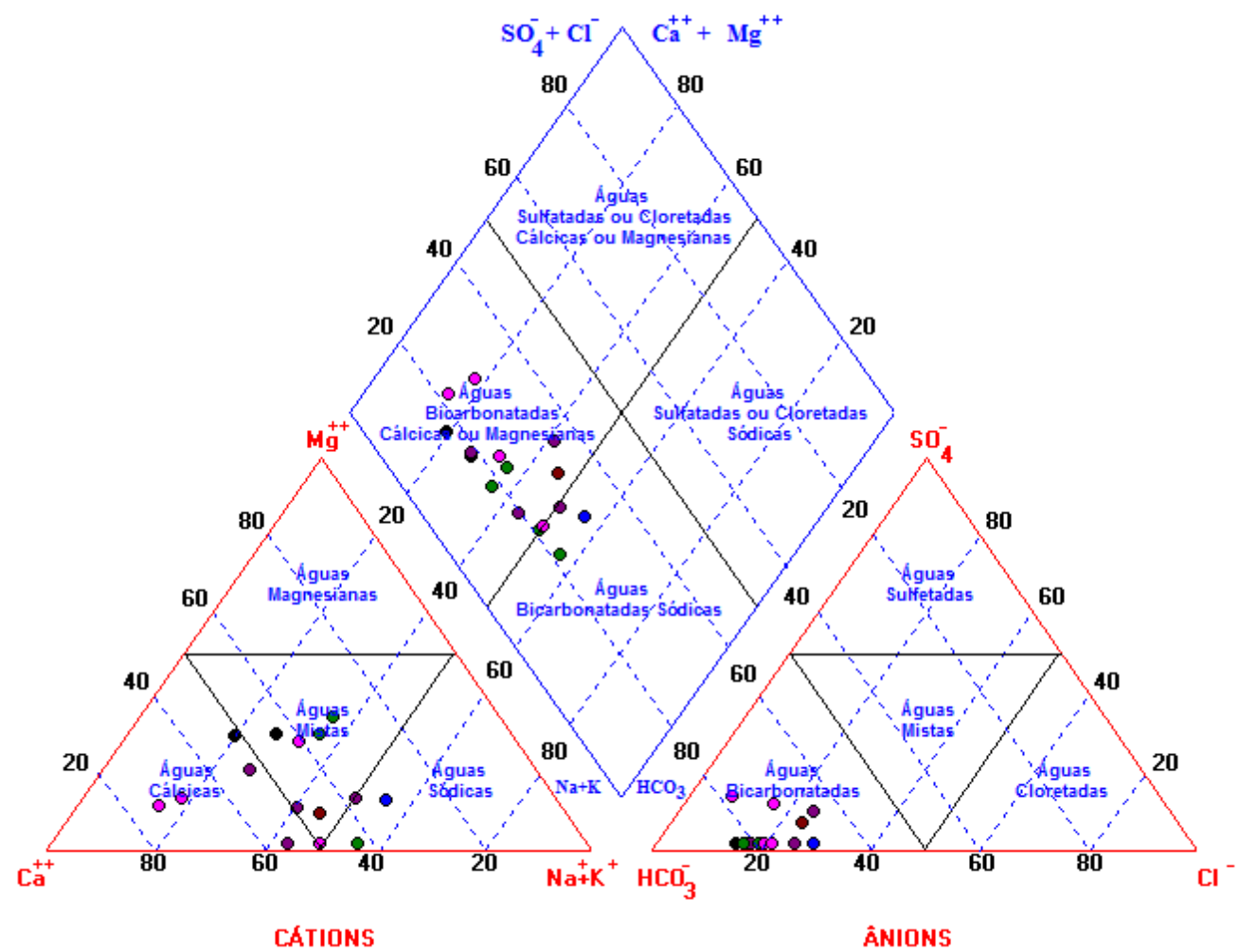

Figura 5.8 - Diagrama de Piper para as amostras de água do córrego Campo Alegre, período seco. 


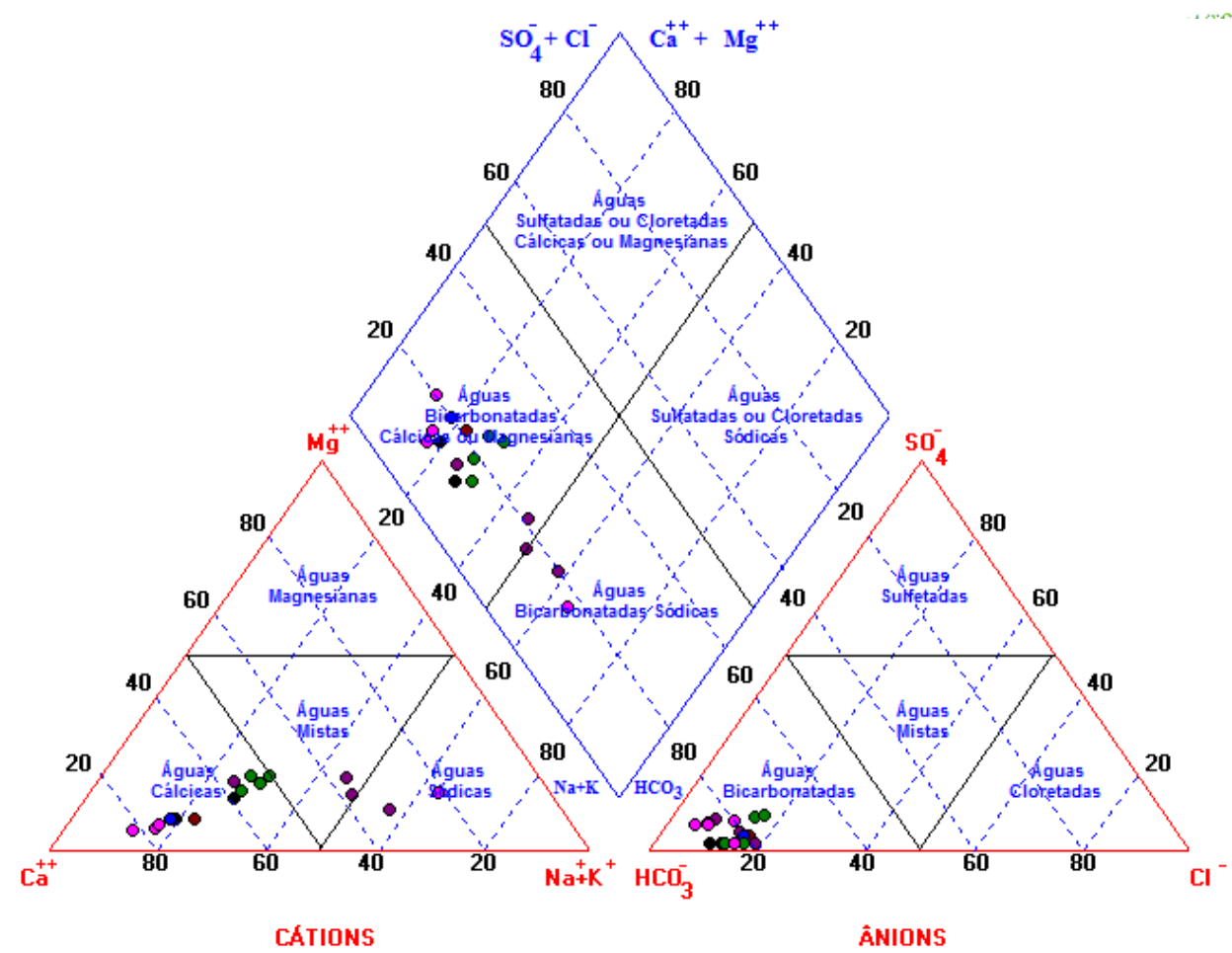

Figura 5.9 - Diagrama de Piper para amostras de água do córrego Campo Alegre período chuvoso.

\subsection{Análise multivariada dos dados geoquímicos}

Os resultados da análise de principais componentes (APC) indicaram a formação de dois grupos na estação seca e três grupos na estação chuvosa, conforme mostram as figuras 5.10 e 5.11 .

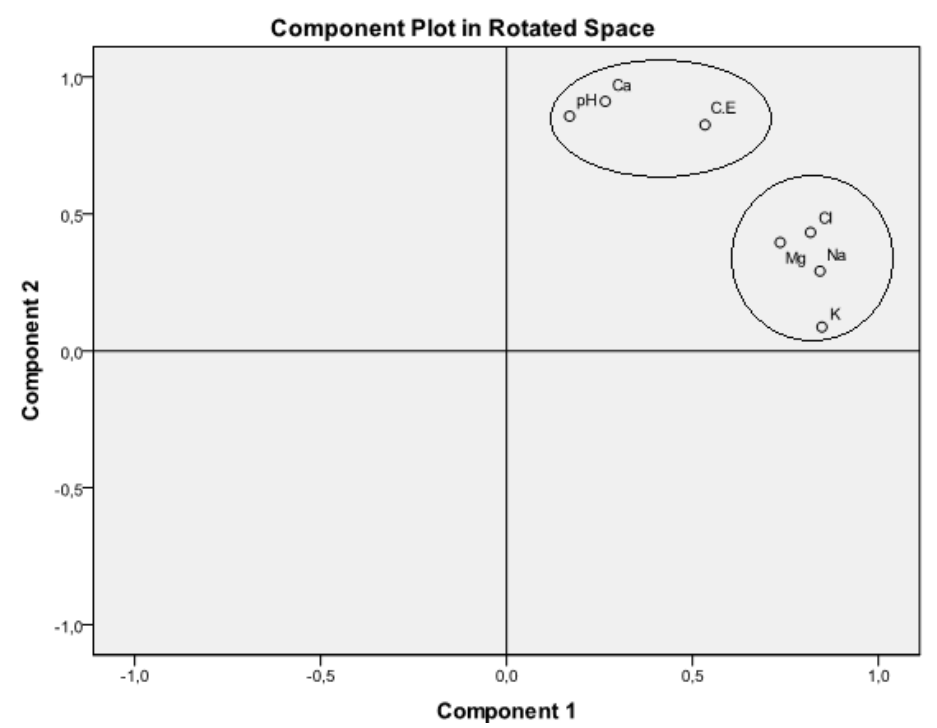

Figura 5.10 - Agrupamento dos parâmetros de acordo os pesos obtidos na APC (PC1 x PC2) na estação seca. 


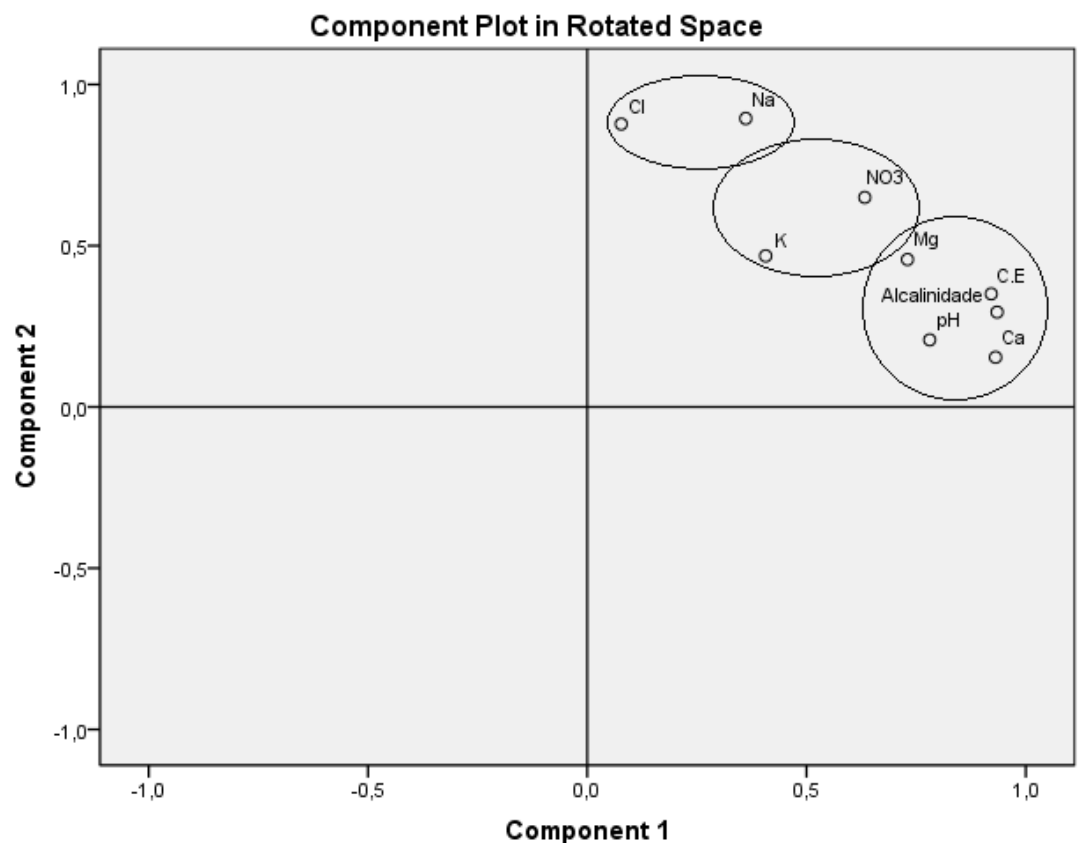

Figura 5.11 - Agrupamento dos parâmetros de acordo os pesos obtidos na APC (PC1 x PC2) na estação chuvosa.

O Grupo 1 na estação seca é representado por três parâmetros: $\mathrm{pH}$, condutividade elétrica e cálcio. A correlação entre tais parâmetros se devem ao fato de o $\mathrm{pH}$ pode-se elevar com uso da calagem, e o cálcio é o principal elemento que determina a condutividade elétrica da água. De acordo com CORRÊA (2000), a calagem é um procedimento agrícola que utiliza pó de dolomito para elevar o pH do solo e reduzir a alta saturação do alumínio para corrigir o solo, e todos os compostos utilizados na correção do solo fazem com que os sais dissolvidos aumentem, consequentemente elevando a condutividade. Segundo ALCARDE (1985), os materiais que se utilizam na correção da acidez dos solos são aqueles que contêm como “constituintes neutralizantes ou princípios ativos os óxidos, hidróxidos, carbonatos e silicatos de cálcio e as adições desses compostos aumentam os índices de sais dissolvidos alterando com isso, a condutividade elétrica". Entretanto pode ser proveniente de fonte natural devido à geologia ser constituída por calcixistos e calcifilitos pertencentes ao grupo Ibiá, pertencente a geologia da área.

O Grupo 2 na estação seca é composto por $\mathrm{Mg}^{2+}, \mathrm{Na}^{+}, \mathrm{K}^{+}$e $\mathrm{Cl}^{-}$em que o $\mathrm{Na}^{+}$e $\mathrm{K}^{+}$ podem ter origem natural pelo intemperismo de rochas e a decomposição de matéria orgânica. A união do $\mathrm{Na}^{+}, \mathrm{K}^{+}$e $\mathrm{Cl}^{-}$pode estar associada a componente antropogênico, em decorrência da presença de matéria orgânica originária de rejeitos na área urbana, além da presença desses elementos no sabão utilizado pelos vários lava-jatos próximos aos pontos de coleta. $\mathrm{O} \mathrm{Na}^{+}$ 
também pode estar presente no sabão e detergente utilizados por diversas atividades humanas. Assim associa-se a descarga de efluentes principalmente vinculado ao sal de cozinha $\left(\mathrm{NaCl}^{-}\right)$, expelido na urina e pode ainda ser vinculado a rações de bovinos (SINGLH et al., 2004). Outro aspecto observado é a ausência de mata ciliar nessas áreas, que favorece o escoamento de poluentes diretamente para o ambiente aquático.

Na estação chuvosa o Grupo1 se modifica e o agrupamento se dá somente pelo $\mathrm{Na}^{+}$e $\mathrm{Cl}^{-}$, retratando assim intensa correlação entre esses elementos e confirmando a fonte por contribuição antrópica (originada de efluentes domésticos).

$\mathrm{Na}$ estação chuvosa o Grupo 2 é constituído por $\mathrm{pH}$, condutividade elétrica, $\mathrm{Ca}^{2+}, \mathrm{Mg}^{2+}$, $\mathrm{K}^{+}$e Alcalinidade. A presença do cálcio pode ter origem geogênica/pedogênica, representado pelo processo de dissolução de rochas carbonáticas, responsável pela produção de águas bicarbonatadas cálcicas $\left(\mathrm{Ca}^{-\mathrm{HCO}_{3}^{-}}, \mathrm{BAIRD1999)}\right.$, conforme classificação de águas do Diagrama de Piper que classifica a maioria em águas bicarbonatadas cálcicas (Figura 5.7 e 5.8). Tendo em vista ainda, o cálcio e o magnésio juntos são elementos liberados pelo intemperismo de alguns minerais primários, como, por exemplo, os feldspatos. (SILVA et al., 2007).

O Grupo 3 na estação chuvosa é composto por $\mathrm{K}^{+}$e $\mathrm{NO}_{3}^{-}$. O potássio é considerado um nutriente essencial para os organismos vivos e existe naturalmente nos corpos de água na forma dissolvida e particulada. Em águas naturais, a concentração de potássio está entre 0,005 mg/L e 0,020 mg/L, no Córrego Campo Alegre a elevação dos níveis de potássio se concentraram na área urbana, apontando como possíveis fontes a partir de efluentes domésticos e atividades agropecuárias. TERNUS (2007) salienta que em cursos d'água desprotegidos de qualquer vegetação marginal, a chuva é outro fator considerado como fonte de $\mathrm{K}^{+}$e de $\mathrm{NO}_{3}^{-}$, que atingem o leito do rio, por meio de lixiviação de solos com elevadas quantidades de fertilizantes das áreas agricultáveis, além de rejeitos de áreas urbanas (esgoto doméstico, efluentes e resíduos sólidos; OUYANG et al., 2006).

$\mathrm{O}$ íon nitrato é considerado a principal forma de nitrogênio associada à contaminação das águas por atividades agropecuárias, devido possivelmente ao fato deste ânion, ser retido nos colóides, tendendo a permanecer mais em solução, principalmente nas camadas superficiais do solo (RESENDE, 2002).

O potássio proveniente da atividade agrícola, aplicado na adubação ocupa as cargas positivas disponíveis, sendo propício ao processo de lixiviação podendo ocasionar 
carreamento para águas subterrâneas (RESENDE, 2002). Além disso, como notado, na área de estudo existe indícios de processo de eutrofização, que contribuem na dispersão desses compostos (BHUMBLA, 2001). O ponto 8 possui a maior concentração desses compostos, localizado a jusante da cidade dessa forma os indícios são ainda são maiores que a origem desses compostos sejam antrópicos.

\subsection{RESULTADOS SEDIMENTOS}

\subsubsection{Mineralogia e Composição química}

A determinação quantitativa dos vários minerais identificados na fração total, argila glicolada e aquecida são compostos por 14 pontos coletados no período seco. Não foram coletados sedimentos nos pontos 15 e 16 uma vez que se tratava de área de tratamento de água das instalações da SANEAGO. Sendo assim, foram detectados como principais minerais o quartzo, a ilita, a caolinita, a gibsita, a goethita, a hematita e o rutilo. Um difratograma característico da área em estudo é apresentado na Figura 5.12.

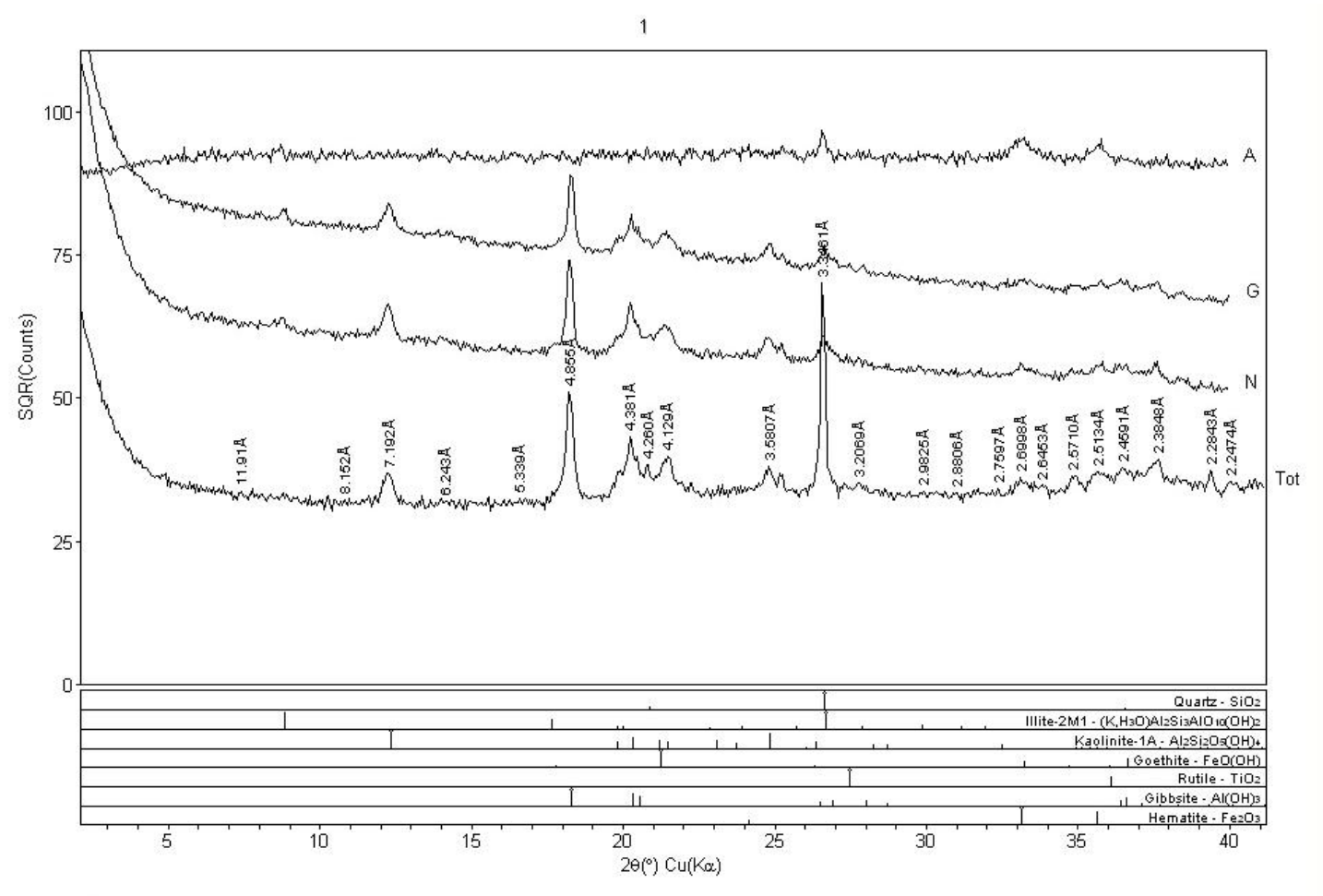

Campus Univ Darby Ribeiro

[RAOO-X|G] Tuesday. November 11, 2014 11:11a MDIIJADE9)

Figura 5.12 - Difratograma dos minerais mais comuns na área de estudo (Ponto1). 
As análises das amostras de fração total apresentaram como constituinte principal o quartzo com os maiores picos nos difratogramas. $\mathrm{O}$ quartzo $\left(\mathrm{SiO}_{2}\right)$ possui suas intensidades de picos registradas em $\mathrm{d} \approx 3,3$, foi o mineral encontrado em maior intensidade, por na geologia local na Formação Verde do Grupo Ibiá conter bandas quartzosas, 4. Nas análises químicas os teores de $\mathrm{SiO}_{2}$ variaram entre 19,5\% a 45,6\%,como consta na Tabela 5.2 podendo estar coligado ao quartzo mas também a caulinita, gibsita e a ilita por serem minerais constituídos por silício.

Nota-se que as concentrações do silício aumentaram em direção à jusante retratando um mineral primário de rochas e solos, muito resistente ao intemperismo e associa-se ao transporte dos solos a jusante dos pontos coletados e erosão das margens dos leitos do córrego, sendo normal a presença deste mineral nas frações mais grossas dos sedimentos de fundo (BERGAYA, 2006).

$\mathrm{O}$ quartzo e o rutilo $\left(\mathrm{TiO}_{2}\right)$ são minerais considerados resistatos e por isso não interferem na concentração de qualquer íon presente em solução, uma vez que os íons presentes nesses minerais não são solubilizados em solução aquosa (PRESS et al., 2006) 
Tabela 5.2 - Resultados dos elementos maiores e sólidos voláteis nos sedimentos de fundo do Córrego Campo Alegre.

\begin{tabular}{cccccccccc}
\hline $\begin{array}{c}\text { Amostra } \\
\text { s }\end{array}$ & $\mathrm{SiO}_{2} \%$ & $\mathrm{Al}_{2} \mathrm{O}_{3} \%$ & $\mathrm{Fe}_{2} \mathrm{O}_{3} \%$ & $\mathrm{CaO} \%$ & $\mathrm{MgO} \%$ & $\mathrm{TiO}_{2} \%$ & $\mathrm{Na}_{2} \mathrm{O} \%$ & $\mathrm{~K}_{2} \mathrm{O} \%$ & $\mathrm{PF} \%$ \\
\hline P01 & 21,7 & 32,8 & 15,7 & $<\mathrm{LQ}$ & $<\mathrm{LQ}$ & 2,2 & 0,6 & 0,4 & 25,9 \\
P02 & 19,5 & 35,5 & 15,3 & 0,8 & $<\mathrm{LQ}$ & 2,3 & 0,9 & 0,2 & 25,5 \\
$\mathbf{P 0 3}$ & 37,5 & 19,7 & 10,6 & $<\mathrm{LQ}$ & $<\mathrm{LQ}$ & 0,6 & 0,3 & 0,3 & 30,6 \\
P04 & 44,4 & 22,6 & 13,8 & 0,7 & 0,3 & 1,8 & 0,9 & 0,9 & 14,5 \\
P05 & 34,4 & 25,2 & 16,9 & $<\mathrm{LQ}$ & 0,2 & 1,8 & 0,5 & 0,8 & 19,8 \\
P06 & 45,6 & 15,6 & 20,6 & $<\mathrm{LQ}$ & 0,2 & 1,6 & 0,6 & 1,1 & 14,3 \\
P07 & 40,5 & 21,0 & 13,7 & $<\mathrm{LQ}$ & $<\mathrm{LQ}$ & 1,5 & 0,6 & 0,5 & 21,7 \\
P08 & 36,5 & 24,0 & 15,1 & 1,4 & 0,4 & 1,7 & 1,0 & 0,6 & 19,3 \\
P09 & 38,0 & 22,1 & 5,8 & 0,5 & $<L Q$ & 1,6 & 0,7 & 0,2 & 30,9 \\
P10 & 32,4 & 24,6 & 15,5 & 0,3 & $<L Q$ & 1,5 & 0,7 & 0,6 & 24,3 \\
P11 & 37,4 & 18,5 & 11,1 & 0,9 & $<L Q$ & 1,4 & 0,7 & 0,3 & 29,7 \\
P12 & 30,5 & 21,8 & 16,0 & $<\mathrm{LQ}$ & 0,2 & 2,4 & 0,8 & 0,7 & 27,0 \\
P13 & 38,7 & 24,8 & 11,9 & 0,7 & 0,2 & 3,1 & 0,9 & 0,9 & 18,8 \\
P14 & 38,4 & 24,0 & 4,9 & 0,7 & 0,2 & 1,7 & 0,6 & 0,6 & 28,8 \\
\hline
\end{tabular}

LQ: Limite de Quantificação.

$\mathrm{O} \mathrm{TiO}_{2}$ variou de $1,4 \%$ a $3,1 \%$ aumentando de montante a jusante, é encontrado na forma de rutilo, e diluído pelos sólidos voláteis, mostra que quanto menor a concentração de Ti maior a concentração dos sólidos voláteis. Nota-se que nos locais onde a concentração do $\mathrm{SiO}_{2}$ é maior, os teores de $\mathrm{Al}_{2} \mathrm{O}_{3}, \mathrm{Fe}_{2} \mathrm{O}_{3}$ e $\mathrm{TiO}_{2}$ são menores. Isso é evidenciado pelo difratograma (Figura 5.12), em que o $\mathrm{SiO}_{2}$ (quartzo) é menos abundante na presença dos minerais $\mathrm{Al}_{2} \mathrm{O}_{3}$ (caulinita, ilita e gibsita), $\mathrm{Fe}_{2} \mathrm{O}_{3}$ (goethita e hematita) e $\mathrm{TiO}_{2}$ (rutilo). Isso também pode ser justificado pela natureza química dos minerais e poder de retenção nos sítios de troca dos colóides. Por outro lado, o $\mathrm{Fe}_{2} \mathrm{O}_{3}$ e o $\mathrm{Al}_{2} \mathrm{O}_{3}$ possuem superfície alta, adsorvendo ânions e cátions em função do pH (OLIVEIRA et al., 2002).

Nas análises pode-se observar outros minerais como a caulinita $\left(\mathrm{Al}_{2} \mathrm{Si}_{2} \mathrm{O}_{5}(\mathrm{OH})_{4}\right.$ e a ilita $\left.\left(\mathrm{KH}_{3} \mathrm{O}\right) \mathrm{Al}_{2} \mathrm{Si}_{3} \mathrm{AlO}_{10}(\mathrm{OH})_{2}\right)$ possuem as intensidades dos seus picos registradas em $\mathrm{d} \approx 7,1 \mathrm{e}$ 9,10, ambos são constituídos por silício e alumínio. Nas análises químicas o $\mathrm{Al}_{2} \mathrm{O}_{3}$ diminuiu de $35,5 \%$ a 15,6\% diminuindo em direção a jusante, essa variação pode ser explicada pela acumulação na laterita ao longo do intemperismo, favorecendo com isso, o acúmulo desses elementos a montante. Os principais minerais constituídos por alumínio além da caulinita e ilita têm-se a gibsita. 
A caulinita, presente em todos os difratogramas, é a principal fonte de Al para os sedimentos (LIMA, 2008). Ela é um argilomineral simples, resultante de minerais primários como os feldspatos e representa um estágio avançado de intemperismo, com baixo teor de elementos maiores e traço (MARTFELD, 2012) e é encontrada em áreas tropicais com baixa capacidade de troca de cátions.

A ilita também é constituída por alumínio, assim como a caulinita, e são conhecidas como argilominerais de substituição. A ilita se caracteriza por ser sintetizada a partir de transformações químicas e físicas de minerais pré-existentes, tais como anfibólios, piroxênios ou feldspatos (LIMA, 2008). Ela está presente em solos recentes com produto da decomposição de rochas, solo e transportadas pela água, depositando em camadas de argila.

A gibsita é composta também por alumínio, como mostra sua fórmula $\left(\mathrm{Al}(\mathrm{OH})_{3}\right)$ sendo responsável também pelo acúmulo dele na composição química nos sedimentos da região de estudo. A gibsita ocorre com frequência em solos bastante evoluídos, com pH baixo (POZZA, et al., 2007). Na área de estudo ela está presente na maioria das amostras formando agregados na porção mais fina, aparecendo na fração normal e na glicolada, representada pela reflexão em $\mathrm{d} \approx 4,84$. Ao longo do leito do córrego Campo Alegre em geral, ela está associada ao intemperismo, sendo formada pelo acúmulo de alumínio dos silicatos formadores das rochas. Como o alumínio é imóvel no ambiente pedogênico forma óxidos hidratados observados em todos os pontos de amostragem (DEER et al,. 1966)

A goethita presente mostrar-se em todos difratogramas com $\mathrm{d} \approx 4,18$, é um óxido de ferro hidratado que pode ser originado a partir de minerais ferro-magnesianos das rochas, como clorita, biotita e sulfetos de ferro (como a pirita). Este mineral apresenta capacidade de adsorção de íons metálicos, por formação de ligações covalentes (RANGEL, 2008). Na composição química o $\mathrm{Fe}_{2} \mathrm{O}_{3}$ oscilando de 4,9 a 20,6 suas baixas concentrações na água, em oposição deste metal nos sedimentos do presente estudo são decorrentes da baixa solubilidade do mesmo nas condições de $\mathrm{pH}$ e Eh do ambiente, caso que ocorre também com o $\mathrm{Al}_{2} \mathrm{O}_{3}$ (SAMPAIO, 2003). No córrego Campo Alegre os minerais dominantes de ferro são goetita e hematita.

A hematita encontrada é um óxido de ferro anidro, $\mathrm{Fe}_{2} \mathrm{O}_{3}$ e foi encontrada apenas em quatro amostras. Este fato já é esperado, pois como sua origem na área de estudo está vinculada aos solos, os óxidos de ferro ocorre mais comumente na forma de goethita (FeO.OH). Sendo que a cor dos latossolos presentes na região é controlada em parte pelos 
óxidos de ferro presentes: latossolos vermelhos contêm hematita, enquanto latossolos amarelos contêm goethita e os latossolos vermelho-amarelos contêm ambos os óxidos (GUIMARÃES, 2005). Na geologia foi identificada uma cobertura detrito-lateríticas ferruginosas que corroboram a origem pedogênica do ferro.

Os elementos cálcio, magnésio, sódio e potássio apresentam origem antrópica em sua maioria. O elemento cálcio na análise de composição química variou de $0,3 \%$ a 1,4\% diminuindo em direção a jusante, mostrou baixa variação dos dados, foi encontrado somente no ponto 10 da mineralogia na forma de calcita $\left(\mathrm{CaCO}_{3}\right)$ podendo referir a interferência pontual, pois o principal uso de cálcio na região é a calagem, que são materiais usados na correção da acidez dos solos constituídos por óxidos, hidróxidos, carbonatos de cálcio e/ou magnésio por ser uma região rica em agricultura é uma área propicia para esse tipo de atividade.

Contudo apresenta dados geológicos que evidenciam a presença de cálcio também na forma de calcixistos e calcifilitos no Grupo Ibiá, o qual se encontra como grupo principal da geologia da área. $\mathrm{O}$ cálcio assim pode ter tanto origem antrópica como pedogênica.

O potássio variou de $0,2 \%$ a $11 \%$ os valores se mostraram baixos e podem ser associados às duas origens pedogênica e antropogênica. Porque o potássio pode estar na forma de ilita $\left.\left(\mathrm{H}_{3} \mathrm{O}\right) \mathrm{Al}_{2} \mathrm{Si}_{3} \mathrm{AlO}_{10}(\mathrm{OH})_{2}\right)$, outra possível fonte são os fertilizantes utilizados na produção agrícola, por sua reserva nos solos do cerrado ser muito restrita e insuficiente para suprir as necessidades das plantas.

O magnésio e o sódio não foram encontrados nos difratogramas. O magnésio teve baixa variação ficando em 0,2 na maioria dos pontos. É considerado um macronutriente, possui um comportamento geoquímico semelhante ao cálcio e, geralmente, estão sempre acompanhados, forma sais solúveis. Por não ser um elemento comum na geologia local, tem sua presença relacionada a fertilizantes agrícolas, apresentando sua origem antropogênica.

O sódio teve variação de 0,3 a 1,0, tem origem em produtos domésticos de limpeza como sabão, detergentes, entre outros e fossas mal construídas que permitem a dispersão de lançamento de esgotos no córrego, outro fator seria na agricultura, pois o sódio é considerado um elemento eficaz no aumento da produção da planta, mostrando caráter antropogênico também.

Estes minerais presentes nos sedimentos são elementos igualmente pedogênicos, embora não tenha sido ainda suficientemente investigado. E não pode ser considerados 
geogênicos pelo solo característico da região latossolo possui uma profundidade grande de 10 a 20 m não tendo ligação direta a rocha.

\subsubsection{Matriz de Correlação}

A amostragem foi realizada no período seco, os resultados das análises de sedimento com 99\% apresentam elevado grau de significância e mostram excelente grau de confiança sendo considerando os valores entre 0,5 a $50 \%$ de correlação. Os valores foram considerados com correlação significativa quando $\mathrm{R}^{2} \geq 50 \%$, como pode ser visto na Tabela 5.3.

Os valores em vermelho representam os valores a partir de 0,5 e os valores de azul representam valores a partir de 0,8 indicam os parâmetros que proporcionam melhor relação entre si. Conforme observado na matriz de correlação, os valores mais significativos e com melhor índice de correlação, entre 80 e 90\% foram o K com La $(0,98)$; Cu com Ni $(0,96)$ e com Mo $(0,93)$; V com Cd $(0,87)$ e com Ni $(0,90)$; Co com Sr $(0,85)$; La com Y $(0,88)$; Cu com $\mathrm{Ba}(0,86)$ e com $\mathrm{Zn}(0,8)$. Esses resultados estão relacionados provavelmente a fatores antropogênicos por nenhum mineral encontrado na mineralogia ser compostos por esses elementos.

Com correlação de 50 a $60 \%$ tem-se o $\mathrm{Na}$ com o Ca $(0,67)$, com Ti $(0,59)$ e com Mg $(0,54)$; K com o Si $(0,51)$ e com Mg $(0,65)$; Y com o Ca $(0,56)$ e com Sr $(0,53)$; Mn com Al $(0,52)$ e com Ba (0,50); Co com Mn (0,59); Ni com Sr (0,74); Cu com Mn (0,65); Zi com Mg $(0,51)$ e com Ba $(0,68)$; Cd com Cr $(0,59)$ e com Mo $(0,77)$. Já nesses resultados o Ti, Mg, Al e o $\mathrm{Si}$ apareceram minerais, podendo estes ser associados a fatores geogênicos e/ou pedogênicos. 
Tabela 5.3 - Correlação de Pearson sedimento de fundo. Os valores em vermelho apresentam correlação em que R $\geq 50 \%$.

\begin{tabular}{|c|c|c|c|c|c|c|c|c|c|c|c|c|c|c|c|c|c|c|c|c|c|c|}
\hline & $\mathrm{SiO}_{2}$ & $\mathbf{A l}_{2} \mathbf{O}_{3}$ & $\mathrm{Fe}_{2} \mathrm{O}_{3}$ & $\mathrm{CaO}$ & $\mathrm{MgO}$ & $\mathrm{TiO}_{2}$ & $\mathrm{Na}_{2} \mathrm{O}$ & $\mathrm{K}_{2} \mathrm{O}$ & PF & $\mathrm{Sr}$ & Ba & $\mathbf{Y}$ & La & $\mathbf{V}$ & $\mathrm{Cr}$ & Mo & Mn & Co & $\mathbf{N i}$ & $\mathrm{Cu}$ & Zn & Cd \\
\hline $\mathrm{SiO}_{2}$ & 1,0 & & & & & & & & & & & & & & & & & & & & & \\
\hline $\mathrm{Al}_{2} \mathrm{O}_{3}$ & $-0,9$ & 1,0 & & & & & & & & & & & & & & & & & & & & \\
\hline $\mathrm{Fe}_{2} \mathrm{O}_{3}$ & $-0,2$ & 0,1 & 1,0 & & & & & & & & & & & & & & & & & & & \\
\hline $\mathrm{CaO}$ & 0,0 & 0,1 & $-0,1$ & 1,0 & & & & & & & & & & & & & & & & & & \\
\hline MgO & 3,6 & $-0,1$ & 0,2 & 0,5 & 1,0 & & & & & & & & & & & & & & & & & \\
\hline $\mathrm{TiO}_{2}$ & $-3,3$ & 0,5 & 0,2 & 0,2 & 0,3 & 1,0 & & & & & & & & & & & & & & & & \\
\hline $\mathrm{Na}_{2} \mathrm{O}$ & $-0,1$ & 0,2 & 0,1 & 0,7 & 0,5 & 0,6 & 1,0 & & & & & & & & & & & & & & & \\
\hline $\mathbf{K}_{2} \mathbf{O}$ & 0,5 & $-0,3$ & 0,5 & $-0,1$ & 0,7 & 0,3 & 0,2 & 1,0 & & & & & & & & & & & & & & \\
\hline PF & $-0,4$ & 0,0 & $-0,6$ & $-0,1$ & $-0,6$ & $-0,3$ & $-0,4$ & $-8,3$ & 1,0 & & & & & & & & & & & & & \\
\hline Sr & $-0,5$ & 0,4 & 0,4 & $-0,1$ & $-0,1$ & 0,9 & $-0,2$ & $-2,4$ & 0,2 & 1,0 & & & & & & & & & & & & \\
\hline $\mathbf{B a}$ & 0,4 & $-0,2$ & 0,3 & $-0,1$ & 0,3 & 0,0 & 0,0 & 0,4 & $-0,5$ & $-0,1$ & 1,0 & & & & & & & & & & & \\
\hline $\mathbf{Y}$ & $-0,5$ & 0,2 & 0,2 & 0,6 & 0,0 & 0,4 & 0,2 & $-0,7$ & 0,2 & 0,5 & $-0,1$ & 1,0 & & & & & & & & & & \\
\hline La & $-0,3$ & 0,1 & 0,2 & 0,1 & 0,1 & 0,4 & 0,4 & 1,0 & 0,1 & 0,2 & 0,1 & 0,9 & 1,0 & & & & & & & & & \\
\hline $\mathbf{V}$ & $-0,1$ & 0,1 & 0,1 & 0,0 & $-0,3$ & $-0,2$ & $-0,2$ & 0,0 & 0,0 & $-0,3$ & $-0,3$ & $-0,4$ & $-0,3$ & 1,0 & & & & & & & & \\
\hline $\mathrm{Cr}$ & 0,4 & $-0,3$ & 0,2 & 0,1 & 0,1 & 0,0 & 0,2 & 3,7 & $-0,5$ & $-0,8$ & 0,5 & $-0,5$ & $-0,1$ & 0,3 & 1,0 & & & & & & & \\
\hline Mo & $-0,2$ & 0,2 & 0,1 & $-0,6$ & $-0,3$ & $-0,2$ & $-0,3$ & 0,0 & 0,1 & $-0,1$ & $-0,4$ & $-0,2$ & $-0,3$ & 0,9 & 0,1 & 1,0 & & & & & & \\
\hline Mn & 0,2 & 0,5 & 0,0 & 0,7 & 0,2 & 0,3 & 0,1 & 0,1 & $-0,3$ & 0,2 & 0,5 & $-0,1$ & $-0,1$ & $-0,5$ & $-0,1$ & $-0,5$ & 1,0 & & & & & \\
\hline Co & $-0,4$ & 0,4 & 0,2 & $-0,1$ & 0,0 & 0,3 & $-0,1$ & $-0,1$ & $-0,1$ & 0,9 & 0,1 & 0,4 & 0,1 & $-0,4$ & $-0,6$ & $-0,2$ & 0,6 & 1,0 & & & & \\
\hline $\mathbf{N i}$ & 0,3 & 0,4 & 0,4 & $-0,6$ & 0,2 & 0,4 & 0,0 & 2,2 & $-0,3$ & 0,7 & 0,3 & 0,5 & 0,2 & $-0,3$ & $-0,4$ & 0,1 & 0,5 & 0,9 & 1,0 & & & \\
\hline $\mathrm{Cu}$ & 0,2 & 0,0 & 0,0 & $-0,1$ & 0,2 & 0,1 & 0,0 & 2,4 & $-0,3$ & 0,0 & 0,9 & $-0,2$ & $-0,1$ & $-0,4$ & 0,3 & $-0,5$ & $\mathbf{0 , 7}$ & 0,3 & 1,0 & 1,0 & & \\
\hline $\mathbf{Z n}$ & 0,3 & $-0,1$ & 0,0 & 0,2 & 0,5 & 0,4 & 0,2 & 4,8 & $-0,4$ & 0,0 & $\mathbf{0 , 7}$ & 0,0 & 0,1 & $-0,5$ & 0,2 & $-0,6$ & 0,5 & 0,2 & 0,4 & 0,8 & 1,0 & \\
\hline Cd & 0,1 & $-0,2$ & 0,2 & 0,1 & $-0,2$ & $-0,2$ & $-0,1$ & 1,2 & $-0,1$ & $-0,6$ & $-0,1$ & $-0,4$ & $-0,3$ & 0,9 & 0,6 & $\mathbf{0 , 8}$ & $-0,4$ & $-0,6$ & $-0,4$ & $-0,2$ & $-0,3$ & 1,0 \\
\hline
\end{tabular}




\subsubsection{Análise dos Grupos}

Para a análise de grupos foi utilizado à correlação de Pearson, esta mostrou que os elementos apresentaram comportamentos semelhantes e foram agrupados nos componentes principais que tem como finalidade avaliar os dados que melhor se ajustam a cada um dos elementos. Os resultados explanados encontram-se na Figura 5.13, formando cinco grupos.

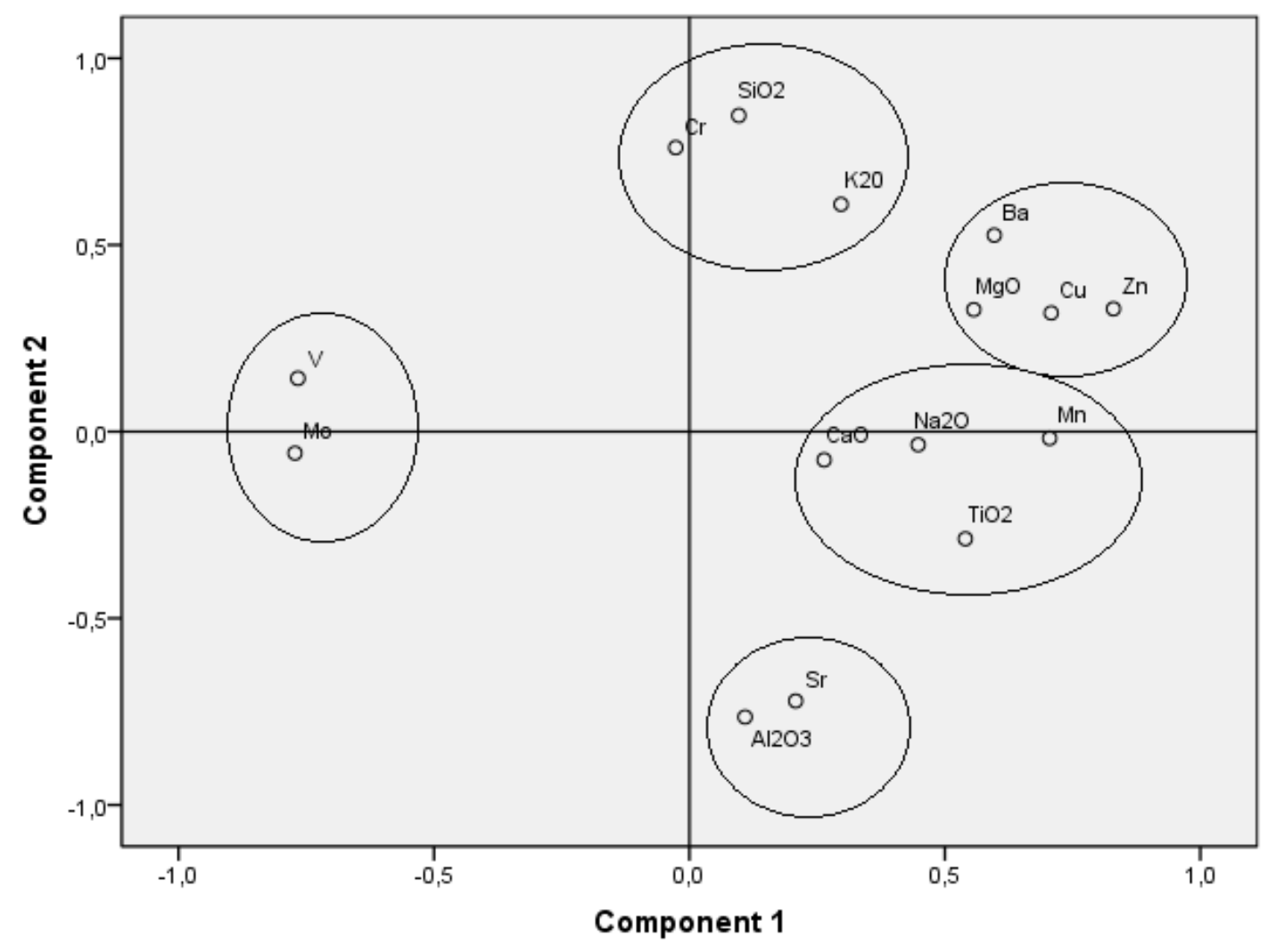

Figura 5.13 - Agrupamento dos elementos de sedimento de fundo utilizando Análise de Componentes Principais.

$\mathrm{O}$ APC 1 é formado por $\mathrm{Cr}, \mathrm{SiO}_{2}$, e $\mathrm{K}_{2} \mathrm{O}$, onde o $\mathrm{Cr}$ e o $\mathrm{K}_{2} \mathrm{O}$ foram associados às atividades antrópicas ligadas a usos de fertilizantes, sendo o potássio na forma de fertilizante químico solúvel (NPK) e o Cr como micronutriente. O cromo pode ser observado em dois estados de oxidação $\mathrm{Cr}^{3+}$ (pouco solúvel e mais estável) e $\mathrm{Cr}^{6+}$ (bastante solúvel e instável), sendo facilmente reduzido por complexos orgânicos. Ele se concentra na camada superficial do solo e sua disponibilidade é afetada pelo pH (BERGMANN,1992). Como neste trabalho não foram realizadas avaliação de especiação de elementos, não se pode afirmar qual a forma do cátion presente. 
O APC2 foi formado pelo $\mathrm{Sr}$ e $\mathrm{Al}$ e são considerados como resultantes da ação do intemperismo sobre as rochas que compõem o substrato. O alumínio está presente na área de estudo a partir de fonte pedogênica representada pela gibsita e argilominerais como ilita e caolinita.

O APC 3 é composto por $\mathrm{Ba}, \mathrm{Mg}, \mathrm{Cu}$ e $\mathrm{Zn}$ sendo considerados nesse caso, como de origem antropogênica. Minerais como calcopirita, calcita e barita apresentam os elementos $\mathrm{Cu}, \mathrm{Zn}$ e $\mathrm{Ba}$ em sua estrutura, entretanto tais minerais não estão presentes no solo ou nas rochas existentes na bacia em estudo. O Ba também pode ser encontrado nos feldspatos substituindo o potássio, o cálcio e o sódio, mas a geologia local não indica a presença deste mineral (ANDRADE, 2011). A origem do Mg pode ser atribuída a atividade antrópica e as principais fontes de contaminação consideradas são a partir da agricultura e o lançamento de esgotos. Já o $\mathrm{Cu}$ e o $\mathrm{Zn}$ presentes podem ser resultantes da utilização de insumos agrícolas como micronutrientes de fertilizantes químicos solúveis.

O APC 4 é representado por $\mathrm{Ca}, \mathrm{Mn}, \mathrm{Na}$ e Ti. A ocorrência de titânio é associada a presença comum no mineral rutilo presentes nas amostras estudados (podendo ser considerada de origem pedogênica), enquanto o cálcio é considerado como oriundo de minerais como calcita e dolomita utilizados na calagem dos solos para viabilizar a agricultura (e portanto de origem antropogênica, FARIA et al., 2001) e também proveniente de calcixistos e calcifilitos podendo também ter origem geogênica. O manganês é considerado como de origem pedogênica, pois óxidos de manganês $(\mathrm{MnO})$ são comumente encontrados nos latossolos (mesmo que em baixas concentrações). O sódio é considerado como de origem antropogênica, a partir de esgotos domésticos e nos sedimentos é encontrado adsorvido em argilominerais.

O APC 5 é composto por $\mathrm{V}$ e Mo, sendo associado a atividade antrópica na região. $\mathrm{O}$ Vanádio é liberado para a atmosfera pela queima de óleo combustível e carvão e/ou pelo intemperismo de rochas e minerais durante a formação do solo na forma de ânion. Ele pode permanecer no solo ou migrar para o ambiente aquático, sendo capaz ser substituir o ferro ou pode ser sorvido pelo óxido de ferro, explicando assim sua presença no solo (SHUQAIR, 2002).

O molibdênio, em princípio, pode ter origem na associação de rochas ácidas magmáticas em solos ácidos e possui média mobilidade. Como na região não ocorrem rochas magmáticas, esta origem não pode ser atribuída nos sedimentos estudados. Outra 
possibilidade reside no fato de que a calagem ou adição de fosfato em solos ácidos pode aumentar a biodisponibilidade de Mo, em razão do íon formar um ácido fraco (McBRIDE, 1994). Ambos possuem comportamento influenciado pelos valores de $\mathrm{pH}$, potencial oxiredução, presença de matéria orgânica e hidróxido de ferro (SHUQAIR, 2002).

Em geral, nota-se que a maioria dos elementos está associada à geologia regional, argilominerias dos solos, e ao transporte e troca catiônicas no solo, principalmente o latossolo, característico da área de estudo, podendo assim relacionar à adsorção química dos elementos presentes na composição mineral e atividades antrópicas, que geram impactos ambientais no corpo hídrico. Com o auxílio do dendograma dos pontos de coleta de sedimento de fundo (Figura 5.14), foram identificados 3 grupos principais, ao considerar uma distância de amalgamação de 5,0. Os resultados de clusters associam-se a comportamentos geológicos e as características de cada elemento associado e a influência antrópica.

O primeiro grupo é composto por pontos de coleta provenientes de ambientes lênticos (P4, P5, P6, P10, P11, P12 P14). Os constituintes deste grupo assemelham-se por ser amostras com pouca influência de elementos originados da ação antrópica. Os pontos P4, P11, P12 e P14 possuem mesma mineralogia. Porém o mesmo grupo é formado por pontos com maior urbanização (P2 e P3; P9 e P10) possuem um grau de similaridade menor que com os demais.

O segundo grupo é constituído por pontos de maior proximidade com a montante, formado por amostras de ambientes lóticos (P1, P8 e P13), assemelham-se pela mineralogia composta por quartzo, caolinita, goethita, rutilo e gibsita. No entanto, os pontos (P1 e P13), evidencia-se em comum a presença de ilita. Pelo ponto 1 ser caracterizado por background, estes pontos representam a geologia local. As diferenças existentes, por sua vez devem ser atribuídas ao grau de interferência antrópica entre os pontos 1 e 8 , pois o ponto 8 é considerado um dos que apresentam os maiores valores dentre os parâmetros analisados.

O grupo 3 representado pelo P7 apresenta característica singular, provavelmente a presença do vanádio. 


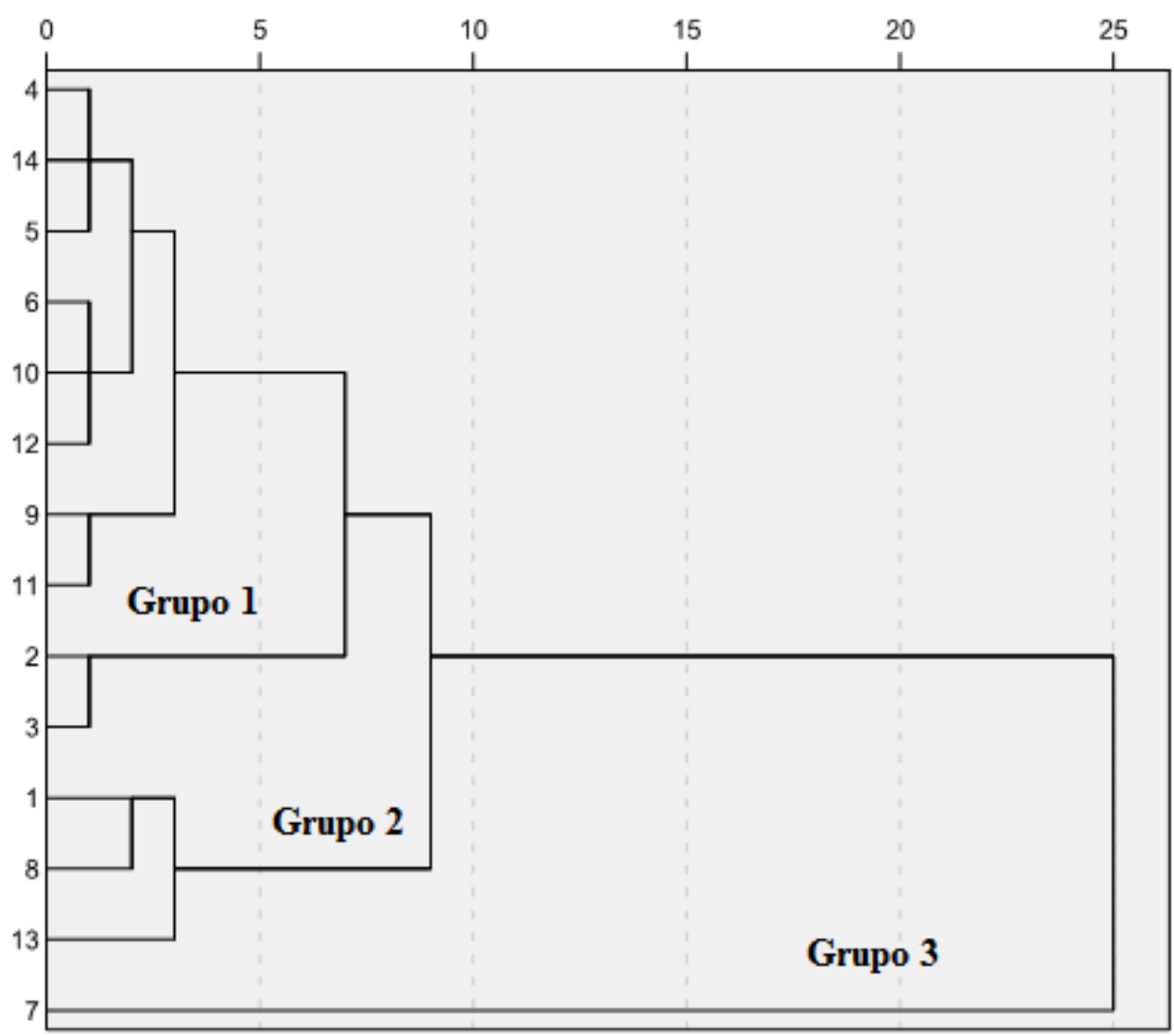

Figura 5.14 - Dendograma dos resultados de amostras de sedimento de fundo.

\subsubsection{Valor de referência}

Os valores de referência geoquímica para as amostras de sedimento da bacia do córrego Campo Alegre foram determinados de acordo à formulação dos índices de geoacumulação e dos valores de background estabelecidos neste estudo (Tabela 5.4). A presença de atividade antrópica na área dificultou o estabelecimento de uma área de controle que possa fornecer valores de background para o cálculo. Durante a coleta foi definido como ponto 1 , situado na nascente do Córrego Campo Alegre onde apresenta vegetação preservada, água de nascente e as principais unidades geológicas (Grupo Ibiá e coberturas detrito- lateríticas ferruginosas) com atividades antrópicas inexistentes ou de pequena quantidade.

Neste estudo os valores de background foram comparados com valores determinados para Bacia Hidrográfica do rio Paracatu e com a média mundial de folhelhos para validação de referência geoquímica para amostras de sedimento da bacia do córrego Campo Alegre. Analisando os valores referências para este estudo, pode-se inferir que a bacia se encontra 
conservada, por enquadrarem com os utilizados em outros projetos no mundo e a maioria dos valores estarem abaixo das referências analisadas.

Tabela 5.4 - Valores de background estabelecidos em diferentes estudos.

\begin{tabular}{|c|c|c|c|}
\hline & Média Mundial $^{(1)}$ & $\mathrm{BG} \mathrm{BRP}^{(2)}$ & Presente Estudo \\
\hline $\mathrm{SiO}_{2}(\%)$ & 69,1 & - & 21,7 \\
\hline $\mathbf{A l}_{2} \mathbf{O}_{3}(\%)$ & 13,5 & 5 & 32,8 \\
\hline $\mathrm{Fe}_{2} \mathrm{O}_{3}(\%)$ & 5,9 & 4,6 & 15,7 \\
\hline $\mathrm{CaO}_{(\%)}$ & 2,6 & - & 0,5 \\
\hline $\operatorname{MgO}_{(\%)}$ & 2,3 & - & 0,1 \\
\hline $\mathrm{TiO}_{2(\%)}$ & 0,72 & - & 2,2 \\
\hline $\mathrm{Na}_{2} \mathrm{O}_{(\%)}$ & 3 & - & 0,5 \\
\hline $\mathbf{S r}$ & 201 & - & 53,4 \\
\hline $\mathbf{C u}_{(\mathbf{p p m})}$ & 24 & 25 & 75,8 \\
\hline $\mathbf{Z n}_{(\mathbf{p p m})}$ & 76 & - & 63,7 \\
\hline $\mathbf{B} \mathbf{a}_{(\mathbf{p p m})}$ & 426 & - & 23,8 \\
\hline $\mathbf{V}_{(\mathbf{p p m})}$ & 98 & - & 144,5 \\
\hline $\mathrm{Cr}_{(\mathbf{p p m})}$ & 88 & - & 8,8 \\
\hline $\mathbf{C d}_{(\mathbf{p p m})}$ & - & - & 0,1 \\
\hline $\mathbf{Y}_{(\mathbf{p p m})}$ & 26 & - & 10,2 \\
\hline Co $($ ppm) & 15 & - & 28,9 \\
\hline $\mathrm{Cr}$ & 88 & 53 & 8,8 \\
\hline $\mathbf{M n}(\mathbf{p p m})$ & 527 & 500 & 254,7 \\
\hline $\mathbf{L} \mathbf{a}_{(\mathbf{p p m})}$ & - & - & 7 \\
\hline Mo (ppm) & - & - & 22 \\
\hline $\mathbf{N i}{ }_{(p p m)}$ & 24 & - & 15,9 \\
\hline
\end{tabular}

(1) WEDEPOHL (1995); (2) MULHOLAND (2009);

(2) BG BRP- valores de background para a bacia hidrográfica do rio Paracatu.

\subsection{5 Índice de Geoacumulação}

Os valores obtidos para o Igeo, são classificados em 6 classes associados ao grau de poluição. A partir do valor background calculou-se o índice de geoacumulação em cada amostra de sedimento para verificar o grau de intensidade de contaminação no qual o córrego Campo Alegre se encontra. A tabela classifica os pontos amostrados de acordo com o índice de geoacumulação obtido para cada elemento (Tabela 5.5). 
Tabela 5.5 - Classificação do Índice de Geo-acumulação.

\begin{tabular}{|c|c|c|c|c|c|c|c|}
\hline & Índice de Geo-: & cumulação & & & & & \\
\hline Pontos & 0 & 1 & 2 & 3 & 4 & 5 & 6 \\
\hline P1 & $\begin{array}{l}\mathrm{SiO}_{2}, \mathrm{Al}_{2} \mathrm{O}_{3}, \mathrm{Fe}_{2} \mathrm{O}_{3}, \mathrm{CaO}, \mathrm{MgO}, \mathrm{TiO}_{2}, \mathrm{Na}_{2} \mathrm{O}, \\
\mathrm{K}_{2} \mathrm{O}, \mathrm{Sr}, \mathrm{Ba}, \mathrm{Y}, \mathrm{La}, \mathrm{V}, \mathrm{Cr}, \mathrm{Mo}, \mathrm{Mn}, \mathrm{Co}, \mathrm{Ni}, \mathrm{Cu}, \mathrm{Zn} \text {, } \\
\mathrm{Cd}, \mathrm{P}, \mathrm{Pb}\end{array}$ & & & & & & \\
\hline $\mathbf{P 2}$ & $\begin{array}{l}\mathrm{SiO}_{2}, \mathrm{Al}_{2} \mathrm{O}_{3}, \mathrm{Fe}_{2} \mathrm{O}_{3}, \mathrm{MgO}, \mathrm{TiO}_{2}, \mathrm{~K}_{2} \mathrm{O}, \mathrm{Ba}, \mathrm{La} \\
\mathrm{Y}, \mathrm{V}, \mathrm{Cr}, \mathrm{Mo}, \mathrm{Mn}, \mathrm{Co}, \mathrm{Ni}, \mathrm{Cu}, \mathrm{Zn}, \mathrm{Cd}, \mathrm{P}, \mathrm{Pb}\end{array}$ & $\begin{array}{l}\mathrm{CaO}, \mathrm{Na}_{2} \mathrm{O} \\
\mathrm{Sr}\end{array}$ & & & & & \\
\hline $\mathbf{P 3}$ & $\begin{array}{l}\mathrm{Al}_{2} \mathrm{O}_{3}, \mathrm{Fe}_{2} \mathrm{O}_{3}, \mathrm{CaO}, \mathrm{TiO}_{2}, \mathrm{Na}_{2} \mathrm{O}, \mathrm{K}_{2} \mathrm{O}, \mathrm{Y}, \mathrm{La}, \\
\text { V,Cr, Mo, Co, Ni, Cd, P, Pb }\end{array}$ & $\begin{array}{l}\mathrm{SiO}, \mathrm{MgO} \\
\mathrm{Cu}, \mathrm{Zn},\end{array}$ & $\begin{array}{l}\mathrm{Sr} \\
\mathrm{Ba} \\
\mathrm{Mn}\end{array}$ & & & & \\
\hline $\mathbf{P 4}$ & $\mathrm{Al}_{2} \mathrm{O}_{3}, \mathrm{Fe}_{2} \mathrm{O}_{3}, \mathrm{TiO}_{2}, \mathrm{Y}, \mathrm{La}, \mathrm{V}, \mathrm{Cr}, \mathrm{Mo}, \mathrm{Cd}, \mathrm{Pb}$ & $\begin{array}{l}\mathrm{SiO}_{2}, \mathrm{CaO}, \\
\mathrm{Na}_{2} \mathrm{O}, \mathrm{MgO}, \\
\mathrm{K}_{2} \mathrm{O}, \mathrm{Co}, \mathrm{Ni} \\
\mathrm{Zn}, \mathrm{P},\end{array}$ & $\begin{array}{l}\mathrm{Ba}, \\
\mathrm{Mn}, \\
\mathrm{Cu},\end{array}$ & $\mathrm{Sr}$ & & & \\
\hline P5 & $\begin{array}{l}\mathrm{Al}_{2} \mathrm{O}_{3}, \mathrm{Fe}_{2} \mathrm{O}_{3}, \mathrm{CaO}, \mathrm{MgO}, \mathrm{TiO}_{2}, \mathrm{Na}_{2} \mathrm{O}, \mathrm{Sr}, \mathrm{La}, \\
\mathrm{Y}, \mathrm{V}, \mathrm{Cr}, \mathrm{Mo}, \mathrm{Co}, \mathrm{Ni}, \mathrm{Cu}, \mathrm{Cd}, \mathrm{Pb}\end{array}$ & $\begin{array}{l}\mathrm{SiO}_{2}, \mathrm{~K}_{2} \mathrm{O} \mathrm{Zn}, \\
\mathrm{P},\end{array}$ & & & & & \\
\hline P6 & $\begin{array}{l}\mathrm{Al}_{2} \mathrm{O}_{3}, \mathrm{Fe}_{2} \mathrm{O}_{3}, \mathrm{CaO}, \mathrm{TiO}_{2}, \mathrm{Na}_{2} \mathrm{O}, \mathrm{Sr}, \mathrm{Y}, \mathrm{La} \\
\mathrm{V}, \mathrm{Cr}, \mathrm{Mo}, \mathrm{Cd}, \mathrm{P}, \mathrm{Pb}\end{array}$ & $\begin{array}{l}\mathrm{SiO}_{2}, \mathrm{MgO} \\
\mathrm{K}_{2} \mathrm{O}, \mathrm{Ni}, \mathrm{Zn}\end{array}$ & $\begin{array}{l}\mathrm{Ba}, \\
\mathrm{Co}, \\
\mathrm{Cu}\end{array}$ & $\mathrm{Mn}$ & & & \\
\hline P7 & $\begin{array}{l}\mathrm{Al}_{2} \mathrm{O}_{3}, \mathrm{Fe}_{2} \mathrm{O}_{3}, \mathrm{CaO}, \mathrm{MgO}, \mathrm{TiO}_{2}, \mathrm{Na}_{2} \mathrm{O}, \mathrm{K}_{2} \mathrm{O} \\
\mathrm{Sr}, \mathrm{V}, \mathrm{Cr}, \mathrm{Mo}, \mathrm{Ni}, \mathrm{Cd}, \mathrm{Pb}\end{array}$ & $\begin{array}{l}\mathrm{SiO}_{2,} \mathrm{Ba}, \mathrm{Y} \\
\mathrm{La}, \mathrm{Co}, \mathrm{Cu} \\
\mathrm{Zn}, \mathrm{P}\end{array}$ & $\mathrm{Mn}$ & & & & \\
\hline P8 & $\begin{array}{l}\mathrm{Al}_{2} \mathrm{O}_{3}, \mathrm{Fe}_{2} \mathrm{O}_{3}, \mathrm{TiO}_{2}, \mathrm{~K}_{2} \mathrm{O}, \mathrm{Y}, \mathrm{La}, \mathrm{V}, \mathrm{Cr}, \mathrm{Mo}, \mathrm{Co} \\
\mathrm{Ni}, \mathrm{Cd}, \mathrm{P}, \mathrm{Pb}\end{array}$ & $\begin{array}{l}\mathrm{SiO}_{2}, \mathrm{MgO}, \\
\mathrm{Na}_{2} \mathrm{O}, \mathrm{Sr}, \mathrm{Ba}, \\
\mathrm{Cu}, \mathrm{Zn}\end{array}$ & $\begin{array}{l}\mathrm{CaO}, \\
\mathrm{Mn},\end{array}$ & & & & \\
\hline P9 & $\begin{array}{l}\mathrm{Al}_{2} \mathrm{O}_{3}, \mathrm{Fe}_{2} \mathrm{O}_{3}, \mathrm{CaO}, \mathrm{MgO}, \mathrm{TiO}_{2}, \mathrm{Na}_{2} \mathrm{O}, \mathrm{K}_{2} \mathrm{O}, \\
\mathrm{V}, \mathrm{Cr}, \mathrm{Mo}, \mathrm{Mn}, \mathrm{Co}, \mathrm{Ni}, \mathrm{Cu}, \mathrm{Zn}, \mathrm{Cd}, \mathrm{P}, \mathrm{Pb}\end{array}$ & $\begin{array}{l}\mathrm{SiO}_{2}, \mathrm{Sr}, \mathrm{Ba}, \\
\mathrm{Y}, \mathrm{La},\end{array}$ & & & & & \\
\hline P10 & $\begin{array}{l}\mathrm{SiO}_{2}, \mathrm{Al}_{2} \mathrm{O}_{3}, \mathrm{Fe}_{2} \mathrm{O}_{3}, \mathrm{CaO}, \mathrm{MgO}, \mathrm{TiO}_{2}, \mathrm{Na}_{2} \mathrm{O}, \\
\mathrm{K}_{2} \mathrm{O}, \mathrm{V}, \mathrm{Cr}, \mathrm{Mo}, \mathrm{Cu}, \mathrm{Cd}, \mathrm{P}, \mathrm{Pb}\end{array}$ & $\begin{array}{l}\mathrm{Ba}, \mathrm{Y}, \mathrm{La}, \mathrm{Mn}, \\
\mathrm{Co}, \mathrm{Zn},\end{array}$ & & & $\mathrm{Sr}$ & & \\
\hline P11 & $\begin{array}{l}\mathrm{Al}_{2} \mathrm{O}_{3}, \mathrm{Fe}_{2} \mathrm{O}_{3}, \mathrm{MgO}, \mathrm{TiO}_{2}, \mathrm{Na}_{2} \mathrm{O}, \mathrm{K}_{2} \mathrm{O}, \mathrm{Sr}, \\
\mathrm{V}, \mathrm{Cr}, \mathrm{Mo}, \mathrm{Mn}, \mathrm{Co}, \mathrm{Ni}, \mathrm{Cd}\end{array}$ & $\begin{array}{l}\mathrm{SiO}_{2}, \mathrm{CaO}, \mathrm{Ba}, \\
\mathrm{Cu}, \mathrm{Zn}, \mathrm{P}, \mathrm{Pb}\end{array}$ & $\begin{array}{l}\text { Y, } \\
\text { La, }\end{array}$ & & & & \\
\hline P12 & $\begin{array}{l}\mathrm{SiO}_{2}, \mathrm{Al}_{2} \mathrm{O}_{3}, \mathrm{Fe}_{2} \mathrm{O}_{3}, \mathrm{CaO}, \mathrm{MgO}, \mathrm{TiO}_{2}, \mathrm{Na}_{2} \mathrm{O}, \\
\mathrm{V}, \mathrm{Cr}, \mathrm{Mo}, \mathrm{Ni}, \mathrm{Cd}, \mathrm{Pb}\end{array}$ & $\begin{array}{l}\mathrm{K}_{2} \mathrm{O}, \mathrm{Sr}, \mathrm{Ba}, \\
\mathrm{Y}, \mathrm{La}, \mathrm{Co}, \mathrm{Cu}, \\
\mathrm{Zn}, \mathrm{P}\end{array}$ & & $\mathrm{Mn}$ & & & \\
\hline P13 & $\begin{array}{l}\mathrm{Al}_{2} \mathrm{O}_{3}, \mathrm{Fe}_{2} \mathrm{O}_{3}, \mathrm{TiO}_{2}, \mathrm{Y}, \mathrm{La}, \mathrm{V}, \mathrm{Cr}, \mathrm{Mo}, \mathrm{Co}, \mathrm{Ni} \\
\mathrm{Cd}, \mathrm{Pb}\end{array}$ & $\begin{array}{l}\mathrm{SiO}_{2}, \mathrm{CaO}, \\
\mathrm{MgO}, \mathrm{Na}_{2} \mathrm{O} \\
\mathrm{K}_{2} \mathrm{O}, \mathrm{Ba}, \mathrm{Cu}, \\
\mathrm{Zn}, \mathrm{P},\end{array}$ & $\mathrm{Mn}$ & $\mathrm{Sr}$ & & & \\
\hline P14 & $\begin{array}{l}\mathrm{Al}_{2} \mathrm{O}_{3}, \mathrm{Fe}_{2} \mathrm{O}_{3}, \mathrm{MgO}, \mathrm{TiO}_{2}, \mathrm{Na}_{2} \mathrm{O}, \mathrm{K}_{2} \mathrm{O}, \mathrm{Y}, \mathrm{La}, \\
\mathrm{V}, \mathrm{Cr}, \mathrm{Mo}, \mathrm{Co}, \mathrm{Ni}, \mathrm{Pb}\end{array}$ & $\begin{array}{l}\mathrm{SiO}_{2}, \mathrm{CaO}, \mathrm{Cu}, \\
\mathrm{Ba}, \mathrm{Mn}, \mathrm{Zn}, \mathrm{P},\end{array}$ & $\mathrm{Sr}$ & & & & \\
\hline
\end{tabular}


Avaliando a Tabela 5.5 em questão, notou-se um comportamento distinto entre o ponto 10 e os demais pontos estudados. O ponto 10 está localizado próximo à montante da bacia, porém no ponto da barragem da represa da SANEAGO que não é utilizada para tratamento e sim percurso comum do córrego, apresentou classe 4 (Fortemente poluído) para Sr. Em seguida os pontos 4, 6, 12 e 13 apresentou classe 3 (Moderadamente à Fortemente poluído) para $\mathrm{Sr}$ e Mn. O Sr é encontrado na forma de carbonato (estroncianita). A similaridade dos raios iônicos do cálcio e estrôncio permite que este substitua o primeiro nas redes iônicas de suas espécies minerais, o que provoca a grande distribuição do estrôncio (WEDEPOHL, 1978). O cálcio nos difratogramas ocorreu somente no ponto 10 , o estrôncio pode ter o substituído, justificando com isso a presença do Sr na maioria das classes do Igeo.

Os pontos 3, 4, 6, 7, 8, 11, 13 e 14 estão na classe 2 (moderadamente poluído), representada pelo $\mathrm{Sr}, \mathrm{Ba}, \mathrm{Mn}, \mathrm{Co}, \mathrm{Cu}$. Embora agrupados, sugerem que estejam associados a duas fontes distintas. O Ba tem como principais fontes antrópicas a fabricação de papel, que usa o bário como pigmento branco, lâmpadas fluorescentes, tintas, visando isso na área de estudo não contém nenhuma fábrica com essas caracterizações, podendo assim estar relacionado com origem geogênica, pode ser encontrado em quantidades-traços de rochas sedimentares, ligado ao manganês, pois segundo HEM (1985) a concentração de bário (Ba) em águas naturais pode ser influenciada pela adsorção de óxidos e hidróxidos, principalmente manganês(Mn), o estrôncio é um elemento presente nos feldspatos e seu comportamento reflete as tendências observadas no bário. Já os elementos cobalto $(\mathrm{Co})$ e cobre $(\mathrm{Cu})$ ligam-se, principalmente, à matéria orgânica, podendo estar associados a fontes antrópicas, pois nos pontos 3 e 8 a grande índice de resíduos domésticos. $\mathrm{O} \mathrm{Cu}$ o pode ainda está presente em veneno agrícola, algicida e o cobalto juntamente com o Mo em fertilizantes importantes na fixação do nitrogênio através do Bradyrhizobium (SFREDO et al.,2010).

Percebe-se que para este córrego, a maioria dos metais analisados foi enquadrado na classe 1 (não poluído a moderadamente poluído), explica-se pela presença de mata ciliar e pouca influência antrópica nessa área. A referência geoquímica para os sedimentos do Córrego Campo Alegre por faixa de concentração, de acordo a formulação de índices de geoacumulação e valores de background (Tabela 5.6). Estes resultados obtidos são valores de referência definidos para o Córrego Campo, mas poderão ser aplicados em outros corpos hídricos da região que possuírem geologia equivalente. 
Tabela 5.6 - Referência geoquímica para as concentrações de sedimentos no córrego Campo Alegre.

\begin{tabular}{|c|c|c|c|c|c|c|c|c|}
\hline \multicolumn{9}{|c|}{ Classe do Igeo } \\
\hline & $\begin{array}{l}\text { MÉDIA } \\
\text { BACKG }\end{array}$ & 0 & 1 & 2 & 3 & 4 & 5 & 6 \\
\hline $\mathrm{SiO2}$ & 22 & $<33$ & $34-65$ & $66-130$ & $131-260$ & $261-520$ & $521-1040$ & $1041-2080$ \\
\hline $\mathrm{Al2O3}$ & 33 & $<49$ & $50-99$ & $100-197$ & $198-394$ & $395-788$ & $789-1576$ & $1577-3153$ \\
\hline $\mathrm{Fe} 2 \mathrm{O3}$ & 16 & $<24$ & $25-47$ & 48-94 & $95-189$ & $190-378$ & $379-756$ & $757-1511$ \\
\hline $\mathrm{CaO}$ & 0 & $<0,68$ & $0,691,36$ & $1,37-2,73$ & $2,74-5,46$ & $5,47-10,91$ & $10,92-21,83$ & $21,82-43,65$ \\
\hline MgO & 0 & $<0,20$ & $0,210,40$ & $0,41-0,81$ & $0,82-1,61$ & $1,62-3,22$ & $3,23-6,45$ & $6,46-12,89$ \\
\hline TiO2 & 2 & $<3,26$ & $3,276,52$ & $6,53-13,03$ & $13,04-26,06$ & $26,07-52,12$ & $52,13-104,24$ & $104,25-208,48$ \\
\hline $\mathrm{Na2O}$ & 1 & $<0,85$ & $0,861,70$ & $1,71-3,40$ & $3,41-6,79$ & $6,80-13,58$ & $13,59-27,17$ & $27,18-54,33$ \\
\hline $\mathrm{K} 2 \mathrm{O}(\%)$ & 0,4 & $<0,65$ & $0,661,30$ & $1,31-2,60$ & $2,61-5,20$ & $5,21-10,41$ & $10,42-20,82$ & $20,83-41,63$ \\
\hline $\mathrm{Sr}$ & 1 & $<1,35$ & $1,362,70$ & $2,71-5,40$ & $5,41-5,20$ & $10,81-21,60$ & $21,61-43,20$ & $43,21-86,40$ \\
\hline $\mathbf{B a}$ & 13 & $<20$ & 21-39 & 40-79 & $80-157$ & $158-314$ & $315-629$ & $630-1258$ \\
\hline $\mathbf{Y}$ & 3 & $<4$ & $5-8$ & $9-16$ & $17-31$ & $32-62$ & $63-125$ & $126-250$ \\
\hline $\mathbf{L a}$ & 4 & $<6$ & 7-11 & $12-23$ & $24-46$ & 47-91 & $92-182$ & 183-365 \\
\hline $\mathbf{V}$ & 334 & $<501$ & $502-1003$ & $1004-2006$ & $2007-4012$ & $4013-8023$ & 8024-16046 & $16047-32093$ \\
\hline $\mathrm{Cr}$ & 60 & $<90$ & 91-181 & $182-362$ & $363-724$ & $725-1447$ & $1448-2894$ & $2895-5789$ \\
\hline Mo & 31 & $<47$ & $48-94$ & $95-187$ & $188-374$ & $375-749$ & $750-1498$ & $1499-2995$ \\
\hline Mn & 39 & $<58$ & $59-116$ & $117-232$ & $233-464$ & $465-929$ & $930-1858$ & $1859-3715$ \\
\hline Co & 3 & $<4$ & $5-8$ & $9-17$ & $18-34$ & $35-67$ & $68-134$ & $135-269$ \\
\hline $\mathbf{N i}$ & 6 & $<9$ & $10-18$ & $19-35$ & $36-71$ & $72-142$ & $143-283$ & $284-566$ \\
\hline $\mathrm{Cu}$ & 46 & $<69$ & $70-138$ & $139-276$ & $277-552$ & 553-1104 & $1105-2208$ & $2209-4416$ \\
\hline $\mathbf{Z n}$ & 34 & 52 & $53-103$ & $104-206$ & $207-413$ & $414-826$ & $827-1651$ & $1652-3302$ \\
\hline Cd & 9 & 13 & $14-27$ & $28-53$ & 54-107 & $108-214$ & $215-427$ & $428-854$ \\
\hline $\mathbf{P}$ & 569 & 853 & $854-1707$ & $1708-3413$ & $3414-6827$ & $6828-13654$ & $13655-27307$ & $27308-54614$ \\
\hline Pb (ppm) & 109 & 164 & $165-328$ & $328-656$ & $657-1313$ & $1314-2626$ & $2627-5251$ & $5252-10502$ \\
\hline
\end{tabular}


A avaliação dos parâmetros físico-químicos e metais da água e do sedimento do Córrego Campo Alegre possibilitou examinar as interferências naturais e antrópicas e correlacioná-las com as possíveis fontes contaminantes que existem na área de estudo. Evidenciou-se nos resultados obtidos dos parâmetros físico-químicos da água: $\mathrm{pH}$, Condutividade, Alcalinidade e Dióxido de Carbono não sofreram grandes alterações, e enquadraram todos dentro dos limites estabelecidos pela CONAMA 357/05 para Classe II.

Considerando valores de metais em água, não houve valores expressivos de alteração da qualidade da água nos períodos analisados. As maiores contribuições antropogênicas foram oriundos de detergentes e sabão em usos domésticos $\left(\mathrm{NaCl}^{-}\right)$dentro do perímetro urbano e utilização de fertilizantes na agricultura pela presença de cálcio bem como calagens para correção do solo. Assim, sua presença na área pesquisada pode ter origem antropogênica e pedogênica. A origem pedogênica é característica da geologia cuja influencia está fortemente ligada à composição do Grupo Ibiá pela calcixistos e calcifilitos.

Com a utilização das técnicas estatísticas aplicadas foi possível identificar os principais processos de modificação da qualidade da água do córrego Campo Alegre, possibilitando identificar a origem em geogênico, pedogênico e antropogênico dos parâmetros analisados. $O$ uso do PCA forneceu uma melhor interpretação dos dados investigados e distinguiu as concentrações dos parâmetros nas estações seca e chuvosa. Notou-se que o estudo em diferentes sazonalidades admitiu verificar que as amostras do período chuvoso são mais abundantes em parâmetros que o período seco, comportamento ocasionado pelo escoamento superficial que carreiam metais e partículas de diversas interferências antrópicas para o ambiente aquático.

A análise mineralógica e o índice de geo-acumulação, permitiu distinguir, de forma multi-elementar, as diferentes influências ocasionadas pelos depósitos minerais no acúmulo de metais nos sedimentos do córrego. As características mineralógicas foram apresentadas, através das análises no raio-X, identificando o quartzo, como componente principal e a caulinita, goethita, gibsita, rutilo, componentes secundários encontrados em todos os pontos amostrados. Com a determinação dos elementos no ICP/OES e EAA foi possível confirmação dos elementos constituintes de cada mineral, observando a capacidade de troca dos minerais 
desta área é baixa, e com a análise química evidenciou-se pouca retenção de metais pelo sedimento, no entanto pode vir a comprometer a qualidade do córrego.

Os índices de geoacumulação apresentaram valores baixos, classifica os sedimentos da região em sua maioria, como não poluídos a moderadamente poluídos. Foram estabelecidos valores de referência, com o intuito de acompanhar as transformações ocorridas no interior desta bacia. Utilizou-se referência média mundial e um trabalho realizado com a mesma linha de pesquisa, associando-os ao ponto 1 confirmado como a área com maior caracterização de ser background, com isso o cálculo do índice de geoacumulação tornam se dados mais significativos para outros estudos. Apesar de indícios de interferência da agricultura o córrego Campo Alegre ainda apresenta um sistema em equilíbrio. 
ALCARDE, J. C. 1985. Corretivos da acidez do solo: características de qualidade. In Seminários sobre corretivos agrícolas., Anais, Piracicaba- SP. 1984. ANDA. Campinas. P. 97-117.

ALLAN, J. D. Strean ecology: structure and function of running waters. London: Chapman \& Hall, 1995. 388 p.

ALMASRI, M. N; Kluarachchi,J. J.; Modeling nitrate contamination of groundwater on agricultural watersheds. Elsevier Journal of Hyddrology,USA, 2007.

ALMEIDA, O. A. Qualidade da Água de Irrigação - Dados eletrônicos - Cruz das Almas: Embrapa Mandioca e Fruticultura, 2010.

ANA. Série: Sistema de Informação sobre Recursos Hídricos: Bacias Hidrográficas do Atlântico Sul. Disponível em:< http://hidroweb.ana.gov.br/cd4/rj.doc $>$. Acesso em: 28 abr de 2013.

ANDRADE, M. G. Elementos-traço A, Ba, Cd, Cr, Cu, Hg, Mo, Ni, Pb, Se e Zn em latossolos e plantas de milho após treze aplicações anuais de lodo de esgoto. Faculdade de Ciências Agrárias e Veterinárias, Unesp, 2011.

APHA. Standard Methods for the examination of water and wastewater. American Public Health Association Water Works Association, Water Environmental Federation, $20^{\text {th }}$ ed., Washigton, 1998.

ARCOVA, F. C. S.; CICCO, V. Características do deflúvio de duas microbacias hidrográficas no laboratório de hidrologia florestal. Walter Emmench, Cunha - SP. Revista do Instituto Florestal de São Paulo, São Paulo, v.9, n.2, p.153-70, 1997.

AZEVEDO, H. A. M. A.; BARBOSA, R. P. Gestão de recursos hídricos no Distrito Federal: uma análise da gestão dos Comitês de Bacia Hidrográfica. Ateliê Geográfico, Goiânia, v. 5, n. 13, p. 162- 182, 2011.

ATLAS DO MEIO AMBIENTE DO BRASIL/EMPRESA DE PESQUISA AGROPECUÁRIA. $2^{\circ}$ edição, Brasília, Embrapa - SPI: Terra Viva, 1996.

BAIRD C.1999. The chemistry PF natural water. In: Baird C. Environmental chemistry. $2^{\mathrm{a}}$ Ed, USA, 421-459.

BARRETO, P. M.; SANTOS, A. C.; GUIMARÃES JÚNIOR, M. P. A.; BRITO, S. S.; TERRA, T. G. R.; LEAL, T. C. A. Relações Ca:Mg e as características agronômicas de plantas forrageiras. Brachiaria brizantha cv. MG-4. Pubvet, v.2, n.38, 2008.

BERGMANN, W. Nutricional disordes of plants: developmentos, visual and analytical diagnosis. New York: Gustv Fischer Verlang Jena, 1992. 741p;. 
BERGAYA, F.; THENG, B. K. G.; LAGALY, G. Handbook of Clay Science: Formation and properties of Clay-Polymer Complexes. $2^{\circ}$ edição, Amsterdam, 2006.

BERNARDI, E. C. S.; PANZIERA G. A. B.; Swarowsky, A bacia hidrográfica como unidade de gestão ambiental. Disciplinarum Scientia. Série: Ciências Naturais e Tecnológicas, Santa Maria, v. 13, n. 2, p. 159-168, 2012.

BHUMBLA, D.K. Agriculture pratices and nitrate pollution of water. Disponível em http://www.caf.wvu.edu/-forage/nitratepollution/nitrate.htm Acesso em 18 de junho de 2013.

BOAVENTURA, G. R. Performance do Espectrômetro de Emissão com Plasma (ICP), SPECTROFLAME FVM03, para Determinação de 20 Elementos Químicos nas Amostras de Referência Geoquímica. DNC-1, W-2, UNB-B1 e UNB-G1, In: Congr. Bras. Geoq., 3º, São Paulo, 1991, Resumos, SBGq, V. II, p. 423-426.

BOLMANN, H. A.; FREIRE, S. M. Avaliação da carga de macro-nutrientes orgânicos no Reservatório do Rio Irai, Região Metropolitana de Curitiba/PR, a partir dos seus tributários principais. In: Seminário do projeto interdisciplinar sobre eutrofização de águas de abastecimento público na bacia do altíssimo Iguaçu, Anais, v.4, pag. 5-7, Curitiba 2003.

BONOTTO, D. M. Avaliação da taxa de intemperismo químico na Bacia do rio Jaú (SP). Dissertação de doutorado, Instituto de Geociências e Ciências Exatas, Universidade Estadual Paulista, Rio Claro, 2011.

BONNET, B. R. P., FERREIRA, L. G., LOBO, F. C. Relações entre qualidade da água e uso do solo em Goiás uma análise à escala da bacia hidrográfica. Revista Árvore, v.32, n.2, p.311-322, Viçosa-MG, 2008.

BORGES, R. B. Gestão dos Recursos Hídricos no Brasil, com foco no Estado de Goiás. Dissertação de Mestrado em Ecologia e Produção Sustentável, Universidade Católica de Goiás, Goiás, 2005.

BORGES, L. O. S. Qualidade da Água e Sedimento na Bacia do Piancó em Anápolis Goiás. (Dissertação de Mestrado) UFG, Goiânia - Goiás, 2009.

BORSATO, V. A.; SOUZA FILHO, E. E. Ação Antrópica, alterações nos geossistemas, variabilidade climática: contribuição ao problema. Revista Formação, Edição Especial, n.13, v.2, Universidade Estadual de Maringá, RN, 2004.

BOTELHO, R. G. M. Planejamento ambiental em microbacias hidrográficas. In: GUERRA, J. T.; SILVA, A. A., BOTELHO, R. G. M (Org) Erosão e conservação dos solos. Rio de Janeiro: Bertrand Brasil, P.269-293, 1999.

BRAGA, B. et al. Introdução à Engenharia Ambiental. $2^{\circ}$. ed. São Paulo: Pearson Prentice Hall, 2005. 318p. 
BRASIL, CONAMA, Conselho Nacional do Meio Ambiente, Resolução n 357, de 17 de março de 2005.

RIGHT, M., PACIORNIK, C. M. Chuva Ácida. Coleção S. O. S. Planeta Terra. São Paulo, Melhoramentos, 1992.

BRUIJNZEEL, L. A. Hydrology of forest plantations in the tropics. In: NAMBIAR, E.K.S.; BROWN, A. G. (ed.). Management of soil, nutrients and water in tropical plantation forests. Canberra: ACIAR, 1997. P.125-67.

CAMPOS, J. E. G.; Hidrogeologia do distrito federal: Bases para a gestão dos recursos hídricos subterrâneos. Revista Brasileira de Geociências, volume 34, 2004.

CARMO, M. S.; BOAVENTURA, G, R. Geoquímica das águas da Bacia hidrográfica do rio Descoberto, Brasília-DF. Química Nova, Vol. 28, No. 4, 565-574, 2005.

CARMO, M. S. Geoquímica de Águas e Sedimentos do Corrente da Bacia Hidrográfica do Rio Descoberto. Instituto de Geociências, Universidade de Brasília- dissertação $\mathrm{n}^{\circ}$ 161, Brasília, 2001.

CARNEIRO, M. A. C.; SOUZA, E. D.; REIS, E. F.; PEREIRA, H. S.; AZEVEDO, R. Atributos físicos, químicos e biológicos de solo de cerrado sob diferentes sistemas de uso e manejo. Revista Bras. Ci. Solo, novembro, 2009.

CARNEIRO, F. M. Análise do estudo de impacto ambiental e qualidade da água- O caso do Açude Atalho- Brejo Santo, Ceará. Mestrado em desenvolvimento e meio ambiente, Universidade Federal do Ceará, Fortaleza, 2002. 15 p.

CARVAlHO, I.G, Fundamentos da Geoquímica dos Processos Exógenos, Ed. Bureau Gráfica e Editora Ltda, Salvador, Bahia, 1995.

CARVALHO, M. A.; Estudo geoquímico da qualidade da água da Bacia do Riacho Fundo-Dissertação de Mestrado, Brasília-DF, 2013.

CARVALHO, P. H. V. Desenvolvimento de método para determinação de resíduos de pesticidas em planta medicinal Cordia salicifolia utilizando as técnicas de MSPD, GC/MS e HPLC-UV. Dissertação de Mestrado, Sergipe, 2009.

CETESB - Companhia de Tecnologia de Saneamento Ambiental. Variáveis de qualidade das águas. São Paulo, 2001.

CETESB- Companhia de Tecnologia de Saneamento Ambiental, 2007 HTTP://www. cetesb.sp.gov.br/Agua/rios/variaveis.asp. Acesso em 10 de outubro de 2013.

CHEN, K., JIAO, J.J., HUANG, J. \& HUANG, R. 2007. Multivariate statistical evaluationof trace elements in groundwater in a coastal area in Shenzhen, China. Environmental Pollution, Volume 147, Issue 3, p. 771-780. 
COELHO, A. M. Fertirrigação. In: COSTA, E. F. da; VIEIRA, R. F.; VIANA, P. A. (Ed.). Quimigação: aplica-ção de produtos químicos e biológicos via irrigação. Brasília, DF: EMBRAPA-SPI, p.201-227,1994.

COELHO, N. A. L. Hidrologia de Encosta na Interface com a Geomorfologia. In Geomorfologia: uma atualização de bases e conceitos/ organização, Antônio José Teixeira Guerra e Sandra Baptista da Cunha. -5 edição- Rio de Janeiro, 2003.

CONAMA. Conselho Nacional do Meio Ambiente. Ministério do Meio Ambiente. Resolução n. 357 de 17 de março de 2005. Diário Oficial da União, Brasília, 2005. 23p.

CORATO, R. M. S.; BOTELHO, R. G. M., in Uso da Microbacia Como Unidade Fundamental de Análise em Ciências Ambientais, 1999.

CORDEIRO, G. G. Qualidade de Água para Fins de Irrigação (Conceitos básicos e práticos), Embrapa Semi Árido, Documento 167, Petrolina, 2001.

CORRÊAA, J. C. 2000 Manejo do uso do solo no município de Querência, MT. Embrapa Cerrados n.26, 40p.

CPRM,

Disponível

em: $\langle$ http://www.cprm.gov.br/arquivos/pdf/geolgoias/geolgoiasmpgeologse.pdf $>$. Acesso: 02/07/2013.

CRUZ, R. C.; TAVARES, I. S. Bacia hidrográfica: aspectos conceituais e práticos. In: RIGHES, A. A. (Org.); BURIOL, G. A. (Org.); BOER, N. (Org.). Água e educação: princípios e estratégias de uso e conservação. Santa Maria, RS: Centro Universitário Franciscano, 2009. cap. 3.

CUBAS, V. A.; $O$ agronégocio do café nas áreas de Cerrado: uma breve análise das empresas localizadas no município de Campo Alegre-Go. Espaço em Revista, v.12, n.1, pag 131-143,2010.

DARDENNE, M. A., FUCK, R. A., D’EL-REY SILVA L. H., PIMENTEL, M. M. 1994) Mapa Geológico - Projeto Rio Veríssimo. Brasília, I.G. UnB, Undergraduate Final Essay).

DEER W.A., HOWIE R.A., ZUSSMAN J. 1966. Minerais Constituintes de Rochas Uma Introdução. Lisboa, Fundação Calouste Gulbenkian, 558p.

DILL, P. R. J. Gestão Ambiental em Bacias hidrográficas. Tese de doutorado, Universidade Federal de Santa Maria, Centro de Ciências Rurais. Santa Maria, RS, Brasil, 2007.

DONADIO, N. M. M.; GALBIATTI, J.A; PAULA, R. C. Qualidade da Água de Nascentes com Diferentes Usos do Solo na Bacia Hidrográfica do Córrego Rico, Revista Eng. Agric., Jaboticabal, v.25, n.1, p.115-125, jan./abr. 2005 - São Paulo, Brasil, 2005. 
DOURADO, J. D.; Elementos traço em sedimentos e Anomalocardia brasiliana (GMELIN,1791) em área sob influência de carcinicultura, salinas da Margarida, Bahia. Programa de pós-graduação em Geoquímica, Instituto de Geociências, Universidade Federal da Bahia, Salvador, 2013.

ECHEVERRIA, R. M.; Avaliação de Impactos Ambientais nos Tributários do Lago Paranoá, Brasília DF. Instituto de Geociências, Universidade de Brasília, 2007.

ESTEVES, F. A. Fundamentos de Limnologia. 2a ed. Rio de Janeiro: Editora Interciência, 1998, 602 p.

FARNHAM, I. M.; JOHANNESSON, K. H.; SINGH, A. K.; HODGE, V. F.; STETZENBACH, K. J.; Anal. Chim. Acta 2003, 490, 123.

FARIA, M. M.; SANCHEZ, B. A. Geoquímica e mineralogia dos sedimentos recentes da Baía de Guanabara(NE setor) e seus principais rios- Rio de Janeiro - Brasil. Anais da Academia Brasileira de Ciências, v.73, Rio de Janeiro, 2001.

FAUST, S. D.; ALY, O. M. (Eds.) 1981. Chemistry of Natural Waters. Butterworths Publishers, Sydney, $400 \mathrm{pp}$

FELTRE, Ricardo, Química Geral, Vol. I, Ed. Moderna, 6 Ed., São Paulo/SP, 2004. http://marisoares.wordpress.com/2009/05/29/origem-da-palavra-salario/. Acesso em 13 abril de 2013.

FERREIRA, A. P (2006). Pesticide impacts in the microbial soil activity and on farmers healthy. Revista Baiana de Saúde Pública. Salvador, v.30 (2), p. 309- 321, dezembro, 2006.

FERRIER, R. C., EDWARD, A. C., HIRST, D. "Water Quality of Scottish Rivers: Spatial and Temporal Trends", The Science of the Total Environment, v.265, pág. 327 - 342, 2001.

FÖRSTNER, U. 1983. Assessment of metal pollution in rivers and estuaries. In: THORNTON, I. (ed.) Applied Environmental Geochemistry. Londres: Academic Press. 395-423pp.

FLORENCIO, B. A. B.; SILVA; E. M.; PIMENTEL, M. R. S.; SOUSA, P. C.; ASSUNÇAO, W. L.; Uso da água na bacia hidrológica do rio São Marcos - Goíás. Dissertação de mestrado. Uberlândia, 2002.

FREITAS, M. B; BRILHANTE, O. M. The importance of water testing for public health in two regions in Rio de Janeio: a focus on fecal coliforms, nitrates, and aluminum. Cad. Saúde Pública, Rio de Janeiro, 2001.

FRIOZO, A. R.; FARIA, R. P. G; FARIA.; J. L. B. Influência da chuva sobre os parâmetros físico-químicos na água da Lagoa do IFMT - Bela Vista. III Congresso 
Brasileiro de Gestão Ambiental, IBEAS - Instituto Brasileiro de Estudos Ambientais, IFMT, Goiânia, 2012.

FRITZSONS, E; MANTOVANI, L. E; NETO, A. C; HINDI, E. C. A influência das atividades mineradoras na alteração do $\mathrm{pH}$ e da alcalinidade em águas fluviais: $\mathrm{o}$ exemplo do rio Capiviari, região do carste paranaense. Revista Eng. Sanit. Ambient., v.14, n.3, Collombro, 2009.

FUNASA, Fundação Nacional de Saúde. Manual prático de análise de água, Brasília, 2004. Disponível em: <http://www.funasa.gov.br/site/wpcontent/files_mf/eng_analAgua.pdf $>$ Acesso em: 13 de abril de 2012

GARCIA, A. V.; OlIVEIRA, E. C. A.; SILVA, G. P.; COSTA, P. P. C.; OLIVEIRA, L. A. Disponibilidade Hídrica e Volume de Água Outorgado na Microbacia do Ribeirão Abóbora, Município de Rio Verde, Estado de Góias. Caminhos de Geografia. Revista on line. Disponível em <http://www.ig.ufu.br/revista/caminhos.html $>$ Acesso em: 23 jul 2013.

GIRARDI, A. Avaliação da qualidade bacteriológica da água das instituições de ensino do município de São Miguel do Oeste/SC. UNOESC, São Miguel do Oeste, 2012.

GOIÁS. Secretaria do Meio Ambiente e dos Recursos Hídricos - SEMARH. Recursos hídricos. 2005.

GREENBERG A. E., CLESCERI, L. S., EALTON A. D (ED).1992. Standard methods for the examination of examination of water and wastewater. 18 ed. Ed.American Public Health Association.

GUEDES, J. A. (a) Geoquímica e Meio Ambiente. Revista GEO Temas, Pau dos Ferros, Rio Grande do Norte, Brasil, v 2, n. 1, p. 145-151, jan/jun., 2012.

GUIMARÃES, A. T. A. Avaliação geoquímica ambiental da barragem do Ribeirão da Cachoeira, Sudoeste do Quadrilátero Ferrífero, Ouro Preto, MG. Dissertação Mestrado Geologia, Fundação Universidade Federal de Ouro Preto, Ouro Preto, 2005.

GURGEL, B. S. Avaliação de impactos ambientais por estudo geoquímico na Bacia do Córrego Rico, Paracatu-MG. Dissertação de Mestrado n 228, Instituto de Geociências, 2007.

HAKANSON, L. Na Ecological risk índex for aguatic pollution control. A sedimentalogical approach Water Research. V.14, p.975-1001, 1980.

HEM, J. D. 1985. Study and Interpretation of the Chemical Characteristics of Natural Water. 3 ed. U.S. GeologicalSurvey Water-Supply Paper, 2254, 263p.

HERNÁNDEZ, R. V. A.; Caracterização dos solos da ilha de Santiago (Cabo Verde) numa perspectiva de sustentabilidade ambiental. Dissertação de Mestrado, Universidade de Aveiro, Cabo Verde, 2005. 
HOLANDA, C. S., MARTINS, I. A. V., CERQUEIRA, M. C., BELL. A., MARCHETTO, $M$. Atividades agropastoris na região Amazônica e seus impactos sobre os recursos hídricos. XVIII Simpósio Brasileiro de Recursos Hídricos. Paraná, 2009.

HOLT, M. S. Sources of Chemical Contaminants and Routes into the Freshwater Environment. Food and Chemical Toxicology, v.38, p.21-27, 2000.

IBGE- Instituto brasileiro de Geografia e Estatística. Disponível em< http://www.ibge.gov.br/cidadesat/xtras/uf.php?coduf=52\&search=Goi\%C3\%A1s. Acesso: 02/07/2013.

INOCÊNCIO, M. E. O proceder e as tramas do poder na territorialização do capital no cerrado. Programa de Pós-graduação em Geografia, Universidade Federal de Goiás, 2010 .

JUNIOR, M. B.; MELLO, J. W. V.; SCHAEFER, C. G. R.; DUSSIN, T. M.; ABRAHÃO, W. A. P.; Valores de referência local e avaliação da contaminação por zinco em solos adjacentes a áreas mineradas no município de Vazante- MG. Revista Brasileira Científica de Solo, Viçosa, 2008.

KAISER, H. F. 1958. The Varimax criteria for analytical rotation in factor analysis. Psychometrika, v.23, 187-200p.

KLEIN, P. B. W. Geoquímica de Rocha Total, Geocronologia de U - Pb e Geologia Isotópica de Sm - Nd das Rochas Ortognáissicas e Unidades Litológicas Associadas da Região Ipameri- Catalão (Goiás). Dissertação Doutorado, Instituto de Geociências, Universidade de Brasília, Brasília, 2008.

KUERTEN, S.; SANTOS, M. L.; SILVA, A., Variação das características hidrossedimentares e geomorfologia do leio do rio Ivaí-PR em seu curso inferior. Unesp, Geociências, V.28,n.2, pág. 143-151,São Paulo,2009.

LACERDA, L. D. 2006. A zona costeira: o domínio das interações. Disponível em: www.institutomilenioestuarios.com.br. Acessado em 11 de maio de 2013.

LANEIRO, C. F. M. Avaliação da biodisponibilidade de metais em solos contaminados por atividades mineiras: métodos químicos, bioquímicos e ecotoxicológicos. Dissertação mestrado, Instituto Politécnico de Beja, Escola Superior Agrária, Beja, 2012.

LEONEL, L. F.; Utilização de bioensaios ecotoxicológicos com Danio rerio (Cypriniformes, Cyprinidae) e análises limnológicas para a avaliação dos ecossistemas aquáticos na bacia hidrográfica dos rios Itaqueri/ Lobo. Dissertação de mestrado, São Carlos, 2012.

LICHT, O. A. B.; A Geoquímica Multielementar na Gestão Ambiental - Identificação e Caracterização de Províncias Geoquímicas Naturais, Alterações Antrópicas da Paisagem, Áreas Favoráveis à Prospecção Mineral e Regiões de Risco para a Saúde no Estado do Paraná, Brasil - Geologia Ambiental (Tese de Doutorado) Curitiba, 2001. 
LIMA, W. P.; ZAKIA, M. J. B. Hidrologia florestal In: RODRIGUES, R. R.; LEITÃO FILHO, H. F. (eds.) Matas Ciliares: conservação e recuperação. São Paulo: Editora Universidade de São Paulo / FAPESP, 2000. cap.3, p.33-44.

LIMA, E. A. M. Avaliação da qualidade dos sedimentos e prognóstico geoquímico ambiental da zona estuarina do rio Botafogo. Pernambuco UFP, 2008.

LIMA, L. M. M.; Mapeamento da suscetibilidade à inundação na bacia hidrográfica do arroio do salso, Porto Alegre - Rs. Dissertação de Mestrado, Porto Alegre-Rs, 2010.

LOPES, A. S. Solos sob cerrado: características, propriedades e manejo. Piracicaba-SP: POTAFOS, 1984, $2^{\text {a }}$ ed. 162p.

MACHADO, L. S.; PASQUALETTO. Diagnóstico hidrológico da Bacia do córrego Caverinha, Goiânia, Go. Projeto Final II, Departamento de Engenharia Ambiental, Universidade Católica de Goiás, Goiás, 2006.

MACHADO, L. E. G., NUNES, E. D., ROMÃO, P, A. Análise da influência da topografia na variação sazonal de fitofisionomias na bacia do Rio Veríssimo-GO. Anais XIV Simpósio de Sensoriamento Remoto, Universidade Federal de Goiás, p. 2817-2822, Natal, Abril, 2009.

MAIA, P. D. Estudo Geoquímico de Metais em Sedimentos de Lago Paranoá-DF. Dissertação de Mestrado em Geociências-Instituto de Geociências/ UnB, Brasília, 2003.

MAIA, Y. L. M.; Análise Multielementar em Água e Sedimentos de Corrente da Bacia Hidrográfica do rio Meia Ponte na Região Metropolitana de Goiânia e sua relação com a Saúde. Goiânia, 2004.

MATOS, P. F; PESSÔA, L. S.; O agronegócio no cerrado do sudeste goiano: uma leitura sobre Campo Alegre de Goiás, Catalão e Ipameri. Sociedade e Natureza, n.1, 37-50, Uberlândia, 2012.

MARTFELD, M. I. D. Avaliação da qualidade de água no alto curso do rio Xingu: Bacia do Rio das Pacas, Querência - MT. Dissertação de Mestrado, Instituto de Geociências, Brasília, 2012.

McBRIDE, M.B. Environmental chemistry of soils. New York, Oxford University Press, 1994. 406p.

McGRATH, S. P.; ZHAO, F. J.; DUNHAM, S. L.; CROSLAND, A. R.; COLEMAN, K. Long-term changes in the extractability and bioavailability of zinc and cadmium after sludge application. J. Environ. Qual. 29, pág.875 - 883, 2000.

MESTRINHO, S. S. P. Geoquímica das Águas Subterrâneas. In: FEITOSA, A. C. F. E. et al. (Coord). Hidrogeologia: Conceitos e aplicações. $3^{\text {a }}$ Edição Revisada e Ampliada. Serviço Geológico do Brasil - CPRM, LABHID. Rio de Janeiro. p 359-379. 2008. 
MEYBECK, M,; KIMSTACH, V.; HELMER, R. Strategies for Water Quality Assessment. In CHAPMAN, D. (ed). Water Quality assessment: a guide to the use of biota, sediments and water in environmental monitoring. Cambridge: UNESCO/WHO/UNEP, 1992. 585p.

MICHELON, C. R. Balanço químico em seis conjuntos solo - saprolito do Rio Grande do Sul. Dissertação de Mestrado. UFSM, Santa Maria, Abril, 2006.

MONTEIRO, C. A. F. Geossistema: A História de uma Procura. Ed. Contexto, São Paulo, 2000.

MORAES, A. J. Manual para a avaliação da qualidade da água. São Carlos: Rima, 2001. $44 \mathrm{p}$.

MORAES, D. S. L.; JORDÃO, B. Q. Degradação de recursos hídricos e seus efeitos sobre a saúde humana. Revista Saúde Pública, USP, 2001.

MOREIRA, R. C. A.; Referência geoquímica regional para interpretação das concentrações de elementos químicos nos sedimentos da bacia do lago Paranoá. Química Nova, v.26, n.0. Brasília, 2003.

MORTATTI J.; PROBST J. L. Silicate rock weathering and atmospheric/soil CO2 uptake in the Amazon basin estimated from river water geochemistry: seasonal and spatial variations. Chemical Geology, 2003, vol. 197, pp. 177- 196.

MORUZZI, R. B. Oxidação e remoção de ferro e manganês em águas para fins de abastecimento público ou industrial - Uma abordagem geral. Revisa de Engenharia e Tecnologia. USP, São Carlos, 2012.

MOURA, L. H. A.; BOAVENTURA, G. R.; PINELLI, M. P. A qualidade de água como indicador de uso e ocupação do solo: Bacia do Gama - Distrito Federal. Química Nova, V.33, N.1, Brasília, 2010.

MÜlLER, G. Schwermetalle in den Sedimenten des Rheins Veranderungen seit. Umschau, v. 79, n. 24, p. 778-783.1979.

MULHOLLAND, D., S.; G. R. \& ARAÚJO, D. F. Geoquímica aplicada a avaliação da qualidade de sistemas aquáticos da Bacia do rio Paracatu. Dissertação de Mestrado $\mathrm{n}^{\circ}$ 256, UnB, Brasília, 2009.

NETO, J. M. M.; MOITA, G. C. Uma introdução à análise exploratória de dados multivariados. Química Nova, pág. 21, vol.4, Departamento de Química, Universidade Federal do Piauí, 1998.

NOVAIS, R. F.; ALVAREZ, V. H. V.; BARROS, N. F.; FONTES, R. L. F.; CANTARUTTI, R. B.; NEVES, J. C. L. Fertilidade do solo, Sociedade Brasileira de Ciência do Solo. Viçosa 2007, $1^{\text {a }}$ ed. 741p. 
OGERA, R. C. Remoção de nitrogênio no esgoto sanitário pelo processo de lodo ativado por batelada. Dissertação (Mestrado em Engenharia Civil) - Faculdade de Engenharia Civil, Universidade Estadual de Campinas, Campinas, 1995.

OliVeirA, H. A.; GUimarães, J. F, XAVIER, S. C. O.; TiMÓteO, A.; A poluição química do Córrego Campo Alegre de Goiás. Monografia de Conclusão do Curso de Geografia, UEG, Pires do Rio, 2001.

OLIVEIRA, C., ARAÚJO, A. P., MAZUR, N. Fundamentos da ciência do solo IA 321. Roteiro de aulas práticas, Instituto de Agronomia, Universidade Federal Rural do Rio de Janeiro, Seropédica, 2002.

OLIVEIRA, R. C. B.; MARINS, R. V.; Dinâmica de metais-traço em solo e ambiente sedimentar estuarino como um fator determinante no Aporte de contaminantes para ambiente aquático. Revista Virtual Química, v.3, n.2, Fortaleza, 2011.

OUYANG, Y.; NKEDI-KIZZA, P. WU, Q. T.; SHINDE, D.; HUANG, C. H.; Water Res. 2006, $40,3800$.

PÁDUA, Z. M. C. Avaliação das emissões de $\mathrm{CO}_{2}$ por veículos de transporte de cargas pelo método Botton-UP em rodovias com pista dupla e simples. Dissertação de Mestrado em desenvolvimento regional, Uniara, Araraquara, 2014.

PALÁCIO, H. A. Q. Índice de qualidade das águas na parte baixa da bacia hidrográfica do rio Trussu, Ceará. Dissertação (Mestrado em Irrigação e Drenagem) - Universidade Federal do Ceará, Fortaleza, 2004.

PARRON, L. M. MUNIZ, D. H. F.; PEREIRA, C. M. Manual de procedimentos de amostragem e análise físico-química de água. Embrapa florestas, Colombo, 2011.

PAZ, V. S.; TEODORO, R. F.; MENDONÇA, F. C.; Recursos Hídricos, agricultura irrigada e meio ambiente. Revista Brasileira de Engenharia Agrícola e Ambiental, Campinas Grande, v.4, n.3, p.465-473, 2000.

PENIDO, J. S. Estudos limnológicos e ecotoxicológicos com amostras de água e sedimento do ribeirão Limeira-Piquete/Lorena-SP. Universidade de São Paulo, Escola de Engenharia de Lorena, Lorena, 2010.

PEREIRA L. F., DARDENNE M. A., ROSIÈRE C. A., PEDROSA-SOARES A. C., Evolução Geológica dos grupos Canastra e Ibiá na região entre Coromandel e Guarda-Mor. Geonomos,MG; 1992.

PEREIRA, J. C., SILVA, A. K., JÚNIOR, H. A. N. Distribuição, fracionamento e mobilidade de elementos trações em sedimentos superficiais. Química Nova, v. 30, n. 5, pág 1249-1255, 2007. 
PERES, V. N., COELHO, L. M., FERREIRA. I. M.; Avaliação da qualidade da água superficial da microbacia do Córrego Fundo- Catalão (GO). Revista de Ciências Ambientais, Canoas, v.3, n.2, p. 67 a 85, 2009.

PIMENTA, S. M.; LIMA, C. V.; RIBEIRO, T. G. Avaliação Físico-Química da qualidade da Água, Relação com o uso do Solo na Bacia do Ribeirão Santo Antônio. Revista Processos Químicos, Jun, 2009.

PIPER, A. M. 1944. A graphif procedure in the geochemical interpretation of water analyses. Transactions American Geophysical Union 25:914-923.

POMPÊO, M., PADIAL, P. R., MARIANI, C. F., SILVA, S. C., CARLOS, V. M., SILVA, D. C. V. R., PAIVA, T. C. B., BRANDIMARTE, A. L. Biodisponibilidade de metais no sedimento de um reservatório tropical urbano (reservatório Guarapiranga - São Paulo (SP), Brasil): há toxicidade potencial e heterogeneidade espacial. Geochimica Brasiliensis 27(2): 104-119 2013.

PÓRRECA, L. M.; ABC do Meio Ambiente-Água. Instituto Brasileiro do Meio Ambiente e dos Recursos Naturais e Renováveis, Ed. Ibama, Brasília, 1998.

POZZA, A. A. A.; CURI, N., COSTA, E. T. S.; GUILHERME, L. R. G.; MARQUES, J. J. G. S. M.; MOTTA, P. E. F. Retenção e desorção competitivas de ânions inorgânicos em gibbsita natural de solo. Pesquisa agropecuária Brasileira, v. 42, n.11, p.1627-1633, Brasília, 2007.

PRESS, F.; SIEVER, R.; GROTZINGER, J.; JORDAN, T. H. Para Entender a Terra. 4a Edição. Trad. MENEGAT, R.; FERNANDES, P. C. D.; FERNANDES, L. A. D.; PORCHER, C.C. Porto Alegre, Bookman. 2006. 656p.

PROGRAMA DAS NAÇÕES UNIDAS PARA O DESENVOLVIMENTO- PNUD. A água para lá da escassez: poder, pobreza e a crise mundial da água. Relatório do desenvolvimento humano. New York, 2006.

RAMALHO, J. F. G. P. et al. Contaminação da microbacia de Caetés com metais pesados pelo uso de agroquímicos. Brasília: Pesquisa Agropecuária Brasileira. Brasília, v. 35. n.7.p. 1289-1303, 2000.

RANGEL, C. F.; Monitoramento de agrotóxicos em Águas Brutas e Tratadas destinadas ao consumo humano, utilizando Método Multi - Resíduo por EFS/CG-EM. Dissertação de mestrado, Rio de Janeiro, 2008.

RANZINI, M.; RIGHETTO, A. M.; LIMA, W. P.; GUANDIQUE, M. E. G.; ARVOCA, F. C, S.; CICCO, V. Processos hidrológicos de uma microbacia com Mata Atlântica, na região da Serra do Mar, SP. Scientia Forestalis, nº 66, p.108-119, dez, 2004.

REIS, J. A. T., MENDONÇA, A. S. F. A influência dos valores de pH e temperatura sobre a toxicidade da amônia e sua importância na definição de padrões ambientais para 
corpos d' água. $20^{\circ}$ Congresso Brasileiro de Engenharia Sanitária e Ambiental. Vila Velha, 1997.

REIMANN, C., CARITAT, P. Distinguishing between natural and anthropogenic sources for elements in the environment: regional geochemical surveys versus enrichment factors. Scient oh the Total Enviromment 337, Australia, 2004.

RESENDE, A. V. Agricultura e Qualidade da Água: Contaminação da Água por Nitrato. Empresa Brasileira de Pesquisa Agropecuária, Ministério da Agricultura, Pecuária e Abastecimento, Dezembro, Planaltina, 2002.

RICHTER, C. A. Água- métodos e tecnologia de tratamento. São Paulo-SP: Blucher, 2009. 340p., river water by exploratory data analysis. Water Research, v.32, n.12, p.3581-3592, 1998.

ROCHA, A. L. A.; PARON, L. M.; CRUZ, C. J. D.; Monitoramento da qualidade de água de nascentes da Bacia Hidrográfica do Rio Preto, sub bacia do médio Rio São Francisco. Lavras, Ed. Embrapa, 2008.

RODRIGUES, A. S. L.; Valores de background geoquímico e suas implicações em estudos ambientais. REM, v. 62, nº 2, pág. 155-165, Ouro Preto, 2009.

RODRIGUES, T. E. Solos da Amazônia. In: ALVAREZ, V. H. V.; 40 KER, J. C. FONTES, L. E. F.; FONTES, M. P. F. eds. Os solos os grandes domínios morfoclimáticos do Brasil e o desenvolvimento sustentado. Viçosa, SBCS/UFV, 1996. p. 16-60.

ROMERO, R. R. Resposta fisiológica de plantas de Eucalyptus grandis à adubação com potássio ou sódio. Dissertação Mestrado, Escola Superior de Agricultura "Luiz de Queiroz”, Universidade de São Paulo, Piracicaba, 2008.

SAMPAIO, A. C. S. Metais pesados na água e de sedimentos dos rios da bacia do Alto Paraguai. Programa de pós-graduação em tecnologias ambientais, Universidade Federal de Mato Grosso do Sul, Campo Grande, 2003.

SANCHES, S. M.; SILVA, C. T. P; Pesticidas e seus respectivos riscos associados à contaminação da água. Curitiba, v. 13, jan./dez. 2003.

SANEAGO - SANEAMENTO DE GOIÁS S/A. Saneamento Básico. Disponível em: 〈http://www.SANEAGO.com.br/novasan/?id=esgoto6\&tit=esgoto>. Acesso em nov. 2008.

SANTOS, A. Distribuição dos metais no reservatório de captação de água superficial Anhumas- Américo Brasiliense. Dissertação de Mestrado. IQSC, USP, São Carlos, 1999.

SANTOS, A. C. 1997. Noções de hidroquímica. In: Feitosa F. A. C. E Manoel Filho J. Hidrogeologia, Conceitos e Aplicações. Fortaleza, CPRM/LABHID/UFPE, 81-108. 
SANTOS, G. V. S.; DIAS, H. C. T. D.; SILVA, A. S.; MACEDO, M. N. C.; Análise hidrológica e socioambiental da bacia hidrológica do córrego Romão dos reis, Viçosa-MG. Revista Árvore, v.31, n.5, Viçosa-MG 2007.

SARDINHA, D. S., Avaliação da taxa de intemperismo químico na Bacia do Rio Jaú (SP). Instituto de Geociências e Ciências Exatas, Universidade Estadual Paulista, Rio Claro, 2011.

SCHEFFER, E. W., SODRÉ, F. F., GRASSI, M. T. Fatores que governam a especiação do cobre em ambientes aquáticos urbanos: evidências da contribuição de sulfetos solúveis. Química Nova, Vol. 30, No. 2, 332-338, 2007.

SEGANFREDO, M. A., SOARES, I. J., KLEIN, C. S. Qualidade da Água de Rios numa Região de Pecuária Intensiva de SC. Ministério da Agricultura, Pecuária e Abastecimento, Relatório técnico, Concórdia,2003.

SEPLAN, Goiás em Dados 2011/ Secretaria de Estado de Gestão e Planejamento; Superintendência de Estatísticas. Pesquisa e Informações Socioeconômicas- Goiânia, 2011.

SERRAT, B. M., LIMA, M. R. L., GARCIAS, C. E., FANTIN, E. R., CARNIERI, I, M, R. S. A., PINTO, L, S. Conhecendo o solo. Projeto de extensão de solo e eng. Agrícola, Universidade Federal do Paraná, Curitiba, novembro, 2002.

SFREDO, G. J.; OLIVEIRA, M. C. N. Soja Molibdênio e Cobalto. Embrapa Soja, Londrina, Pr, 2010.

SHUQAIR, S. M. S. Estudo da contaminação do solo e água subterrânea por elementos tóxicos originados dos rejeitos das minas de carvão de figueira no estado do Paraná. Autarquia Associada à Universidade de São Paulo, Ipen, São Paulo, 2002.

SIEG. 2013. Sistema Estadual de Geoinformação. http://www.sieg.go.gov.br, Goiania, GO.

SILVA C. H., SIMÕES L. S. A, DAMÁZIO W. L., FERREIRA S.N., LUVIZOTTO G. L., O Grupo Canastra em sua área-tipo, região de Tapira, sudoeste do estado de Minas Gerais; Geol. USP, Sér. Cient. Vol.12 nº 2 São Paulo agosto, 2012.

SILVA, M. C. Diagnóstico dos recursos hídricos na microbacia do córrego três Barras, município de Marinópolis, SP. Universidade Estadual Paulista, 2010.

SILVA, A. M.; ALVES, S. M.; Análises dos registros de intoxicação por agrotóxicos em Goiás, no período de 2001 a 2004. Revista Eletrônica de Fármacia, v. 4. Anápolis, 2007.

SILVA, M. L. S. Avaliação do comportamento de elementos traço essenciais e não essenciais em solo contaminado sob cultivo de plantas. Tese de doutorado, USP, Piracicaba, 2006. 
SILVEIRA, T.; Análise físico-química da água da Bacia do Rio Cabelo- João Pessoa- PB. II Congresso de Pesquisa e Inovação da Rede Norte Nordeste de Educação Tecnológica, João Pessoa, 2007.

SINGH, K. P.; MALIK, A.; MOHAN, D.; SINHA, S.; Water Res. 2004, 38, 3980

SOARES, M. C.C.; MIZUSAKI, A. P.; GUERRA, T.; VIGNOL, M. L.; Análise Geoquímica dos Sedimentos de Fundo do Arroio do Salso, Porto Alegre-RS-Brasil. Instituto de Geociências, Universidade Federal do Rio Grande do Sul, Porto Alegre, Rs, Brasil, 2004.

SOUZA, R. B. 1-UERN; MARTINS, D. F. F. Efeito da sazonalidade na alcalinidade da água do rio apodi/mossoró no perímetro urbano da cidade de Mossoró. Química Ambiental, XLVI Congresso Brasileiro de Química, Salvador, 2005.

STRANDBERG, C. H. 1971. Water pollution. In: SMITH,G.H. (Ed). Conservation of natural resources. $4^{\circ}$ Edição. Willey. New York. 189-219 pp.

TERNUS, R. Z. Caracterização Limnológica de afluentes da Bacia do Alto Rio UruguaiSC. Dissertação de Mestrado, Programa de Pós- Graduação em Ciências Ambientais, Universidade Comunitária Regional de Chapecó, Chapecó, Agosto, 2007.

TOLEDO, L., G.; FERREIRA, C. J. A. Impactos das atividades agrícolas na qualidade da água. Revista Plantio Direto, Passo Fundo, n. 58, p. 21-27, 2000.

TOLEDO, L. G.; NICOLELLA, G.; Índice de qualidade de água em microbacia sob uso agrícola e urbano. Scientia Agrícola, v.59, n.1, p181-186, Jaguariúna, 2002.

TUCCI, C. E. M. Controle de Enchentes. In: TUCCI, C. E. M. Hidrologia: ciência e aplicação. Porto Alegre, RS: ABRH - Edusp, 1993. cap. 4.

TUCCI, C. E. M. Água no meio urbano, Universidade Federal do Rio Grande do Sul. Capítulo 14 do Livro Água Doce, Dezembro, 1997.

TUCCI, C. E. M. Água no meio urbano. In REBOUÇAS, A; BRAGA, B.; TUNDISI, L. G. Uso e conservação. 2. Ed. São Paulo: Academia Brasileira de Ciências, Instituto de Estudos Avançados, USP, 2002. Pág.473 - 506.

UNESCO/WHO/UNEP. Water Quality Assessments. London: Chapman \& Hall, 1992. Cap 3: TheSelection of Water Quality Variables: p.51-119.

VARELlA, C. A. A. Análise de Componentes Principais. Pós-graduação em agronomia. UFRRJ, Seropédia, 2008.

VASCONCELOS, M. G. Avaliação integrada da qualidade da água do Rio UberabinhaMG com base na caracterização química dos sedimentos e de espécimes da ictiofauna. Programa Multi-Institucional de doutorado em química, UFU,Uberlândia, 2012. 
VEIGA, J. B., CARDOSO, E. C. Criação de Gado Leiteiro na Zona Bragantina, Embrapa Amazônia Oriental, Dezembro, 2005. Disponível em < http://sistemasdeproducao.cnptia.embrapa.br/FontesHTML/Leite/GadoLeiteiroZonaBraga ntina/paginas/smineral.htm $>$ Acesso em janeiro de 2015.

VEIGA, M. M.; SILVA, D. M.; FARIA, M. V. C.; Análise da contaminação dos sistemas hídricos por agrotóxicos numa pequena comunidade rural do Sudeste do Brasil. Cad. Sáude Pública, Rio de Janeiro, 2006.

VON SPERLING, M. Introdução à qualidade das águas e do tratamento de esgoto. 2 ed., 1996.

WEDEPOHL, K. H. (Ed). 1978. Handbook of Geochemistry. Springer Verlag, Berlin, Heidelberg. 1: 248.

WEDEPOHL, K. H. The composition of the Continental Crust Geochimica et Cosmochimica, Acta, 59 (7): 1217-1232, 1995.

WWF, Trabalho de Campo da Aget 0103, Relatório, 2004. 
ANEXOS 
Anexo 1: Resultados dos parâmetros físico-químicos nas amostras de água do período seco

\begin{tabular}{|c|c|c|c|c|c|c|c|c|c|c|c|c|c|c|c|c|c|}
\hline & $\mathbf{P h}$ & C.E & $\mathbf{C a}$ & $\mathbf{M g}$ & $\mathrm{Na}$ & K & $\mathbf{N H}_{3}$ & $\mathbf{F}^{-}$ & $\mathrm{Cl}^{-}$ & $\mathrm{NO}_{3}{ }^{-}$ & $\mathrm{PO}_{4}{ }^{3-}$ & $\mathrm{SO}_{4}{ }^{2-}$ & $\mathrm{HCO}_{3}^{-}$ & $\mathbf{F e}$ & $\mathbf{S i}$ & Al & $\mathrm{CO}_{2}$ \\
\hline P1 & 5,12 & 5,47 & 0,6 & 0,2 & 0,2 & 0,1 & $<\mathrm{LQ}$ & $<\mathrm{LQ}$ & 0,3 & $\begin{array}{l}<\mathrm{LQ} \\
\end{array}$ & $<\mathrm{LQ}$ & $<\mathrm{LQ}$ & 3,1 & $\begin{array}{l}<\mathrm{LQ} \\
\end{array}$ & 1,8 & $<\mathrm{LQ}$ & 0,352 \\
\hline $\mathbf{P 2}$ & 5,02 & 7,07 & 0,5 & 0,2 & 0,3 & 0,1 & $<\mathrm{LQ}$ & $<L Q$ & 0,4 & $<\mathrm{LQ}$ & $<\mathrm{LQ}$ & $<\mathrm{LQ}$ & 3,7 & 0,6 & 1,5 & $<\mathrm{LQ}$ & 6,33 \\
\hline P3 & 5,80 & 22,50 & 1,9 & 0,2 & 2,0 & 0,3 & $<\mathrm{LQ}$ & $<L Q$ & 1,6 & 2,0 & $<\mathrm{LQ}$ & 0,5 & 8,1 & 0,5 & 1,9 & $<\mathrm{LQ}$ & 0 \\
\hline P4 & 5,86 & 18,14 & 1,7 & 0,2 & 1,2 & 0,7 & 0,9 & $\begin{array}{l}<\mathrm{LQ} \\
\end{array}$ & 1,5 & 0,6 & $<\mathrm{LQ}$ & 0,7 & 7,0 & $\begin{array}{l}<Q \\
\end{array}$ & 2,0 & $<\mathrm{LQ}$ & 5,28 \\
\hline P5 & 5,68 & 9,99 & 0,9 & 0,2 & 0,4 & 0,2 & 0,1 & $<L Q$ & 0,6 & $<\mathrm{LQ}$ & $<\mathrm{LQ}$ & $<\mathrm{LQ}$ & 5,3 & 0,4 & 1,7 & $<\mathrm{LQ}$ & 0 \\
\hline P6 & 5,52 & 4,39 & 0,4 & $\begin{array}{l}<\mathrm{LQ} \\
\end{array}$ & 0,3 & 0,1 & $\begin{array}{l}<\mathrm{LQ} \\
\end{array}$ & $\begin{array}{l}<\mathrm{LQ} \\
\end{array}$ & 0,3 & $\begin{array}{l}<\mathrm{LQ} \\
\end{array}$ & $\begin{array}{l}<\mathrm{LQ} \\
\end{array}$ & $\begin{array}{l}<\mathrm{LQ} \\
\end{array}$ & 2,5 & 0,2 & 1,4 & $<\mathrm{LQ}$ & 0 \\
\hline P7 & 5,89 & 14,61 & 1,0 & 0,2 & 1,4 & 0,3 & $<\mathrm{LQ}$ & $\begin{array}{l}<Q \\
\end{array}$ & 1,2 & 0,9 & $\begin{array}{l}\mathrm{LQ} \\
\end{array}$ & $<\mathrm{LQ}$ & 6,1 & $\begin{array}{l}<Q \\
\end{array}$ & 2,3 & $<\mathrm{LQ}$ & 0 \\
\hline P8 & 6,12 & 29,50 & 1,8 & 0,4 & 3,4 & 0,5 & $<\mathrm{LQ}$ & $<\mathrm{LQ}$ & 2,5 & 2,7 & $<\mathrm{LQ}$ & $<\mathrm{LQ}$ & 10,5 & $<\mathrm{LQ}$ & 2,6 & $<\mathrm{LQ}$ & 0 \\
\hline P9 & 5,74 & 5,78 & 0,4 & 0,2 & 0,4 & 0,1 & $<L Q$ & $<$ <Q & 0,3 & 0,4 & $<\mathrm{LQ}$ & $<\mathrm{LQ}$ & 2,8 & $<L Q$ & 2,3 & $<\mathrm{LQ}$ & 0 \\
\hline P10 & 5,52 & 5,46 & 0,3 & $<L Q$ & 0,4 & 0,1 & $<\mathrm{LQ}$ & $<\mathrm{LQ}$ & 0,4 & $<\mathrm{LQ}$ & $<\mathrm{LQ}$ & $<\mathrm{LQ}$ & 2,9 & $<\mathrm{LQ}$ & 2,0 & $<\mathrm{LQ}$ & 0 \\
\hline P11 & 5,73 & 5,20 & 0,4 & $<L Q$ & 0,4 & 0,1 & $<\mathrm{LQ}$ & $<L Q$ & 0,4 & $<\mathrm{LQ}$ & $<\mathrm{LQ}$ & $<\mathrm{LQ}$ & 3,0 & $<\mathrm{LQ}$ & 2,1 & $<\mathrm{LQ}$ & 0 \\
\hline P12 & 5,67 & 5,61 & 0,3 & 0,2 & 0,4 & $<\mathrm{LQ}$ & $<\mathrm{LQ}$ & $\begin{array}{l}<\mathrm{LQ} \\
\end{array}$ & 0,4 & $<\mathrm{LQ}$ & $<\mathrm{LQ}$ & $<\mathrm{LQ}$ & 2,6 & $<\mathrm{LQ}$ & 2,3 & $<\mathrm{LQ}$ & 0 \\
\hline P13 & 5,61 & 5,27 & 0,4 & $<\mathrm{LQ}$ & 0,4 & 0,1 & $\begin{array}{l}<\mathrm{LQ} \\
\end{array}$ & $\begin{array}{l}<\mathrm{LQ} \\
\end{array}$ & 0,4 & $<\mathrm{LQ}$ & $<\mathrm{LQ}$ & $<\mathrm{LQ}$ & 2,8 & $<\mathrm{LQ}$ & 2,2 & $<\mathrm{LQ}$ & 0 \\
\hline P14 & 5,59 & 5,84 & 0,5 & 0,2 & 0,4 & 0,1 & $<\mathrm{LQ}$ & $\begin{array}{l}<\mathrm{LQ} \\
\end{array}$ & 0,4 & $<\mathrm{LQ}$ & $<\mathrm{LQ}$ & $<\mathrm{LQ}$ & 2,6 & $<\mathrm{LQ}$ & 2,3 & $<\mathrm{LQ}$ & 0 \\
\hline $\mathbf{P 1 5}$ & 6,60 & 15,93 & 2,5 & 0,2 & 0,5 & 0,1 & $<\mathrm{LQ}$ & $<\mathrm{LQ}$ & 0,4 & $<\mathrm{LQ}$ & $<\mathrm{LQ}$ & 0,9 & 7,5 & $\begin{array}{l}\mathrm{LQ} \\
\end{array}$ & 2,4 & $<\mathrm{LQ}$ & 0 \\
\hline P16 & 6,00 & 12,40 & 1,9 & 0,2 & 0,5 & 0,1 & $<\mathrm{LQ}$ & $\begin{array}{l}<\mathrm{LQ} \\
\end{array}$ & 0,7 & 0,2 & $<\mathrm{LQ}$ & 0,6 & 5,4 & $<\mathrm{LQ}$ & 2,5 & $<\mathrm{LQ}$ & 0 \\
\hline P17 & 5,80 & 11,50 & 1,7 & 0,1 & 0,0 & 0,0 & $<\mathrm{LQ}$ & 0,0 & 0,9 & 0,0 & 0,0 & 0,0 & 4,7 & LQ & 2,4 & $<\mathrm{LQ}$ & 0 \\
\hline
\end{tabular}

LQ: Limite de Quantificação

Anexo 2: Resultados dos parâmetros físico-químicos nas amostras de água do período chuvoso

\begin{tabular}{|c|c|c|c|c|c|c|c|c|c|c|c|c|c|c|c|c|}
\hline & $\mathbf{p H}$ & $\mathbf{C . E}$ & $\mathbf{C a}$ & $\mathbf{M g}$ & $\mathbf{N a}$ & $\mathbf{K}$ & $\mathbf{F}^{-}$ & $\mathbf{C l}^{-}$ & $\mathbf{N O}^{-}$ & $\mathbf{P O}_{4}{ }^{3-}$ & $\mathbf{S O}_{4}{ }^{2-}$ & $\mathbf{H C O}_{3}{ }^{-}$ & $\mathbf{F e}$ & $\mathbf{S i}$ & $\mathbf{A l}$ & $\mathbf{C O}_{2}$ \\
\hline P1 & 5,66 & 7,08 & 0,90 & $<\mathrm{LQ}$ & 0,40 & 0,12 & $<\mathrm{LQ}$ & 0,23 & 0,35 & $<\mathrm{LQ}$ & $<\mathrm{LQ}$ & 3,62 & $<\mathrm{LQ}$ & 2.3 & $<\mathrm{LQ}$ & 1,41 \\
\hline P2 & 5,64 & 9,49 & 1,30 & $<\mathrm{LQ}$ & 0,33 & 0,10 & $<\mathrm{LQ}$ & 0,39 & 0,33 & $<\mathrm{LQ}$ & $<\mathrm{LQ}$ & 4,80 & 1,24 & 1,8 & $<\mathrm{LQ}$ & 2,11 \\
\hline P3 & 6,42 & 44,7 & 6,18 & 0,35 & 2,05 & 0,40 & $<\mathrm{LQ}$ & 2,26 & 3,06 & $<\mathrm{LQ}$ & 0,38 & 19,44 & 0,35 & 2,2 & $<\mathrm{LQ}$ & 2,46 \\
\hline P4 & 6,38 & 15,19 & 1,16 & 0,24 & 1,30 & 0,80 & $<\mathrm{LQ}$ & 0,39 & 0,56 & $<\mathrm{LQ}$ & 0,42 & 7,28 & 0,35 & 1,7 & $<\mathrm{LQ}$ & 1,76 \\
\hline P5 & 6,56 & 11,97 & 1,29 & 0,22 & 0,50 & 0,25 & $<\mathrm{LQ}$ & 0,25 & 0,34 & $<\mathrm{LQ}$ & 0,26 & 5,39 & $<\mathrm{LQ}$ & 1,5 & $<\mathrm{LQ}$ & 3,17 \\
\hline P6 & 5,63 & 6,42 & 0,45 & 0,13 & 0,60 & 0,10 & $<\mathrm{LQ}$ & 0,38 & 0,37 & $<\mathrm{LQ}$ & $<\mathrm{LQ}$ & 2,89 & $<\mathrm{LQ}$ & 1,7 & $<\mathrm{LQ}$ & 2,82 \\
\hline P7 & 6,56 & 27,4 & 1,76 & 0,29 & 3,50 & 0,30 & $<\mathrm{LQ}$ & 1,15 & 2,68 & $<\mathrm{LQ}$ & 0,32 & 11,37 & $<\mathrm{LQ}$ & 2,3 & $<\mathrm{LQ}$ & 2,11 \\
\hline P8 & 6,58 & 56,4 & 8,38 & 0,44 & 2,00 & 0,55 & $<\mathrm{LQ}$ & 2,7 & 4,24 & $<\mathrm{LQ}$ & 0,45 & 24,88 & $<\mathrm{LQ}$ & 2,3 & $<\mathrm{LQ}$ & 2,46 \\
\hline P9 & 6,01 & 10,05 & 1,05 & 0,21 & 0,56 & 0,10 & $<\mathrm{LQ}$ & 0,51 & 0,55 & $<\mathrm{LQ}$ & 0,32 & 4,53 & $<\mathrm{LQ}$ & 2,1 & $<\mathrm{LQ}$ & 2,46 \\
\hline P10 & 5,83 & 8,24 & 0,95 & 0,14 & 0,47 & 0,10 & $<\mathrm{LQ}$ & 0,41 & 0,38 & $<\mathrm{LQ}$ & $<\mathrm{LQ}$ & 3,58 & $<\mathrm{LQ}$ & 2,1 & $<\mathrm{LQ}$ & 1,76 \\
\hline P11 & 5,90 & 7,88 & 0,70 & 0,15 & 0,45 & 0,08 & $<\mathrm{LQ}$ & 0,41 & 0,31 & $<\mathrm{LQ}$ & 0,24 & 3,18 & $<\mathrm{LQ}$ & 2,1 & $<\mathrm{LQ}$ & 2,11 \\
\hline P12 & 5,84 & 8,18 & 0,81 & 0,15 & 0,50 & 0,06 & $<\mathrm{LQ}$ & 0,35 & 0,32 & $<\mathrm{LQ}$ & $<\mathrm{LQ}$ & 4,10 & $<\mathrm{LQ}$ & 2,1 & $<\mathrm{LQ}$ & 1,76 \\
\hline P13 & 5,63 & 2,36 & 0,13 & 0,05 & 0,42 & 0,08 & 0 & $<\mathrm{LQ}$ & 0,30 & $<\mathrm{LQ}$ & $<\mathrm{LQ}$ & 1,01 & $<\mathrm{LQ}$ & 1,5 & $<\mathrm{LQ}$ & 1,76 \\
\hline P14 & 6,60 & 30,1 & 4,75 & 0,15 & 1,08 & 0,08 & 0,41 & $<\mathrm{LQ}$ & 0,36 & $<\mathrm{LQ}$ & 0,68 & 14,79 & $<\mathrm{LQ}$ & 2,0 & $<\mathrm{LQ}$ & 1,41 \\
\hline P15 & 6,57 & 27 & 4,29 & 0,16 & 1,01 & 0,08 & $<\mathrm{LQ}$ & 0,43 & 0,33 & $<\mathrm{LQ}$ & 0,6 & 14,34 & $<\mathrm{LQ}$ & 2,0 & $<\mathrm{LQ}$ & 3,17 \\
\hline P16 & 6,64 & 30 & 5,02 & 0,13 & 0,80 & 0,10 & 0,52 & 1,12 & 0,34 & $<\mathrm{LQ}$ & 0,75 & 13,36 & $<\mathrm{LQ}$ & 2,1 & $<\mathrm{LQ}$ & 2,82 \\
\hline P17 & 6,43 & 20,9 & 1,72 & 0,29 & $<\mathrm{LQ}$ & $<\mathrm{LQ}$ & $<\mathrm{LQ}$ & 1,03 & 0,86 & $<\mathrm{LQ}$ & 0 & 9,59 & 0,189 & 2,05 & 0,02 & 2,82 \\
\hline
\end{tabular}

LQ: Limite de Quantificação. 
Anexo 3: Resultados da Análise de Sedimento de Fundo (Óxidos) e Sólidos Voláteis (\%)

\begin{tabular}{|c|c|c|c|c|c|c|c|c|c|}
\hline & $\mathrm{SiO}_{2}$ & $\mathbf{A l}_{2} \mathbf{O}_{3}$ & $\mathbf{F e}_{2} \mathbf{O}_{3}$ & $\mathbf{C a O}$ & $\mathbf{M g O}$ & $\mathbf{T i O}_{2}$ & $\mathbf{N a}_{2} \mathbf{O}$ & $\mathbf{K}_{2} \mathbf{O}$ & $\mathbf{P F}$ \\
\hline P1 & 21,7 & 32,8 & 15,7 & 0,5 & 0,1 & 2,2 & 0,566 & 0,434 & 25,97 \\
\hline P2 & 19,5 & 35,5 & 15,3 & 0,8 & 0,0 & 2,3 & 0,9 & 0,2 & 25,54 \\
\hline P3 & 37,5 & 19,7 & 10,6 & 0,4 & 0,0 & 0,6 & 0,3 & 0,3 & 30,63 \\
\hline P4 & 44,4 & 22,6 & 13,8 & 0,7 & 0,3 & 1,8 & 0,9 & 0,9 & 14,56 \\
\hline P5 & 34,4 & 25,2 & 16,9 & 0,4 & 0,2 & 1,8 & 0,5 & 0,8 & 19,83 \\
\hline P6 & 45,6 & 15,6 & 20,6 & 0,4 & 0,2 & 1,6 & 0,6 & 1,1 & 14,32 \\
\hline P7 & 40,5 & 21,0 & 13,7 & 0,4 & 0,1 & 1,5 & 0,6 & 0,5 & 21,77 \\
\hline P8 & 36,5 & 24,0 & 15,1 & 1,4 & 0,4 & 1,7 & 1,0 & 0,6 & 19,30 \\
\hline P9 & 38,0 & 22,1 & 5,8 & 0,5 & 0,1 & 1,6 & 0,7 & 0,2 & 30,93 \\
\hline P10 & 32,4 & 24,6 & 15,5 & 0,3 & 0,1 & 1,5 & 0,7 & 0,6 & 24,28 \\
\hline P11 & 37,4 & 18,5 & 11,1 & 0,9 & 0,0 & 1,4 & 0,7 & 0,3 & 29,70 \\
\hline P12 & 30,5 & 21,8 & 16,0 & 0,6 & 0,2 & 2,4 & 0,8 & 0,7 & 27,00 \\
\hline P13 & 38,7 & 24,8 & 11,9 & 0,7 & 0,2 & 3,1 & 0,9 & 0,9 & 18,78 \\
\hline P14 & 38,4 & 24,0 & 4,9 & 0,7 & 0,2 & 1,7 & 0,6 & 0,6 & 28,85 \\
\hline
\end{tabular}

Anexo 4:Resultados da Análise de Sedimento de Fundo dos Elementos- Traço (mg/L)

\begin{tabular}{|c|c|c|c|c|c|c|c|c|c|c|c|c|c|c|c|}
\hline & Sr & Ba & Y & La & $\mathbf{V}$ & $\mathbf{C r}$ & $\mathbf{M o}$ & $\mathbf{M n}$ & $\mathbf{C o}$ & $\mathbf{N i}$ & $\mathbf{C u}$ & Zn & Cd & P & Pb \\
\hline P1 & 0,9 & 13,1 & 2,6 & 3,8 & 334,3 & 60,3 & 31,2 & 38,7 & 2,8 & 5,9 & 46 & 34,4 & 8,9 & 568,9 & 109,4 \\
\hline P2 & 2 & 16,6 & 1,1 & 2,1 & 375,7 & 43,4 & 39,9 & 44,9 & 2,4 & 5,2 & 38,1 & 24,7 & 11,3 & 570 & 133,6 \\
\hline P3 & 3,4 & 39,4 & 3,1 & 5 & 249,6 & 60,4 & 23,6 & 116,1 & 3,6 & 8,1 & 82,7 & 75,9 & 6,1 & 809,5 & 133 \\
\hline P4 & 5,9 & 61,9 & 2,3 & 4,8 & 246,6 & 61,7 & 21,9 & 140,2 & 4,5 & 9,2 & 140 & 102,8 & 6,4 & 1052,1 & 125,7 \\
\hline P5 & 0 & 28,1 & 2,3 & 3,8 & 228,1 & 58,7 & 23,2 & 73,6 & 3,4 & 7,5 & 53,8 & 63,3 & 6,8 & 974,3 & 123,4 \\
\hline P6 & 1,3 & 56,9 & 1,7 & 4,2 & 135,7 & 65,5 & 14 & 453,1 & 12,4 & 9,4 & 144,5 & 77 & 4,7 & 621 & 96,7 \\
\hline P7 & 1,2 & 35,9 & 4,5 & 6 & 186,3 & 49,4 & 19,3 & 218,1 & 6,3 & 8,4 & 86,4 & 80,4 & 5,5 & 932,6 & 85 \\
\hline P8 & 1,8 & 19,8 & 2,7 & 3,3 & 116,7 & 35,1 & 11,2 & 124 & 2,3 & 3,6 & 69,3 & 73,3 & 1,7 & 621,2 & 101,2 \\
\hline P9 & 2,2 & 31,4 & 6,8 & 10,1 & 207,4 & 46,1 & 19,9 & 56,1 & 1,8 & 5,7 & 42,5 & 31,5 & 3,4 & 817,3 & 96,1 \\
\hline P10 & 19,5 & 33,8 & 7,8 & 9 & 167,8 & 44,2 & 18,3 & 111,9 & 4,9 & 6,7 & 53,1 & 56,8 & 4,6 & 800,8 & 144,4 \\
\hline P11 & $-1,3$ & 31,2 & 11 & 11,9 & 209,7 & 56,3 & 22,3 & 41,7 & 3,9 & 8,6 & 78,9 & 78,7 & 7,1 & 889,9 & 206,5 \\
\hline P12 & 2,1 & 31 & 4,5 & 6,7 & 215,8 & 48 & 22,7 & 315,8 & 8 & 8,3 & 75,6 & 80,3 & 6,6 & 972,7 & 136,2 \\
\hline P13 & 7,2 & 29,7 & 2,5 & 4,8 & 228,4 & 50,9 & 22,1 & 125,9 & 3,5 & 6,6 & 89,7 & 72,6 & 4,9 & 926,6 & 117,2 \\
\hline P14 & 2,9 & 28,8 & 3 & 5,3 & 196,5 & 53,3 & 19,7 & 94,9 & 2,6 & 6,1 & 80,6 & 58,7 & 4,9 & 874,4 & 111,4 \\
\hline
\end{tabular}


Anexo 5: $I_{\text {geo }}$ Calculado para Óxidos $(m g / L)$.

\begin{tabular}{|c|c|c|c|c|c|c|c|c|}
\hline & $\mathrm{SiO}_{2}$ & $\mathbf{A l}_{2} \mathbf{O}_{3}$ & $\mathrm{Fe}_{2} \mathrm{O}_{3}$ & $\mathrm{CaO}$ & MgO & $\mathbf{T i O}_{2}$ & $\mathrm{Na}_{2} \mathrm{O}$ & $\mathrm{K}_{2} \mathrm{O}$ \\
\hline P1 & $-0,58$ & $-0,58$ & $-0,58$ & 0,58 & $-0,58$ & 0,58 & $-0,58$ & $-0,58$ \\
\hline $\mathbf{P 2}$ & $-0,74$ & $-0,47$ & $-0,63$ & 0,29 & $-4,34$ & $\begin{array}{c}- \\
0,52\end{array}$ & 0,02 & $-1,67$ \\
\hline P3 & 0,20 & $-1,33$ & $-1,16$ & $\begin{array}{c}- \\
0,68 \\
\end{array}$ & $\begin{array}{c}- \\
3,567 \\
\end{array}$ & $\begin{array}{c}- \\
2,52 \\
\end{array}$ & $-1,39$ & $-1,00$ \\
\hline P4 & 0,45 & $-1,12$ & $-0,77$ & 0,07 & 0,50 & $\begin{array}{c}- \\
0,89\end{array}$ & 0,13 & 0,42 \\
\hline P5 & 0,08 & $-0,96$ & $-0,48$ & $\begin{array}{c}- \\
0,82\end{array}$ & $-0,24$ & $\begin{array}{c}- \\
0,88\end{array}$ & $-0,69$ & 0,25 \\
\hline P6 & 0,49 & $-1,66$ & $-0,20$ & $\begin{array}{c}- \\
0,68 \\
\end{array}$ & 0,09 & $\begin{array}{c}- \\
1,05 \\
\end{array}$ & $-0,52$ & 0,70 \\
\hline P7 & 0,32 & $-1,23$ & $-0,79$ & $\begin{array}{c}- \\
0,65\end{array}$ & $-1,53$ & $\begin{array}{c}- \\
1,10\end{array}$ & $-0,45$ & $-0,47$ \\
\hline P8 & 0,17 & $-1,03$ & $-0,65$ & 1,04 & 0,99 & $\begin{array}{c}- \\
0,90\end{array}$ & 0,19 & $-0,14$ \\
\hline P9 & 0,22 & $-1,15$ & $-2,03$ & $\begin{array}{c}- \\
0,36\end{array}$ & $-0,75$ & $\begin{array}{c}- \\
1,04\end{array}$ & $-0,28$ & $-1,43$ \\
\hline P10 & $-0,01$ & $-1,00$ & $-0,61$ & $\begin{array}{c}- \\
1,08\end{array}$ & $-0,43$ & $\begin{array}{c}- \\
1,14\end{array}$ & $-0,22$ & $-0,14$ \\
\hline P11 & 0,20 & $-1,41$ & $-1,09$ & 0,33 & $-2,53$ & $\begin{array}{c}- \\
1,23\end{array}$ & $-0,28$ & $-1,36$ \\
\hline P12 & $-0,09$ & $-1,18$ & $-0,56$ & $\begin{array}{c}- \\
0,17\end{array}$ & $-0,37$ & $\begin{array}{c}- \\
0,42\end{array}$ & $-0,07$ & 0,03 \\
\hline P13 & 0,25 & $-0,99$ & $-0,99$ & 0,11 & 0,04 & $\begin{array}{c}- \\
0,06\end{array}$ & 0,02 & 0,42 \\
\hline P14 & 0,24 & $-1,04$ & $-2,27$ & 0,02 & $-0,10$ & $\begin{array}{c}- \\
0,95\end{array}$ & $-0,52$ & $-0,14$ \\
\hline
\end{tabular}

Anexo 6: $I_{\text {geo }}$ Calculado para Elementos- Traço $(\mathrm{mg} / \mathrm{L})$.

\begin{tabular}{|c|c|c|c|c|c|c|c|c|c|c|c|c|c|c|c|}
\hline & $\mathbf{S r}$ & $\mathbf{B a}$ & $\mathbf{Y}$ & La & $\mathbf{V}$ & $\mathrm{Cr}$ & Mo & Mn & Co & $\mathbf{N i}$ & $\mathbf{C u}$ & $\mathbf{Z n}$ & Cd & $\mathbf{P}$ & $\mathbf{P b}$ \\
\hline P1 & $-0,58$ & $-0,58$ & 0,58 & $-0,58$ & $-0,58$ & $-0,58$ & $-0,58$ & $-0,58$ & $-0,58$ & 0,58 & $-0,58$ & $-0,58$ & $-0,58$ & $-0,58$ & $-0,58$ \\
\hline P2 & 0,57 & $-0,24$ & $\begin{array}{c}- \\
1,83\end{array}$ & $-1,44$ & $-0,42$ & $-1,06$ & $-0,23$ & $-0,37$ & $-0,81$ & 0,77 & $-0,86$ & $-1,06$ & $-0,24$ & $-0,58$ & $-0,30$ \\
\hline P3 & 1,33 & 1,00 & $\begin{array}{c}- \\
0,33\end{array}$ & $-0,19$ & $-1,01$ & $-0,58$ & $-0,99$ & 1,00 & $-0,22$ & $\begin{array}{c}- \\
0,13\end{array}$ & 0,26 & 0,56 & $-1,13$ & $-0,08$ & $-0,30$ \\
\hline P4 & 2,13 & 1,66 & $\begin{array}{c}- \\
0,76\end{array}$ & $-0,25$ & $-1,02$ & $-0,55$ & $-1,10$ & 1,27 & 0,10 & 0,06 & 1,02 & 0,99 & $-1,06$ & 0,30 & $-0,38$ \\
\hline P5 & $-7,08$ & 0,52 & $0 \overline{76}$ & $-0,58$ & $-1,14$ & $-0,62$ & $-1,01$ & 0,34 & $-0,30$ & $\overline{0,24}$ & $-0,36$ & 0,29 & $-0,97$ & 0,19 & $-0,41$ \\
\hline P6 & $-0,05$ & 1,53 & $\begin{array}{c}- \\
1,20\end{array}$ & $-0,44$ & $-1,89$ & $-0,47$ & $-1,74$ & 2,96 & 1,56 & 0,09 & 1,07 & 0,58 & $-1,51$ & $-0,46$ & $-0,76$ \\
\hline P7 & $-0,17$ & 0,87 & 0,21 & 0,07 & $-1,43$ & $-0,87$ & $-1,28$ & 1,91 & 0,58 & $\overline{0} \overline{0}$ & 0,32 & 0,64 & $-1,28$ & 0,13 & $-0,95$ \\
\hline P8 & 0,42 & 0,01 & $\begin{array}{c}- \\
0,53\end{array}$ & $-0,79$ & $-2,10$ & $-1,37$ & $-2,06$ & 1,09 & $-0,87$ & $\begin{array}{c}- \\
1,30\end{array}$ & 0,01 & 0,51 & $-2,97$ & $-0,46$ & $-0,70$ \\
\hline P9 & 0,70 & 0,68 & 0,80 & 0,83 & $-1,27$ & $-0,97$ & $-1,23$ & $-0,05$ & $-1,22$ & $\begin{array}{c}- \\
0,63\end{array}$ & $-0,70$ & $-0,71$ & $-1,97$ & $-0,06$ & $-0,77$ \\
\hline $\mathbf{P 1 0}$ & 3,85 & 0,78 & 1,00 & 0,66 & $-1,58$ & $-1,03$ & $-1,35$ & 0,95 & 0,22 & $\begin{array}{c}- \\
0,40\end{array}$ & $-0,38$ & 0,14 & $-1,54$ & $-0,09$ & $-0,18$ \\
\hline P11 & $-0,05$ & 0,67 & 1,50 & 1,06 & $-1,26$ & $-0,68$ & $-1,07$ & $-0,48$ & $-0,11$ & $\overline{-}, 04$ & 0,19 & 0,61 & $-0,91$ & 0,06 & 0,33 \\
\hline P12 & 0,64 & 0,66 & 0,21 & 0,23 & $-1,22$ & $-0,91$ & $-1,04$ & 2,44 & 0,93 & $\begin{array}{c}- \\
0,09\end{array}$ & 0,13 & 0,64 & $-1,02$ & 0,19 & $-0,27$ \\
\hline P13 & 2,42 & 0,60 & $\begin{array}{c}- \\
0,64\end{array}$ & $-0,25$ & $-1,13$ & $-0,83$ & $-1,08$ & 1,12 & $-0,26$ & $\begin{array}{c}- \\
0,42\end{array}$ & 0,38 & 0,49 & $-1,45$ & 0,12 & $-0,49$ \\
\hline P14 & 1,10 & 0,55 & $\begin{array}{c}- \\
0,38\end{array}$ & $-0,10$ & $-1,35$ & $-0,76$ & $-1,25$ & 0,71 & $-0,69$ & $\begin{array}{c}- \\
0,54\end{array}$ & 0,22 & 0,19 & $-1,45$ & 0,04 & $-0,56$ \\
\hline
\end{tabular}


Anexo 7: Difratogramas obtidos nas análises mineralógicas.

\section{Ponto 1}

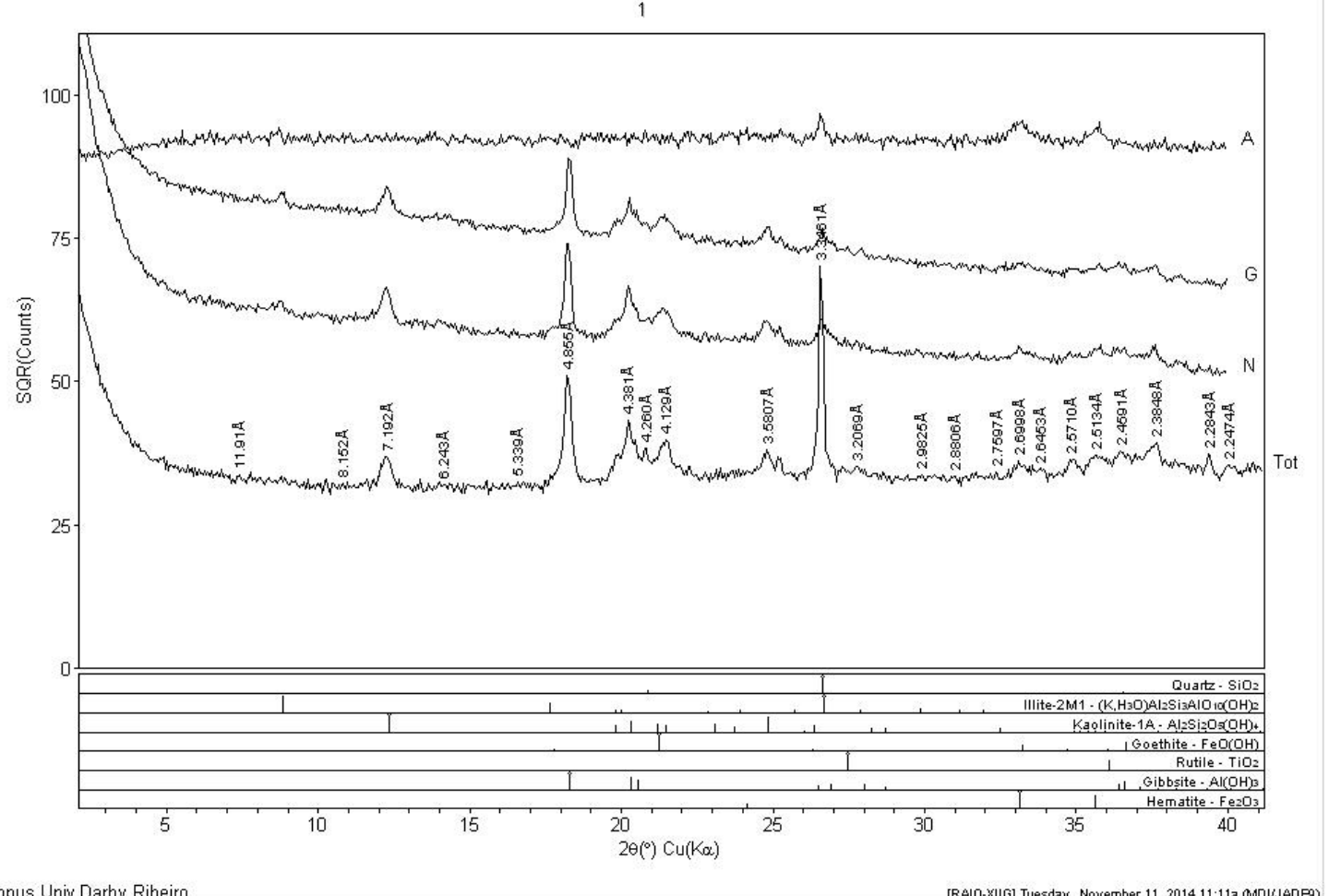

Campus Univ Darby Ribeiro

[RAO-X||G] Tuesday, November 11, 2014 11:11a (MDIJJADE9)

Ponto 2

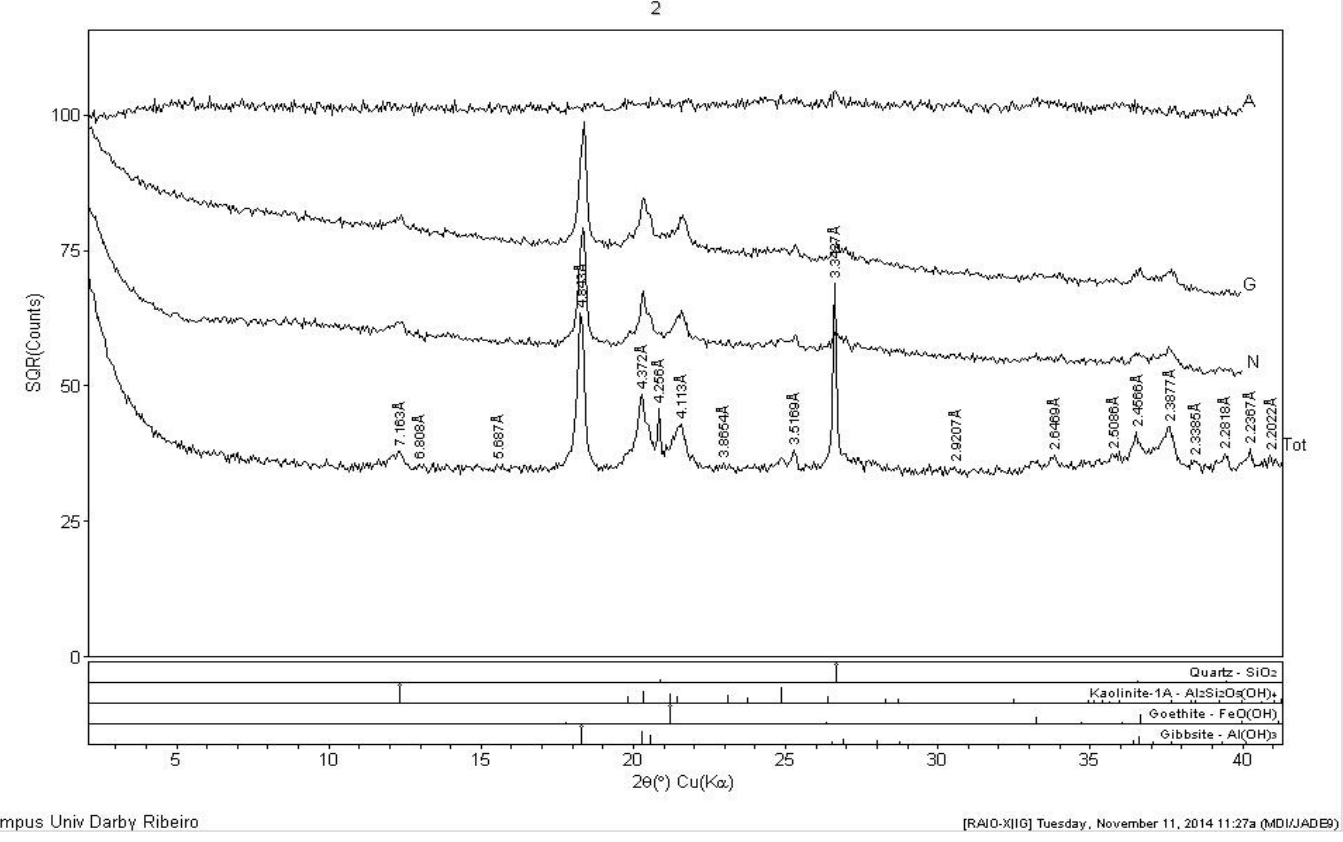




\section{Ponto 3}

3

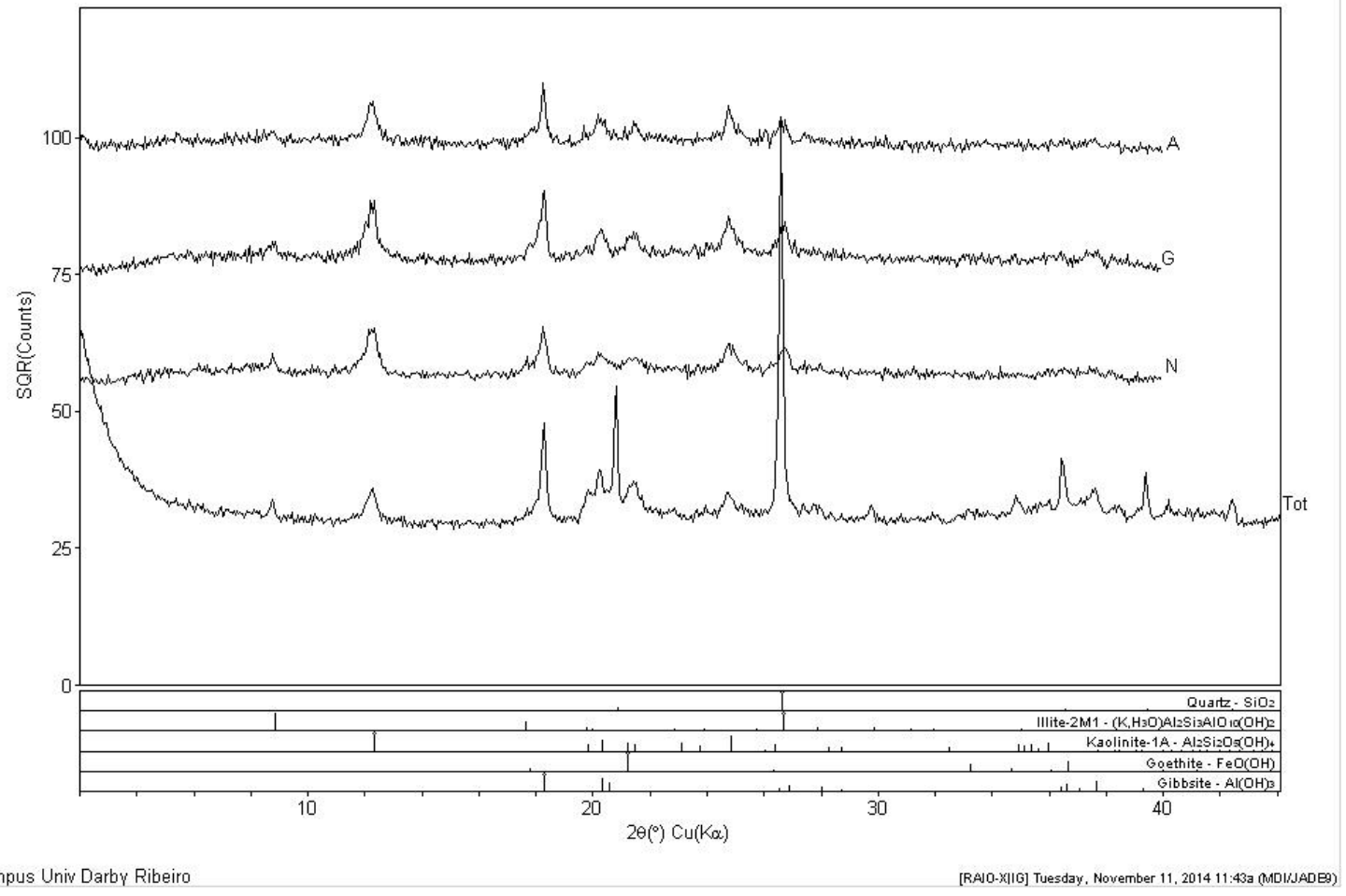

\section{Ponto 4}

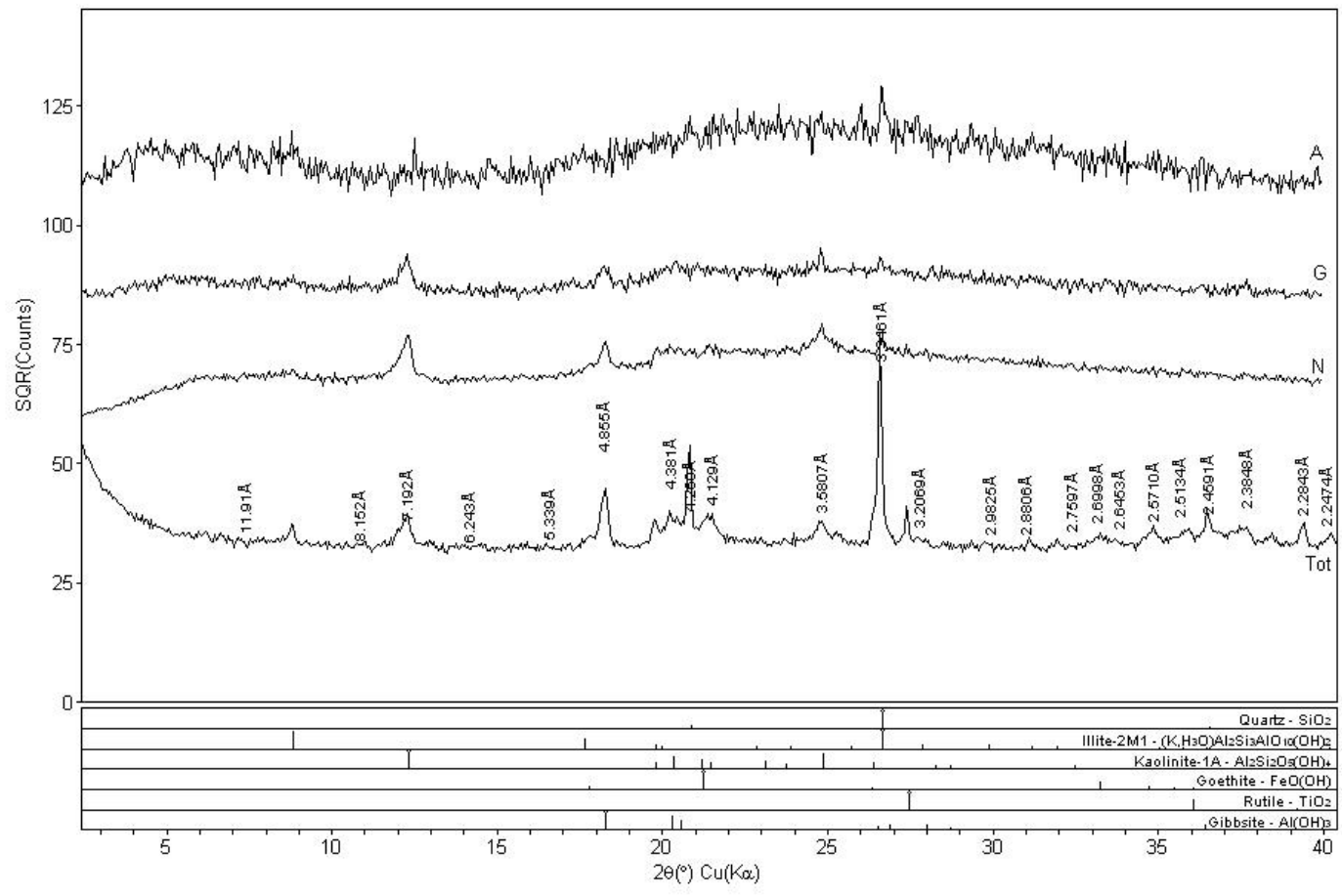




\section{Ponto 5}

5

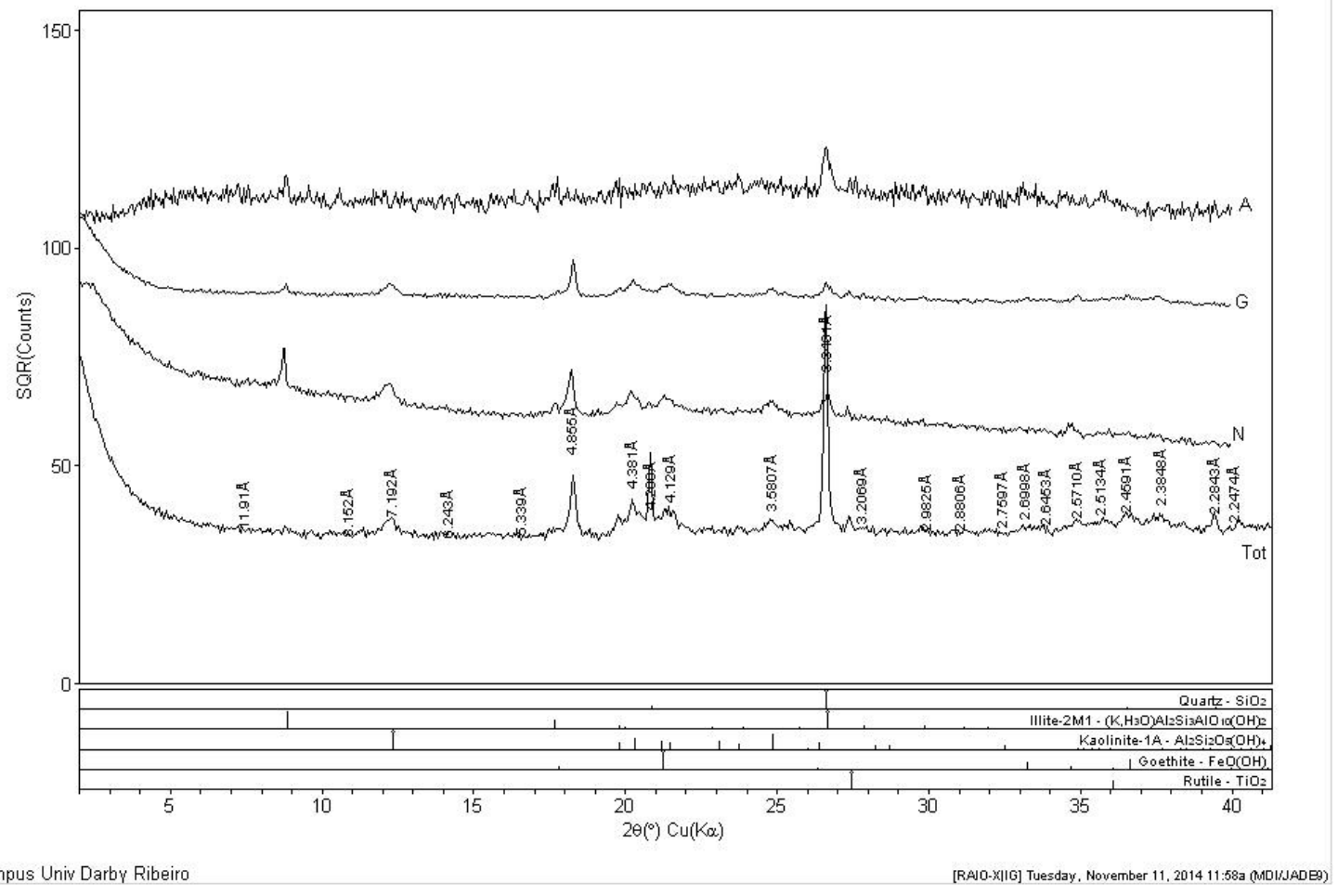

\section{Ponto 6}

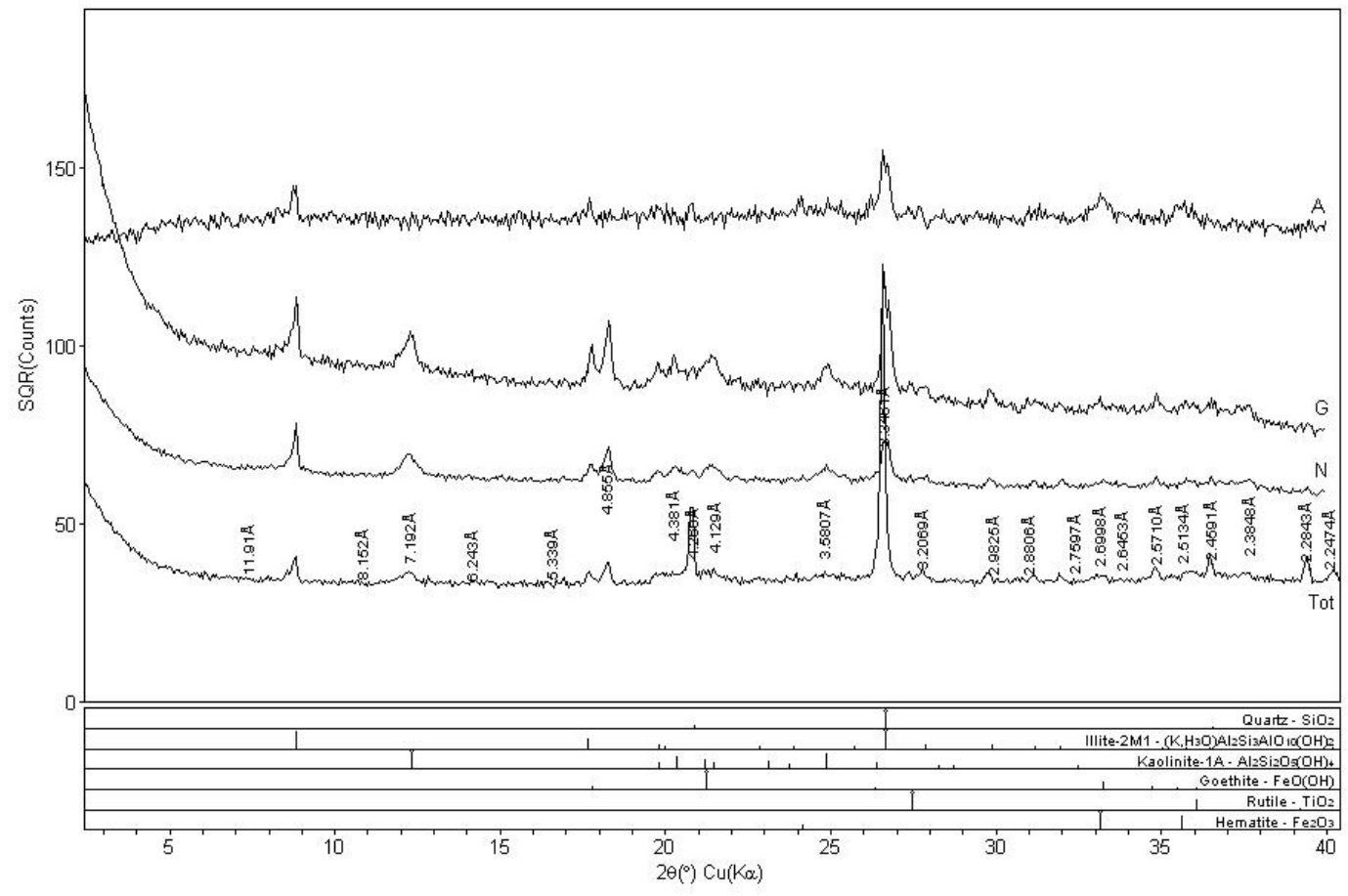




\section{Ponto 7}

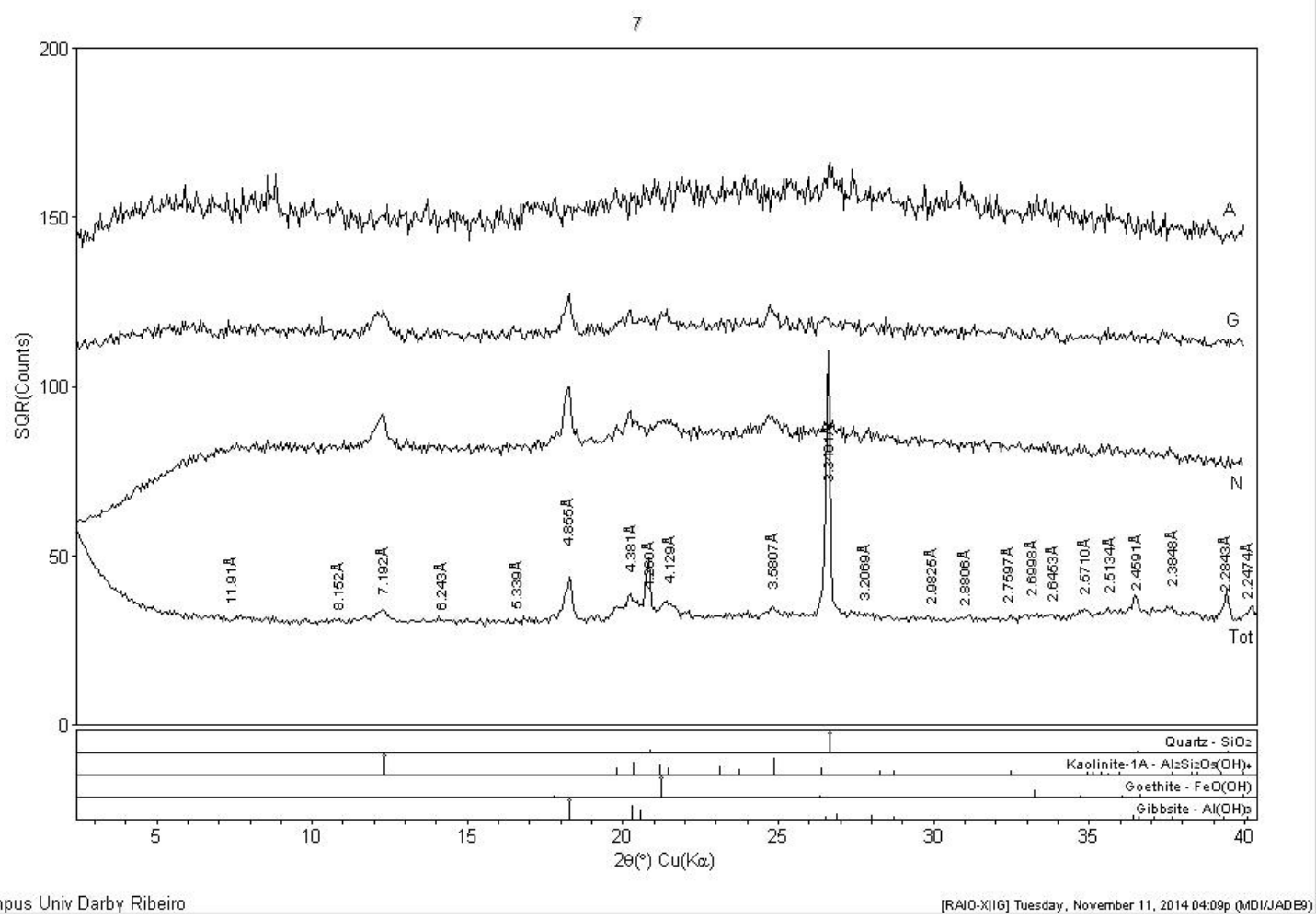

Ponto 8

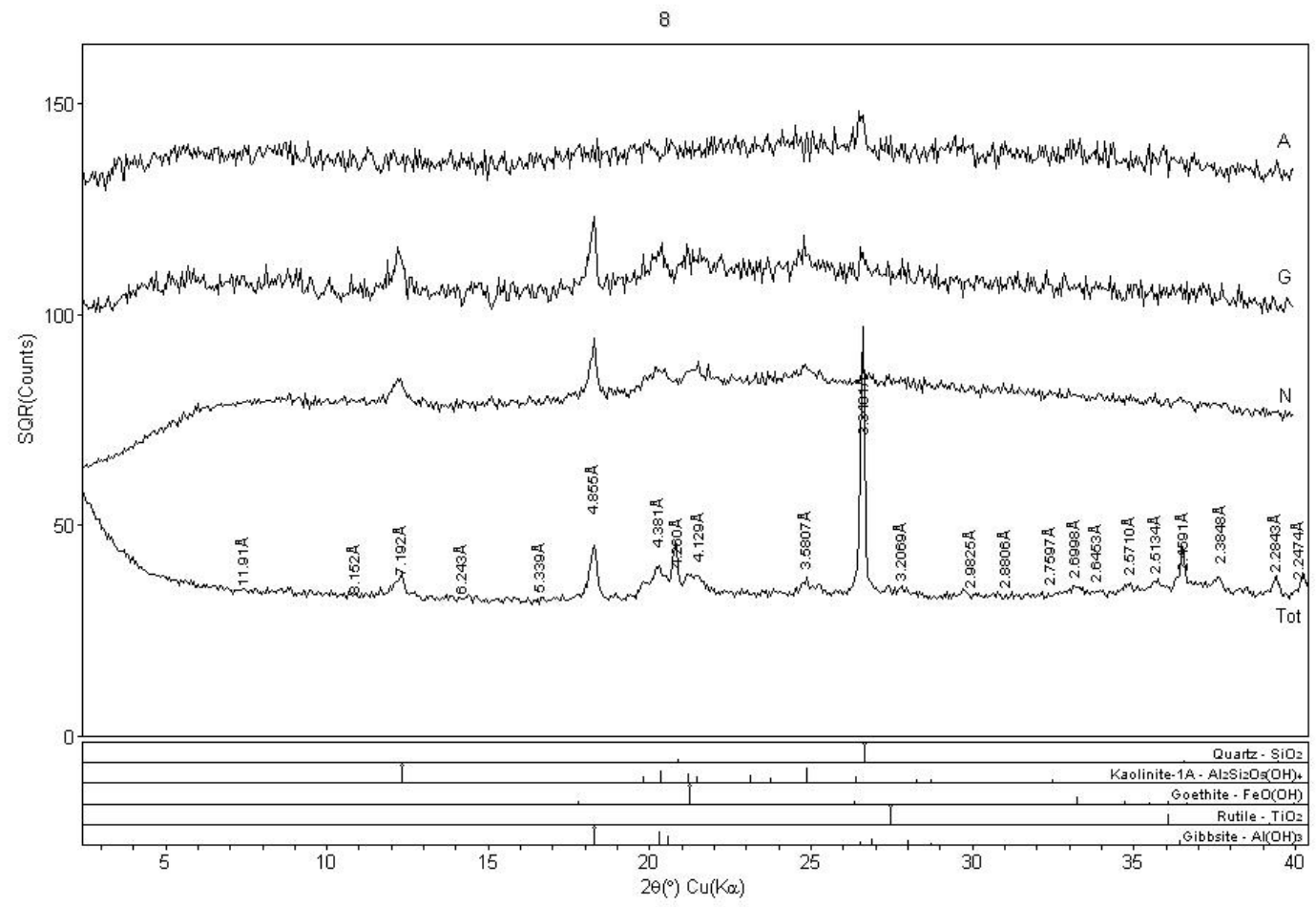




\section{Ponto 9}
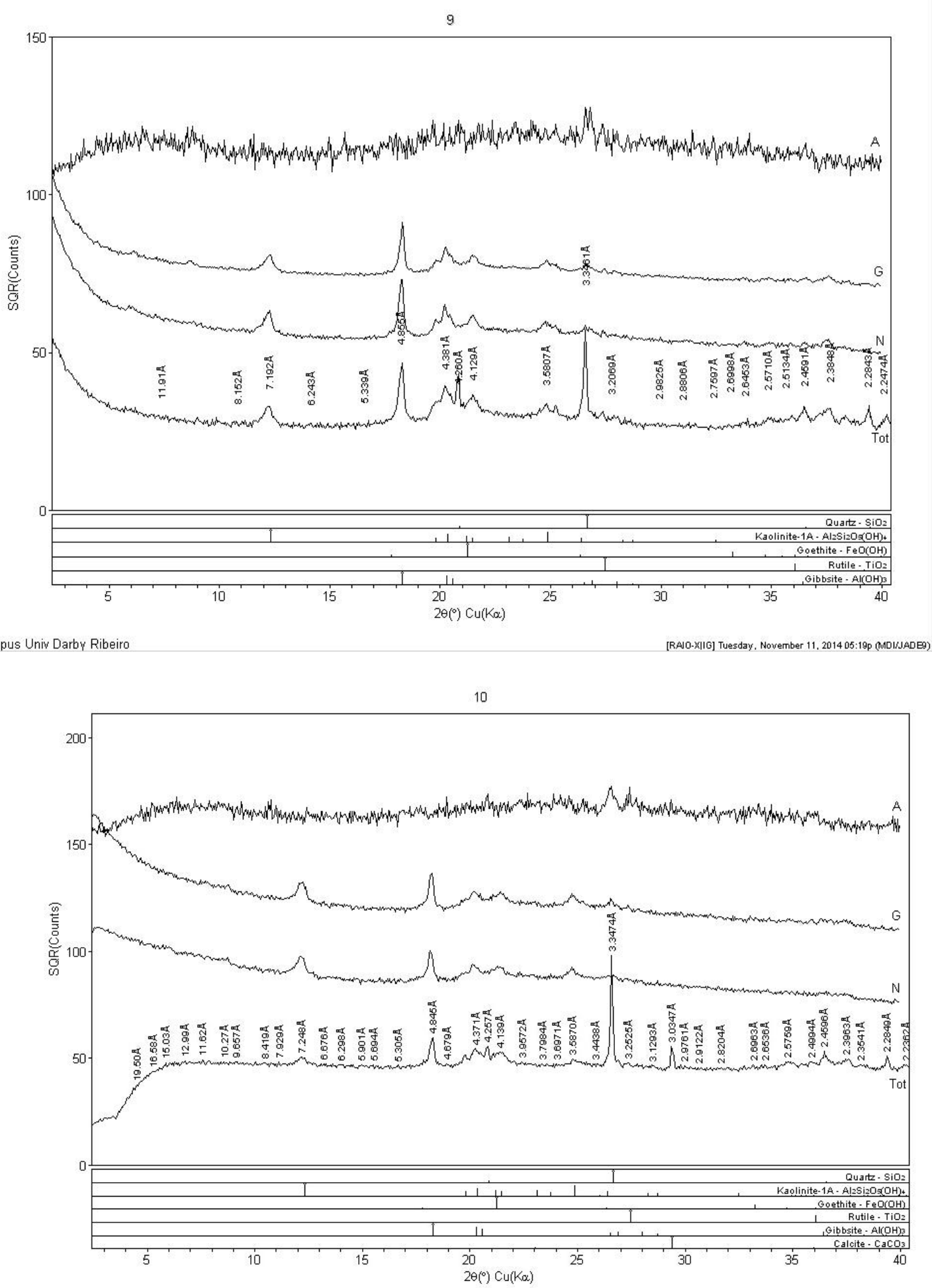

Ponto 10 pus Univ Darby Ribeiro 
Ponto 11

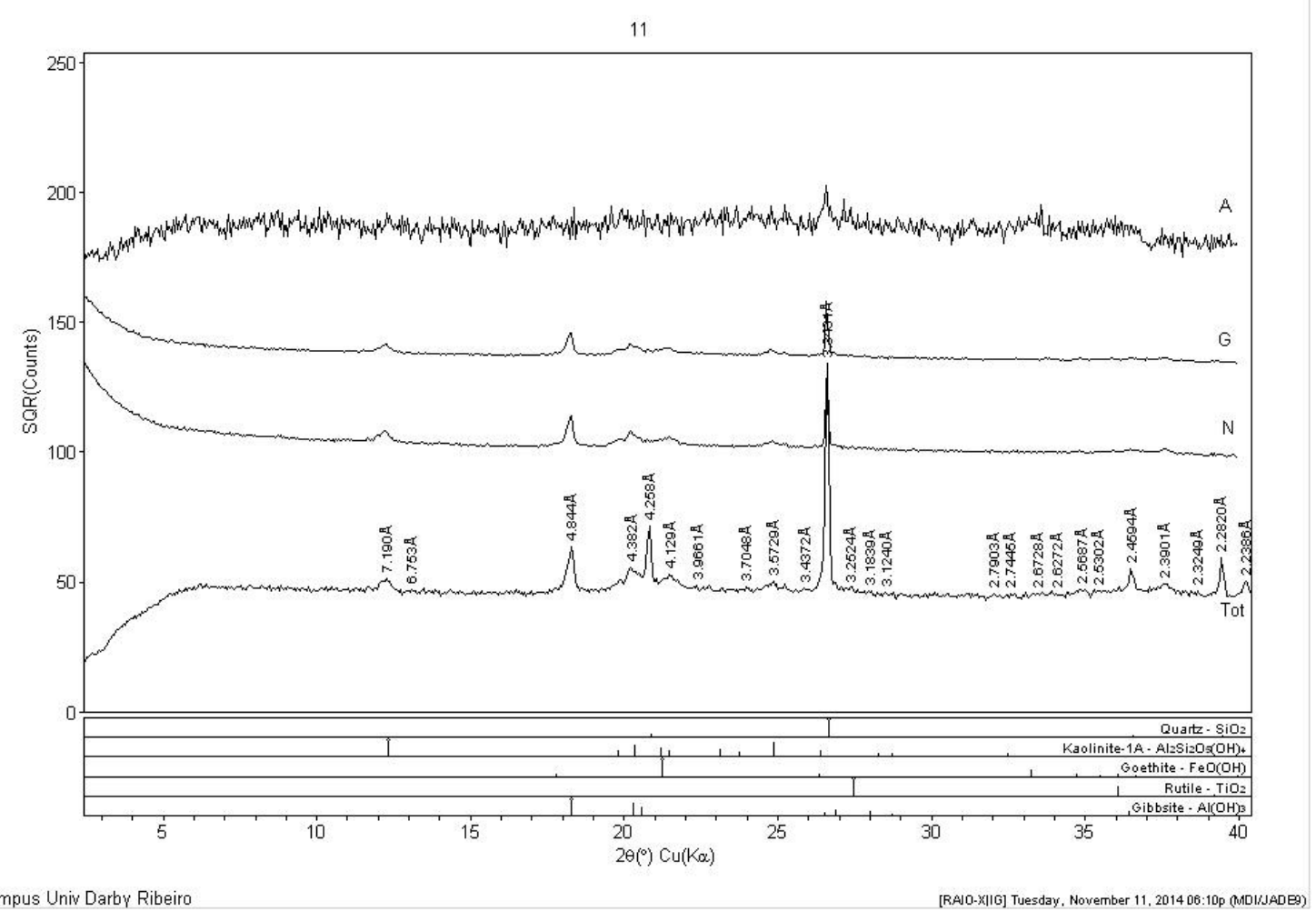

Ponto 12

12

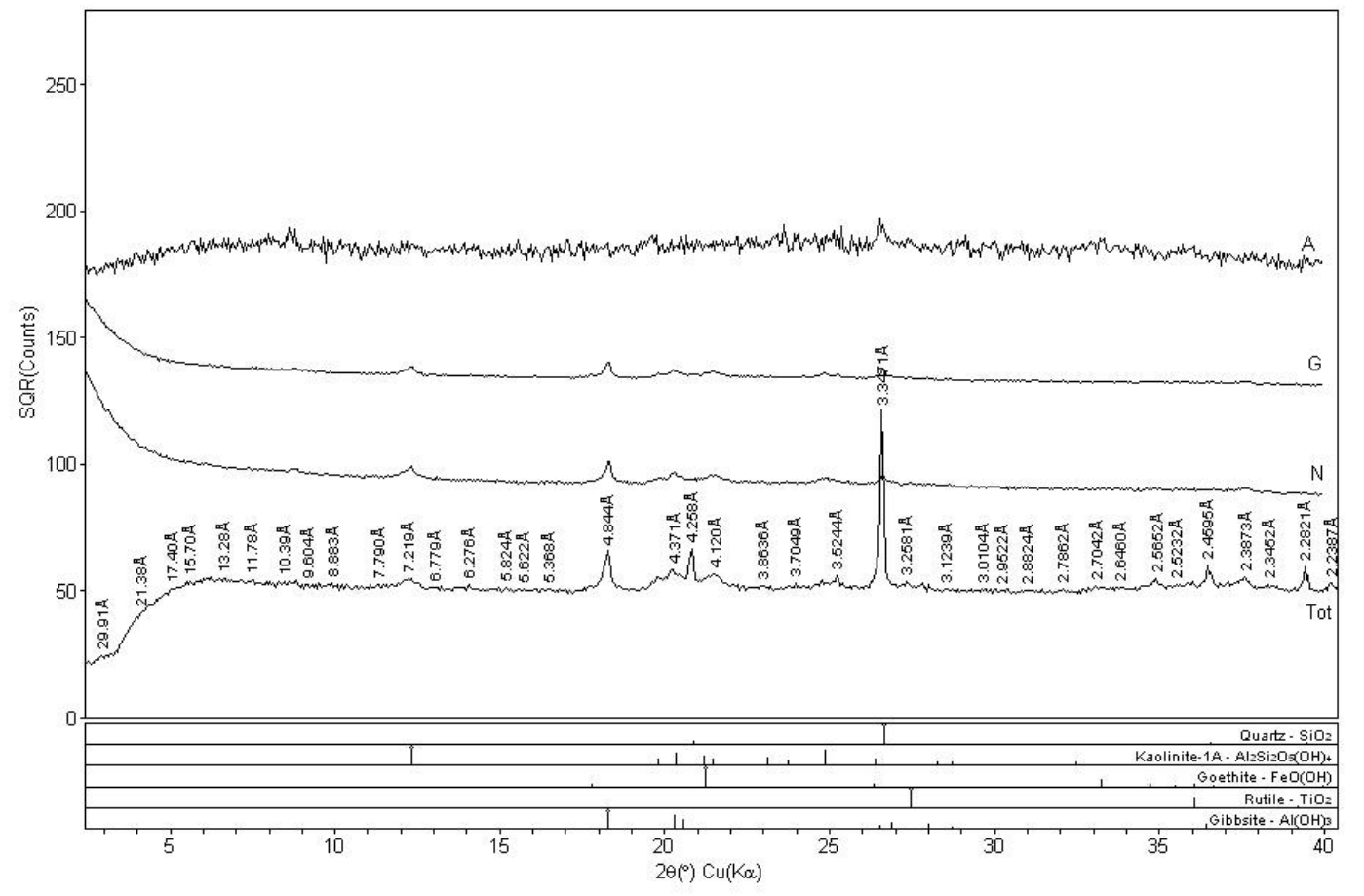


Ponto 13

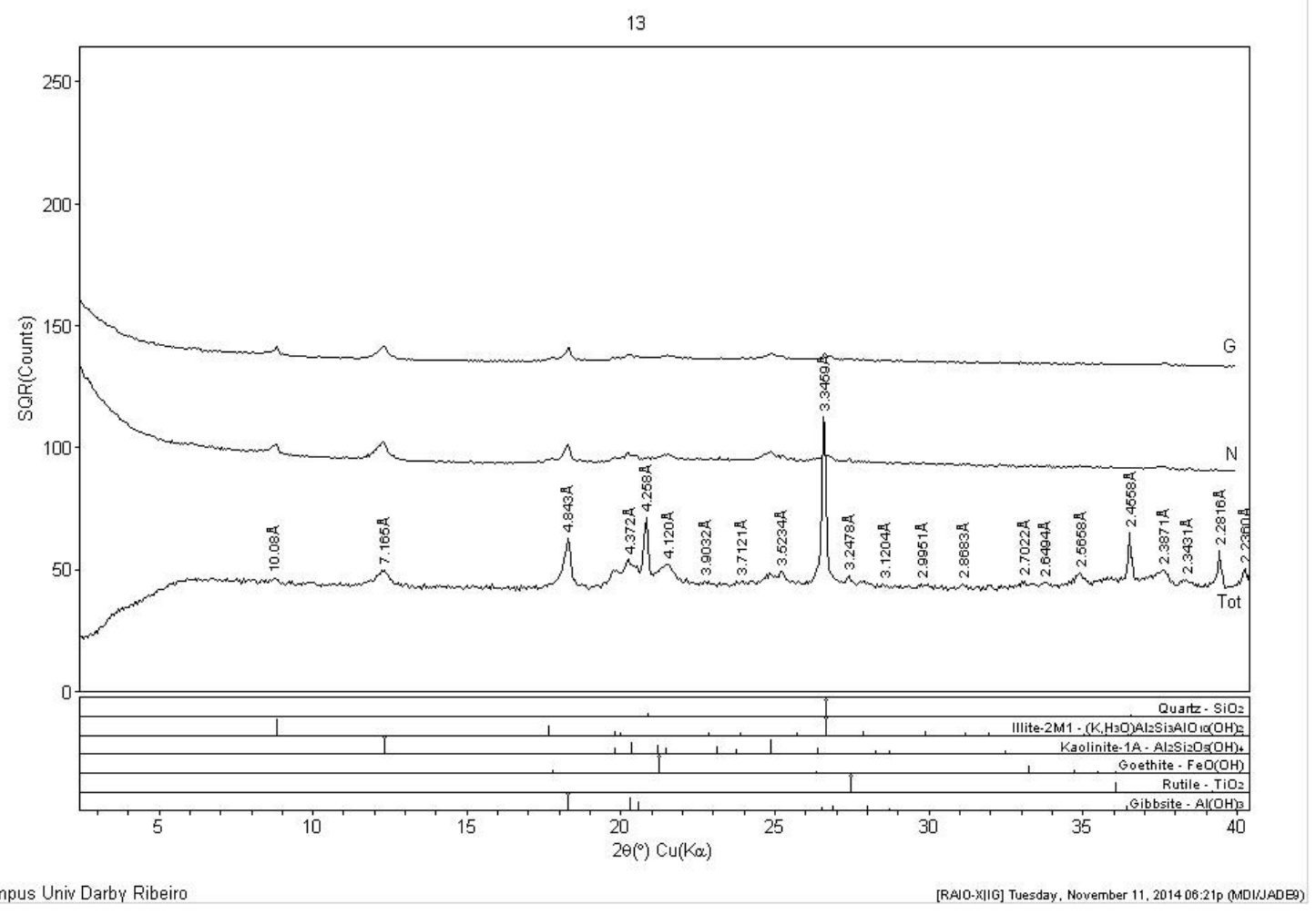

Ponto 14

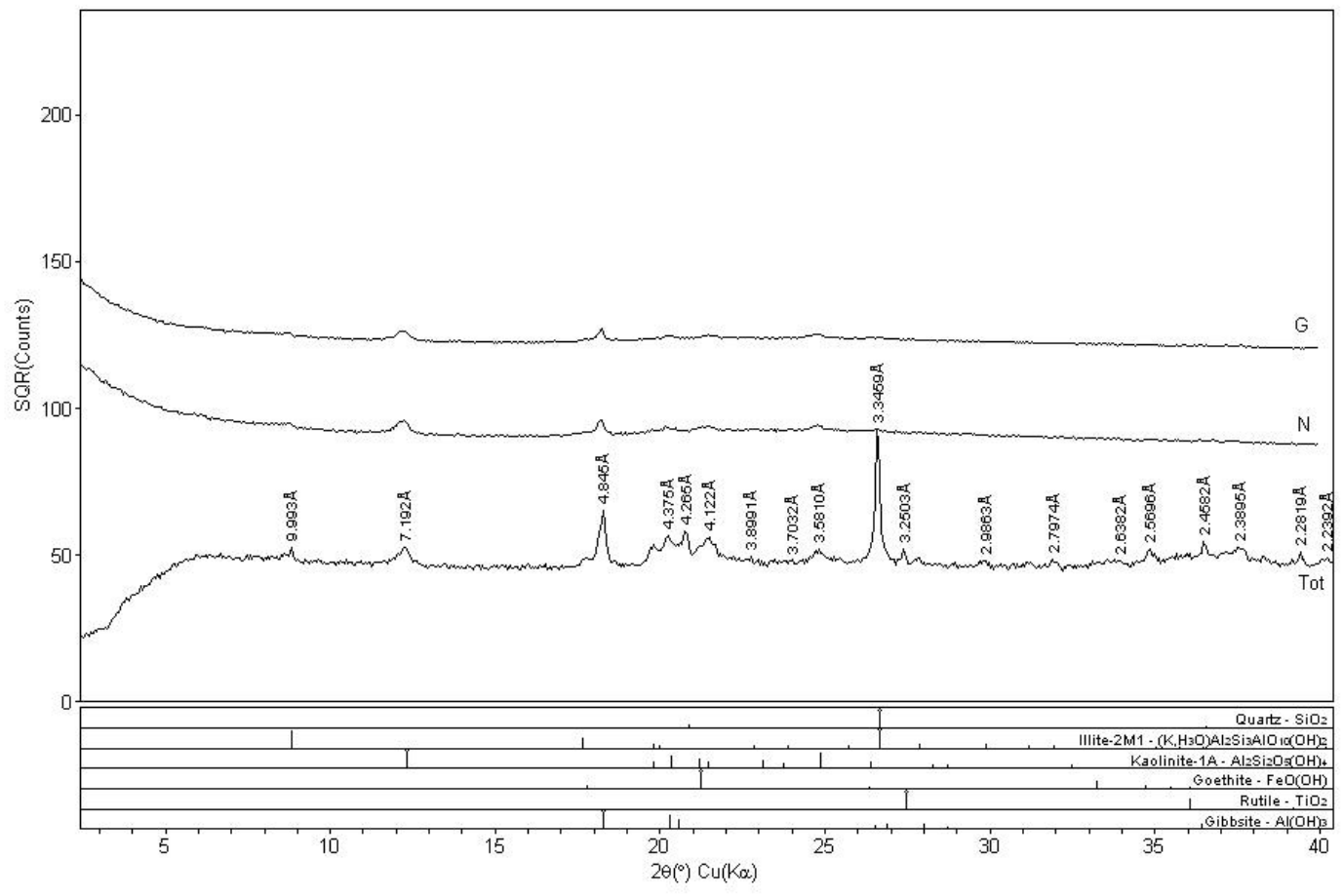


Anexo 8: Análise Principais Componentes- Água-Estação Seca.

\begin{tabular}{|c|c|c|c|}
\hline & \multicolumn{2}{|c|}{ Pesos PC's } & \\
\hline $\mathbf{p H}$ & $\mathbf{1}$ & $\mathbf{2}$ & Comunalities \\
\hline $\mathbf{C . E}$ & $-0,22$ & 0,46 & 0,76 \\
\hline $\mathbf{C a}$ & $-0,01$ & 0,31 & 0,96 \\
\hline $\mathbf{M g}$ & $-0,01$ & 0,46 & 0,91 \\
\hline $\mathbf{N a}$ & 0,25 & $-0,22$ & 0,69 \\
\hline $\mathbf{K}$ & 0,35 & $-0,12$ & 0,79 \\
\hline $\mathbf{C l}$ & 0,43 & $-0,25$ & 0,72 \\
\hline Variância & 0.28 & $-0,03$ & 0,85 \\
\hline
\end{tabular}

Anexo 9: Análise Principais Componentes- Água-Estação Chuvosa.

\begin{tabular}{|c|c|c|c|}
\hline & \multicolumn{2}{|c|}{ Pesos PC's } & \\
\hline & $\mathbf{1}$ & $\mathbf{2}$ & Comunalities \\
\hline $\mathbf{p H}$ & 0,78 & 0,20 & 0,65 \\
\hline $\mathbf{C . E}$ & 0,92 & 0,35 & 0,97 \\
\hline $\mathbf{C a}$ & 0,93 & 0,15 & 0,89 \\
\hline $\mathbf{M g}$ & 0,73 & 0,45 & 0,74 \\
\hline $\mathbf{N a}$ & 0,36 & 0,89 & 0,93 \\
\hline $\mathbf{K}$ & 0,40 & 0,46 & 0,38 \\
\hline $\mathbf{N O} \mathbf{O}_{3}$ & 0,63 & 0,65 & 0,82 \\
\hline Alcalinidade & 0,93 & 0,29 & 0,96 \\
\hline $\mathbf{C l}$ & 0,07 & 0,87 & 0,77 \\
\hline Variância & $66,21 \%$ & $13,02 \%$ & - \\
\hline
\end{tabular}


Anexo 10: Análise Principais Componentes- Sedimento- Estação Seca.

\begin{tabular}{|c|c|c|c|}
\hline & \multicolumn{2}{|c|}{ Pesos PC's } & \\
\hline & 1 & $\mathbf{2}$ & Comunalities \\
\hline $\mathbf{S i O}_{2}$ & $-0,02$ & 0,24 & 0,72 \\
\hline $\mathbf{A l}_{\mathbf{2}} \mathbf{O}_{\mathbf{3}}$ & 0,06 & $-0,23$ & 0,59 \\
\hline $\mathbf{C a O}$ & 0,06 & $-0,03$ & 0,07 \\
\hline $\mathbf{M g O}$ & 0,11 & 0,06 & 0,41 \\
\hline $\mathbf{T i O}_{\mathbf{2}}$ & 0,14 & $-0,11$ & 0,37 \\
\hline $\mathbf{N a}_{\mathbf{2}} \mathbf{O}$ & 0,11 & $-0,03$ & 0,20 \\
\hline $\mathbf{K}_{\mathbf{2}} \mathbf{O}$ & 0,04 & 0,16 & 0,45 \\
\hline $\mathbf{S r}$ & 0,08 & $-0,22$ & 0,56 \\
\hline $\mathbf{B a}$ & 0,11 & 0,12 & 0,63 \\
\hline $\mathbf{V}$ & $-0,19$ & 0,08 & 0,60 \\
\hline $\mathbf{C r}$ & $-0,04$ & 0,22 & 0,58 \\
\hline $\mathbf{M o}$ & $-0,18$ & 0,23 & 0,59 \\
\hline $\mathbf{M n}$ & 0,17 & $-0,04$ & 0,49 \\
\hline $\mathbf{C u}$ & 0,15 & 0,05 & 0,60 \\
\hline $\mathbf{Z n}$ & 0,18 & 0,05 & 0,79 \\
\hline Variância & $31,29 \%$ & $20,22 \%$ & - \\
\hline
\end{tabular}


Anexo 11: Balanço iônico- Água- Estação Chuvosa.

\begin{tabular}{|c|c|c|c|c|c|c|c|c|c|c|c|c|c|c|c|c|c|c|c|c|c|c|c|c|c|}
\hline & & \multicolumn{8}{|c|}{ CATIONS } & \multicolumn{12}{|c|}{ ANIONS } & \multicolumn{3}{|c|}{ BALANÇO IÔNICO } & \multirow[t]{2}{*}{ E.P } \\
\hline & & \multicolumn{2}{|c|}{$\mathbf{C a}$} & \multicolumn{2}{|c|}{ Mg } & \multicolumn{2}{|c|}{$\mathbf{N a}$} & \multicolumn{2}{|c|}{$\mathbf{K}$} & \multicolumn{2}{|c|}{$\mathbf{F}$} & \multicolumn{2}{|c|}{$\mathbf{C l}$} & \multicolumn{2}{|c|}{$\mathrm{NO}_{3}$} & \multicolumn{2}{|c|}{$\mathbf{P O}_{4}$} & \multicolumn{2}{|c|}{$\mathrm{SO}_{4}$} & \multicolumn{2}{|c|}{$\mathrm{HCO}_{3}$} & Soma & C. E. & Soma & \\
\hline & $\mathrm{pH}$ & $\mathrm{mgL}$ & meq & $\mathrm{mgL}$ & meq & $\mathrm{mgL}$ & Meq & $\mathrm{mgL}$ & meq & $\mathrm{mgL}$ & meq & $\mathrm{mgL}$ & meq & $\mathrm{mgL}$ & meq & $\mathrm{mg} /$ & meq & $\mathrm{mgL}$ & meq & $\mathrm{mg} / \mathrm{L}$ & meq & Anions & $\mu \mathrm{S}$ & Cations & \\
\hline P1 & 5,66 & 0,90 & 0,04 & 0,11 & 0,01 & 0,40 & 0,02 & 0,12 & 0,00 & 0,02 & 0,00 & 0,23 & 0,01 & 0,35 & 0,01 & 0,00 & 0,00 & 0,00 & 0,00 & 3,62 & 0,06 & 0,073 & 7,080 & 0,075 & 1,40 \\
\hline $\mathbf{P 2}$ & 5,64 & 1,30 & 0,06 & 0,07 & 0,01 & 0,33 & 0,01 & 0,10 & 0,00 & 0,00 & 0,00 & 0,39 & 0,01 & 0,33 & 0,01 & 0,00 & 0,00 & 0,00 & 0,00 & 4,80 & 0,08 & 0,095 & 9,490 & 0,087 & $-4,09$ \\
\hline P3 & 6,42 & 6,18 & 0,31 & 0,35 & 0,03 & 2,05 & 0,09 & 0,40 & 0,01 & 0,01 & 0,00 & 2,26 & 0,06 & 3,06 & 0,05 & 0,00 & 0,00 & 0,38 & 0,01 & 19,44 & 0,32 & 0,440 & 44,700 & 0,436 & $-0,46$ \\
\hline P4 & 6,38 & 1,16 & 0,06 & 0,24 & 0,02 & 1,30 & 0,06 & 0,80 & 0,02 & 0,00 & 0,00 & 0,39 & 0,01 & 0,56 & 0,01 & 0,00 & 0,00 & 0,42 & 0,01 & 7,28 & 0,12 & 0,148 & 15,190 & 0,155 & 2,28 \\
\hline P5 & 6,56 & 1,29 & 0,06 & 0,22 & 0,02 & 0,50 & 0,02 & 0,25 & 0,01 & 0,00 & 0,00 & 0,25 & 0,01 & 0,34 & 0,01 & 0,00 & 0,00 & 0,26 & 0,01 & 5,39 & 0,09 & 0,106 & 11,970 & 0,111 & 1,98 \\
\hline P6 & 5,63 & 0,45 & 0,02 & 0,13 & 0,01 & 0,60 & 0,03 & 0,10 & 0,00 & 0,00 & 0,00 & 0,38 & 0,01 & 0,37 & 0,01 & 0,00 & 0,00 & 0,00 & 0,00 & 2,89 & 0,05 & 0,064 & 6,420 & 0,061 & $-2,18$ \\
\hline $\mathbf{P 7}$ & 6,56 & 1,76 & 0,09 & 0,29 & 0,02 & 3,50 & 0,15 & 0,30 & 0,01 & 0,01 & 0,00 & 1,15 & 0,03 & 2,68 & 0,04 & 0,00 & 0,00 & 0,32 & 0,01 & 11,37 & 0,19 & 0,269 & 27,400 & 0,271 & 0,37 \\
\hline P8 & 6,58 & 8,38 & 0,42 & 0,44 & 0,04 & 2,00 & 0,09 & 0,55 & 0,01 & 0,01 & 0,00 & 2,70 & 0,08 & 4,24 & 0,07 & 0,00 & 0,00 & 0,45 & 0,01 & 24,88 & 0,41 & 0,562 & 56,400 & 0,555 & $-0,62$ \\
\hline P9 & 6,01 & 1,05 & 0,05 & 0,21 & 0,02 & 0,56 & 0,02 & $\overline{0,10}$ & 0,00 & 0,00 & 0,00 & 0,51 & 0,01 & 0,55 & 0,01 & 0,00 & 0,00 & 0,32 & 0,01 & 4,53 & 0,07 & 0,104 & 10,050 & 0,096 & $-4,07$ \\
\hline P10 & 5,83 & 0,95 & 0,05 & 0,14 & 0,01 & 0,47 & 0,02 & 0,10 & 0,00 & 0,01 & 0,00 & 0,41 & 0,01 & 0,38 & 0,01 & 0,00 & 0,00 & 0,00 & 0,00 & 3,58 & 0,06 & 0,077 & 8,240 & 0,082 & 3,23 \\
\hline P11 & 5,90 & 0,70 & 0,03 & 0,15 & 0,01 & 0,45 & 0,02 & 0,08 & 0,00 & 0,01 & 0,00 & 0,41 & 0,01 & 0,31 & 0,00 & 0,00 & 0,00 & 0,24 & 0,00 & 3,18 & 0,05 & 0,074 & 7,880 & 0,069 & $-3,73$ \\
\hline P12 & 5,84 & 0,81 & 0,04 & 0,15 & 0,01 & 0,50 & 0,02 & 0,06 & 0,00 & 0,01 & 0,00 & 0,35 & 0,01 & 0,32 & 0,01 & 0,00 & 0,00 & 0,00 & 0,00 & 4,10 & 0,07 & 0,083 & 8,180 & 0,076 & $-4,22$ \\
\hline P13 & 5,63 & 0,13 & 0,01 & 0,05 & 0,00 & 0,42 & 0,02 & 0,08 & 0,00 & 0,00 & 0,00 & 0,10 & 0,00 & 0,30 & 0,00 & 0,00 & 0,00 & 0,00 & 0,00 & 1,01 & 0,02 & 0,024 & 2,360 & 0,031 & 11,4 \\
\hline P14 & 6,60 & 4,75 & 0,24 & 0,15 & 0,01 & 1,08 & 0,05 & 0,08 & 0,00 & 0,41 & 0,02 & 0,70 & 0,02 & 0,36 & 0,01 & 0,00 & 0,00 & 0,68 & 0,01 & 14,79 & 0,24 & 0,304 & 30,100 & 0,298 & $-0,95$ \\
\hline P15 & 6,57 & 4,29 & 0,21 & 0,16 & 0,01 & 1,01 & 0,04 & 0,08 & 0,00 & 0,02 & 0,00 & 0,43 & 0,01 & 0,33 & 0,01 & 0,00 & 0,00 & 0,60 & 0,01 & 14,34 & 0,23 & 0,266 & 27,000 & 0,273 & 1,33 \\
\hline P16 & 6,64 & 5,02 & 0,25 & 0,13 & 0,01 & 0,80 & 0,03 & 0,10 & 0,00 & 0,52 & 0,03 & 1,12 & 0,03 & 0,34 & 0,01 & 0,00 & 0,00 & 0,75 & 0,02 & 13,36 & 0,22 & 0,299 & 30,000 & 0,298 & $-0,13$ \\
\hline P17 & 6,43 & 1,72 & 0,09 & 0,29 & 0,02 & 0,00 & 0,00 & 0,00 & 0,00 & 0,00 & 0,00 & 1,03 & 0,03 & 0,86 & 0,01 & 0,00 & 0,00 & 0,00 & 0,00 & 9,59 & 0,16 & 0,200 & 20,900 & 0,110 & $-29,1$ \\
\hline
\end{tabular}

\section{E.P: Erro Prático}


Anexo 12: Balanço iônico- Água- Estação Seca.

\begin{tabular}{|c|c|c|c|c|c|c|c|c|c|c|c|c|c|c|c|c|c|c|c|c|c|c|c|c|c|}
\hline & & \multicolumn{8}{|c|}{ CATIONS } & \multicolumn{12}{|c|}{ ANIONS } & \multicolumn{3}{|c|}{ BALANÇO IÔNICO } & \multirow[t]{2}{*}{ E.P } \\
\hline & & \multicolumn{2}{|c|}{$\mathbf{C a}$} & \multicolumn{2}{|c|}{$\mathbf{M g}$} & \multicolumn{2}{|c|}{$\mathbf{N a}$} & \multicolumn{2}{|c|}{$\mathbf{K}$} & \multicolumn{2}{|c|}{$\mathbf{F}$} & \multicolumn{2}{|c|}{$\mathbf{C l}$} & \multicolumn{2}{|c|}{$\mathrm{NO}_{3}$} & \multicolumn{2}{|c|}{$\mathrm{PO}_{4}$} & \multicolumn{2}{|c|}{$\mathrm{SO}_{4}$} & \multicolumn{2}{|c|}{$\mathrm{HCO}_{3}$} & Soma & C. E. & Soma & \\
\hline & $\mathrm{pH}$ & $\mathrm{mgL}$ & meq & $\mathrm{mgL}$ & meq & $\mathrm{mgL}$ & Meq & $\mathrm{mgL}$ & meq & $\mathrm{mgL}$ & meq & $\mathrm{mgL}$ & meq & $\mathrm{mgL}$ & meq & $\mathrm{mg} /$ & meq & $\mathrm{mgL}$ & meq & $\mathrm{mg} / \mathrm{L}$ & meq & Anions & $\mu \mathrm{S}$ & Cations & \\
\hline P1 & 5,12 & 0,55 & 0,03 & 0,19 & 0,02 & 0,24 & 0,01 & 0,10 & 0,00 & 0 & 0,00 & 0,34 & 0,01 & 0,00 & 0,00 & 0 & 0,00 & 0 & 0,00 & 3,09 & 0,05 & 0,06 & 5,47 & 0,06 & $-3,54$ \\
\hline P2 & 5,02 & 0,50 & 0,02 & 0,21 & 0,02 & 0,27 & 0,01 & 0,08 & 0,00 & 0 & 0,00 & 0,36 & 0,01 & 0,00 & 0,00 & 0 & 0,00 & 0 & 0,00 & 3,71 & 0,06 & 0,07 & 7,07 & 0,06 & $-11,8$ \\
\hline P3 & 5,80 & 1,86 & 0,09 & 0,18 & 0,01 & 2,01 & 0,09 & 0,34 & 0,01 & 0 & 0,00 & 1,56 & 0,04 & 1,97 & 0,03 & 0 & 0,00 & 0,52 & 0,01 & 8,09 & 0,13 & 0,22 & 22,50 & 0,20 & $-3,67$ \\
\hline P4 & 5,86 & 1,70 & 0,08 & 0,19 & 0,02 & 1,24 & 0,05 & 0,74 & 0,02 & 0 & 0,00 & 1,48 & 0,04 & 0,57 & 0,01 & 0 & 0,00 & 0,67 & 0,01 & 7,01 & 0,11 & 0,18 & 18,14 & 0,17 & $-1,83$ \\
\hline P5 & 5,68 & 0,93 & 0,05 & 0,21 & 0,02 & 0,44 & 0,02 & 0,21 & 0,01 & 0 & 0,00 & 0,56 & 0,02 & 0,14 & 0,00 & 0 & 0,00 & 0 & 0,00 & 5,27 & 0,09 & 0,10 & 9,99 & 0,09 & $-8,37$ \\
\hline P6 & 5,52 & 0,43 & 0,02 & 0,10 & 0,01 & 0,26 & 0,01 & 0,09 & 0,00 & 0 & 0,00 & 0,28 & 0,01 & 0,14 & 0,00 & 0 & 0,00 & 0 & 0,00 & 2,47 & 0,04 & 0,05 & 4,39 & 0,04 & $-7,52$ \\
\hline P7 & 5,89 & 0,97 & 0,05 & 0,25 & 0,02 & 1,43 & 0,06 & 0,27 & 0,01 & 0 & 0,00 & 1,15 & 0,03 & 0,90 & 0,01 & 0 & 0,00 & 0,2 & 0,00 & 6,09 & 0,10 & 0,15 & 14,61 & 0,14 & $-4,52$ \\
\hline P8 & 6,12 & 1,83 & 0,09 & 0,43 & 0,04 & 3,40 & 0,15 & 0,53 & 0,01 & 0 & 0,00 & 2,54 & 0,07 & 2,71 & 0,04 & 0 & 0,00 & 0,12 & 0,00 & 10,48 & 0,17 & 0,29 & 29,50 & 0,29 & $-0,22$ \\
\hline P9 & 5,74 & 0,45 & 0,02 & 0,22 & 0,02 & 0,39 & 0,02 & 0,06 & 0,00 & 0 & 0,00 & 0,28 & 0,01 & 0,45 & 0,01 & 0 & 0,00 & 0,07 & 0,00 & 2,78 & 0,05 & 0,06 & 5,78 & 0,06 & $-3,19$ \\
\hline P10 & 5,52 & 0,33 & 0,02 & 0,13 & 0,01 & 0,39 & 0,02 & 0,07 & 0,00 & 0 & 0,00 & 0,36 & 0,01 & 0,14 & 0,00 & 0 & 0,00 & 0 & 0,00 & 2,89 & 0,05 & 0,06 & 5,46 & 0,05 & $-13,5$ \\
\hline P11 & 5,73 & 0,44 & 0,02 & 0,10 & 0,01 & 0,40 & 0,02 & 0,06 & 0,00 & 0 & 0,00 & 0,41 & 0,01 & 0,00 & 0,00 & 0 & 0,00 & 0 & 0,00 & 2,97 & 0,05 & 0,06 & 5,20 & 0,05 & $-10,3$ \\
\hline P12 & 5,67 & 0,31 & 0,02 & 0,16 & 0,01 & 0,39 & 0,02 & 0,04 & 0,00 & 0 & 0,00 & 0,43 & 0,01 & 0,00 & 0,00 & 0 & 0,00 & 0 & 0,00 & 2,59 & 0,04 & 0,05 & 5,61 & 0,05 & $-7,84$ \\
\hline P13 & 5,61 & 0,38 & 0,02 & 0,12 & 0,01 & 0,42 & 0,02 & 0,06 & 0,00 & 0 & 0,00 & 0,41 & 0,01 & 0,00 & 0,00 & 0 & 0,00 & 0 & 0,00 & 2,78 & 0,05 & 0,06 & 5,27 & 0,05 & $-7,97$ \\
\hline P14 & 5,59 & 0,45 & 0,02 & 0,18 & 0,01 & 0,43 & 0,02 & 0,05 & 0,00 & 0 & 0,00 & 0,42 & 0,01 & 0,00 & 0,00 & 0 & 0,00 & 0,22 & 0,00 & 2,59 & 0,04 & 0,06 & 5,84 & 0,06 & $-1,51$ \\
\hline $\mathbf{P 1 5}$ & 6,60 & 2,47 & 0,12 & 0,15 & 0,01 & 0,50 & 0,02 & 0,06 & 0,00 & 0 & 0,00 & 0,38 & 0,01 & 0,00 & 0,00 & 0 & 0,00 & 0,88 & 0,02 & 7,49 & 0,12 & 0,15 & 15,93 & 0,16 & 2,32 \\
\hline P16 & 6,00 & 1,89 & 0,09 & 0,17 & 0,01 & 0,50 & 0,02 & 0,08 & 0,00 & 0 & 0,00 & 0,73 & 0,02 & 0,16 & 0,00 & 0 & 0,00 & 0,56 & 0,01 & 5,42 & 0,09 & 0,12 & 12,40 & 0,13 & 3,28 \\
\hline P17 & 5,8 & 10,6 & 0,08 & 0,28 & 0,02 & 0 & 0 & 0 & 0 & 0 & 0 & 0,86 & 0,02 & 0,55 & 0,01 & 0 & 0 & 0 & 0 & 4,66 & 0,08 & 0,11 & 11,5 & 0,11 & 0,00 \\
\hline
\end{tabular}

E.P: Erro Prático 